\title{
CLIMATE CHANGE INFLUENCE ON A FORESTED URBAN PARK: A FORECAST OF TREE GROWTH AND MORTALITY
}

\author{
By \\ Geet Kanwal S. Grewal, \\ Bachelor of Science, \\ University of Toronto, 2010
}

\author{
A thesis \\ presented to Ryerson University \\ in partial fulfillment of the \\ requirements for the degree of \\ Master of Applied Science \\ in the Program of \\ Environmental Applied Science and Management \\ Toronto, Ontario, Canada, 2013 \\ (c) Geet Kanwal Grewal, 2013
}




\section{Author's Declaration}

I hereby declare that I am the sole author of this thesis. This is a true copy of the thesis, including any required final revisions, as accepted by my examiners.

I authorize Ryerson University to lend this thesis to other institutions or individuals for the purpose of scholarly research.

I further authorize Ryerson University to reproduce this thesis by photocopying or by other means, in total or in part, at the request of other institutions or individuals for the purpose of scholarly research.

I understand that my thesis may be made electronically available to the public. 
Climate change influence on a forested urban park: A forecast of tree growth and mortality

Master of Applied Science, 2013

Geet Kanwal Grewal

Environmental Applied Science and Management, Ryerson University

\begin{abstract}
Climate change is expected to lengthen the growing season for plants in many temperate regions. The purpose of this study is to develop future growth estimates for trees in Earlscourt Park, Toronto. The i-Tree Forecast model, in combination with climate change scenarios provided by the Canadian Climate Change Scenario Network, were used to build trajectories of future tree growth and mortality. Tree growth forecasts were greatest for the climate change scenario with the longest growing season length. Results highlight future vulnerability in two tree species common to the park, honey locust and Norway maple. A comparison of the leaf area estimates produced by i-Tree Streets and iTree Eco was also conducted. These models showed differences in their prediction of leaf area, a key metric for ecological service provision. Forecasting tree growth and mortality in urban parks can inform management plans that seek to maximize the flow of future ecological benefits.
\end{abstract}

Keywords: tree growth, tree mortality, i-Tree Eco, i-Tree Forecast, i-Tree Streets, growing season length, urban park sustainability, management plan 


\section{Acknowledgments}

Foremost, I would like to thank my advisor Dr. Andrew Millward for his tremendous support, guidance, and supervision throughout the Master of Environmental Applied Science and Management program. He supported me throughout all phases of this thesis, including inception, field data collection, statistical analysis, and editing. Furthermore, I would like to express my gratitude toward Dr. David Nowak and Alexis Ellis of the USDA Forest Service who dedicated their time and expertise in the design phase and results generation of this study, by allowing this project to be a pilot in their new i-Tree tool. Also, thanks to my fellow students and colleagues, Shawn Mayhew-Hammond, Michelle Blake, Vadim Sabetski, and William Davis (all members of Ryerson's Urban Forest Research \& Ecological Disturbance Group) for their resourcefulness and valuable assistance in data collection, processing, reviewing and brainstorming. I would like to thank my parents for their unconditional love and support throughout this venture. 


\section{Table of Contents}

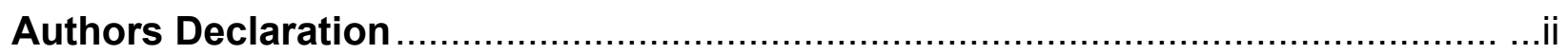

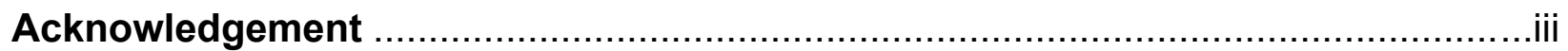

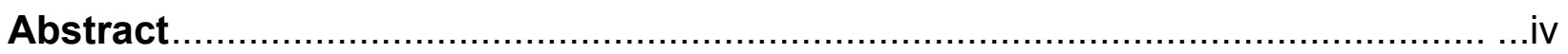

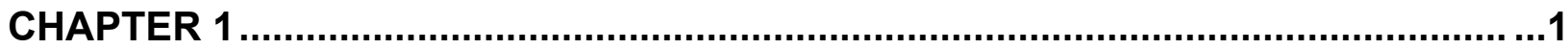

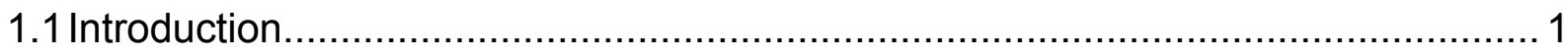

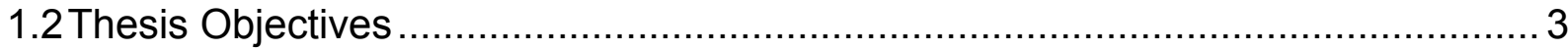

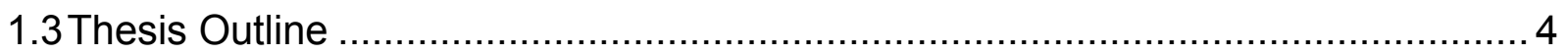

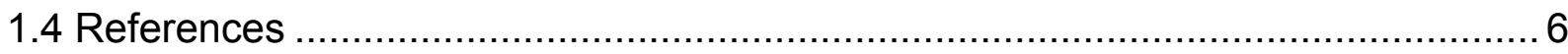

CHAPTER 2

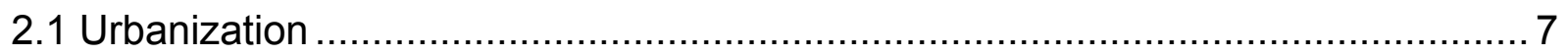

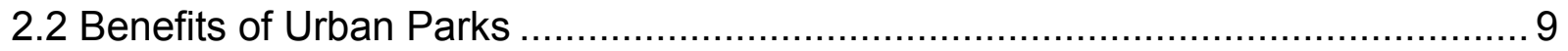

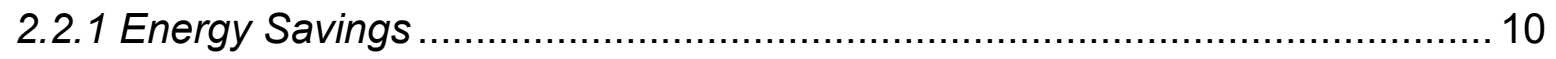

2.2.2 Carbon Sequestration \& Air Pollution...................................................... 12

2.2.3 Stormwater Runoff \& Hydrological Improvements .................................... 14

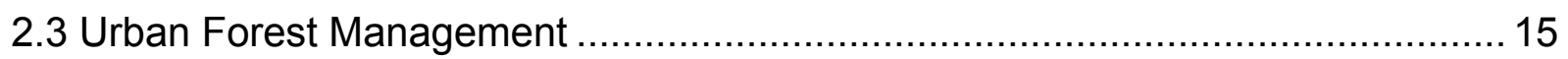

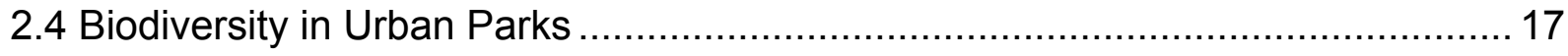

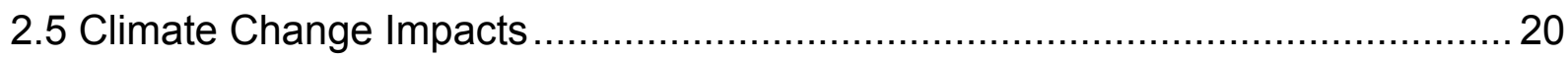

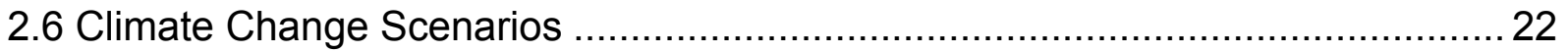

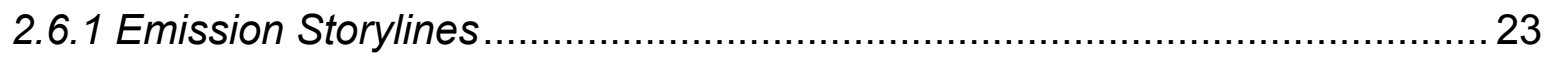

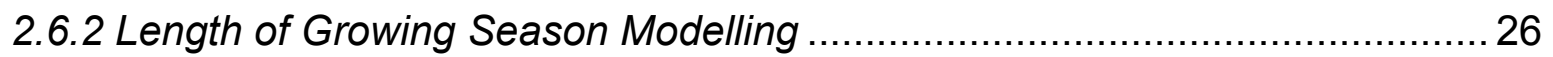




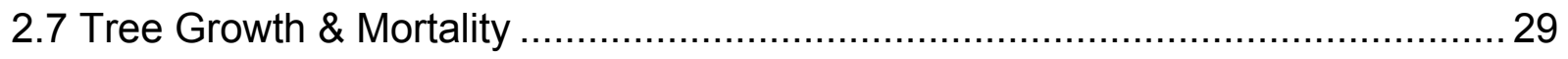

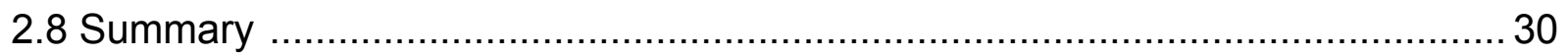

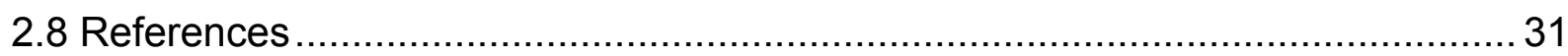

CHAPTER 3

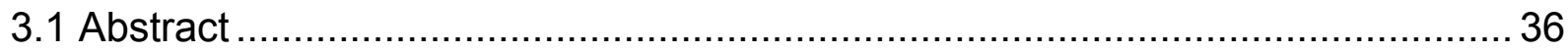

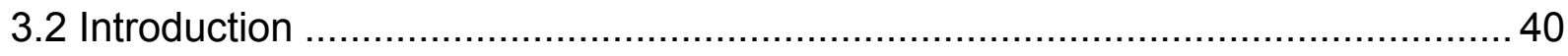

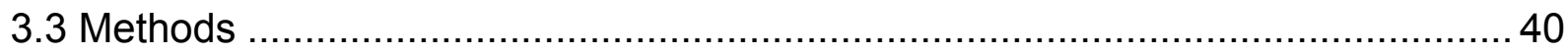

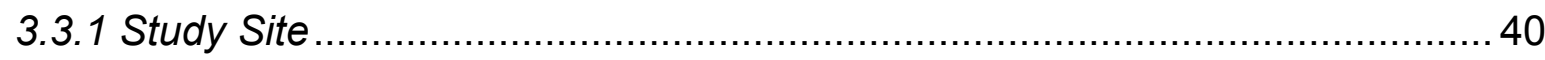

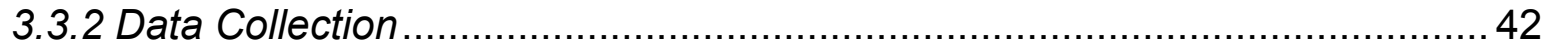

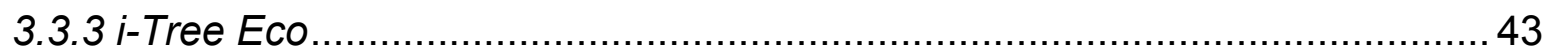

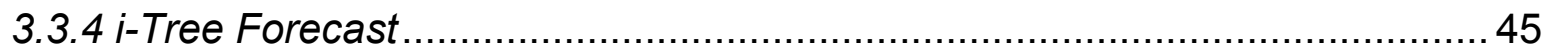

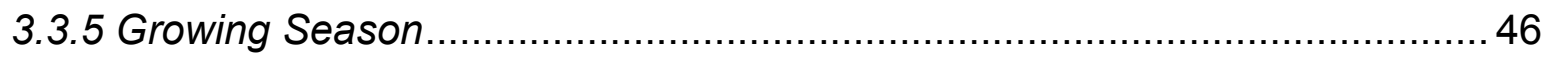

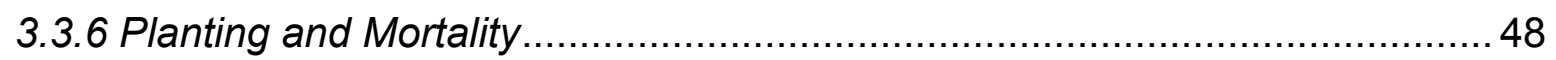

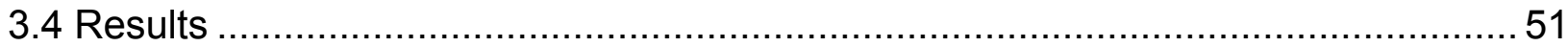

3.4.1 Current Structure and Ecological Services ........................................... 51

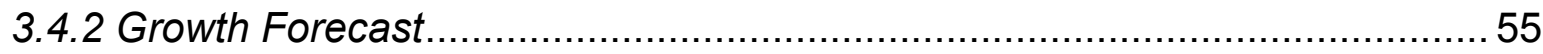

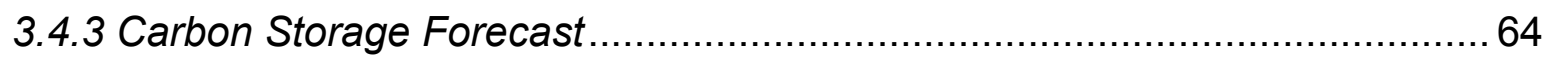

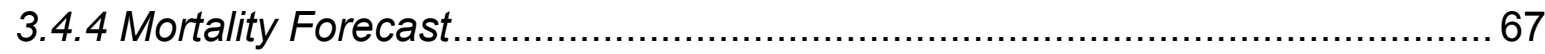

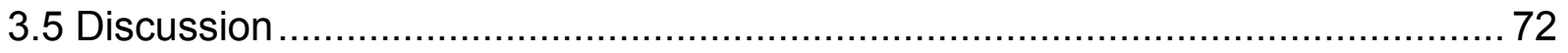

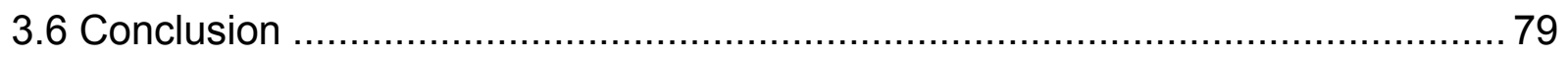

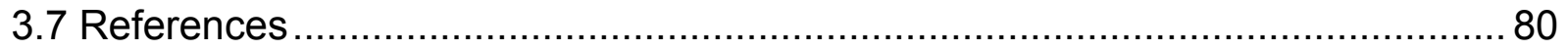

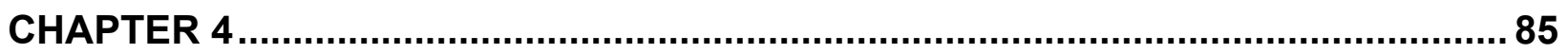

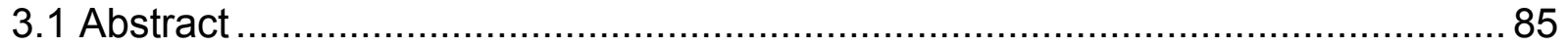




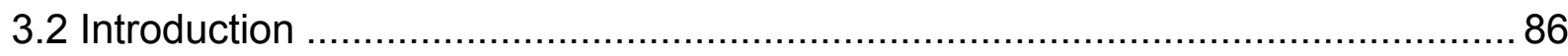

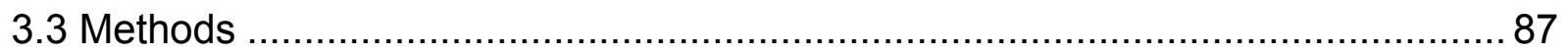

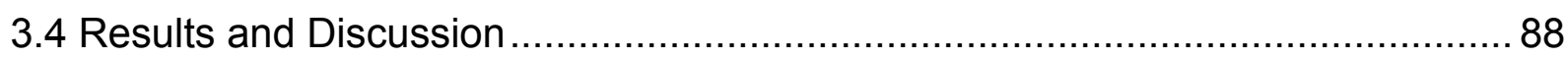

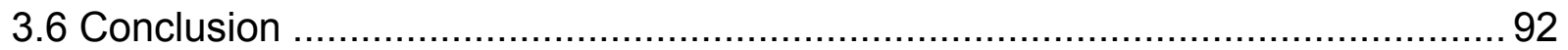

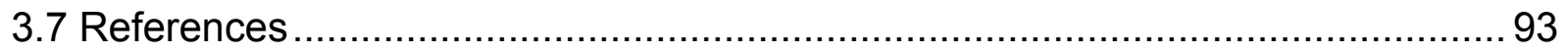

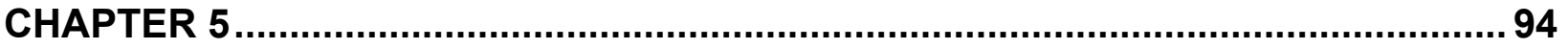

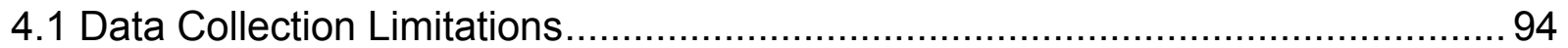

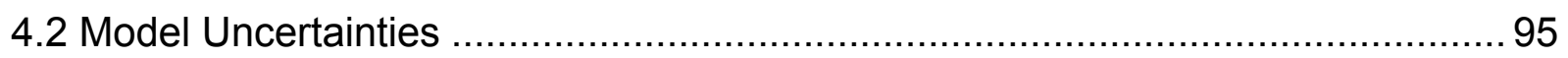

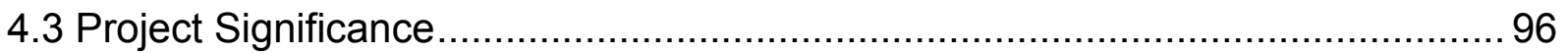

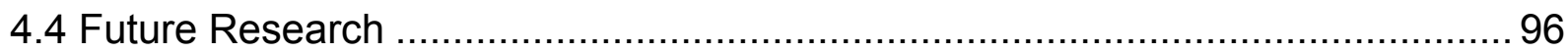

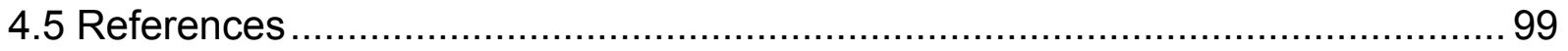

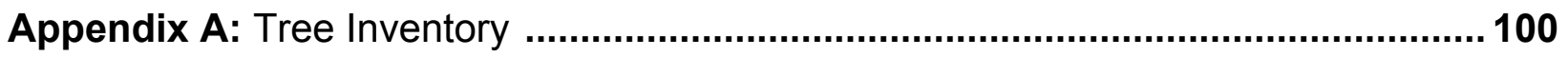

Appendix B: Individual Tree Characteristic Results (Eco) ........................................ 128

Appendix C: Species Characteristic Results (Eco)_................................................. 145

Appendix D: Leaf Area Comparison (Eco and Streets) ….......................................... 147

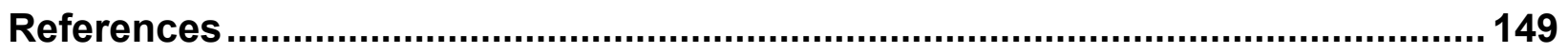




\section{List of Tables}

Table 3.1: Length of Growing Season (GFDLCM, NCARPCM, MIROC) ....................... 47

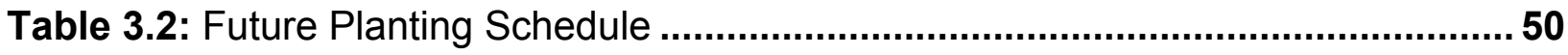

Table 3.3: Tree Species Characteristics (Eco) ......................................................53 


\section{List of Figures}

Figure 3.1: Aerial Map of the Study Area ................................................................... 40

Figure 3.2: Average DBH of the Population ............................................................57

Figure 3.3: Leaf Area Projections (Norway maple) ...................................................58

Figure 3.4: Leaf Area Projections (Little-leaf linden) ...................................................60

Figure 3.5: Leaf Area Projections (Honey locust) ...................................................... 61

Figure 3.6: Leaf Area Comparison for 2018 with and without new plantings ................ 63

Figure 3.7: Carbon Storage Projections (Norway maple) ….........................................65

Figure 3.8: Carbon Storage Projections (Little-leaf linder) .........................................6 66

Figure 3.9: Carbon Storage Projections (Honey locust)................................................68

Figure 3.10: Population Survival Rate Projections ......................................................69

Figure 3.11 Projection Survival Rate Comparison ..................................................... 71

Figure 4.1: Eco and Streets Leaf Area Comparison .................................................. 89

Figure 4.2: Eco and Streets Leaf Area Correlation Scatterplot .................................... 91 


\section{Chapter 1}

\subsection{Introduction}

Urban park trees play a role in delivering ecological services to communities and are instrumental in mitigating the harmful effects of air pollution, elevated summer temperatures and storm water runoff (Akbari et al., 2001; Grapentine, 2009; Nowak, 1994). Healthy public trees also provide important aesthetic improvements to cities that translate into economic benefits (e.g., increased desirability of homes and retail locations) (Millward \& Sabir, 2010). It is important to understand the current ecological value provided by individual trees and specific species of trees present within urban parks, so as to assist with future planning and management of urban treed spaces and to ensure that tree benefits continue into the future. Therefore, it is critical to evaluate urban forests, not only for the current benefits that they provide to the communities, but also for their future functions and services. To date, most parks and urban forest management approaches are based on present (or near present) conditions.

The ecological benefits of trees are heavily dependent on tree size, where significant correlation between urban tree age and size are documented in the literature (Peper et al., 2003). With additional knowledge of growth and mortality rates, future benefits of urban forest trees can be estimated (Lawrence et al., 2012). Tree growth curves can play an important role in best management practices for city trees. Trees deliver greater benefits when their leaf area (LA) and canopy volume are larger, which are characteristics of older trees with larger diameter at breast height (DBH) values (Peper et al., 2001). However, with age and pest infestation, there will be a point in the future when these large trees die 
and the enhanced benefits they provide will be lost. Hence, management strategies need to be in place in anticipation of the need to replace trees in future. Such management strategies, however, should not be solely based on the concept of replanting for numbers. Instead, knowledge of the ecological benefits provided by particular species is critical to future-oriented best management practices. The ability, through modeling, to forecast future estimates of the ecological benefits delivered by individual trees and tree species will move urban forest management to this next level.

Information about the ecological benefits delivered by trees based on their size and species can play a major role in understanding, maintaining, and even enhancing urban forest biodiversity. Together, growth and mortality curves in association with a quantification of the ecological benefits park trees deliver can help to predict which species may be the first to diminish in numbers and what this will translate into regarding lost benefits. The present study seeks to capture this type of information by conducting a tree growth and benefit assessment. This information can then be used to select species to be planted based on their unique growth requirements, where the health and vigour of urban trees is primarily influenced by environmental conditions. Therefore, it is important to incorporate variations in the environment that may occur in the future.

Environmental conditions, such as temperature and air quality, can play a significant role in tree growth and mortality (McPherson et al., 2005). Environmental variability, most notably the effects of climate change, will also play an important part in decisions made by policy makers (Nowak et al., 2004). Information about how urban tree benefits will change, not only with time but also 
with varying environmental conditions, can impact the choices made by planners regarding investment in public trees such as number and species to plant, when to plant, selection of planting locations, and determining the frequency of planting and maintenance efforts. This information may also help community groups and nongovernmental organizations with similar efforts to plant trees and raise awareness of their benefits.

\subsection{Purpose of the Study}

The purpose of this research is to investigate the present and future occurrence and condition of trees in Earlscourt Park, Toronto. Specifically, the iTree Eco model is used to estimate the present benefits delivered by trees currently growing in the park. These benefits include structural value, pollution avoidance, storm water interception and carbon sequestration. Then, based on knowledge of present tree occurrence and condition, forest structure (e.g., size, species composition) and ecological benefits, the future of the tree population was forecasted through 2040 using three distinct and locally-specific climate change models. As a side project, yet directly related to tree benefits estimation, leaf area estimates generated by two commonly used urban forest benefit estimation models, i-Tree Eco and Streets were compared. i-Tree Streets, as the name suggests, was developed to provide a benefits-to-cost estimation of street trees; however, its popularity, owing greatly to the limited amount of data required to estimate tree benefits, has meant that it is frequently applied in situations without proper consideration of underlying model assumptions. 
In general, this project aims to provide a preview of the Earlscourt tree population on an annual basis through the year 2040. Through the use of several tree mortality rates, three climate change scenarios and the new i-Tree Forecast model, several plausible future tree growth trajectories for Earlscourt Park have been created. Specifically, i-Tree Forecast was used to estimate the change in forest structure and carbon storage capacity. Results of the project offer important insights into what managers of Earlscourt Park may expect under varying climate change and tree replanting scenarios. Along with the overall future condition of park trees, the approach taken in this research provides evidence of how the importance of different tree species change as they grow, mature and die. Finally, in addition to assisting planners and managers in preparing for the future of trees in Earlscourt Park, this research has sought to design a methodology for tree growth and mortality forecasting that is transferable to other treed urban parks.

\subsection{Thesis Outline}

This thesis is organized into five chapters. Taken as a whole, it covers the current condition of Earlscourt Park, Toronto using i-Tree Eco and Street benefits estimation; and, it develops a methodology for analyzing the future trees in the park using a new i-Tree tool, Forecast, in combination with other climate, tree mortality and future planting scenarios. Chapter One provides an introduction to the thesis and explains the purpose and general approach taken in the research. A literature review is presented in the second chapter and covers the topics of tree growth and mortality estimation, urban forest benefits calculation and climate change scenarios that could influence the future of trees in the study park. Chapter 
Three is organized as a standalone manuscript. It has been formatted to meet the submission guidelines of the journal Landscape and Urban Planning. Chapter Four is written in the style of a short research note, to be submitted for publication to Landscape and Urban Planning as well. Specifically, this research note evaluates differences in results generated by the tree benefit estimation tools i-Tree Eco and Streets, using the same data set. The final chapter, Chapter Five, examines the uncertainties in the project, further speculates on significance of the research and presents possible future research directions stemming from findings of this work. 


\subsection{References}

Akbari, H., Pomerantz, M., \& Taha, H. (2001). Cool surfaces and shade trees to reduce energy use and improve air quality in urban areas. Solar Energy 70, no. 3:295-310.

Grapentine, L., Rochfort, Q., \& Marsalek, J. (2008). Assessing urban stormwater toxicity: Methodology evolution from point observations to longitudinal profiling. Water Science and Technology, 57, 1375.

Lawrence, A., B., Francisco J., Escobedo, C., Staudhammer, L. \& Zipperer. W. (2012). Analyzing growth and mortality in a subtropical urban forest ecosystem. Landscape and Urban Planning 104, no. 1:85-94.

McPherson, G., Simpson, J. R., Peper, P. J., Maco, S., \& Xiao, Q. (2005). Municipal forest benefits and costs in five US cities Journal of Forestry, 103(8), 411-416.

Nowak, D. J. (1994). Atmospheric carbon dioxide reduction by Chicago's urban forest. In E. G. McPherson, D. J. Nowak, R. A. Rowntree (Eds.), Chicago's Urban Forest Ecosystem: Results of the Chicago Urban Forest Climate Project (USDA Forest Service General Technical Report NE-186, pp. 83-94), Radnor, PA.

Nowak, D. J., Kuroda, M., \& Crane, D. E. (2004). Tree mortality rates and tree population projections in baltimore, maryland, USA. Urban Forestry \& Urban Greening, 2(3), 139-147.

Peper, P., McPherson, G. \& Mori, S. (2001). Equations for predicting diameter, height, crown width and leaf area of San Joaquin Valley street trees. Journal of Arboriculture 27(4): July 2001 27, no. 4:169.

Peper, P., \& McPherson, G. (2003). Evaluation of four methods for estimating leaf area of isolated trees. Urban Forestry \& Urban Greening 2, no. 1:19-29. 


\section{Chapter 2}

\subsection{Urbanization}

Urbanization is not a new phenomenon; it has increased in rate since the era of industrialization. However, instead of plateauing or even declining in rate, urbanization is now occurring faster than ever. In 2008, the global proportion of people living in urban areas surpassed the proportion of humans living in rural areas (Seto et al., 2010). Technological advancement has lessened the chances of major health epidemics and natural hazards, and has been an important driver of the rate of urbanization. The trend toward urbanization is both demographic (i.e., more people prefer to live in cities than rural areas) and spatial (i.e., cities are occupying larger and larger areas and are having more of an impact on their surrounding environments); urbanization is also occurring in unexpected regions (Seto et al., 2010).

Increase in urban population brings changes to the physical nature of the urban landscape. Higher population density leads to higher demand for housing, and requirements for more commercial and industrial areas (Jansson \& Lindgren, 2012). On the whole, these consequences of urbanization have been, at least partially, responsible for increases in air pollution, warming of the urban microclimate and loss of biodiversity in cities (Gómez-Baggethun \& Barton, 2013). The urbanization process has resulted in dramatic increases in the amount of impermeable surface, which leads to elevated surface runoff and poor management of storm water (Morrison, 2008). Greater densities of traffic caused by urbanization have led to degradation in air quality (e.g., increases in $\mathrm{CO}_{2}, \mathrm{CO}$, $\mathrm{SO}_{2}$ and particulate matter) (McPherson, 1999). Greater expanses of hard surface, 
including asphalt and concrete, have led to a decrease in albedo (reflection of solar radiation), which in turn has contributed to rising urban temperatures and a heightened demand for energy needed to air condition buildings (McKinney, 2006). Urbanization can also cause habitat fragmentation, whereby construction of roads divide natural habitats into smaller and smaller enclaves. This fragmentation process can lead to a higher mortality for certain plant and animal species that require a larger geographic range (McKinney, 2006).

Urban areas have been major contributors to climate change as well. Analysis by Lobo et al. (2004) for US metropolitan cities shows that a $1 \%$ increase in urban population leads to a $0.92 \%$ increase in local $\mathrm{CO}_{2}$ concentrations. Production-based analysis shows that urban areas are responsible for 30 to $40 \%$ of greenhouse gas emissions (Pachauri \& Reisinger, 2007). Adding in consumption-based analysis, increases this range to between $50-60 \%$ of the greenhouse gas emissions (Pachauri \& Reisinger, 2007). Globally, urban areas are also vulnerable to climate change with respect to a rise in sea levels. A rise of 0.8 meters in sea level by the year 2100 has been predicted (Pachauri \& Reisinger, 2007). For many coastal cities with inadequate adaptation strategies, this rise in sea level could be catastrophic.

On the flipside, research has demonstrated important sustainability advantages to urbanization. For example, urbanization has led to an increase in economies for infrastructure development, education, health care and other services (Seto et al., 2010). There is also evidence of an increase in returns to innovation and wealth creation (Seto et al., 2010). If a portion of these benefits were focused on creating positive environmental change, large urban areas could 
then play more of an active role in creating a sustainable future through new technologies and innovative institutional arrangements (Seto et al., 2010). Such interacting dynamics have the potential to benefit pursuit of sustainability for current and future urban populations. From the perspective of public vegetation in cities, Alvey (2006) argues that this new era of urbanization could give birth to a new phase of planning for sustainability, which could greatly enhance initiatives oriented at managed growth of urban parks.

\subsection{Benefits of Urban Forests}

McPherson (2006) defines urban forestry as, "planning and management of trees, forests and related vegetation within the communities to add value". The four major sections of urban forestry that are currently being studied in the literature include economic, ecological and social benefits, as well as urban forest policy (McLean et al., 2007). Economic benefits refer to the study of how urban trees impact the economy of an area. Ecological benefits are the environmental services delivered by trees that benefit urban inhabitants (e.g., improved air quality, summer temperature moderation, storm water management). More recently, these ecological benefits have been monetized (McPherson et al., 2006). Social benefits constitute the provision of aesthetics and related public perceptions of city trees and the urban forest. Urban forest policy deals with research concerning management strategy focused on protection and enhancement of urban forests.

Urban park trees play a major part in delivering services to the communities in which they grow, especially as these services relate to mitigating the harmful effects of urbanization. Some examples of these services include carbon 
sequestration, air pollution abatement, storm water management, summer temperature moderation, electricity conservation and enhanced urban aesthetics (Nowak, 1994; Akbari et al., 2001; Grapentine, Nowak \& Crane, 2002; 2008;

Sawka et al, 2012). A recent study by Millward and Sabir (2011) demonstrated that a treed urban park can have as high as a 3.4:1 benefit-to-cost ratio when considering both the environmental and economic benefits of park trees. The value of these treed urban park benefits only stands to rise in the future, as more people migrate from rural to urban areas. Furthermore, it is important to understand the unique species-specific ecological value provided by individual park trees when designing future urban forest planning and management strategies.

\subsubsection{Energy Savings}

In modern cities, economics often takes precedence over most matters, and this view extends into the field of urban forestry. Urban forests provide important economic savings in the form of energy conservation. Traditional building materials are poor heat insulators. Hence, during daylight hours, they absorb and conduct heat across and through their built surfaces; this high thermal capacity causes warming of interior temperatures and a consequent increase in demand for cooling energy (McPherson et al., 2006). Analysis of temperature trends in several US cities shows an increase of 0.5 to $3^{\circ} \mathrm{C}$ since the 1940s (Akbari et al., 2001). Electricity demand has been demonstrated by Akbari et al. (2001) to increase by 2$4 \%$ for every Celsius degree of increase in temperature. In downtown Los Angeles, 
for example, a $2.5^{\circ} \mathrm{C}$ rise in temperature since 1920 has led to an increase in energy consumption of $1500 \mathrm{MW}$ (Akbari et al., 2001).

Research has also shown that urban heat island mitigation strategies, including promoting tree cover, could lower US national energy demand for air conditioning by $20 \%$, in turn saving over $\$ 10$ billion and at the same time improving urban air quality (Akbari et al., 2001). Green roofs, urban trees and vine-covered walls are all examples of urban heat island strategies that rely on vegetation. Previous research has shown that strategically planted urban trees can lower the temperature of the surrounding area by $3^{\circ} \mathrm{C}$ (Akbari et al., 1992). More recent research has shown that, depending on the species, size and placement of urban trees around buildings, energy demand for air conditioning can be lowered by 10 to $90 \%$ (Nikoofard et al., 2011). This range of reduced energy demand is so wide because orientation to a building and canopy characteristics of shade trees vary greatly in their combined influence on shading and evapotranspirative cooling (Nikoofard et al., 2011).

Building energy simulations can include external impacts, such as the shading influence of urban trees; such simulations focus on the efficiency of trees to conserve energy based on tree size, species and planting location. However, in densely built urban areas, Sawka et al. (2013) argue that survivorship should be the first priority over strategic planting, even when the planting goal is to conserve electricity. This is because trees that reach maturity have the potential to shade multiple buildings at varying orientations. Sawka et al. (2013) found that trees planted between the years 1997 and 2000 provide average energy conservation 
benefits of $167 \mathrm{kWh} /$ tree as of the year 2009. These conservation benefits were estimated to rise to anywhere between 435 to $463 \mathrm{kWh} /$ tree in the next 25 years (Sawka et al., 2013). Urban trees also provide energy conservation benefits during the winter. By planting evergreen trees like cedar, pine and spruce in an orientation from a home that blocks wind, trees can be effective wind barriers, which can help buildings to preserve heat through decreasing air infiltration by up to $50 \%$ during the winter (McPherson et al., 2006).

The importance of energy conservation benefits will rise proportionally with an increase in urban population as well as with the ever-increasing costs of energy. More people in small areas, and rising energy costs, are likely to lead to an increase in attention toward maintenance and planting large canopy trees, green roofs and other urban vegetation strategies, in pursuit of methods to moderate future demand for energy. In a study of Toronto, Akbari \& Konopacki (2004) showed that strategic tree planting, with the aim of increasing shade and provision of wind barriers, can lead to an annual peak power avoidance of $250 \mathrm{MW}$ and an city-wide annual electricity savings of $150 \mathrm{GWH}$.

\subsubsection{Carbon Sequestration and Air Pollution}

Carbon storage is defined as the carbon currently held in the biomass of a tree, some of which can be released into the atmosphere on the death of the tree. Carbon sequestration is the carbon that has been removed from the atmosphere, usually reported annually, and which becomes incorporated into plant biomass until which time the tree dies. Plants are well known for their ability to capture $\mathrm{CO}_{2}$ and sequester it in the form of woody biomass (Nowak \& Crane, 2002). Urban trees 
have been shown to have the capacity to sequester large amounts of $\mathrm{CO}_{2}$ and act as carbon sinks (Nowak \& Crane, 2002). An evaluation of data from 10 cities in the Unites States showed that trees have the capacity to sequester 658 million tonnes of carbon annually (Nowak et al., 2012). A study of Allan Gardens, an urban park in Toronto, showed that the park reduced annual atmospheric $\mathrm{CO}_{2}$ by $51,895 \mathrm{~kg}$, valued at $\$ 858 /$ year (Millward \& Sabir, 2011). Urban trees can also impact release of $\mathrm{CO}_{2}$ through their energy shading and evapotranspirative cooling benefits. Less demand for electricity translates into less release of $\mathrm{CO}_{2}$ (Nowak et al., 2012). Understanding this benefit of urban trees can assist in preparing more detailed GHG (greenhouse gas) inventories (Nowak \& Walton, 2005).

Air pollution can impose serious risks to human health, as observed around the world in regions with poor air quality (Nowak, 1994). Trees ameliorate air pollution by absorbing pollutants such as nitrogen dioxide $\left(\mathrm{NO}_{2}\right)$, carbon monoxide (CO) and ozone $\left(\mathrm{O}_{3}\right)$. Trees also serve to reduce particulate matter in the air by intercepting particulates via their broad leaves (Chen \& Jim, 2008). Trees also release oxygen into the atmosphere through the process of photosynthesis, which can further improve the quality of the urban atmosphere. Some pollutants, like $\mathrm{SO}_{2}$ and $\mathrm{NO}_{2}$, can react with water found in the inner leaf cells to form sulphuric, sulphurous, nitric and nitrous acids (Chen \& Jim 2008). These acids are transferred into other plant cells and are eventually assimilated and fixed within the plant tissue.

A study by Millward and Sabir (2011) estimated that in the year 2008, 133kg of $\mathrm{O}_{3}, \mathrm{NO}_{2}, \mathrm{PM} 10$ and $\mathrm{SO}_{2}$ was either absorbed or intercepted by trees growing in Allan Gardens, a large downtown urban park located in the City of Toronto; this 
study valued these air pollution abatement benefits at $\$ 1520$ for 2008 . The effectiveness of pollution removal services provided by trees is dependent on many factors such as aerodynamic roughness, atmospheric stability, pollution concentration, solar radiation, temperature, wind velocity and turbulence, particle size, and gaseous chemical activity and solubility (Nowak, 1994). Many of these factors are considered in urban forest benefit estimation models, such as i-Tree Eco.

\subsubsection{Storm Water Run-off Reduction and Hydrological Improvement}

Surface runoff is a major urban issue, since it can cause a significant amount of damage in the form of flooding and pollution of water bodies proximate to cities (Grapentine, 2008). Storm water runoff disturbs the set thermal regimes in rivers and lakes and also impacts the sediment regime. Because storm water usually carries a high degree of pollutants from roads and combined sewage-storm drain effluent, aquatic habitat is often heavily impacted around cities following major rain events (Grapentine, 2008). These impacts then trickle down to influence larger downstream bodies of water. The presence of city trees plays an important role in mitigating these negative effects of surface water runoff. Tree canopies, larger ones being much more effective, intercept water before it reaches the ground; they also have a great capacity to store large quantities of water in their leaves, stems and roots (Grapentine, 2008). In addition to the canopy, root growth and decomposition also reduce surface water runoff by providing channels for water to percolate into the ground and be absorbed by the soil (McPherson et al., 2006). The combination of these two processes decreases the surface runoff 
which, when many trees are present, can dramatically lower the chances of flash floods and other storm water-related damage. As with other tree benefits, the storm water management benefits of trees can be quantified and, where healthy urban forests exist, make an important contribution to reducing infrastructure costs.

When rain falls onto tree canopies, it takes one of two routes to reach the ground surface. In one route, water either reaches the understory soil by falling through the canopy uninterrupted or by dripping off the leaves. In a second route, it is intercepted by leaves and branches, and is directed toward the bole of the tree. Rainwater that is intercepted and remains on the leaf surface will eventually evaporate into the atmosphere (McPherson et al., 2006). Trees with large leaf areas provide significant temporary storage for rainwater and thus serve to decrease surface runoff following precipitation events (McPherson et al., 2006). Rainwater that is redirected from the leaves to the branches and main stem of the tree slowly makes its way to the understory soil, thus reducing the rate of downward movement of water and thereby decreasing the chances of flash floods. In 2008, the urban canopy of Toronto's Allan Gardens park intercepted $1920 \mathrm{~m}^{3}$ of rainwater (Millward \& Sabir, 2011). This intercepted volume of water was valued at $\$ 3701$, which represents public money that did not need to be spent on storm water processing at sewage treatment plants.

\subsection{Urban Forest Management}

As with any environmental resource, management plays a key role in ensuring benefits and maintaining the sustainability of the resource. However, organization plays a vital role in effectiveness of management. Good management 
requires strategic thinking based on analysis and long-term planning done on a tactical level. Morgan (1991) asked for a strategic approach to manage parks and urban spaces, which included analysis, plans, surveys, monitoring and reviews. Randrup \& Persson (2005) took an organizational approach to management of urban parks by creating a three-step model that includes: (a) political, where policies are made; (b) tactical, where plans are produced; and, (c) operational, where field operations are carried out. Their model is based on the fact that management, which is largely operational, will have problems implementing longterm goals with the eventual consequence of park degradation (Randrup \& Persson, 2009).

Although efforts have been made to design such management schemes, that look far into the future with both short term and long term goals (Kenney et al., 2010), few studies have been undertaken with a view toward forecasting future benefits provided by urban forests. Nonetheless, the City of Toronto has completed an inventory and has instigated policies that seek to increase the city's urban tree canopy from approximately $20 \%$ at present to 30 to $40 \%$ by the year 2050 (City of Toronto, 2013). Forecasting the future services delivered by an urban forest requires careful consideration of the growth characteristics of existing trees, mortality rates, and how each of these interplay with a changing climate. A comprehensive study of this nature has not been done for an urban forest. Predicting how an urban forest may evolve and change under future climate scenarios will be of great benefit to a city when it comes to establishing planning and management goals. 
An application of i-Tree STRATUM (now Streets) was used by Millward and Sabir (2011) to estimate the ecological benefits provided by park trees in Allan Gardens, Toronto. These authors highlighted the importance of forest structure from the perspective of tree age, species richness and canopy leaf area. Together, these three urban forest structural components play a significant role in the present flow of ecological services, as well as informing management so as to ensure that the delivery of these benefits continues into the future (Sawka et al., 2013).

Urban forest growth models based on the Age-DBH relationship have been created for many US cities, and are cited in the literature (Peper et al., 2001b). More recently, the importance of mortality modelling has been considered a crucial component concerning the future management of urban trees. Work on urban forest mortality has been conducted in the United States by Lawrence et al (2012), who showed that variability in tree mortality is based on many factors beyond tree species (e.g., maintenance activities, site conditions, soil properties, tree characteristics, and land use land cover). Minimum, maximum and average mortality rates for trees growing on Toronto's residential property were used in a study by Sawka et al. (2013), where a minimum rate was specified as $0.7 \%$, a maximum at $1.5 \%$, and an average rate of $1.1 \%$. Having several mortality scenarios with a forecasting model is valuable for discussion when developing future urban forest management plans.

\subsection{Biodiversity in Urban Parks}

The importance of biodiversity in urban tree species is well known, and in North America dates back to the infestation of elm trees by the Dutch elm disease 
(DED) in the mid $20^{\text {th }}$ century (Alvey, 2006). Biodiversity has various benefits (that will be covered later in this section); however, current trends show a significant loss of urban tree biodiversity across the world (Alvey, 2006). Factors contributing to this loss in biodiversity are habitat modification, landscape fragmentation, rapid environmental and climate changes, and competition from introduced species (Groombridge and Jenkins, 2002). Urban forests can contain relatively high levels of biodiversity (Alvey, 2006). In the USA, an average of $25 \%$ tree canopy cover is found in urban counties (Dwyer et al., 2000). With future increases in urbanization projected, the size and value of urban forests are under threat (Nowak \& Walton, 2005). Recent studies have shown the ability of urban and sub-urban regions to be biologically rich (Alvey, 2006). In the large city of Guangzhou, China, Jim \& Liu (2001) found 250 tree species in a survey of 115,000 . In fact, these authors report that they found more species in the city when compared with surrounding degraded peri-urban forests. Urban green areas are also home to endangered plant species. For example, some species on the Swedish red list of endangered species are found in the urban forests of Stockholm County (Alvey, 2006).

As mentioned earlier, urban trees provide a variety of ecological benefits. However, these benefits are greater for trees with larger canopies (Nowak, 1994). Although the quantity of benefits delivered is directly related to the canopy size, the specifics of benefits varies from one tree species to another. In other words, two species with the same canopy size might deliver different ecological benefits. One species might perform best for carbon sequestration whereas another may be better suited to storm water interception. In the Toronto urban park, Allan Gardens, Norway maple (Acer Platanoids) was the most effective tree species at intercepting 
and absorbing air pollutants (Millward \& Sabir, 2011). However, in terms of storm water mitigation, black walnut (Juglans nigra) was most effective (Millward \& Sabir, 2011). Since urban environments are changing rapidly, the ideal way to adapt to these changes is by increasing the species diversity within the urban tree population.

One important advantage of species biodiversity is the protection of urban forests from pest infestation. Historically, Toronto and other North American cities witnessed the carnage brought by DED to vast populations of urban elm trees. At present, many eastern North American cities are poised to lose large portions of their ash tree populations due to the emerald ash borer (EAB). In fact, the City of Toronto projects a complete loss of ash species by the year 2017 (City of Toronto, 2013). In cases of such infestations, species biodiversity plays a key role at buffering impacts. When the overall population is dominated by few species, major ecological impacts can occur if that species becomes vulnerable to a pest infestation. Millward \& Sabir (2011) caution that Allan Gardens' dominance by maple species (Acer spp.) also places it in a vulnerable position.

A major challenge facing the attainment of higher biodiversity across many urban forests is biotic homogenization. It is defined as the process of replacing local species with invasive, non-native species (McKinney, 2006). Due to a lack of natural enemies, the exotic species can thrive and outcompete the native species (Alvey, 2006). Urban environments are ideal for biotic homogenization due to the constant flux of biota in and out of the city; non-native species are easily spread throughout urban ecosystems (Tait et al., 2005). A phenomenon such as the urban heat island effect can further boost the growth of species that prefer warmer 
temperatures (McKinney, 2006). Therefore, planning that seeks to manage the process of biotic homogenization is a vital component of improving biodiversity in many urban forests.

\subsection{Climate Change Impact}

The combination of human activities and natural events (high winds, floods, ice storms, droughts) are leading to a change in the urban forest landscape. This in turn influences the direction of urban landscape management and the flow of benefits from urban forests (Dwyer et al., 2000). Measured increases in global air and ocean temperature, rising global sea levels and the widespread melting of snow and ice has left little doubt about the existence of global warming (Pachauri \& Reisinger, 2007). Terrestrial systems on all continents are being impacted by regional climate changes, and the rate of change may be accelerating. These system changes are consistent with global warming projections (Pachauri \& Reisinger, 2007).

In ocean systems, an increase in the acidity of ocean surface water has been observed. This effect coincides with the increase in ocean uptake of anthropogenic $\mathrm{CO}_{2}$ since the 1750s (Pachauri \& Reisinger, 2007). Total global annual anthropogenic GHG emissions have increased by 70\% between 1970 and 2004 (Pachauri \& Reisinger, 2007). This has led to an increase in $\mathrm{N}_{2} \mathrm{O}, \mathrm{CH}_{3}$ and $\mathrm{CO}_{2}$ levels, which are exceeding the natural range of the past 650,000 years (Pachauri \& Reisinger, 2007). Based on the Intergovernmental Panel for Climate Change (IPCC) reports, for the next 2 decades, a warming of around 0.2 degrees per decade is expected to occur based on a variety of emission scenarios. In all 
the scenarios, land warms more than oceans in the regions that are adjacent to oceans and land warms more in higher latitudes as well (Pachauri \& Reisinger, 2007). Most importantly, the IPCC report shows a high confidence that recent warming is impacting terrestrial biological systems. Early timing of spring events, such as early leaf-unfolding, bird migration and egg laying, are some examples of the impacts of climate warming on terrestrial biological systems. Satellite imagery has shown a trend towards early greening of vegetation in spring due to longer thermal growing seasons (Pachauri \& Reisinger, 2007).

Short-term natural events can also leave a large and lasting impacts on urban forests. Extreme temperature and precipitation both affect the growth, survival and development of urban forests (Dwyer et al., 2000). By planting species that are tolerant of extreme conditions, the influence of these natural forces can be reduced (Dwyer et al., 2000). In addition to extreme temperatures and precipitation, intensity and frequency of storms (high winds, tornadoes, and ice storms) can also damage urban forests (Dwyer et al., 2000). Tactical management of planted species and new location management can play a role in protecting urban forests from intense storms (Dwyer et al., 2000).

Climate-Species-Matrix is a tool that was developed to select tree species for urban habitats with a consideration of climate change (Roloff et al., 2009). The matrix works on hardiness and drought tolerance, which allows for the selection of a tree species most suitable for climate and location (Roloff et al., 2009). The matrix shows the importance of creating policies and tactical management towards the growth and development of the urban forest mentioned by Randrup \& Persson (2005). Understanding the growth response of trees to climate change is a 
scientific approach to predicting species suitability to changing climate for a particular region. For example, beech tree research has shown reduction in growth in areas with high temperatures combined with low rates of precipitation. However, results also showed a quick recovery in beech trees after years of droughts in medium to high altitude regions (Roloff et al., 2009).

\subsection{Climate Change Scenarios}

New policies and management plans are already in place in many cities to combat the impact of climate change on urban forests (Randrup \& Persson, 2009). However, climate change comes with a lot of uncertainties, most of which are dependent on anthropogenic actions. For example, greenhouse gas and aerosol emissions are now being linked to alterations in temperature, precipitation and frequency of extreme weather events (Pachauri \& Reisinger, 2007). In consideration of the importance of anthropogenic emissions to climate change, the IPCC has developed various emission scenarios to cover all major driving forces of emissions; they have become the basis of majority of climate change projections (Girod et al., 2009). These emission scenarios incorporate a set of different future developments that could occur and result in the alteration of carbon sinks and sources (Nakicenovic et al., 2000). These developments could include a change in energy systems, or something more elementary such as land use change (Nakicenovic et al., 2000). With all of the uncertainties attached to climate change, emissions are now believed to be the greatest driver (Nakicenovic et al., 2000).

Emission scenarios from the IPCC are developed based on various factors. Socio-economics, energy usage, industrial health and population growth are the major factors that affect the construction of these emission scenarios (Nakicenovic 
et al., 2000). Due to the large range of future emission possibilities, infinite future scenarios are possible. Taking this into account, IPCC scenarios cover a finite but wide spectrum of future scenarios (Nakicenovic et al., 2000). In order to efficiently describe these scenarios, IPCC decided to create narrative storylines, which cover all the driving factors for emissions (Nakicenovic et al., 2000). There are four storylines, each based on a combination of the primary driving factors. The driving factors, as outlined in Nakicenovic et al. (2000), for each of the storylines are:

- Demographic developments in relation to other factors

- Economic globalization and social and cultural interactions

- Rate of regional and global economic development

- Rate and direction of global and regional technology

- Rate and direction of environmental concern based development

- Degree of global access to human and natural resources for development

- Balance among economic, environmental, technological and social objectives

\subsubsection{Emission Storylines}

The first storyline covered is A1. This storyline is based on rapid and successful economic development (Girod et al., 2009). The storyline depicts a convergence of per capita income to dissolve the gap between rich and poor countries (Nakicenovic et al., 2000). Strong commitment to market-based solutions is a key part of this storyline. The storyline depends on a commitment to savings and education at a local household level (Nakicenovic et al., 2000). On a national 
and international level, the storyline seeks high levels of investment and innovation in education, technology and institutions. The storyline also predicts movement of people, ideas and technology at an international level (Girod et al., 2009). The economic convergence is generated from advances in transportation and communication technology and a change in national policies on immigration and education (Nakicenovic et al., 2000). Mortality and fertility rates are low in this storyline due to economic growth and stability. The world population rises to 9 billion by the year 2050 and drops to 7 billion by the year 2100 (Nakicenovic et al., 2000). The storyline also shows an abundance of energy and mineral resources due to progress in technology. Because numerous energy and mineral resource usage patterns are possible, various climate change scenarios have been created based on the A1 storyline (Girod et al., 2009). These scenarios are based on conventional sources of energy, new innovative energy sources, or a combination of innovation and conventional resources (Nakicenovic et al., 2000).

The A2 storyline portrays a different world in comparison to A1. In the A2 storyline, trade flows are low along with slower technological changes and slow turnover of capital stock (Nakicenovic et al., 2000). The storyline predicts that the world will get consolidated into economic regions. Self-reliance would be the common trait for nations with a lack of emphasis on economic, social and cultural interactions between regions (Girod et al., 2009). The lack of interaction will lead to technological advances infusing across the world at a slow pace. Economic growth is uneven and the gap between per capita incomes across the world does not converge (Nakicenovic et al., 2000). With the emphasis on family and community life, fertility rates drop slowly, leading to a larger population in comparison to other 
storylines and it predicts a population of 15 billion by the year 2100 (Nakicenovic et al., 2000). The high population indicates that most of the technological advances are focused on increasing agricultural outputs. Attention to environmental concerns is not uniform across all regions; some regions and countries place high priority where as others put very low importance on environmental issues. However, attempts are made to bring local and regional environment issues under control in order to protect vital natural resources (Nakicenovic et al., 2000). Energy usage is dependent on the availability of the conventional resources and the income of the region. Regions with resource availability and high income strive to find a balance between the two, whereas regions with high resources and low income depend on conventional technologies and build an economy that is dependent on fossil fuel technologies (Girod et al., 2009). Regions with low traditional resources and high incomes develop post-fossil technologies (renewable and nuclear). Overall, energy use and demand in the A2 storyline declines at a pace of 0.5 to $0.7 \%$ per year.

The B1 storyline is a theme, based on sustainability, with a high level of emphasis put on environmental and social consciousness (Girod et al., 2009). Increased environmental consciousness might be due to a stronger proof of the negative impacts of past natural resource use practices, such as deforestation, soil depletion, over fishing and pollution (Nakicenovic et al., 2000). Therefore, increased attention towards environmental and social issues by the government, businesses, media and the public is predicted. Technological changes focused on environmental and social development also play a key role in this storyline.

Economic development in the B1 storyline is balanced and efforts to converge per capita income gaps are successful. The B1 storyline has similar results to that of 
the A1 storyline, however, priorities and reasons are different (Nakicenovic et al., 2000). The B1 storyline is driven by environmental and social consciousness, leading to dematerialization and better resource use, whereas the A1 storyline is driven by globalization and economic expansion. The demographic transition of low mortality and fertility in this story line is similar to that of the A1 storyline, although it occurs due to environmental and social concerns and not economic growth (Nakicenovic et al., 2000). Transboundary air pollution is eliminated in the long run regionally, nationally and internationally. Cities are developed in a compact manner to improve and increase public transport. The scenario predicts a major drop in GHG emissions by the year 2100 (Girod et al., 2009).

\subsubsection{Length of Growing Season Modelling}

In the present research project, the aforementioned three climate change scenarios are used. Each of these scenarios covers a wide range of climatic parameters, such as precipitation, temperature, and wind speed. Since the length of the growing season is the single most important factor in determining the growth of trees (Nowak et al., 2004), this factor was selected for use in this project when forecasting tree growth and mortality. The selection process of the scenarios was based on covering the complete spectrum of possible future growing season lengths, and also selecting scenario models with different storylines. Length of growing season is defined as the number of days between the first five consecutive days with mean temperature above $5^{\circ} \mathrm{C}$ (spring) and the last sequence of days (in autumn) with the same mean temperature range (Nakicenovic et al, 2000). The three models selected, project different lengths of growing season based on 
storylines. Growing season lengths are projected using baseline data from 1960 to 2010. While based on models developed by different climate change centers, each is based on previously discussed (A1, A2 and B1) IPCC storylines. The three models can be summarized as follows:

\section{a) NCARPCM Storyline-A2 (Isolation)}

The NCARPCM SR-A2 model was created by the National Centre for Atmospheric Research, USA. This model follows IPCC storyline A2. Until the year 2040, the GHG and aerosol loading predictions show that the length of growing season increases at a medium rate compared to the standardized length being used by i-Tree Eco (153 days for Toronto). Since the storyline showed that technological advances and environmental protection varied with regions, the medium increase in growing season length is reasonable. The average length of growing season projected between the years 2012 and 2040 is 196 days. The largest growing season projected is 209 days in the year 2035. The smallest growing season projected is 179 days in the year 2014. By 2100 the storyline shows a rapid increase in GHG and aerosol loading, resulting in rapid increase in length of growing season. Average precipitation projections over the study period for this model are 2.6 $\mathrm{mm} /$ day.

\section{b) GFDLCM2.1 (Run-1) Storyline-B1 (Sustainability)}


The Geophysics Fluid Dynamics Laboratory, USA, created this model. The model follows the B1 storyline of rapid environmental and social consciousness. The GHG and aerosol loadings for this model show a low increase in length of growing season. In this storyline, dematerialization and an emphasis on clean energy starts making an immediate impact and the model shows the lowest increase in length of growing season. The average length of growing season for this model, between the years 2012 and 2040, is 190 days. This is the smallest increase in growing season length in comparison to standardized length being used by i-Tree Eco in the year 2012 (153 days). The largest growing season length is projected in the year 2032 (233 days). The smallest growing season length is projected in the year 2012 (151 days). Average precipitation projections over the study period for this model are $3.09 \mathrm{~mm} /$ day.

\section{c) MIROC3.2 Storyline-A1B (Globalization)}

This model was created by the National Institute for Environmental Studies, Japan. Although in this storyline there is more emphasis on environmental protection in comparison to the A2 storyline, an increase in length of growing season is higher in this model. The storyline is based on increased emphasis on globalization and technological advances leading to economic growth and trade expansion. Hence, the aerosol and GHG loadings for this model predict the highest average length of growing season between the years 2012 and 2040 (231 days), 
which is the highest increase for all models in comparison to 153 day standardized growth used in i-Tree Eco. The largest growing season in this model is seen in the year 2025 (247 days). The smallest growing season for this model is projected in the year 2012 (211 days). This pattern stays the same throughout the century. The model shows a further increase in length of growing season by 2100 in comparison to baseline data. Average precipitation projections over the study period for this model are $3.44 \mathrm{~mm} /$ day.

\subsection{Tree Growth and Mortality}

Modelling tree growth is the primary route to estimating ecological service provision. Because LA is an instrumental tree characteristic for mitigating the harmful effects of air pollution, elevated summer temperatures and storm water runoff (Akbari et al., 2001; Grapentine, 2009; Nowak, 1994), its accurate estimation is of great importance. Modelling tree growth is challenging due to the longevity of trees, varying dynamics at the growing site of the tree, different management options and the enormous variety of tree species, all having inherently different growth rate potential (McPherson \& Peper, 2012). Peper et al. (2001) and Frelinch (1992) each describes a positive relationship between tree age, DBH and tree height. This allometric relationship was the stepping-stone towards the creation of the US Forest Service's i-Tree tools, which is now used across the globe for estimating ecological services of urban trees (Nowak \& Crane, 2002).

Mortality modelling has been considered a crucial part in the future management of urban trees (Nowak et al., 2004). Similar to growth, mortality is 
dependent on different factors, such as management options, tree site, habitat and species (Lawrence et al., 2012). Pest infestations have always played a major role in urban tree mortality. Other urban factors such as construction, soil compaction and vandalism also impact the mortality rate of urban trees. Nowak et al. (1990) found an average annual tree mortality rate of $19 \%$ for trees along boulevards in Oakland, California; the study reported a mortality of $34 \%$ within 2 years. In another study, Lawrence et al. (2012) found that tree mortality rates varied with a change in land use land cover (LULC) type. Tree mortality rates increased in cases where trees were planted on industrial or commercial areas, and remained the lowest for low to medium populated residential LULC types. When modelling the future energy conservation benefits of trees planted by a non-profit organization in Toronto backyards, Sawka et al. (2013) used the following annual mortality rates: a high annual mortality rate of $1.5 \%$ (high), $0.7 \%$ (low), and $1.1 \%$ (average).

\subsection{Summary}

Forested urban parks provide a variety of ecological benefits, which increase in value with increasing urbanization and changing climate. Ecological services delivered by trees are directly related to their structural growth. The i-Tree suite of tools, especially Eco and Streets, estimate the current ecological services and structure of the urban forest, whereas the new, yet unreleased to the public, iTree Forecast model uses a similar methodology to predict future tree growth and changes in urban forest structural dynamics. A standard length of growing season has been the typical way in which these models have been applied; however, such 
an assumption is unlikely under a future of climate change. Growing seasons for trees are projected to increase across many temperate regions. Therefore, varying the range of growing season length, is proposed in the present project so as to provide plausible scenarios of potential urban tree growth. This approach of manipulating the standard growing season length based on climate change models has not appeared in the literature as it relates to forecasting future urban forest growth. Therefore, this research seeks to document a new methodology by which climate change science can be used to better inform future urban forest management.

\subsection{References}

Akbari, H., Pomerantz, M., \& Taha, H. (2001). Cool surfaces and shade trees to reduce energy use and improve air quality in urban areas. Solar Energy, 70(3), 295-310.

Akbari, H. \& Konopacki, S. (2004). Energy Effects of Heat-Island Reduction Strategies in Toronto, Canada. Energy 29(1):191-210.

Alvey, A. A. (2006). Promoting and preserving biodiversity in the urban forest. Urban Forestry \& Urban Greening, 5(4), 195-201.

Chen, W. Y., \& Jim, C. Y. (2008). Assessment, and valuation of the ecosystem services provided by urban forests. in: Carreiro, M., Y. song and J. wu (eds), Ecology, Planning, and Management of Urban Forests International Perspectives, 53(2).

Dwyer, J.F., Nowak, D.J., Noble, M.H., Sisinni, S.M., (2000). Connecting people with ecosystems in the 21st century, an assessment of our nation's urban forests. General Technical Report, PNW-GTR-490. USDA Forest Service, Pacific Northwest Research Station, Portland OR, p. 483.

Frelich, L. E. (1992). Predicting dimensional relationships for twin cities shade trees. Department of Forest Services, University of Minnesota -Twin Cities

Girod, B., Wiek, A., Mieg, H., \& Hulme, M. (2009). The evolution of the IPCC's emissions scenarios. Environmental Science \& Policy, 12(2), 103-118. 
Grapentine, L., Rochfort, Q., \& Marsalek, J. (2008). Assessing urban stormwater toxicity: Methodology evolution from point observations to longitudinal profiling. Water Science and Technology, 57(3), 1375.

Groombridge, B., \& Jenkins, M. (2002). World atlas of biodiversity earth's living resources in the 21st century. Berkley, CA: University of California Press.

Jansson, M., \& Lindgren, T. (2012). A review of the concept 'management' in relation to urban landscapes and green spaces: Toward a holistic understanding. Urban Forestry \& Urban Greening, 11(2), 139-145.

Jim, C. Y., \& Liu, H. T. (2001). Species diversity of three major urban forest types in guangzhou city, china. Forest Ecology and Management, 146(133), 99.

Kenney, A., van Waessenaer, P., \& Satel, A. (2010). Sustainable urban forest management planning using criteria \& indicators. Cities and the Environment, 3(1), August 13, 2010-Poster 16.

Lawrence, A. B., Escobedo, F. J., Staudhammer, C. L., \& Zipperer, W. (2012). Analyzing growth and mortality in a subtropical urban forest ecosystem. Landscape and Urban Planning, 104(1), 85-94.

McKinney, M.L., (2006). Urbanization as a major cause of biotic homogenization. Biological Conservation 127, 247-260.

McLean, D., Ryan, J., \& Hurd, A. (2007). Seeing the urban forest through the trees: Building depth through qualitative research. Arboriculture and Urban Forestry, 33(1), 308.

McPherson, E. G., Simpson, J. R., Peper, P. J., Gardner, S. L., Vargas, K. E., Maco, S. E., \& Xiao, Q. (2006). Piedmont community tree guide: Benefits, costs, and strategic planting. (No. PSW-GTR-200). USDA Forest Service General Technical Report.

McPherson, G., \& Peper, P. (2012). Urban tree growth modeling. Arboriculture and Urban Forestry, 38(5), 172-180.

McPherson, G., Simpson, J. R., Peper, P. J., Maco, S., \& Xiao, Q. (2005). Municipal forest benefits and costs in five US cities Journal of Forestry, 103(8), 411-416.

Millward, A. A., \& Sabir, S. (2010). Structure of a forested urban park: Implications for strategic management. Journal of Environmental Management, 91(11), 2215-2224. 
Millward, A. A., \& Sabir, S. (2011). Benefits of a forested urban park: What is the value of allan gardens to the city of toronto, canada? Landscape and Urban Planning, 100(3), 177-188.

Morgan, G., 1991. A Strategic Approach to the Planning and Management of Parks and Open Spaces. The Institute of Leisure \& Amenity Management, Berkshire.

Nakicenovic, N., Alcamo, J., Davis, G., de Vries, B., Fenhann, J., Gaffin, S., Dadi, Z. (2000). Special report on emission scenerios . (Special Report No. 1). Cambridge, United Kingdom: Intergovernmental Panel on Climate Change. . (IPCC Special Report)

Nikoofard, S., Ugursal., V. I., \& Beausoleil-Morrison, I. (2011). Effect of external shading on household energy requirement for heating and cooling in canada. Energy \& Buildings, 43(7), 1627-1635.

Nowak, D., McBride, J., Beatty, R. (1990). Newly planted street tree growth and mortality. Journal of Arboriculture, 16(5).124-128.

Nowak, D. J. (1994). Atmospheric carbon dioxide reduction by Chicago's urban forest. In E. G. McPherson, D. J. Nowak, R. A. Rowntree (Eds.), Chicago's Urban Forest Ecosystem: Results of the Chicago Urban Forest Climate Project (USDA Forest Service General Technical Report NE-186, pp. 83-94), Radnor, PA.

Nowak, D. J., Kuroda, M., \& Crane, D. E. (2004). Tree mortality rates and tree population projections in baltimore, maryland, USA. Urban Forestry \& Urban Greening, 2(3), 139-147.

Nowak, D. J., \& Walton, J. (2006). Projected urban growth (2000-2050) and its estimated impact on the US forest resource Journal of Forestry, 103(8), 383.

Nowak, D. J., \& Crane, D. E. (2002). Carbon storage and sequestration by urban trees in the USA. Environmental Pollution, 116(3), 381-389.

Pachauri, R., \& Reisinger, A. (2007). Climate change 2007: Synthesis report. contribution of working groups I, II and III to the fourth assessment report of the intergovernmental panel on climate change. (No. 4). Geneva, Switzerland: Intergovernmental Panel of Climate Change. Retrieved from http://www.ipcc.ch/pdf/assessment-report/ar4/syr/ar4_syr.pdf

Peper, P., McPherson, G., \& Mori, S. (2001). Predictive equations for dimensions and leaf area of coastal southern california street trees. Journal of Arboriculture 27(4): July 2001, 27(4), 169. 
Peper, P., McPherson, G., \& Mori, S. (2001b). Equations for predicting diameter, height, crown width and leaf area of san joaquin valley street trees. Journal of Arboriculture 27(4): July 2001, 27(4), 169.

Peper, P. J., \& McPherson, E. G. (2003). Evaluation of four methods for estimating leaf area of isolated trees. Urban Forestry \& Urban Greening, 2(1), 19-29.

Randrup, T. B., \& Persson, B. (2009). Public green spaces in the nordic countries: Development of a new strategic management regime. Urban Forestry \& Urban Greening, 8(1), 31-40.

Roloff, A., Korn, S., \& Gillner, S. (2009). The climate-species-matrix to select tree species for urban habitats considering climate change. Urban Forestry \& Urban Greening, 8(4), 295-308.

Sawka, M., Millward, A. A., Mckay, J., \& Sarkovich, M. (2013). Growing summer energy conservation through residential tree planting. Landscape and Urban Planning, 113(1), 1-9. 


\section{Chapter 3}

\subsection{Abstract}

Climate change is expected to lengthen the growing season for plants in many temperate regions, while at the same time it is anticipated that it will cause changes in precipitation patterns, severe storm events and pests, all of which may stress existing urban forests and could increase tree mortality. The purpose of this study was to develop future growth estimates for trees in Earlscourt Park, Toronto. The i-Tree Forecast model, in combination with various climate change scenarios provided by the Canadian Climate Change Scenario Network, were used to build trajectories of tree growth and mortality. From these scenarios, Toronto-specific growing season lengths were determined annually from 2011 to 2040 . Two rates of annual tree mortality ( 0.7 and $1.3 \%)$, as well as a future replanting plan were also used in the forecast models. Model tree growth forecasts, measured in terms of diameter at breast height (DBH) and leaf biomass were greatest for the climate change scenario with the longest growing season length. Results also highlight future vulnerability in two common tree species, honey locust and Norway maple. Forecasting of tree growth and mortality for urban parks provides important details around which management planning can occur to maximize the flow of future ecological benefits received by proximate urban neighbourhoods.

Keywords: tree growth, tree mortality, i-Tree Eco, i-Tree Forecast, growing season length, urban park sustainability, management plan 


\subsection{Introduction}

Urban populations are increasing globally, which is leading to significant alterations to land cover and land use (LULC), increases in pollution, and also may be an important driver of climate change (McPherson et al., 2005). The pace of urbanization in recent decades has enhanced the urban heat island phenomenon, which is characterized by urban centres having higher temperatures than surrounding rural areas (Seto et al., 2010). Urban park trees play a major role in delivering ecological services to communities to mitigate these negative effects of urbanization. In addition to ecological benefits, trees also provide other social benefits (e.g., improved property value, increased residential privacy, improved aesthetic value) (Millward \& Sabir, 2011, Martin et al., 2011; Alvey, 2006). Studies in the past have shown that urban parks can deliver a benefit-to-cost ratio of 3.4:1 (Millward \& Sabir, 2011). The importance of these benefits will rise in the future, as more people migrate from rural to urban areas. It is important to understand the ecological value provided by each tree species present within urban parks, as different species are better at delivering specific benefits (e.g., storm water runoff management, mitigation of air pollution).

Plants are well known for their ability to capture carbon dioxide $\left(\mathrm{CO}_{2}\right)$ and sequester it in the form of woody biomass (Nowak \& Crane, 2002). Urban trees have been shown to have the capacity to sequester large amounts of $\mathrm{CO}_{2}$ and act as carbon sinks (Nowak \& Crane, 2002). An evaluation of data from 10 cities in the Unites States showed that urban trees have the capacity to sequester 658 million tonnes of carbon annually (Nowak et al., 2012). A study of Allan Gardens, an urban park in Toronto, showed that the park reduced annual atmospheric $\mathrm{CO}_{2}$ by 51,895 
$\mathrm{kg}$, valued at $\$ 858 /$ year (Millward \& Sabir, 2011). Urban trees can also impact release of carbon dioxide through their energy shading and evapotranspirative cooling benefits. Less demand for electricity translates into less release of $\mathrm{CO}_{2}$ (Nowak et al., 2012). Understanding this benefit of urban trees can assist in preparing more detailed GHG (greenhouse gas) inventories (Nowak \& Walton, 2006).

Air pollution can impose serious risks to human health, as observed around the world in regions with poor air quality (Pachauri \& Reisinger, 2007). Trees ameliorate air pollution by absorbing pollutants such as nitrogen dioxide $\left(\mathrm{NO}_{2}\right)$, carbon monoxide $(\mathrm{CO})$ and ozone $\left(\mathrm{O}_{3}\right)$. Trees also serve to reduce particulate matter (PM2.5) in the air by intercepting particulates via their broad leaves (Chen \& Jim, 2008). Trees also release oxygen into the atmosphere through the process of photosynthesis, which can further improve the quality of the urban atmosphere. Some pollutants, like sulpher dioxide $\left(\mathrm{SO}_{2}\right)$ and nitrogen dioxide $\left(\mathrm{NO}_{2}\right)$, can react with water found in the inner leaf cells to form sulphuric, sulphurous, nitric and nitrous acids (Chen \& Jim 2008). These acids are transferred into other plant cells and are eventually assimilated and fixed within the plant tissue.

Tree canopies play a critical role in preventing buildings from warming by shading them. In the absence of shade, buildings heat up rather quickly, leading to an increase in energy consumption (Jensen et al., 2003). Studies have shown this increase to be $4 \%$ for every $1^{\circ} \mathrm{C}$ increase in temperature (Jensen et al., 2003; McPherson et al., 1997). Trees also cool buildings and paved areas through evapotranspiration. These cooling benefits help reduce the occurrence of the urban 
heat island effect (Akbari, et al., 2001). In the winter, trees act as wind barriers that decrease the amount of wind penetrating buildings, thus shielding buildings from cold winter winds that promote indoor heating (McPherson et al., 1997).

It is critical to evaluate urban forests not only for the benefits they provide to the community in the present day, but also for future benefits. The ecological benefits of trees are heavily dependent on the size of the tree, especially concerning leaf area (LA) (Peper et al., 2001a). Studies have shown a strong correlation between tree age and growth. Not only is the diameter at breast height $(\mathrm{DBH})$ positively correlated to the age of the tree, but there is also a correlation between the $\mathrm{DBH}$ growth rate and age in terms of rate of increase in size (Frelich, 1992). General knowledge of tree growth and mortality rates coupled with age and species-specific growth correlations can assist with estimation of the future benefits flowing from urban forests (Lawrence, 2010). It is well known that trees are more beneficial when leaf area and canopy size are larger, which is generally the case in older trees with high DBH measurements (Peper, 2001a). However, as growth and ageing occur, there will be a point in the future when large trees will die and the benefits they provide to the community will cease. Hence, future management strategies need to be in place for the replacement of these trees, where these strategies should be based on more than replanting for numbers. Instead, knowledge of ecological benefits provided by particular species should be critical in future management strategies. By forecasting the ecological benefits that current trees deliver in the future, and by modelling with replanting scenarios, urban forest management planning can be improve dramatically. 
As the health of urban forests is based primarily on environmental conditions, modeling the impact on city trees of future climate change is essential to understanding the fate of this resource. Expanding growing season durations in the future are likely to have the greatest overall influence on the growth rates of city trees. Knowing how the benefits delivered by trees in the future may change is likely to influence the decisions of policy makers concerning new approaches to the current management of city trees.

The purpose of this study is to forecast changes in urban forest structure and provision of ecological benefits for a treed urban park in Toronto, Canada. By integrating growth and mortality rates with several climate change scenarios, the future importance value of three dominant park tree species is investigated. An assessment of tree population change in terms of size distribution and the growth of individual trees, as reflected in $\mathrm{DBH}$, is followed from the present until the year 2040

The study uses two i-Tree models, Eco and Forecast. Eco is used to benchmark the present structure and associated ecological services delivered by park trees, while Forecast takes these current conditions and 'grows' the future urban park forest based on specific details pertaining to length of growing season, mortality rate and future tree replanting inputs. By using three unique climate change models, growing season length is varied and several realistic trajectories of future tree growth are generated. The research has been designed in such a way that the methodology can be applied to any forested urban park, provided that geographic location is identified in the context of selecting appropriate climate change scenarios and varying growing season length accordingly. 


\subsection{Methods}

\subsubsection{Study Site}

Earlscourt Park is located in the Davenport riding in the western end of the City of Toronto. It is located in an area that encompasses a mix of industrial, residential and commercial land use (GreenHere, 2009). The park itself is located in a low-income neighborhood and contains 601 trees with DBH greater than 5.9 $\mathrm{cm}$. The eastern and southern boundary of the park borders with residential properties while the western and northern boundaries are bordered by commercial properties. A community recreation centre with an outdoor swimming pool is situated on the northeastern edge of the park. It is an ideal study site due to its high species biodiversity (35) and large variation in tree size. The overall size and design of the park (Figure 3.1) has resulted in different amounts of crown light exposure (CLE), which is a key component of tree growth. Ecological services provided by the trees, such as pollution avoidance, carbon storage and rainfall water interception, are even more important in this region due to the mix industrial and residential LULC nature of the community. With several industries and rail tracks intertwined with residential areas, the community benefits from pollution removed by forested urban parks like Earlscourt. 


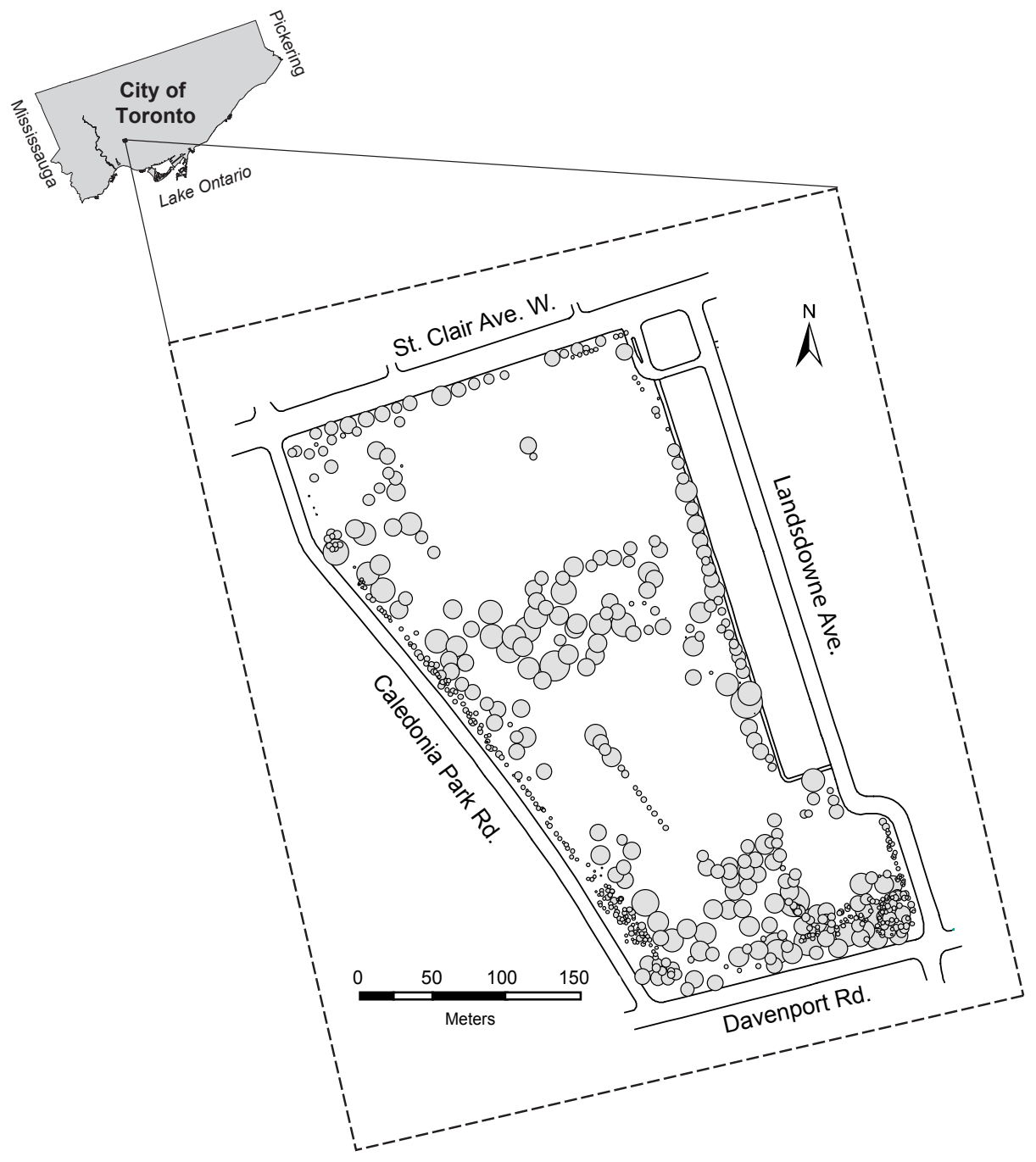

Figure 3.1: Location of Earlscourt Park in Toronto, Canada. Shaded circles are park trees inventoried in 2012 and have been scaled to reflect actual canopy width. 


\subsubsection{Data Collection}

A complete tree inventory was conducted for Earlscourt Park between May 10, 2012, and August 05, 2012 following the i-Tree data collection protocol. Tree species, DBH, height, canopy width, CLE, dieback and missing canopy were recorded for each tree in the park. Although a similar inventory was completed for the park in the year 2008 by a local NGO, a more recent inventory was necessary due to new plantings and the removal of some trees.

Tree species, growing location and other measurements were mapped with the use of two spatial data layers. An orthorectified aerial leaf-off coloured image and geo-referenced boundary layers containing building, sidewalk and road locations were used. Using Arc GIS, the boundary layer was overlaid on the aerial image to assist with field navigation. Actual tree locations were plotted into a separate vector layer based on distance of location from boundaries, measured using a survey-grade measuring wheel.

DBH was measured using a forestry tape at a trunk height of 1.37 meters. In cases where trees had more than 1 trunk, all trunks were measured separately. Height was measured using a standard clinometer. Canopy width was measured in two perpendicular directions using a measuring tape. Missing canopy and crown dieback was assessed using photographic images taken from 2 to 4 different angles during tree measurement. Grid calculations were conducted for a sample of the dieback and missing canopy estimates; these computer-aided calculations served to verify that field-calculations were accurate. CLE was calculated using a mix of on-site assessment, processing of photographs taken during data collection and aerial imagery. 
Data were organized into MS Access file format, which is used to upload data to the i-Tree Eco servers. Following processing, results are returned in the form of ecological services provided by the tree population to the community. iTree Eco requires the designation of a weather station for meteorological data. For this site, Pearson International Airport's weather station was selected due to its proximity to the park.

\subsection{3 i-Tree Eco}

i-Tree is a peer reviewed suite of urban forestry tools developed by the US Forest Service (Nowak et al., 2008; i-Tree 2012). i-Tree has two core modules for estimating tree benefits, Eco and Streets. Each model estimates the benefits provided by urban trees based on an inventory of tree characteristics (Nowak et al., 2008). Many studies have used Streets to investigate the benefits delivered by urban street trees (Millward \& Sabir, 2010); Eco is a fairly new addition of conducting complete tree inventories (i.e., first available for this purpose in 2009; iTree ver. 3). Eco uses a much more detailed range of tree inventory data in comparison to Streets. For this reason, it is considered to be the more effective method for assessing the benefits provided by urban trees due to its highly detailed inventory requirements. In our study, we used i-Tree Eco ver. 5, which allows for direct calculations of tree benefits for Canadian cities. Previous versions of Eco were not capable of doing this and Canadian data had to be submitted manually to i-Tree staff in Syracuse, NY for processing.

The Eco model uses tree-specific characteristics in allometric equations to calculate LA and growth curves specific to urban trees (i-Tree, 2012). Where trees 
are larger than the parameters specified for species-specific allometric equations, LA was calculated using extrapolation techniques (Nowak et al., 2008). Carbon storage and sequestration are measured using tree biomass data in conjunction with growth estimates. Standardized growth rates were then adjusted in Eco based on CLE, missing canopy and crown dieback (Nowak \& Crane, 2002). Among other benefits, this process yielded tree-specific estimates of carbon storage and carbon sequestration.

Eco uses a hybrid approach to calculate air pollution abatement, combining multi-layer modelling with big leaf modelling (Baldochhi et al., 1987; Baldochhi et al., 1988). Tree specific LA calculations are combined with local hourly air pollution data and local weather data (Nowak \& Crane, 2000; Nowak et al., 2008). For the present project, Eco was used to calculate the removal of $\mathrm{CO}, \mathrm{NO}_{2}, \mathrm{SO}_{2}, \mathrm{O}_{3}$ and PM2.5.

Rainfall interception was introduced to Eco after the development of a new program called i-Tree Hydro. The module is based on a scenario-based approach (Hirabayashi, 2013). It takes into account two scenarios. In the first scenario, the rainfall is partially intercepted by the canopy and upon reaching the ground it either percolates into the soil (in the case of a pervious surface) or runs over impervious surface as surface runoff (Hirabayashi, 2013). The second scenario uses the same approach; however, in this scenario no vegetation cover is assumed and the rain falls directly onto the ground (Hirabayashi, 2013). Avoided runoff due to canopy interception is calculated by taking into account the difference in surface runoff resulting from each of these scenarios (Hirabayashi, 2013). 


\subsection{4 i-Tree Forecast}

i-Tree has developed a new tool called Forecast, which has not been released publically yet. The purpose of Forecast is to estimate the future structure and function of an urban tree population. The Forecast model is based on i-Tree Eco and a Kansas City forest report produced by Nowak et al. (2012). This report details a study in Kansas City regional forest that was conducted to assess the future value of services delivered by the forest. The study developed a tree growth projection model to estimate the canopy change. Tree growth in the model was based on species growth rate, length of growing season, maturation height, crown competition, and canopy condition. For every tree in the data set, an assumption of 100 trees is made and based on the annual maximum and minimum mortality rate, the number of assumed trees is reduced to show the chance of survivorship for each real tree.

Tree mortality rates are also adjusted based on the species, size class, DBH class and crown dieback. Trees with a crown dieback of 50 to $75 \%$ have a mortality rate of $13.1 \%$ and trees with a crown dieback of 75 to $100 \%$ have a mortality rate of $50 \%$. Trees are assigned to size classes (i.e., small, medium and large) and each size class has a set of diameter ranges to which base mortality rates were applied (Nowak et al., 2012). These descriptions of tree canopy and DBH condition are collected during the inventory assembly process of i-Tree Eco project preparation. While the Forecast model is yet unreleased, the i-Tree team processed Earlscourt Park data collected as part of the present project. However, iTree forecast does not use precipitation patterns in its modelling technique, which is a current limitation. 


\subsubsection{Growing Season}

Length of growing season is a key component in growth estimates of urban trees (Nowak et al., 2008). In i-Tree Eco, growth estimates are completed based on standardized lengths of growing season influenced by different climate regions (Nowak et al., 2008). In its current form, the i-Tree Forecast model projects future tree growth and future carbon storage based on standardized lengths of growing season. To generate plausible future scenarios concerning changing length of growing season, three different lengths of growing season were determined from three independent climate change scenario models.

Specifically, selection of models was based on a decision to include a broad range of climate change storylines. The models selected for this study were GFDLCM (Sustainability), NCARPCM (Isolation) and MIROC (Globalization). Each model was developed based on different storylines generated in the Intergovernmental Panel for Climate Change (IPCC) 2007 Report. The storylines hypothesized different political, cultural and technological positions emerging over the $21^{\text {st }}$ Century (IPCC, 2007). The GFDLCM model shows minimum increase in length of growing season. NCARPCM depicted a slightly higher change in length of growing season. MIROC showed the highest increase in future length of growing season (Table 3.1).

The standardized growing season lengths used in Forecast (153 days) were then substituted with annual growing season lengths obtained from the climate change models. Varying growing season length is one approach to establishing what Earlscourt Park may look like under different climate futures. 
Table 3.1 Annual length of Growing Season model predictions for GFDLCM, NCARPCM, MIROC

\begin{tabular}{|c|c|c|c|}
\hline Year & GFDLCM & NCARPCM & MIROC \\
\hline 2012 & 151 & 188 & 211 \\
\hline 2013 & 206 & 206 & 233 \\
\hline 2014 & 190 & 179 & 232 \\
\hline 2015 & 198 & 200 & 226 \\
\hline 2016 & 206 & 204 & 224 \\
\hline 2017 & 178 & 191 & 227 \\
\hline 2018 & 173 & 199 & 220 \\
\hline 2019 & 200 & 201 & 219 \\
\hline 2020 & 164 & 196 & 230 \\
\hline 2021 & 173 & 199 & 217 \\
\hline 2022 & 174 & 194 & 240 \\
\hline 2023 & 218 & 201 & 228 \\
\hline 2024 & 209 & 186 & 237 \\
\hline 2025 & 198 & 192 & 246 \\
\hline 2026 & 186 & 185 & 233 \\
\hline 2027 & 164 & 190 & 237 \\
\hline 2028 & 197 & 203 & 229 \\
\hline 2029 & 166 & 193 & 239 \\
\hline 2030 & 192 & 181 & 226 \\
\hline 2031 & 191 & 198 & 239 \\
\hline 2032 & 233 & 209 & 229 \\
\hline 2033 & 189 & 195 & 232 \\
\hline 2034 & 212 & 198 & 218 \\
\hline 2035 & 173 & 209 & 239 \\
\hline 2036 & 196 & 198 & 234 \\
\hline 2037 & 189 & 194 & 236 \\
\hline 2038 & 193 & 199 & 226 \\
\hline 2039 & 194 & 202 & 231 \\
\hline 2040 & 211 & 208 & 240 \\
\hline
\end{tabular}




\subsubsection{Planting and Mortality}

In order to forecast the future structure of an urban park, it is necessary to consider new plantings that might occur at some future date. One of the biggest threats to urban forest communities is pest infestation (City of Toronto, 2013). Trees in North America have already suffered from the Dutch elm disease (DED) and are now in the midst of another similar crisis as a result of emerald ash borer (EAB) infestation (City of Toronto, 2013). At present, $E A B$ is the largest threat to urban trees in Toronto. The City of Toronto has projected that by the year 2017 all ash trees in the city will have died (City of Toronto, 2013). Earlscourt Park has an ash population of $14.7 \%$ ( 88 trees). In addition to the immediate threat to the ash population, mature trees in the park will also reach the end of their natural life cycle in the coming decades. Therefore, replacement planning for both the loss in ash trees and the loss of other mature trees that are likely to die relatively soon, is crucial so as to sustain the park's ecological services at par with present levels. In order to evaluate the effects of future plantings, the present study used control projections for each of the growth models excluding future planting of new trees. This modeling exercise permitted comparison of models with and without new plantings.

A tree planting matrix for Earlscourt Park was created that details a future planting schedule that includes year of planting, tree species, and size of tree at planting (Table 3.2). The planting matrix was developed based upon fundamentals of biodiversity, age composition, longevity and ecological services delivered by Earlscourt Park trees. Species selection was based on planting recommendations currently made by the City of Toronto and by Local Enhancement and Appreciation 
of Forests (LEAF), a Toronto-based non-profit specializing in urban afforestation. The future planting schedule includes 11 species, which were overlapping in the recommendations made by the two aforementioned agencies. From 2013 through 2017, 18 new trees are planted each year (2 species per year) to replace the dying ash population. After the initial ash tree replacement, three plantings of 12 trees per year at 5-year intervals were done to cover general mortality. In order to maintain species diversity, no more than 2 trees of the same genus were planted in the same year. Furthermore, to spread out the age composition, trees of the same genus were planted with a minimum gap of 2 years between them. Planting of fast growing tree species were balanced with more hardy trees (i.e., tolerant of urban conditions). All new plantings were conducted with trees that had a $\mathrm{DBH}$ of $10 \mathrm{~cm}$, where this tree size is the average planted by the City of Toronto and other agencies.

Tree mortality plays a major role in this study. Two different mortality approaches were used in the Forecast model for Earlscourt Park. As mentioned earlier, the ash trees threatened by the EAB have a very high mortality rate and are predicted to die between the years 2016-2017. However, the rest of the park's trees are in good overall condition. Therefore, a separate mortality model was developed for ash trees that removed all of them from the park by 2017. General mortality rates have not been studied systematically for urban trees, and varied rates have been used in previous studies. After interviewing tree maintenance contractors, McPherson (1993) indicates that 15 to $30 \%$ of trees may die within the first 5 years following planting. Thereafter, 0.2 to $2 \%$ may die each year. In a 
Table 3.2: Planting matrix used in the model where new trees have a $10 \mathrm{~cm} \mathrm{DBH}$

\begin{tabular}{lrrrrrrrrr}
\hline Values & 2013 & 2014 & 2015 & 2016 & 2017 & 2020 & 2025 & 2030 & Total \\
\hline Basswood & 0 & 0 & 0 & 0 & 9 & 0 & 0 & 3 & 12 \\
Silver maple & 0 & 0 & 9 & 0 & 0 & 0 & 3 & 0 & 12 \\
Ironwood & 0 & 0 & 9 & 0 & 0 & 0 & 0 & 3 & 12 \\
Hackberry & 0 & 0 & 0 & 0 & 9 & 0 & 0 & 3 & 12 \\
Red maple & 0 & 0 & 0 & 0 & 0 & 3 & 0 & 3 & 6 \\
Freeman maple & 0 & 0 & 0 & 9 & 0 & 0 & 3 & 0 & 12 \\
Bur oak & 0 & 0 & 0 & 9 & 0 & 0 & 3 & 0 & 12 \\
Red oak & 9 & 0 & 0 & 0 & 0 & 3 & 0 & 0 & 12 \\
Sugar ma & 9 & 0 & 0 & 0 & 0 & 3 & 0 & 0 & 12 \\
Kentucky coffeetree & 0 & 9 & 0 & 0 & 0 & 3 & 0 & 0 & 12 \\
Honey locust & 0 & 9 & 0 & 0 & 0 & 0 & 3 & 0 & 12
\end{tabular}


different study, McPherson and Simpson (1999) use a mortality rate of $1.4 \%$. Sawka et al. (2013) used a high mortality rate of $1.5 \%$ per year and a low rate of $0.7 \%$ when studying trees planted in Toronto backyards.

The mortality rates used by Sawka et al. (2013) are likely somewhat low (conservative) for a park setting, where urban park trees typically receive less attention than privately owned backyard trees. Because there are no specific mortality rates reported for trees growing in urban parks, we used the same maximum and minimum mortality rates as Sawka et al. (2013), as both studies were conducted in the same geographic region and contained similar tree species. These mortality scenarios were subsequently integrated into the i-Tree Forecast model for Earlscourt Park. By combining three different projections of growing season length through 2040 , and by introducing several tree mortality scenarios along with a comprehensive replanting schedule, this project has created a hybrid growth forecast model for the future of trees in Earlscourt Park.

\subsection{Results}

In this section, the present ecological services and structure of Earlscourt Park trees are presented. This is followed by results of the tree growth Forecast model for abundant tree species within the park under different climate models (reflected in growing season length) and mortality rates.

\subsubsection{Current Urban Forest Structure and Ecological Services}

\subsubsection{Park Structure}


The park is comprised 35 unique tree species constituting a population of 601 trees. The species with the greatest number of trees in the park is Norway maple (Acer platanoides, 128 trees), which account for $21.3 \%$ of the park tree population (Table 3.3). Little-leaf linden (Tilia cordata); green ash (Fraxinus pennsylvanica) and honey locust (Gleditsia triacanthos) have 41 trees each. These four species account for $40.8 \%$ of the total tree population in the park. Total LA for the park canopy is $187,183 \mathrm{~m}^{2}$. The top three species growing in the park in terms of LA are Norway maple (37.2\%), little-leaf linden (11.8\%) and silver maple (Acer saccharinum). Silver maple accounts for $6.1 \%$ of the LA, even though it is only $3.9 \%$ of the total population. London plane (Platanus $\times$ acerifolia) accounts for $6.7 \%$ of the total LA and there are only 6 London planes in the park, encompassing merely $1 \%$ of the total population. Norway maple and Little-leaf linden are the two largest park tree species in terms of leaf biomass; Red pine (Pinus resinosa) contains $6.1 \%$ of the total biomass with a tree count of 26 , which is $4.3 \%$ of the park population.

\subsubsection{Carbon Storage and Sequestration}

Earlscourt Park trees were estimated to have sequestered $4,249 \mathrm{~kg}$ of carbon in the year 2012. Within the park, Norway maples sequester the most carbon (1,469 kg/year, 34.6\%) followed by Little-leaf linden (392.5 kg/year, 9.3\%) and Honey locust (385.1 kg/year, 9.1\%). Although these three species provide the greatest species-specific carbon sequestration, this was in part due to the fact that

they are the most abundant species in the park. On an individual tree basis, London plane and sugar maple (Acer saccharum) sequestered on average 17.1 
Table 3.3: Tree species characteristics estimated using i-Tree Eco with a standardized length of growing season (153 days for Toronto)

\begin{tabular}{|c|c|c|c|c|c|c|c|c|c|c|c|}
\hline Species Name & Count & $\begin{array}{l}\text { Canopy } \\
\text { Cover } \\
(\mathrm{m} 2)\end{array}$ & $\%$ & $\begin{array}{l}\text { Leaf Area } \\
(\mathrm{m} 2)\end{array}$ & $\%$ & $\begin{array}{l}\text { Leaf } \\
\text { Biomass } \\
(\mathrm{kg})\end{array}$ & $\%$ & $\begin{array}{l}\text { Carbon } \\
\text { Storage } \\
(\mathrm{kg})\end{array}$ & $\%$ & $\begin{array}{l}\text { Carbon } \\
\text { Seq (kg/yr) }\end{array}$ & $\%$ \\
\hline Norway maple & 128 & 13279.3 & 31.69 & 69689.5 & 37.23 & 3761.4 & 29.88 & 62928.4 & 34.98 & 1469.9 & 34.59 \\
\hline Littleleaf linden & 41 & 3760.6 & 8.97 & 22143.5 & 11.83 & 1658.7 & 13.18 & 17761.1 & 9.87 & 392.5 & 9.24 \\
\hline Silver maple & 21 & 2743.6 & 6.55 & 11434.7 & 6.11 & 601.8 & 4.78 & 11784.2 & 6.55 & 197.9 & 4.66 \\
\hline Black walnut & 27 & 1026 & 2.45 & 8492.9 & 4.54 & 680.7 & 5.41 & 3068.9 & 1.71 & 101.5 & 2.39 \\
\hline Green ash & 41 & 2402.1 & 5.73 & 8325.3 & 4.45 & 543 & 4.31 & 4307.4 & 2.39 & 111.4 & 2.62 \\
\hline Honeylocust & 41 & 4581.3 & 10.93 & 6865.2 & 3.67 & 718.9 & 5.71 & 13403.7 & 7.45 & 385.1 & 9.06 \\
\hline London plane & 6 & 1054.4 & 2.52 & 6858.2 & 3.66 & 315 & 2.5 & 4584.5 & 2.55 & 102.5 & 2.41 \\
\hline Bur oak & 18 & 1646.1 & 3.93 & 5611.6 & 3 & 553.8 & 4.4 & 9058.3 & 5.04 & 188.6 & 4.44 \\
\hline Red pine & 26 & 1346.8 & 3.21 & 5483 & 2.93 & 806.3 & 6.41 & 5534.4 & 3.08 & 136.7 & 3.22 \\
\hline Sugar maple & 13 & 1361.3 & 3.25 & 5357.4 & 2.86 & 322.7 & 2.56 & 6485.2 & 3.6 & 158.8 & 3.74 \\
\hline White oak & 4 & 1310.8 & 3.13 & 3430.6 & 1.83 & 249.6 & 1.98 & 9565.5 & 5.32 & 158.3 & 3.73 \\
\hline Northern red oak & 27 & 814.3 & 1.94 & 3333.7 & 1.78 & 265.6 & 2.11 & 3411.8 & 1.9 & 106.9 & 2.52 \\
\hline Swamp white oak & 4 & 1044.3 & 2.49 & 3271.4 & 1.75 & 322.9 & 2.56 & 9436.7 & 5.25 & 102.8 & 2.42 \\
\hline $\begin{array}{l}\text { Eastern white } \\
\text { pine }\end{array}$ & 38 & 559.3 & 1.33 & 2847.3 & 1.52 & 183.1 & 1.45 & 1624.9 & 0.9 & 75.6 & 1.78 \\
\hline $\begin{array}{l}\text { American } \\
\text { basswood }\end{array}$ & 7 & 397.7 & 0.95 & 2619.3 & 1.4 & 76.5 & 0.61 & 1977.6 & 1.1 & 52.4 & 1.23 \\
\hline Freeman maple & 23 & 349.7 & 0.83 & 2564.4 & 1.37 & 144.3 & 1.15 & 706 & 0.39 & 59.8 & 1.41 \\
\hline Red Ash & 37 & 619.9 & 1.48 & 2536.3 & 1.35 & 189.9 & 1.51 & 1093.2 & 0.61 & 65.7 & 1.55 \\
\hline Black ash & 11 & 589.2 & 1.41 & 2444.7 & 1.31 & 145.5 & 1.16 & 2128.8 & 1.18 & 54 & 1.27 \\
\hline $\begin{array}{l}\text { Kentucky } \\
\text { coffeetree }\end{array}$ & 7 & 466 & 1.11 & 2005.6 & 1.07 & 150.2 & 1.19 & 1661.4 & 0.92 & 38.1 & 0.9 \\
\hline Boxelder & 21 & 509.3 & 1.22 & 1919.9 & 1.03 & 175.6 & 1.4 & 772.9 & 0.43 & 50.8 & 1.19 \\
\hline Others & 60 & 2039.8 & 4.86 & 9948.7 & 5.32 & 722.1 & 5.73 & 8607.4 & 4.78 & 240.2 & 5.66 \\
\hline TOTAL & 601 & 41902 & 100 & 187183 & 100 & 12587 & 100 & 179902 & 100 & 4249 & 100 \\
\hline
\end{tabular}


$\mathrm{kg} /$ year and $12.2 \mathrm{~kg} / \mathrm{year}$ of carbon, respectively. This was followed by honey locust and little-leaf linden at $9.6 \mathrm{~kg} / \mathrm{year}$ and $9.4 \mathrm{~kg} / \mathrm{year}$, respectively. The most abundant tree species, Norway maple, performed better at sequestering carbon than the honey locust and little-leaf linden at $11.5 \mathrm{~kg} / \mathrm{year}$, but not as well as the London plane or sugar maple. The annual average for a park tree is $7.1 \mathrm{~kg}$.

Stored carbon refers to the amount of carbon in a tree's above and belowground biomass. Earlscourt Park stored a total of $179,902 \mathrm{~kg}$ of carbon in 2012. Of this total, $35 \%$ was stored in Norway maple, followed again by little-leaf linden and honey locust with $9.9 \%$ and $7.5 \%$, respectively. Reviewing the average carbon storage values on a per tree basis, London plane $(764 \mathrm{~kg} / \mathrm{tree})$, silver maple (561 kg/tree) and bur oak (Quercus macrocarpa) (503 kg/tree) store more carbon than Norway maple (491 kg/tree), little-leaf linden $(433 \mathrm{~kg} / \mathrm{tree})$ and honey locust (326 kg/tree). All six of these species perform better than the park average per tree, which is $299 \mathrm{~kg} / \mathrm{tree}$.

\subsubsection{Air Pollution Abatement}

i-Tree Eco estimated that in 2012 trees in Earlscourt Park contributed to an annual reduction of $173.9 \mathrm{~kg}$ in air pollution; this included $\mathrm{CO}, \mathrm{O}_{3}, \mathrm{NO}_{2}, \mathrm{SO}_{2}$ and PM2.5. Of the park tree species, Norway maple trees performed the best in terms of mitigating air pollution $(42.7 \mathrm{~kg} / \mathrm{yr})$. It was followed by little-leaf linden trees (19.3 $\mathrm{kg} / \mathrm{yr})$ and honey locust $(8.3 \mathrm{~kg} / \mathrm{yr})$. However, on a species-specific average per tree basis, London plane performed the best $(0.66 \mathrm{~kg} / \mathrm{yr}$ per tree $)$ of air pollution removal compared with $0.33 \mathrm{~kg} / \mathrm{yr}$ per tree by Norway maple. 
On a pollutant-by-pollutant basis, $130.5 \mathrm{~kg}$ of $\mathrm{O}_{3}$ was estimated to have been removed by Earlscourt Park trees in 2012; this was followed by $33.4 \mathrm{~kg}$ of $\mathrm{NO}_{2}$ and $5.4 \mathrm{~kg}$ of $\mathrm{SO}_{2}$. The five most abundant tree species in the park (Norway maple, little-leaf linden, honey locust, green ash, eastern white pine) accounted for $83.8 \mathrm{~kg}$ of the air pollution removed in $2012(48.2 \%) . \mathrm{O}_{3}$ removal on a per tree basis is best performed by red pine ( $721 \mathrm{~g} / \mathrm{yr}$ per tree) followed by London plane (458 g/yr per tree) and little-leaf linden (353 g/yr per tree). In terms of PM2.5 removal, Norway maple performed the best at $1.4 \mathrm{~kg} / \mathrm{yr} / \mathrm{tree}$.

\subsubsection{Storm Water Runoff Mitigation}

i-Tree Eco estimated that $2,363.45 \mathrm{~m}^{3}$ of rainfall was intercepted by Earlscourt Park trees in 2012. As with other environmental services, Norway maple trees made the largest contribution to rainfall interception $\left(789 \mathrm{~m}^{3}\right)$. It was followed by little-leaf linden $\left(250.7 \mathrm{~m}^{3}\right)$, honey locust $\left(96 \mathrm{~m}^{3}\right)$ and green ash $\left(94 \mathrm{~m}^{3}\right)$. The maximum annual rainfall interception by an individual tree was estimated for a black walnut $\left(30.2 \mathrm{~m}^{3}\right)$, where this tree had an estimated LA of $2,668 \mathrm{~m}^{2}$ and a $\mathrm{DBH}$ of $71.1 \mathrm{~cm}$.

\subsubsection{Growth Forecast}

Future growth of the park trees was forecast in terms of changes to DBH and to LA. For each of the three climate change scenarios (MIROC, NCARPCM, GFDLCM), the growth of the three tree species that had the highest importance value for year 2012 are presented, where the importance value was calculated using i-Tree Eco. i-Tree Eco calculates importance value of trees based on canopy 
cover, health and age of trees. The importance value parameter ranks species based on the ecological services they deliver. The future LA of the park was estimated with i-Tree Forecast using three approaches: (1) no future plantings; (2) plantings only to replace dead and dying ash (ending in 2017); and, replanting to both replace the dying ash trees and to continue to sustain the future urban forest of Earlscourt Park.

\subsubsection{DBH Forecast}

Average tree $\mathrm{DBH}$ is used as the primary indicator for forest growth (Figure 3.2). The MIROC scenario shows the greatest increase in average DBH. In 2012 , the average tree $\mathrm{DBH}$ of the forest was 11 inches; following the MIROC climate change scenario, which shows the most rapid increase in growing season length, the average DBH of park trees is predicted to reach 20 inches by the year 2035 . MIROC shows an average DBH of 21.8 inches for the year 2040. The average predicted tree DBH for the NCARPCM model is 18.5 inches in the year 2035, and reaches 20.2 inches in 2040. The GFDLCM model, which predicts the shortest length of growing season increase over the next 27 years, estimates the least amount of growth, where average tree DBH for the model in 2040 is 19.5 inches.

\subsubsection{Leaf Area Growth}

Leaf Area is essential for assessing the potential for delivery of ecological services (Millward \& Sabir, 2010). Norway maple, which had the highest LA of all species in the year 2012 continues to maintain high values into the future. In the climate change model that predicts the largest increase in annual growing season 


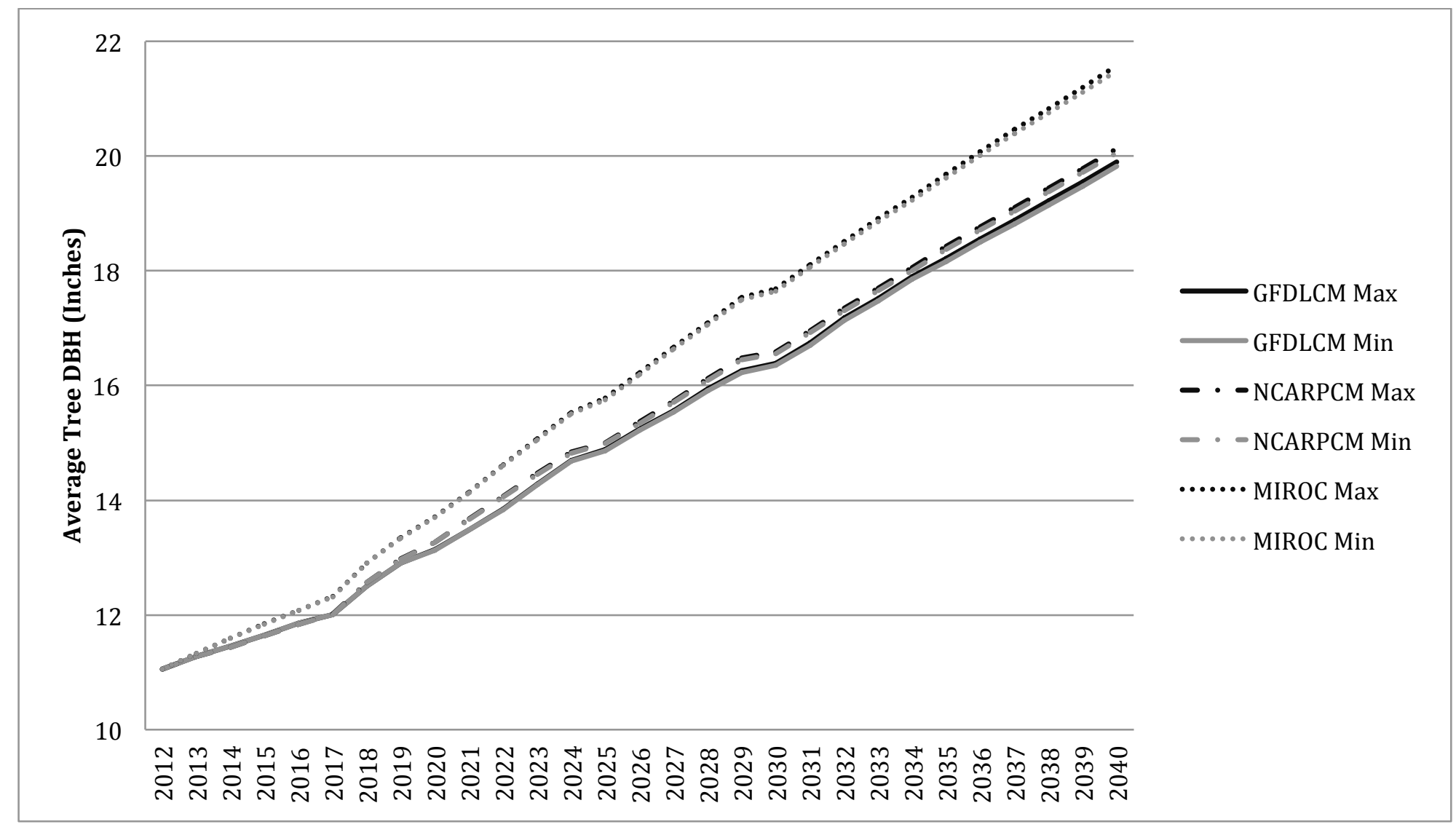

Figure 3.2: Average tree DBH (diameter at breast height, measured at $1.37 \mathrm{~m}$ above ground) projections for the three climate change models (MIROC, NCARPCM, GFDLCM) showing the impact of growing season length from 2012 to 2040. Max and min reference the tree mortality rates (1.5 and $0.7 \%$ ) used in the modeling. 


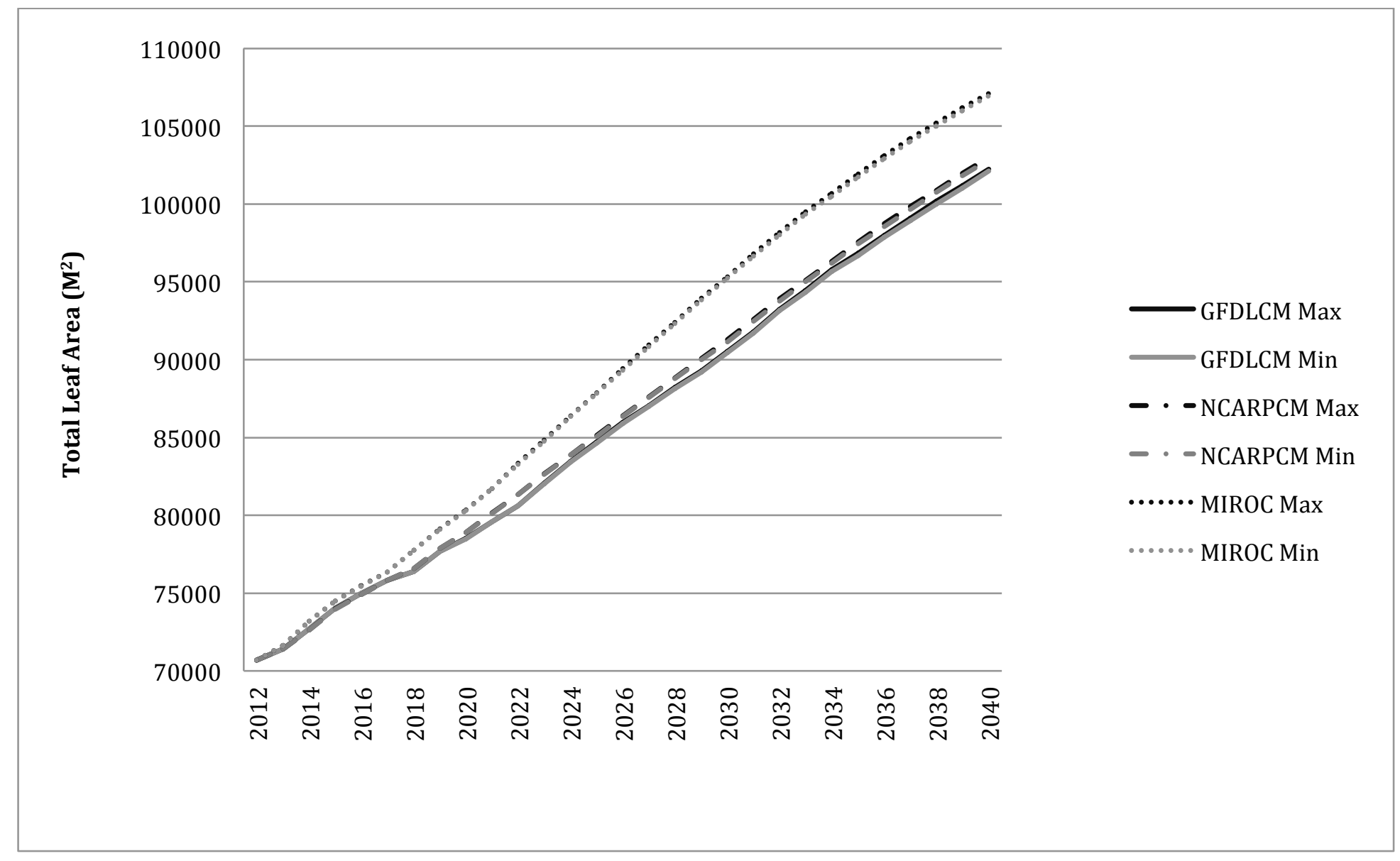

Figure 3.3: Leaf area projections for Norway maple for the three climate change scenario models (MIROC, NCARPCM, GFDLCM) from 2012 to 2040. Max and min reference the tree mortality rates $(1.5$ and $0.7 \%)$ used in the modeling. 
(MIROC), Norway maple shows substantial growth in terms of LA (Figure 3.3). Current LA for Norway maple is $70,690 \mathrm{~m}^{2}$. The MIROC simulation forecasts a LA of $90,000 \mathrm{~m}^{2}$ for Norway maple LA by the year 2027 and $107112 \mathrm{~m}^{2}$ by the year 2040. For the NCARPCM model, Norway maple is predicted to have a slower growth in LA. According to this model, Norway maple will reach a LA of $90,000 \mathrm{~m}^{2}$ by the year 2030 and $103012 \mathrm{~m}^{2}$ by the year 2040 . LA predictions based on the GFDLCM model are slightly lower than those for the NCARPCM model.

The current LA of little-leaf linden stands at $19,846 \mathrm{~m}^{2}$; in the case of littleleaf linden, all three models show fairly similar LA projections until the year 2024 (Figure 3.4); GFDLCM, NCARPCM and MIROC all present LA values between 23,900 and $24,100 \mathrm{~m}^{2}$. For MIROC, the longer growing season model, the total LA reaches $29,000 \mathrm{~m}^{2}$ in 2037 and continues to increase, where the projected LA for little-leaf linden in 2040 is $29,748 \mathrm{~m}^{2}$. The LA projections of GFDLCM and NCARPCM drop in growth in year 2024. After 2025, the LA begins to increase again for both models. In 2035, the LA for NCARPCM and GFDLCM are predicted to be 27,352 and $27,148 \mathrm{~m}^{2}$, respectively.

In the year 2012 the LA estimates for honey locust are 6,527 $\mathrm{m}^{2}$ (Figure 3.5). Projections of LA for honey locust show a trend similar to Norway maple and the earlier years of projected little-leaf linden growth (i.e., up to 2023). Until the year 2023, the MIROC model projects the highest growth in $\operatorname{LA}\left(9,619 \mathrm{~m}^{2}\right)$, followed by NCARPCM $\left(9,593 \mathrm{~m}^{2}\right)$ and GFDLCM $\left(9464 \mathrm{~m}^{2}\right)$. However, soon after the year 2025, the projections begin to change and LA starts to decrease. For NCARPCM and GFDLCM, LA projections plateau around the year 2035. In the 


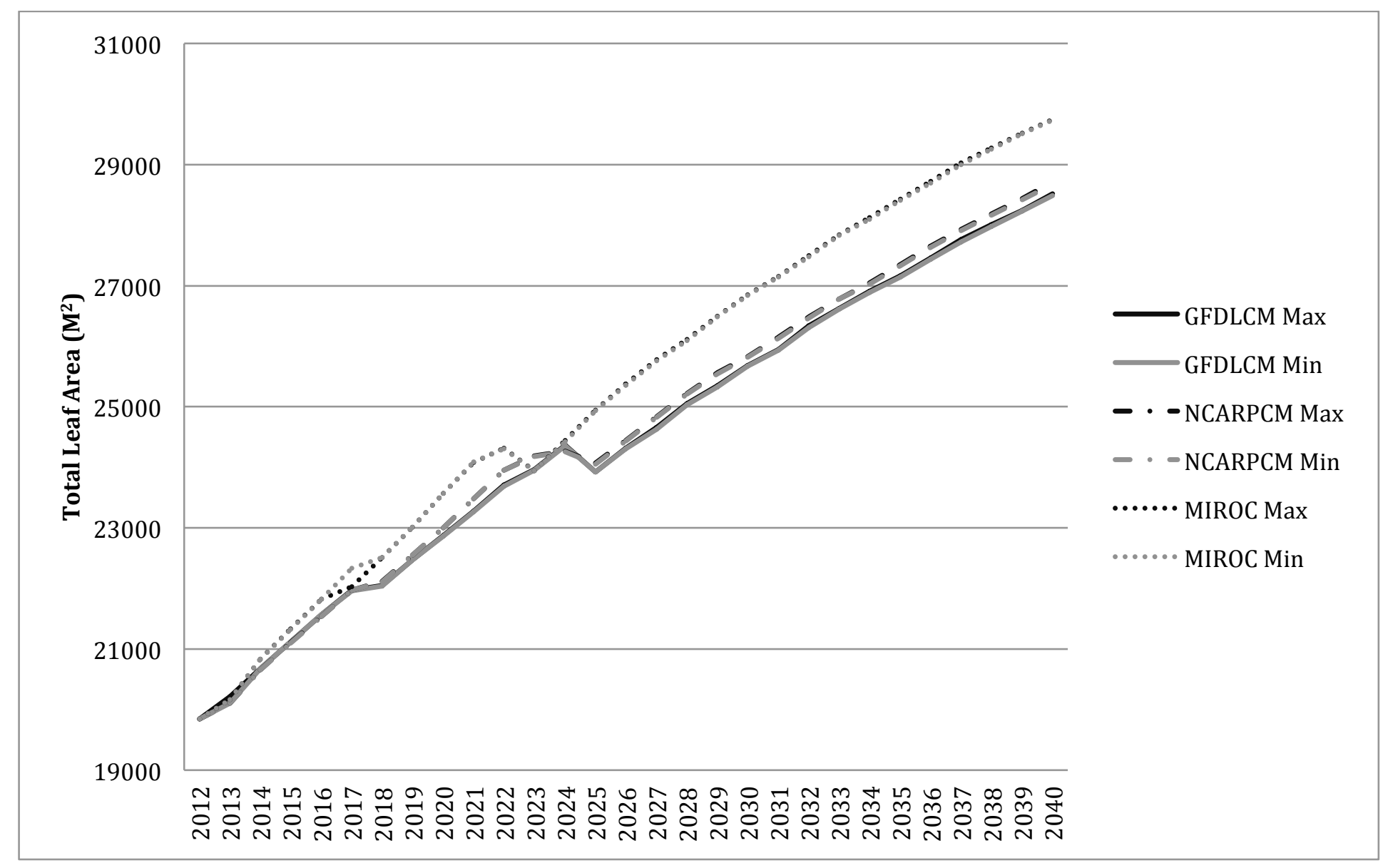

Figure 3.4: Leaf area projections for little-leaf linden for the three climate change scenario models (MIROC, NCARPCM, GFDLCM) from 2012 to 2040 . Max and min reference the tree mortality rates $(1.5$ and $0.7 \%)$ used in the modeling. 


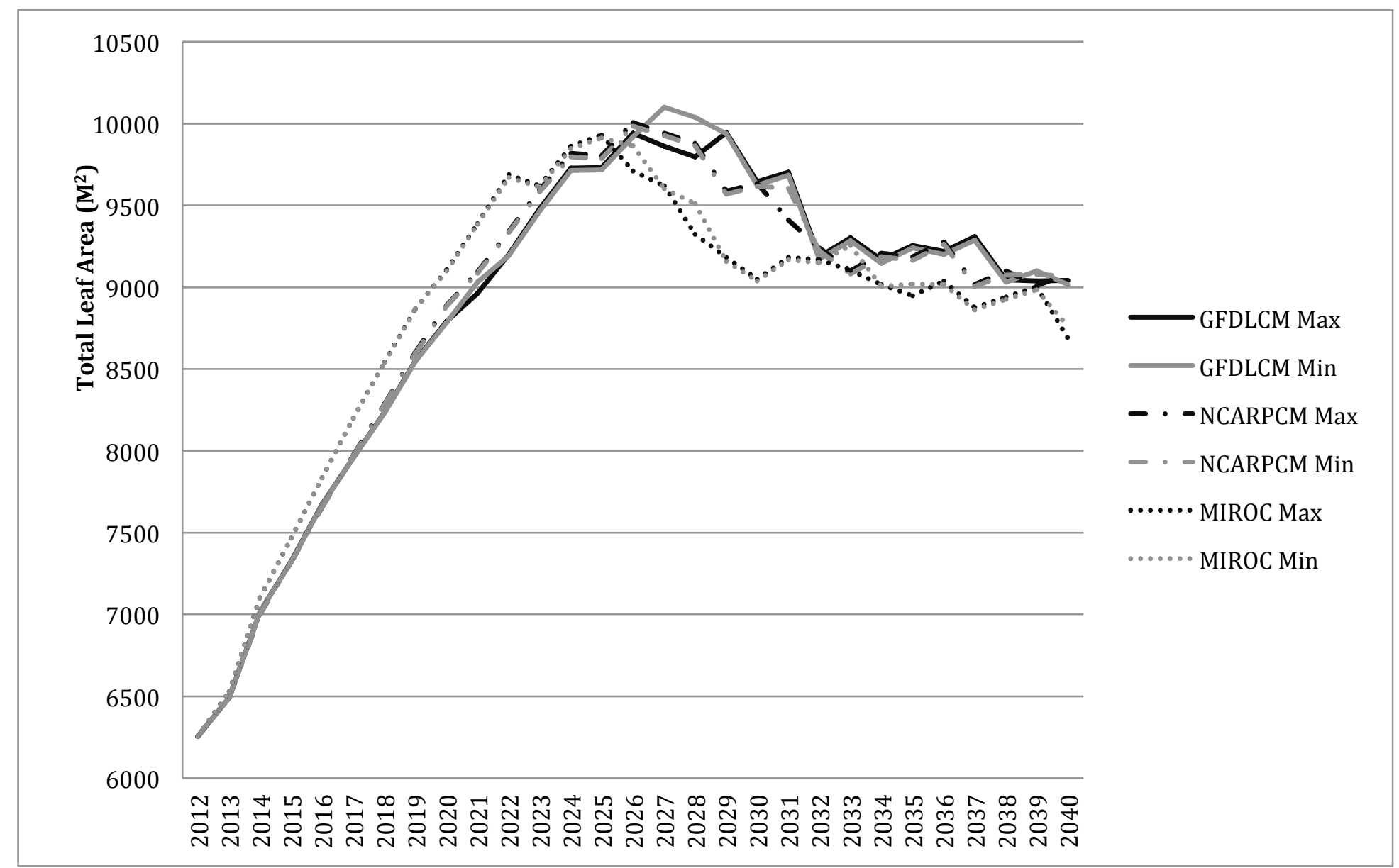

Figure 3.5: Leaf area projections for honey locust for the three climate change scenario models (MIROC, NCARPCM, GFDLCM) from 2012 to 2040. Max and min reference the tree mortality rates $(1.5$ and $0.7 \%)$ used in the modeling. 
case of MIROC, the LA projections drop further. In 2040, the final year of the projections, LA projections for MIROC are $8,687 \mathrm{~m}^{2}$, which is significantly lower.

\subsubsection{Leaf Area Comparison}

This study was designed to assume that all ash trees would die by the year 2017, as predicted by the City of Toronto (City of Toronto, 2012). However, new plantings were added in order to replace the ash population and dampen the impact of this catastrophic loss in canopy cover. In this section, leaf area predictions of trees in Earlscourt Park (following the loss of ash) are compared for the situation where replanting occurs as is outlined in section 3.3.6, and under the assumption that no trees are planted in the park following those added to replace ash. i-Tree Forecast was run with the aforementioned replanting scenario and with no new tree plantings (other than those to replace ash) for each of the three climate change models and with the maximum and minimum mortality rates. A comparison of these model simulations is presented in Figure 3.6.

The LA projections for 2018 (year after complete ash removal) using the MIROC model and including replacement plantings reach a maximum LA of $230,782 \mathrm{~m}^{2}$ (Figure 3.6a). Reviewing the projections for the same year with no replacement plantings, a maximum LA of $221,000 \mathrm{~m}^{2}$ is estimated. The projections for the NCARPCM and GFDLCM are lower than MIROC but follow the same general trend. The NCARPCM model comparison shows a maximum difference in LA of $8,791 \mathrm{~m}^{2}$ between the two scenarios. The GFDLCM model LA comparison indicates a maximum difference of $8,638 \mathrm{~m}^{2}$. The importance of ash replacement is visible in the final year (2040) of the projections as well (Figure 3.6b). In year 2040, the total LA projection by MIROC is $423,417 \mathrm{~m}^{2}, 411,744 \mathrm{~m}^{2}$ and $373,833 \mathrm{~m}^{2}$ for 

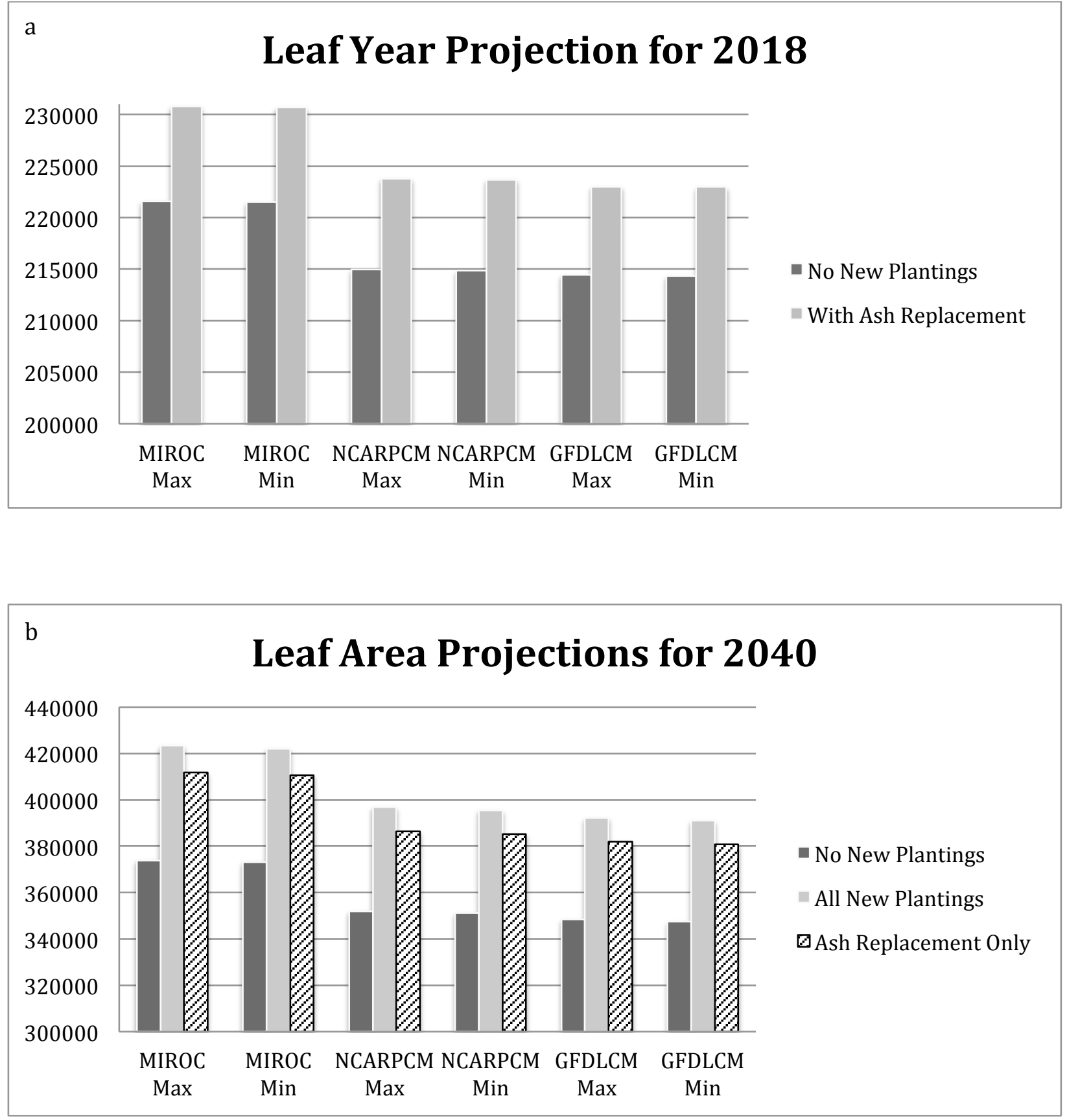

Figure 3.6: Projected leaf area difference for (a) 2018 (one year following Ash tree removal) (b) 2040 with execution of the complete replanting schedule, no new plantings, and ash replacement only, demonstrating the importance of replacing the ash trees. Max and min reference the tree mortality rates $(1.5$ and $0.7 \%)$ used in the modeling. 
the total replacement plantings scenario, ash replacement only and no replanting, respectively.

Once again, the projections for GFDLCM and NCARPCM are lower than those of MIROC but they follow the same trend. The difference between the ash replacement planting and "do nothing" scenarios is $35,209 \mathrm{~m}^{2}$ and $34,486 \mathrm{~m}^{2}$ for NCARPCM and GFDLCM models, respectively.

\subsubsection{Carbon Storage}

i-Tree Forecast model calculates carbon storage estimates of above and below ground biomass. Carbon storage projection for Norway maple, honey locust and little-leaf linden were analyzed using input from growing season length of the three climate change scenario models. Norway maple had the highest carbon storage projection of all species due to its overall abundance (Figure 3.7). As anticipated, the MIROC model estimated the greatest carbon storage values. Norway maple trees in the park were predicted to store a maximum of $141,352 \mathrm{~kg}$ of carbon by the year 2032. Storage estimates from the other two models were lower. NCARPCM estimated maximum carbon storage of $130,743 \mathrm{~kg}$ and GFDLCM $128,879 \mathrm{~kg}$ by year 2032 . This trend in carbon storage continues to grow whereby in the year 2040, the maximum carbon storage values are $167,825 \mathrm{~kg}$ (MIROC), 154,558 kg (NCARPCM) and 151,840 kg (GFDLCM).

On an average storage per species basis, little-leaf linden was estimated by the MIROC model to have the greatest carbon storage (Figure 3.8). This model predicts that little-leaf linden will store $51,682 \mathrm{~kg}$ of carbon by the year 2029 . The NCARPCM model calculates the maximum carbon storage for the species at 


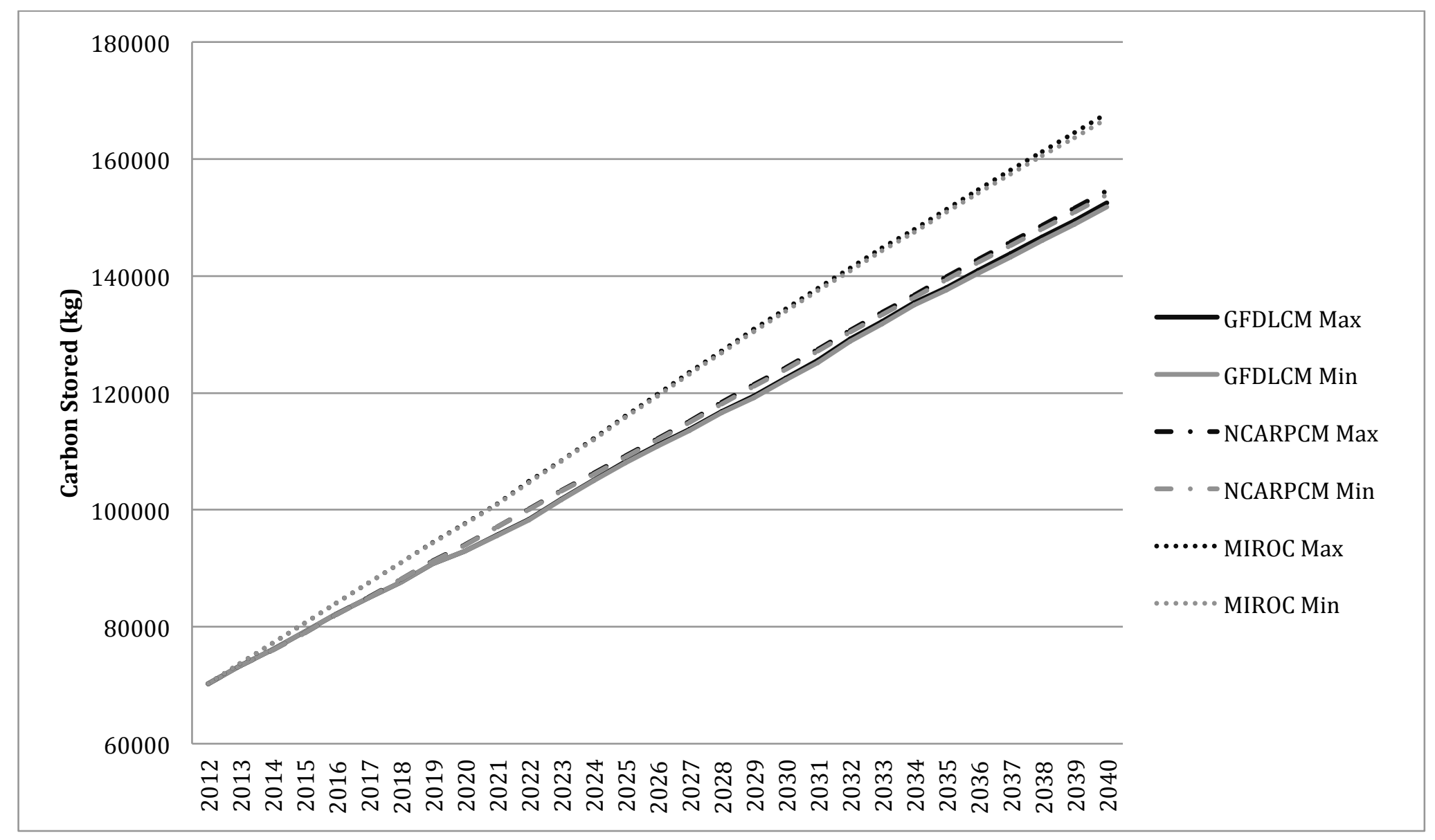

Figure 3.7: Carbon storage projections for Norway maple for the three climate change (MIROC, NCARPCM, GFDLCM) from 2012 to 2040. Max and min reference the tree mortality rates $(1.5$ and $0.7 \%)$ used in the modeling. 


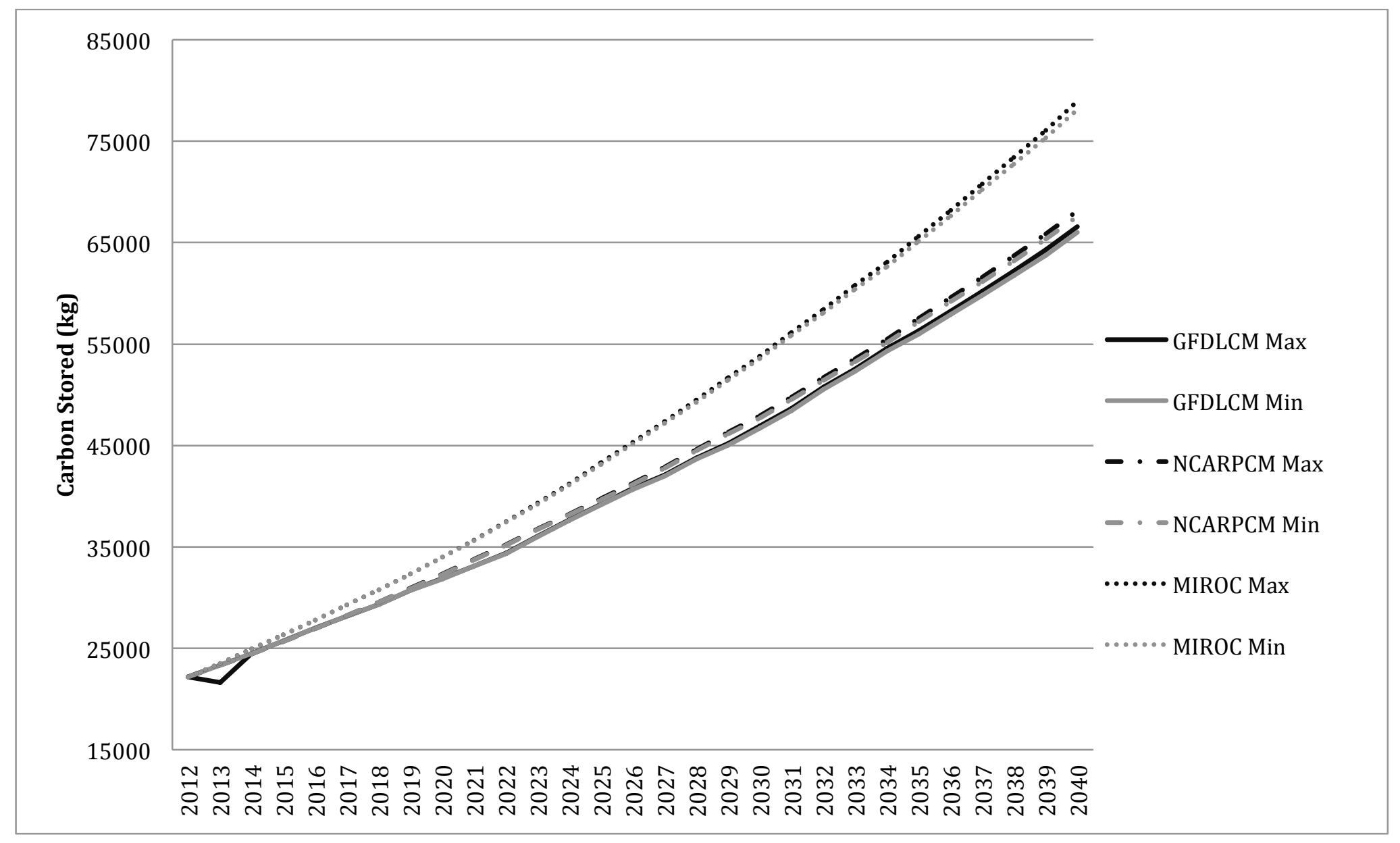

Figure 3.8: Carbon storage projections for little-leaf linden for the three climate change (MIROC, NCARPCM, GFDLCM) from 2012 to 2040. Max and min reference the tree mortality rates $(1.5$ and $0.7 \%)$ used in the modeling. 
$46,302 \mathrm{~kg}$ and $45,055 \mathrm{~kg}$ for the GFDLCM model by the year 2029. This trend continues over the length of the forecast, where in the year 2040 the maximum estimated carbon stored by little-leaf linden is $78,942 \mathrm{~kg}$ (MIROC), $68,159 \mathrm{~kg}$ (NCARPCM), and 66,002 kg (GFDLCM).

Honey locust shows a rapid increase in carbon storage for the MIROC model (Figure 3.9). The maximum carbon storage quickly moves from $20083 \mathrm{~kg}$ in the year 2014 to $60,332 \mathrm{~kg}$ in the year 2028 . The MIROC model predicts maximum carbon storage of $105,644 \mathrm{~kg}$ in 2040 . The forecast for NCARPCM calculates maximum carbon storage of $52,387 \mathrm{~kg}$ in the year 2028 and $90,049 \mathrm{~kg}$ in the year 2040. The carbon storage difference between these two models is $15,595 \mathrm{~kg}$ in the year 2040. GFDLCM estimates the smallest amount of carbon stored for all models. In 2028, the maximum carbon stored by honey locust is $50,997 \mathrm{~kg}$. In the year 2040 , the maximum storage is projected to be $87,631 \mathrm{~kg}$. This value is 2,481 $\mathrm{kg}$ less than NCARPCM and 4,031 kg less than MIROC estimates.

\subsubsection{Mortality Forecast}

In this section, general results are presented for tree mortality forecasts as well as survivorship predictions for the three most important species in the park (Norway maple, little-leaf linden, honey locust).

Average tree survivorship in Earlscourt Park drops rapidly until the year 2017, recovers for several years and then begins to decrease again, albeit not as quick a decline as between 2012 and 2017 (Figure 3.10). The trend for all models is fairly similar; however, in the case of the MIROC model, the mortality is slightly 


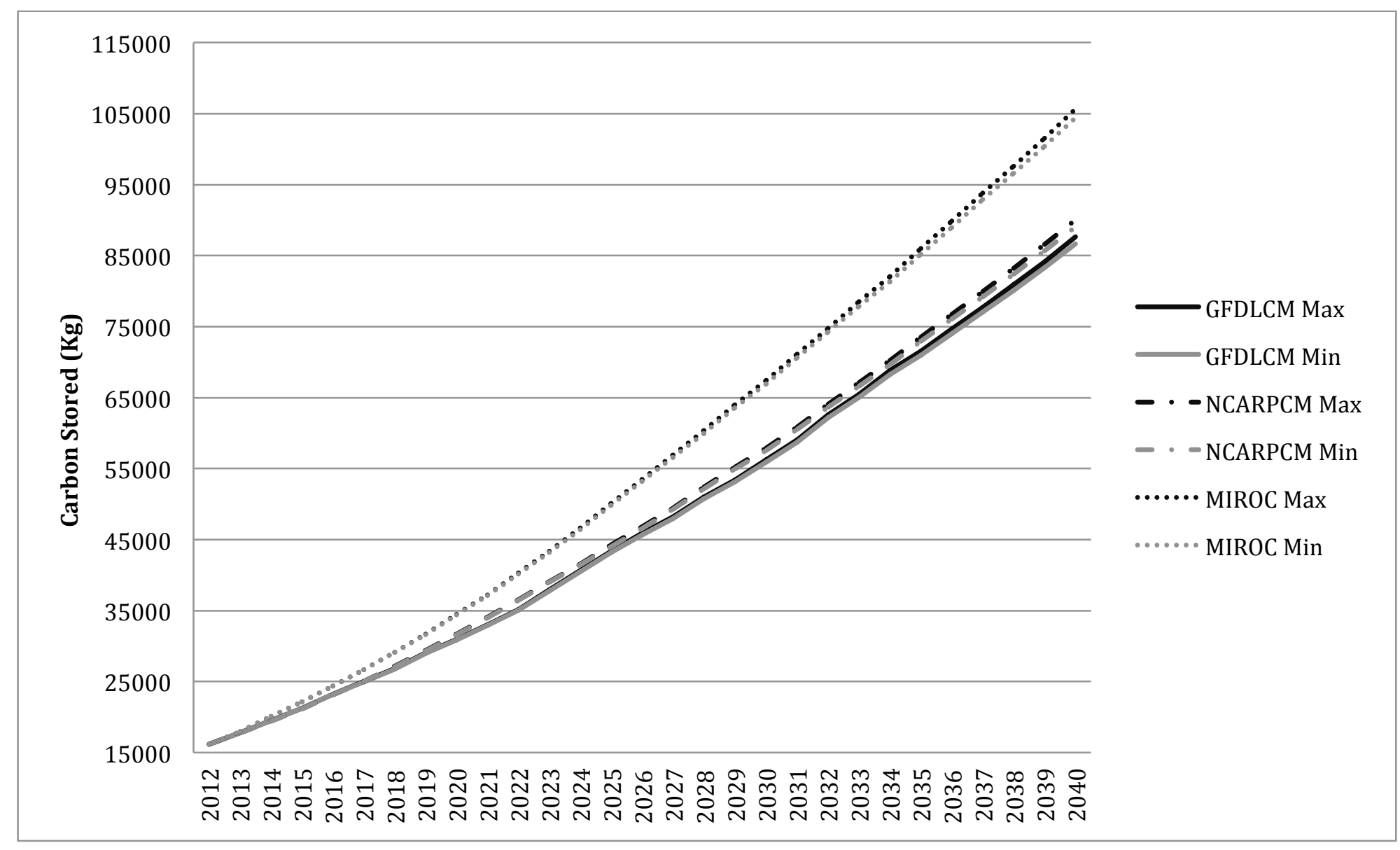

Figure 3.9: Carbon storage projections for honey locust for the three climate change (MIROC, NCARPCM, GFDLCM) from 2012 to 2040 . Max and min reference the tree mortality rates $(1.5$ and $0.7 \%)$ used in the modeling. 


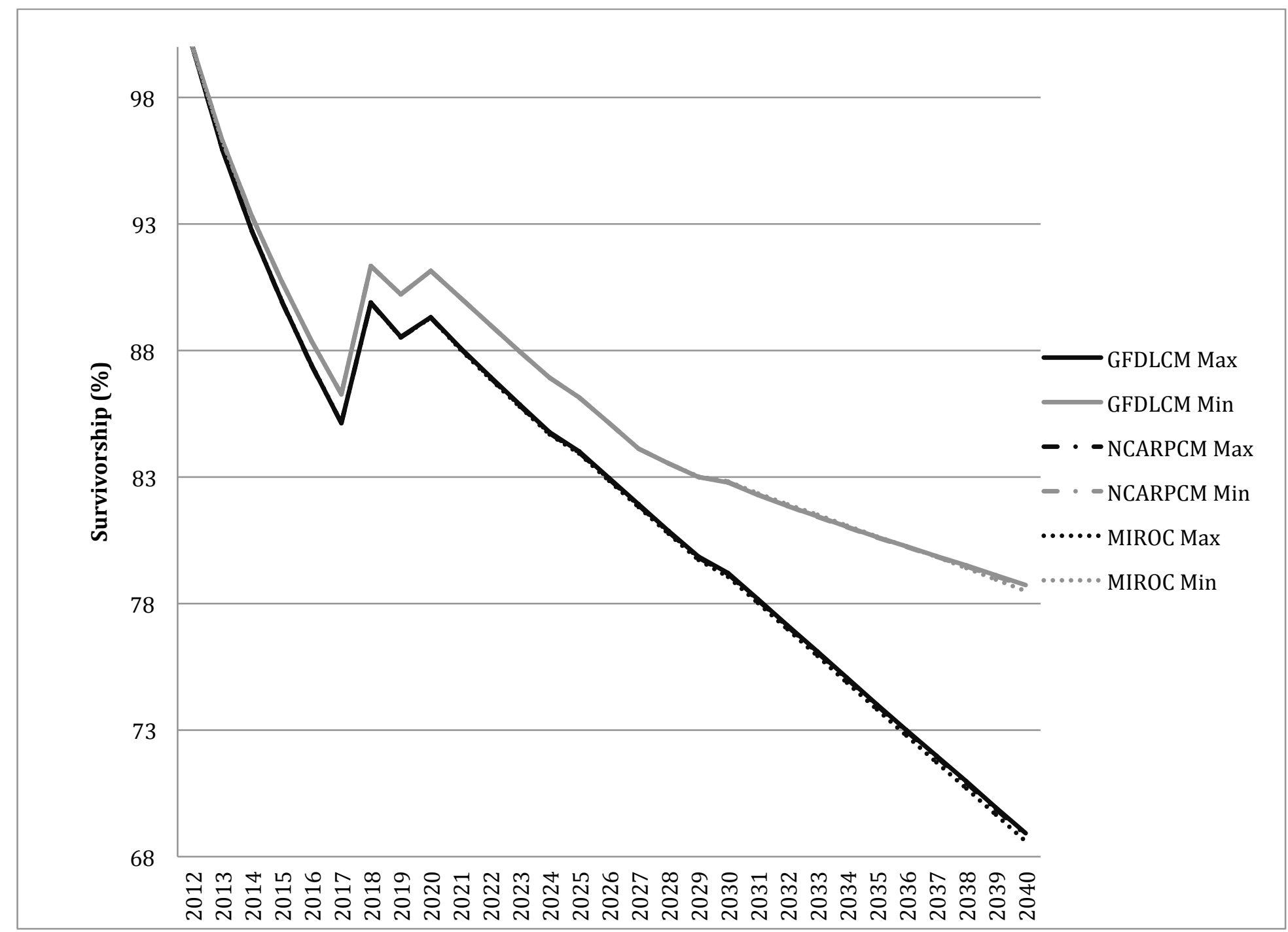

Figure 3.10: Average survival chance (\%) for Earlscourt Park tree species with MIROC, NCARPCM and GFDLCM models. Max and min reference the tree mortality rates ( 1.5 and $0.7 \%$ ) used in the modeling. 
higher in the year 2021, for the first time, MIROC model projects a different survivorship percentage in comparison to maximum of $90 \%$ projected by NCARPCM and GFDLCM. The gap becomes more distinct in the year 2035, where MIROC projects a minimum survivorship of $73 \%$ compared to the projections of $74 \%$ made by the other two models. By the year 2040 the gap grows even further, with a $1.5 \%$ maximum differential between MIROC and the two lower growing season length models, NCARPCM and GFDLCM.

The MIROC model predicts the worst survivorship for each of the three species, Norway maple, little-leaf linden and honey locust (Figure3.11a). Projections for the year 2025 show that honey locust demonstrates survivorship superiority, with a survivorship range of 87 to $89 \%$. Little-leaf linden and Norway maple both had survivorship rates of 86 to $83 \%$ and 86 to $80 \%$, respectively. A comparison of survivorship rates among species within the MICRO3.2 model shows that Norway maple has the lowest survivorship range (62 to 73\%) in the year 2040. This is followed by little-leaf linden with a survivorship range of 66 to $70 \%$, and honey locust with the healthiest survivorship range of 71 to $77 \%$, both for the year 2040. Interestingly, the lower end of the survivorship range for honey locust drops below that of little-leaf linden in 2035 when minimum survivorship is $77 \%$ for little-leaf linden and $76 \%$ for honey locust.

For the NCARPCM and GFDLCM models, which have medium to small growing season lengths, the trajectory of mortality rates is less steep, meaning that under the less extreme climate change scenarios higher chances of tree survival are likely. When the three tree species are compared (Figures 3.11a through c), 

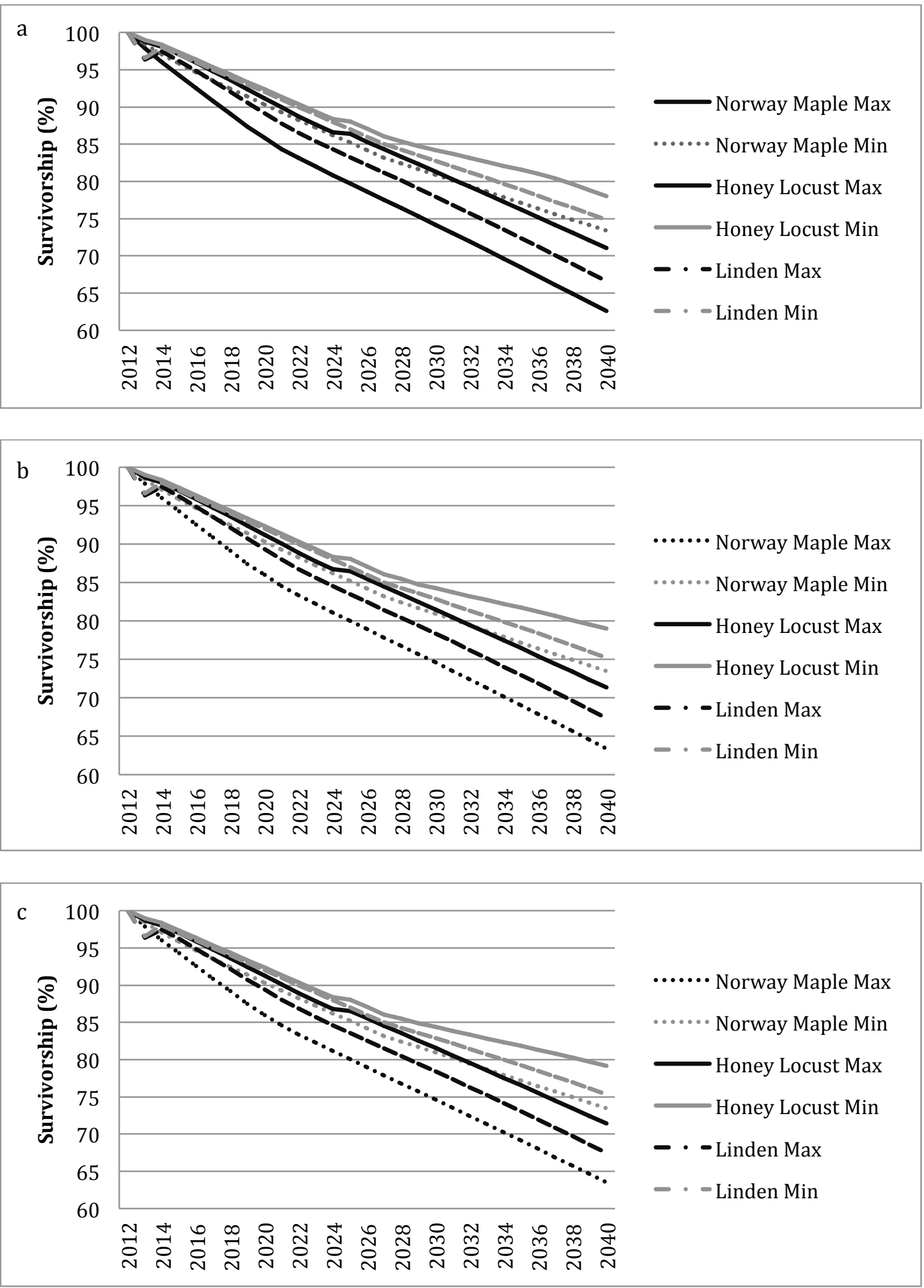

Figure 3.11: Species-specific average survivorship (\%) for Earlscourt Park trees assuming length of growing season based on (a) MIROC, (b) NCARPCM, and (c) GFDLCM. Max and min reference the tree mortality rates (1.5 and $0.7 \%)$ used in the modeling. 
they follow the same inter-species trend concerning survivorship as what was seen with the MIROC model. In 2040, survivorship was predicted as follows: Norway maple (63-74\%), little-leaf linden (67-75\%) and honey locust (71-79\%). The survivorship range for both NCARPCM and GFDLCM was the same. Similar to the MIROC model, the lower range of honey locust survivorship drops below that of the little-leaf linden at the year 2035. In all three models, Honey locust has the greatest overall rate of survivorship, followed by little-leaf linden, with Norway maple predicted to have the highest mortality.

\subsection{Discussion}

The length of growing seasons change with the long-term climate of a region, making it necessary to model dynamic growing season lengths. Despite the differing IPCC storylines, the GFDLCM and NCARPCM models predict similar results for growing season length. For example, the projected average length of growing season for NCARPCM, over the 28-year forecast, is only 6 days longer than that of GFDLCM. On the other hand, the MIROC model displayed a major change in length of growing season; however, this extreme climate model doesn't appear to curtail growth of the park trees. The longer growing season leads to a faster growth of trees, which resulted in a larger prediction of LA and canopy cover. These increases in LA will serve to expand the delivery of ecological services, and can serve to provide greater amelioration of air pollution and increases in carbon sequestration (Nowak \& Crane, 2002; Nowak \& Walton, 2006). It may also lead to better storm water management and conservation of energy by shading buildings that are in close proximity to the park (Akbari et al, 2001; Grapentine, 2008). 
As has been established in the literature, LA is the most important driver of the ecological services provided by trees (Peper et al., 2001a). In an urban park with relatively high species richness, such as Earlscourt Park, variability in LA among species is an important line of inquiry. By using LA projections based on the three climate change models, canopy growth of Norway maple, little-leaf linden and honey locust is projected from 2012 through 2040. In the case of Norway maple, LA increases at a higher rate for the MIROC climate change scenario (longest growing season) when compared with the NCARPCM and GFDLCM models. The longer growing season available in the MIROC model in combination with the fast growing ability of Norway maple leads to dominance of this species concerning ecological service provision. Despite that value of the ecological services Norway is projected to deliver, it is an exotic species that has the ability to competitively exclude other species in the park (Webster et al., 2005; Bertin et al., 2005). The rapid increase in Norway maple LA is not seen with the other two climate change scenarios having smaller growing season lengths.

Although a higher LA is projected for little-leaf linden in the MIROC model when compared with other models, LA increases at a consistent rate throughout the projection. In the case of a longer growing season this species grows at a slightly higher rate, but it is unlikely that it would outcompete other park trees. The consistent and predictable growth of the little-leaf linden makes it well adapted for growing in parks. Overall, the little-leaf linden's rate of growth for NCARPCM and GFDLCM is lower compared to MIROC as the former two models have a smaller growing season length. 
Honey locust shows perhaps the most interesting LA growth pattern of the three tree species, and across all climate change scenarios. It grows rapidly increasing LA under each climate model scenario until the year 2024. Following 2024, growth in honey locust LA decreases for all models until the year 2034. At this point in time, LA growth stabilizes for NCARPCM and GFDLCM, but continues to decrease for MIROC. Honey locust is an excellent street tree because it is resistant to many of the hardships of urban living including de-icing salt and heavily compacted soil. However, it is largely intolerant of competition, especially for light (Carpenter et al., 1974). It also has an indeterminate growth pattern (i.e., produces leaves at regular intervals during the growing season), further adding to the difficulty of predicting its growth (Boyce, 1938). Hence, when the growing season becomes longer and LA for other more dominant species increases, the growth rate of honey locust is retarded due to its intolerance of shade. In the case of the MIROC model, where the length of growing season is significantly longer and dominant species such as Norway maple grow faster, the impact on native species such as honey locust is evident. The projections show that although honey locust is a fast growing species, it is not the most ideal fit in a park dominated by maples and other taller species, whose dense and spreading canopies shade the honey locust and inhibit its growth.

It is interesting to observe the effect on LA across the entire park when dying ash trees are not replaced. At present, Ash is one of the most abundant species in the park, and causes a major gap in the canopy when not replaced Because newly planted trees (i.e., with a DBH of $10 \mathrm{~cm}$ ) will have much smaller LA measurements early in their life; replacement trees were introduced into the model 
prior to the year 2017 (the estimated time of complete collapse of the ash population). When the no-replanting scenario is compared with the annual replanting scenario proposed in this project, it is evident that the early attention to replanting of different tree species can provide an important buffer against the loss of LA and the subsequent loss of ecological services. Specifically, the planting schedule adopted in this research project shows that if replacement plantings were made after the death of ash trees, there would be a large loss in the ecological services provided by the park trees. New plantings take time to mature and therefore, this loss can be compensated through early plantings of fast growing species that are generally tolerant of urban conditions (e.g., honey locust, black locust, freeman maple).

Average tree DBH in Earlscourt Park almost doubled from 11 to 21 inches (MIROC) and 11 to 20 inches (NCARPCM \& GFDLCM) over the span of the 28year forecast. With most species maturing at a much higher DBH than was recorded during the 2011 survey, these results suggest that the overall age structure of trees in the park is sound. Because DBH is directly related to the growth of a tree, the near doubling of DBH shows evidence of an age structure that will deliver sustainable ecological benefits for years to come. It also represents a cautionary tale concerning the requirement for regular replanting of young trees so that the park's forest does not become over mature. Millward \& Sabir (2010) demonstrate that Allan Gardens, another downtown Toronto park, has a forest age structure dominated my mature trees, a circumstance whereby major losses of ecological benefits are likely to occur with the death of older trees and few middle aged trees poised to replace them. 
Carbon storage, which is directly related to above and below ground biomass of the tree, increases for all species in all models in a consistent manner. In all cases, carbon storage was higher for the MIROC model, a finding that was anticipated due to the longer growing season. It is worth noting that the carbon storage values for little-leaf linden and honey locust increase at higher rates than those of Norway maple. This is due to the fact that Norway maple trees in Earlscourt Park are mostly older when compared to other tree species. Given that Norway maple is no longer on the City of Toronto tree planting list (partly owing to its invasive status), no new plantings of this species were considered in this project. Therefore, because the growth rate of trees is faster at a younger age, the linden and locust populations increase their stored carbon more rapidly than Norway maple.

The overall maximum and minimum survivorship of the park based on the mortality models shows similar projections for NCARPCM and GFDLCM models. This is due to the similar growth rate of the population in both the models. However in the case of MIROC model the survivorship dropped. Since MIROC projects longer growing seasons leading to a faster growth of the tree, increasing the $\mathrm{DBH}$ at a higher rate than in other models. i-Tree Forecast model relates mortality with specific DBH classes for medium small and large trees, this leads to a faster mortality rate of trees with higher $\mathrm{DBH}$, as seen in MIROC.

When considering survivorship, Norway maple displays the highest mortality rate. Considering that most urban foresters now view Norway maple as a problematic tree (e.g., weak branching structure, invasive in natural areas) (Webster et al., 2005), its higher mortality rate might be considered beneficial to 
the survival of native species. The primary reason for the high mortality rate is fast growth rate of the species and the mature age structure of the population in combination with no recent or future plantings (i.e., Norway maple was not included in this projects replanting scenario). In spite of this, Norway maple is delivering an appreciable proportion of the ecological benefits flowing from Earlscourt Park, a fact that must be embraced when prioritizing future planting timing and numbers of trees.

Of the three park species having the highest importance values concerning service delivery, honey locust has the best survival rate until the year 2030; following this date it has a lower survivorship rate that little-leaf linden. This change in survivorship trajectory can be explained by a reduction in LA for honey locust occurring at the same time as this increase in tree mortality. Additionally, other factors indicate that future plantings of honey locust in Earlscourt Park may not be ideal. The intolerance of honey locust to competition for light, which is projected to increase during this time period due to new plantings, and a general expanding canopy will lower its survivorship and LA. It is important to note that there are 12 projected replantings of honey locust (9 in year 2014 and 3 in 2034). The fact that the survivorship for the honey locust is still forecast to drop below that of the littleleaf linden, despite these plantings, is further evidence that honey locust may not be the best park tree when there is competition for light.

The results of this study reveal the general growth trajectories for each of the three tree species under specific climate change scenarios. Little-leaf linden was the most stable (LA, carbon storage, survivorship) of the three species, making it worthy of specific future care and maintenance. The reliable 
characteristics of the species means that ecological services associated with biomass and LA, like carbon storage, air pollution avoidance will continue to flow (Nowak \& Crane, 2002; Millward \& Pothier, 2013). The consistent increase in LA and canopy means that the neighboring residential and commercial buildings will also keep receiving energy saving benefits, which might increase in importance in scenarios with longer growing season caused by warmer climate (Akbari et al, 2001). It should be noted that little-leaf linden was not selected as a tree for future replanting in the model because it is not native to the Toronto region, and was, therefore, not listed as a recommended tree by LEAF.

The future of Norway maple appears to be one of the more varied based upon the MIROC model, but shows greater stability in GFDLCM and NCARPCM models. In the MIROC model the longer growing seasons are leading to faster growth of the species, which might lead to near term domination of the Norway maple in the canopy due to its aggressive growth and ability to outcompete other species. However, dominance of the Norway maple is likely to be short lived as it does not generally have a long lifespan and is not likely to be replanted in the park. Because the Norway maple population contributes so much currently in the way of ecological benefits, yet its future life span is limited, planners need to prepare carefully concerning strategic replacement of this species, a scenario not dissimilar to that need to address the ash tree.

Long-term management strategies suggested by Morgan (1991) and Kenney et al. (2010) could be applied to the park. For example, Kenney et al. (2010) present a long-term management scheme with a 20-year strategy. They divide 20 years into four 5-year management plans and 20 annual operating plans. 
Morgan (1991) suggests a strategic plan, which includes surveys, review, monitoring, analysis and review, and calls for strong community involvement for such an approach to be successful. At present, the City of Toronto has a number of short-term replanting plans for park trees, but no long-term strategies (City of Toronto, 2013). Consistent monitoring of the health of older trees and of species with higher mortality rates can assist staff to prepare for replacement plantings.

\subsection{Conclusion}

This study uses i-Tree Eco to model and document the current urban forest structure and function of Earlscourt Park, Toronto. With these baseline forest conditions, the project then uses the new i-Tree Forecast modeling procedure to predict tree growth and mortality from 2012 through 2040 using three climate change scenarios as well as varying mortality rates and a future park replanting plan. Tree survivorship and LA were evaluated as primary indicators for the performance, growth and health of the study park's urban forest.

The methodological approach developed in this study can provide policy makers and management teams with a tool that allows them to evaluate growth trajectories for a treed urban park and further provides a means by which future outcomes can be varied based upon climate scenarios, mortality rates and replanting initiatives. Furthermore, there is latitude in the approach used in this project to flag trees that are vulnerable, whether due to lower chances of survival or marginal LA values. The approach taken in this project could be used to assist park managers select the most appropriate combination of species and numbers of trees to replant so that a sustainable flow of ecological services can be maintained. 
This information also helps community groups and environmental NGOs in their efforts to secure funding and strengthen their mandates. As climate change models from three different IPCC storylines were used, planners have latitude to focus their efforts on the most suitable projections depending on their view of the most likely economic, social and environmental future.

\subsection{References}

Akbari, H., Pomerantz, M., \& Taha, H. (2001). Cool surfaces and shade trees to reduce energy use and improve air quality in urban areas. Solar Energy, 70(3), 295-310.

Alvey, A. A. (2006). Promoting and preserving biodiversity in the urban forest. Urban Forestry \& Urban Greening, 5(4), 195-201.

Bertin, R. I., Manner, M. E., Larrow, B. F., Cantwell, T. W., \& Berstene, E. M. (2005). Norway maple (acer platanoides) and other non-native trees in urban woodlands of central massachusetts. Journal of the Torrey Botanical Society, 132(2), 225-235.

Boyce, J. (1938). Forest pathology. New York \& London: McGraw-Hill.

City of Toronto. (2013). Urban forestry. Retrieved July/23, 2013, from http://www.toronto.ca/trees/

Chen, W. Y., \& Jim, C. Y. (2008). Assessment, and valuation of the ecosystem services provided by urban forests. in: Carreiro, M., Y. song and J. wu (eds), Ecology, Planning, and Management of Urban Forests International Perspectives, 53(1).

Dwyer, J.F., Nowak, D.J., Noble, M.H., Sisinni, S.M., (2000). Connecting people with ecosystems in the 21st century, an assessment of our nation's urban forests. General Technical Report, PNW-GTR-490. USDA Forest Service, Pacific Northwest Research Station, Portland OR, p. 483.

Frelich, L. E. (1992). Predicting dimensional relationships for twin cities shade trees. University of Minnesota - Twin Cities 
Gómez-Baggethun, E., \& Barton, D. N. (2013). Classifying and valuing ecosystem services for urban planning. Ecological Economics, 86, 235-245.

Grapentine, L., Rochfort, Q., \& Marsalek, J. (2008). Assessing urban stormwater toxicity: Methodology evolution from point observations to longitudinal profiling. Water Science and Technology, 57(3), 1375.

GreenHere. (2013). GreenHere: Community reforestation and greening initiatives. Retrieved August/10, 2013, from http://www.greenhere.ca/index.html

Groombridge, B., \& Jenkins, M. (2002). World atlas of biodiversity earth's living resources in the 21st century. Berkley, CA: University of California Press.

i-Tree. (2012). What is i-tree? Retrieved June/15, 2013, from http://www.itreetools.org/index.php

Jansson, M., \& Lindgren, T. (2012). A review of the concept 'management' in relation to urban landscapes and green spaces: Toward a holistic understanding. Urban Forestry \& Urban Greening, 11(2), 139-145.

Jim, C. Y., \& Liu, H. T. (2001). Species diversity of three major urban forest types in guangzhou city, china. Forest Ecology and Management, 146(133), 99.

Lawrence, A. B., Escobedo, F. J., Staudhammer, C. L., \& Zipperer, W. (2012). Analyzing growth and mortality in a subtropical urban forest ecosystem. Landscape and Urban Planning, 104(1), 85-94.

McKinney, M.L., (2006). Urbanization as a major cause of biotic homogenization. Biological Conservation 127, 247-260.

McLean, D., Ryan, J., \& Hurd, A. (2007). Seeing the urban forest through the trees: Building depth through qualitative research. Arboriculture and Urban Forestry, 33(1), 308.

McPherson, E. G., Simpson, J. R., Peper, P. J., Gardner, S. L., Vargas, K. E., Maco, S. E., \& Xiao, Q. (2006). Piedmont community tree guide: Benefits, costs, and strategic planting. ( No. PSW-GTR-200).USDA Forest Service General Technical Report.

McPherson, G., \& Peper, P. (2012). Urban tree growth modeling. Arboriculture and Urban Forestry, 38(5), 172-180.

McPherson, G., Simpson, J. R., Peper, P. J., Maco, S., \& Xiao, Q. (2005). Municipal forest benefits and costs in five US cities Journal of Forestry, 103(8), 411-416. 
McPherson, E. G. (1999). In Simpson J. R., Pacific Southwest Research Station (Eds.), Carbon dioxide reduction through urban forestry: Guidelines for professional and volunteer tree planters. Albany, Calif.: U.S. Dept. of Agriculture, Forest Service, Pacific Southwest Research Station.

Millward, A. A., \& Sabir, S. (2010). Structure of a forested urban park: Implications for strategic management. Journal of Environmental Management, 91(11), 2215-2224.

Millward, A. A., \& Sabir, S. (2011). Benefits of a forested urban park: What is the value of allan gardens to the city of toronto, canada? Landscape and Urban Planning, 100(3), 177-188.

Morgan, G., 1991. A Strategic Approach to the Planning and Management of Parks and Open Spaces. The Institute of Leisure \& Amenity Management, Berkshire.

Morrison, H. J. (2008). Land cover distribution and change in toronto, ontario, canada from 1985-2005. (Unpublished Master of Spatial Analysis). Ryerson University,

Nakicenovic, N., Alcamo, J., Davis, G., de Vries, B., Fenhann, J., Gaffin, S., Dadi, Z. (2000). Special report on emission scenerios . (Special Report No. 1). Cambridge, United Kingdom: Intergovernmental Panel on Climate Change. . (IPCC Special Report)

Nikoofard, S., Ugursal., V. I., \& Beausoleil-Morrison, I. (2011). Effect of external shading on household energy requirement for heating and cooling in canada. Energy \& Buildings, 43(7), 1627-1635.

Nowak, D. J., Kuroda, M., \& Crane, D. E. (2004). Tree mortality rates and tree population projections in baltimore, maryland, USA. Urban Forestry \& Urban Greening, 2(3), 139-147.

Nowak, D. J., \& Walton, J. (2006). Projected urban growth (2000-2050) and its estimated impact on the US forest resource Journal of Forestry, 103(8), 383.

Nowak, D. J. (2012). Contrasting natural regeneration and tree planting in fourteen north american cities. Urban Forestry \& Urban Greening, 11(4), 374-382.

Nowak, D. J., \& Crane, D. E. (2002). Carbon storage and sequestration by urban trees in the USA. Environmental Pollution, 116(3), 381-389. 
Nowak, D. J., Greenfield, E. J., Hoehn, R. E., \& Lapoint, E. (2013). Carbon storage and sequestration by trees in urban and community areas of the united states. Environmental Pollution, 178(7), 229-236.

Pachauri, R., \& Reisinger, A. (2007). Climate change 2007: Synthesis report. contribution of working groups I, II and III to the fourth assessment report of the intergovernmental panel on climate change. (No. 4). Geneva, Switzerland: Intergovernmental Panel of Climate Change. Retrieved from http://www.ipcc.ch/pdf/assessment-report/ar4/syr/ar4_syr.pdf

Peper, P., McPherson, G., \& Mori, S. (2001). Predictive equations for dimensions and leaf area of coastal southern california street trees. Journal of Arboriculture 27(4): July 2001, 27(4), 169.

Peper, P., McPherson, G., \& Mori, S. (2001b). Equations for predicting diameter, height, crown width and leaf area of san joaquin valley street trees. Journal of Arboriculture 27(4): July 2001, 27(4), 169.

Peper, P. J., \& McPherson, E. G. (2003). Evaluation of four methods for estimating leaf area of isolated trees. Urban Forestry \& Urban Greening, 2(1), 19-29.

Puppim de Oliveira, J. A., Balaban, O., Doll, C. N. H., Moreno-Peñaranda, R., Gasparatos, A., lossifova, D., \& Suwa, A. (2011). Cities and biodiversity: Perspectives and governance challenges for implementing the convention on biological diversity (CBD) at the city level. Biological Conservation, 144(5), 1302-1313.

Randrup, T. B., \& Persson, B. (2009). Public green spaces in the nordic countries: Development of a new strategic management regime. Urban Forestry \& Urban Greening, 8(1), 31-40.

Roloff, A., Korn, S., \& Gillner, S. (2009). The climate-species-matrix to select tree species for urban habitats considering climate change. Urban Forestry \& Urban Greening, 8(4), 295.

Sawka, M., Millward, A. A., Mckay, J., \& Sarkovich, M. (2013). Growing summer energy conservation through residential tree planting. Landscape and Urban Planning, 113, 1-9.

Semenzato, P., Cattaneo, D., \& Dainese, M. (2011). Growth prediction for five tree species in an italian urban forest. Urban Forestry \& Urban Greening, 10(3), 169-176. 
Seto, K. C., Sánchez-Rodríguez, R., \& Fragkias, M. (2010). The new geography of contemporary urbanization and the environment. Annual Review of Environment and Resources, 35(1), 167-194.

Tait, C.J., Daniels, C.B., Hill, R.S., (2005). Changes in species assemblages within the Adelaide metropolitan area, Australia,1836-2002. Ecological Applications 15(2), 346-359.

Troxel, B., Piana, M., Ashton, M. S., \& Murphy-Dunning, C. (2013). Relationships between bole and crown size for young urban trees in the northeastern USA. Urban Forestry \& Urban Greening, 12(2), 144-153.

Webster, C. R., Nelson, K., \& Wangen, S. R. (2005). Stand dynamics of an insular population of an invasive tree, acer platanoides. Forest Ecology and Management, 208(1-3), 85-99.

Welch, J. M. (1994). Street and park trees of boston: A comparison of urban forest structure. Landscape and Urban Planning, 29(2-3), 131-143.

White, M. A., Running, S. W., \& Thornton, P. E. (1999). The impact of growingseason length variability on carbon assimilation and evapotranspiration over 88 years in the eastern US deciduous forest. International Journal of Biometeorology, 42(3), 139-145. 


\section{Chapter 4}

\subsection{Abstract}

i-Tree Streets analyzes the leaf area of street trees based on two user inputs, diameter at breast height (DBH) and species type. The Streets model then uses these two parameters with a regionally specific look-up table of trees to estimate a tree's leaf area and associated ecological services. This approach is questionable in cases with extreme canopy conditions (i.e., degraded or very healthy) because leaf area (LA) is the primary driver of ecological services delivered by a tree. i-Tree Eco, on the other hand, requires multiple user inputs describing a tree's condition. Through a leaf area estimate comparison and correlation analysis of i-Tree Streets and Eco, the importance of detailed canopy data input for leaf area calculations is demonstrated. Users contemplating these tools should be aware of the tradeoff between ease of data collection and model accuracy, especially in the case of estimating benefits for individual trees.

Keywords: Leaf Area, i-Tree Eco, i-Tree Streets. 


\subsection{Introduction}

The majority of municipal urban forestry teams in North America use similar management approach across all trees in their jurisdiction (City of Toronto, 2013; City of Boston, 2013). However, the growth rate of trees, and their associated ecological benefits, are not likely to be the same for street trees and those growing in urban parks. Millward and Sabir (2010) argue this point in their study of a forested urban park where they use i-Tree STRATUM (now Streets) to model tree benefits. In the present research note, leaf area (LA) estimates provided by the two $\mathrm{i}$-Tree tools, Streets and Eco, are compared using data from the same treed urban park, Earlscourt Park in Toronto, Canada. The purpose of this project is to reenforce the need to have separate strategies for assessing tree benefits based on tree location and on the desire for accurate tree-specific estimates of ecological service delivery.

$\mathrm{i}$-Tree is a peer reviewed software suite developed by the USDA Forest Service that is used for urban forestry analysis and tree benefit assessments (itree, 2012). Many recent studies have used $\mathrm{i}$-Tree Streets for conducting full inventories of trees and estimating their associated ecological services (Martin et al., 2011; Pothier et al., 2012). Only in the last several years were users able to use i-Tree Eco to conduct a complete inventory of trees in a particular location (e.g., an urban park) and estimate individual tree contributions of ecological services. While developed for use in the USA, i-Tree Streets and Eco have been since been used for analyzing urban forest benefits across the world for various urban land use types (McPherson, 2010). For example, Millward \& Sabir (2011) used the precursor to i-Tree Streets (STRATUM) to calculate the ecological 
benefits of trees growing in Allan Gardens, Toronto. Pothier \& Millward (2012) used i-Tree Eco for their study of the trees on a downtown Toronto institutional property. $\mathrm{i}$-Tree Streets uses $\mathrm{DBH}$ and tree species along with the geographic region in which a tree is growing to estimate LA (McPherson, 2000). In contrast, i-Tree Eco, requires a much more detailed set of tree inventory data to perform the same task. In addition to $\mathrm{DBH}$ and tree species, Eco requires the inventory provide detail on crown measurement and light exposure (Nowak \& Crane, 2008; Troxel et al., 2013). Furthermore, Eco uses hourly pollution and weather data to generate its ecological service predictions. Streets, on the other hand, draws on data compiled from 16 different climate regions across North America to define length of growing season and attribute specific meteorological characteristics to the location in which the measured tree is growing ( $\mathrm{i}-$ Tree, 2012). It is well documented that LA is one of the most important indicators of the ecological benefits provided by urban trees (Peper et al., 2001; Millward \& Sabir, 2010). The purpose of this research note is to compare the LA estimates produced by the two tools (Streets and Eco) using a correlation analysis. Differences between the model estimates are expected to provide guidance for urban forestry planners and community groups when selecting a model for a specific project application.

\subsection{Methodology}

The tree inventory data were collected for Earlscourt Park, Toronto in the summer of 2012. The data were collected under the i-Tree Eco protocol and was then processed for both Eco and Streets. The primary difference between the two modules is that Eco protocol requires detailed canopy, weather and pollution data 
in addition to the DBH and species information that is used by Streets. Earlscourt Park is located amongst mixed residential and commercial land use zoning. The park is bounded on all sides by major streets. The park had a total of 601 trees in 2012 that met or exceeded a DBH threshold of $6 \mathrm{~cm}$. Of this total tree population, 328 have open growing canopies with ample light exposure on all sides. Because iTree Streets was designed specifically for street trees, which are assumed to have light exposure from a minimum of 4 sides, the present study only compared results obtained from estimating LA for the 328 open growing trees. This sub-population of tree data contained 27 species of varying $\mathrm{DBH}$, from 6 to $105.9 \mathrm{~cm}$. SAS Enterprise software was used for all statistical analyses.

\subsection{Results \& Discussion}

Based on Eco inventory data describing canopy characteristics (e.g., crown dieback, missing crown), 270 of the total 328 park trees were determined to be in excellent health. Only 19 trees of those compared were assessed to be in poor, critical or dying condition, with the remaining 39 trees in fair or good condition. Results show a higher LA evaluation by Eco compared with Streets (Figure 4.1). For the 328 trees analyzed, the average tree LA value for the Eco analysis was $431.9 \mathrm{~m}^{2}$, and $212.6 \mathrm{~m}^{2}$ for the Streets analysis. On rare occasions, the LA estimates are higher for Streets. For example, a northern red oak in fair condition had estimated LA of $31.57 \mathrm{~m}^{2}$ for Eco and $60 \mathrm{~m}^{2}$ for Streets. LA data were assessed to have an approximate normal distribution and linear correlation analysis was used to determine similarity between modeled LA results. For the LA estimates produced by i-Tree Eco and Streets, for the open growing canopy trees 


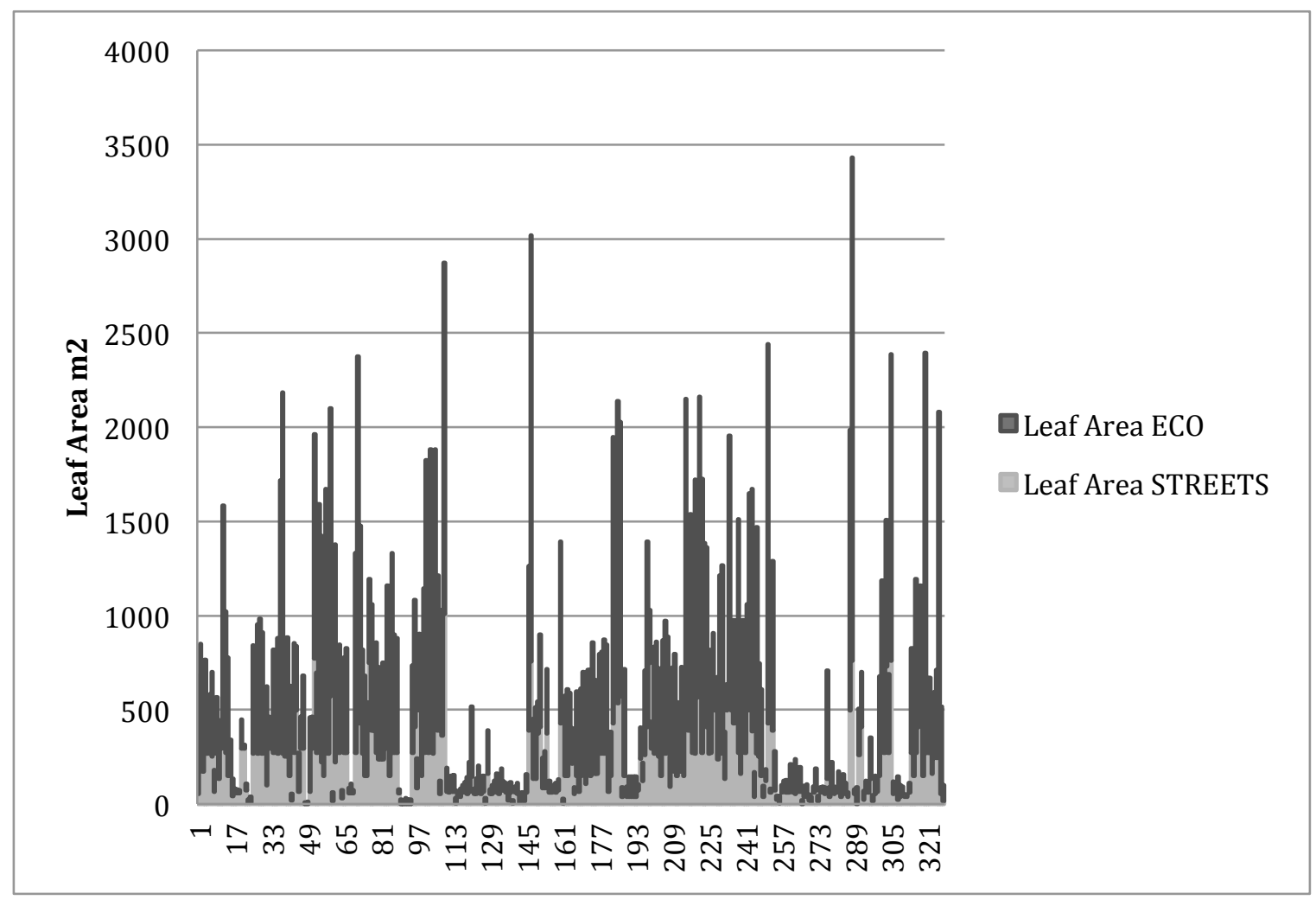

Figure 4.1: Bar Chart showing the difference in leaf area estimates generated by i-Tree Eco \& Streets 
$(n=328)$, there was a relatively strong positive correlation present $(r=0.72, p<0.001)$

(Figure 4.2). While results show a fairly strong correlation between the LA estimates arising from each of the models, the scatterplot also shows clear evidence of outliers on both sides of the line of best fit, which highlights some stark differences in the LA estimates produced by the two models. In a study conducted by Millward and Sabir (2010) these authors used hemispherical photography to estimate LA for individual trees in an urban park. Their results showed that STRATUM (now Streets) estimates of LA were higher than their empirically generated estimates. Because Streets, when applied to Toronto data, uses reference data from trees surveyed in Queens, NY (McPherson, 2010) and does not require input describing tree canopy condition (e.g., missing canopy and crown dieback), its output for tree inventories that (a) may be far from the reference city; and, (b) may have tree conditions that deviate from "average", should be approached with caution.

In Earlscourt Park, the majority of open canopy trees are in excellent condition. The Eco LA estimates are based on an inventory of detailed characteristics for each tree, including specific estimates of canopy presence. Research conducted by Welch (1994) found that urban park trees in Boston were in better overall health than street trees. Therefore, the variation in LA evident in the correlation analysis of Streets and Eco output for Earlscourt Parks may not be unexpected. Clearly, the canopy condition of a tree is critical to determining appropriate tree-specific LA estimates. Therefore, despite its ease of use (i.e., requiring minimal data collection per tree), findings of this research suggest that the Streets model may be too simplistic for accurately estimating LA and the 


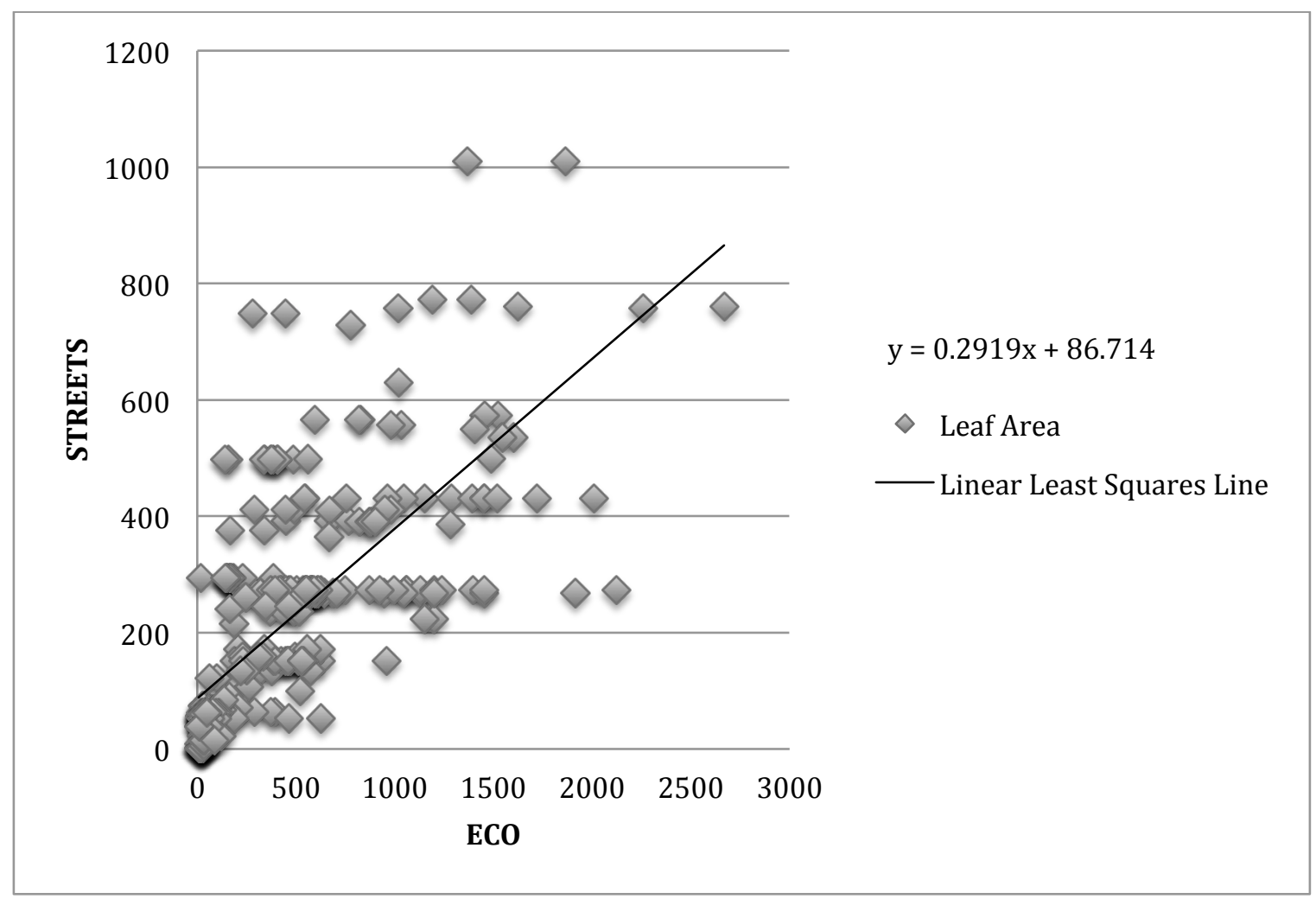

Figure 4.2: Scatterplot for leaf area $\left(\mathrm{m}^{2}\right)$ estimates for Eco and Streets $(r=0.72, p<0.001)$. 
subsequent delivery of ecological services. Overall, findings point toward two classes of model: (1) a "quick-and-dirty" assessment of the general benefits associated with a collection of urban trees (Streets); and, (2) a comprehensive assessment of tree-specific benefits that is not geographically or land-use dependent (Eco).

\subsection{Conclusion}

In circumstances where trees have higher than average canopy conditions (i.e., full crowns and little evidence of canopy dieback), or may be characterized by generally poor health (i.e., missing canopy resulting from storms, past maintenance, or vandalism), there is reasonable probability that leaf area calculations performed by Streets will not capture these important distinctions, which directly affect the accurate estimation of ecological services delivered by urban trees. Therefore, in instances where detailed ecological services analyses are required (especially on a per-tree basis), the lack of specific tree detail required by Streets limits its effectiveness. Where resources permit collection of more comprehensive tree-specific details, Eco is recommended for tree benefits estimation. Eco output is more accurate as it considers tree condition and it is not geographically or land-use dependent. 


\subsection{References}

City of Boston. (2013). Urban forestry. Retrieved August/10, 2013, from http://www.cityofboston.gov/parks/streettrees/

City of Toronto. (2013). Urban forestry. Retrieved July/23, 2013, from http://www.toronto.ca/trees/

i-Tree. (2012). What is i-tree? Retrieved June/15, 2013, from http://www.itreetools.org/index.php

Martin, N.A., Chappelka, A., Keever, G., Loewenstein, E. (2011). A 100\% Tree inventory using i-Tree Eco protocol: a case study at Auburn University, Alabama, U.S. Arboriculture \& urban forestry, 37 (5), 207-212.

McPherson, G. (2010). Selecting reference cities for i-tree streets. Arboriculture and Urban Forestry, 36(5), 230.

Millward, A. A., \& Pothier A. (2013). Institutional valuation of tree cover in a city centre: An urban forest management opportunity. Landscape and Urban Planning, 1(23).

Millward, A. A., \& Sabir, S. (2010). Structure of a forested urban park: Implications for strategic management. Journal of Environmental Management, 91(11), 2215-2224.

Millward, A. A., \& Sabir, S. (2011). Benefits of a forested urban park: What is the value of allan gardens to the city of toronto, canada? Landscape and Urban Planning, 100(3), 177-188.

Semenzato, P., Cattaneo, D., \& Dainese, M. (2011). Growth prediction for five tree species in an italian urban forest. Urban Forestry \& Urban Greening, 10(3), 169-176.

Welch, J. M. (1994). Street and park trees of boston: A comparison of urban forest structure. Landscape and Urban Planning, 29(2-3), 131-143. 


\section{Chapter 5}

\subsection{Data Collection Limitations}

One of the major challenges faced during data collection for this study was how to handle trees with $\mathrm{DBH}$ less than $6 \mathrm{~cm}$. As the park has a natural ravine on the southern and western sides, a lot of tree regeneration was observed to be occurring in this area. The decision to exclude young trees $(<6 \mathrm{~cm} \mathrm{DBH})$ was based on uncertainty concerning their survivability and the logistical challenges associated with collection of data on so many small trees. Younger (and smaller) trees growing in public parks are often subject to vandalism (Adler, 2012). They may also be more susceptible to extreme conditions such as flooding or drought (Boyce, 1938). Furthermore, Earlscourt Parks was found to have a fairly large population of the Elm-leaved Sumac (Rhus coriaria) trees. This plant is considered a shrub in some studies and a tree in others. In this study it was considered a shrub and excluded from the inventory database.

The dense tree canopy in the ravine area of the park presented a challenge during data collection as it made crown width measurement of younger trees difficult. To address this issue, the tree was shaken at its truck so as to recognize the correct edge of the crown. This shaking method was also used to identify the top of crowns for correct clinometer measurements. The boundaries of the park have slopes on the south, east and west sides, which complicated the use of the survey measuring wheel to measure the distance away from the tree, for accurate use of the clinometer. In such cases, a measuring tape was used to avoid errors in recording distance. Although the ravine conditions made this collection of data 
challenging, and excluding it from the inventory was considered, in the end it was determined that these data would be useful to future studies of the park.

\subsection{Model Uncertainties}

As with all predictive models, there are some uncertainties attached to analyses reported in this project. In terms of tree health, the i-Tree Forecast model does not consider major changes in the park that might harm the growth and health of the trees in future. For example, there are possibilities of future construction, which could lead to root zone damage and compromise tree growth and safety. Yet unknown diseases and pest infestations are also a possibility and were not considered in the forecasting of tree growth and mortality. Any of these possible scenarios could have an important influence on the growth of affected trees. Therefore, ensuring diversity in tree species and age structure is essential to buffering urban forests from future threats.

The i-Tree Forecast modeling approach used in this study relies on growing season length; however, alterations in precipitation patterns (i.e., varing amounts and timing of accumulation) will also affect the growth of trees. Storms that occur toward the end of a growing season may also be especially damaging to trees as lengthening growing seasons may make trees more vulnerable to storms. Trees with indeterminate growing conditions are vulnerable to late seasons storms as they might be in a growing stage during an extreme weather event (e.g., drought or freezing rain) (Boyce, 1938). In the present project, the potential impact on tree growth of future storms was not addressed. 
Although the primary purpose of the project was to create a forecasting methodology and estimate the future conditions of the major tree species in the study park, the results also highlight the role played by some less dominant tree species. For example, the less abundant London plane tree played an important role in contributing to the ecological benefits of the park. Therefore, while the study was selective in the tree species it presented results for, other less abundant tree species represent important contributors to the ecological benefits arising from Earlscourt Park trees.

\subsection{Project Significance}

This study is one of the first of its kind to integrate climate change storylines with urban tree growth estimates. With countless possibilities for the future climate conditions of the planet, it was important to identify several plausible climate change scenarios ranging from moderate to more extreme when undertaking the tree growth and mortality forecast. The use of IPCC storylines provided some consideration of the major global dynamics such as economy, population, technology and environmental awareness that could affect climate and ultimately the future of urban park trees. By embracing such storylines in the modeling, the study attempted to be holistic in its approach to uncovering possible future urban forest scenarios for Earlscourt Park.

\subsection{Future Research}

In this project, the structural growth and carbon storage of park trees was estimated for three separate climate change scenarios, varying tree mortality rates 
and a replanting scenario. However, no attempt was made to forecast the future of the park trees to ameliorate air pollution. Because a tree's potential to mitigate air pollution is heavily dependent on air pollution data at future points in time, a forecast of expected air pollution would also be required. This could include forecasts of concentrations of $\mathrm{O}_{3}, \mathrm{SO}_{2}, \mathrm{CO}, \mathrm{NO}_{2}$ and $\mathrm{PM} 2.5$. Future pollution levels could be predicted based on the IPCC climate change storylines. Changes to the global industrial sector such as the use of fossil fuel, global trade, and the introduction of innovative less resource intensive technologies could also be used, for example, to develop future air pollution scenarios. Similar to estimating future air pollution benefits of trees, storm water runoff mitigation predictions would require future estimates of precipitation timing, amount and rates of accumulation. Therefore, a next step in further refining i-Tree Forecast would be to include the ability to estimate these future ecological benefits.

The methods developed in this project open the door for further improvements to i-Tree Forecast as well as additional studies. The research was conducted in a city park, which has both managed trees and naturally growing ravine trees. The project has developed a methodological approach that could, for example, evaluate the difference in ecological benefits provided by managed park trees in comparison to naturally growing trees, where results are likely to vary for both structural and ecological benefits. The condition of a tree canopy is dependent on various factors that include exposure to light and competition for resources. While collecting data for this project, it was also observed that tree health was dependent on some less obvious factors. For example, it was clear that tree damage had been caused by construction and vandalism, and that many trees had 
sustained regular damage from grass trimmers and lawn cutting machinery; in some cases this led to degraded tree conditions among the managed trees.

The comparison of the structural condition of the two sub-communities of Earlscourt Park (i.e., trees growing in managed versus natural conditions) could also be an important future investigation. In addition to structural condition, the difference in the ecological services delivered by each could be an important line if inquiry. Tree benefits could be quantified on a species by species basis and also based on the amount of canopy. The hypothesis that a more natural urban forest could perform better than one subject to a traditional management approach could be explored.

As mentioned in the methodological section of Chapter Three, the mapping tools used in this research project can have application in the field of science and management. For example, development of an application that could integrate the i-Tree Forecast model with a GIS would take an important step forward concerning visualization of future park scenarios (i.e., tree growth and associated benefits). New vector layers describing tree growth under future climate, tree mortality and replanting scenarios could be created and easily shared with planners for inclusion in computer aided drawing (CAD) software. Such data would permit the future scenario-based visualization of alterations to tree height, canopy cover and light exposure. Furthermore, the attributes associated with each of these vector layers could encompass the non-visual ecological services. 


\subsection{References}

Boyce, J. (1938). Forest pathology. New York \& London: McGraw-Hill.

Hirabayashi, S., Kroll, C., \& Nowak, D. (2012). i-tree eco dry deposition model descriptions. (Model Description No. 1.1). Syracust, NY: The Davey Tree Expert Company.

Semenzato, P., Cattaneo, D., \& Dainese, M. (2011). Growth prediction for five tree species in an italian urban forest. Urban Forestry \& Urban Greening, 10(3), 169-176. 


\section{Appendix A: Tree Inventory}

\begin{tabular}{|c|c|c|c|c|c|c|c|c|c|c|c|c|c|c|c|c|c|c|}
\hline TreeID & Date & $\mathrm{x}$ & $\mathrm{Y}$ & PhotoID & Species & DBH1 & DBH2 & DBH3 & DBH4 & TOTHT & Live Top & Crown Base & Crown Width NS & Crown Width EW & $\begin{array}{l}\text { Percent Crown } \\
\text { Missing }\end{array}$ & & Crown Dieback & CLE \\
\hline 1 & 15-Jun-12 & -79.45452825 & 43.67518551 & 125 & ACSA1 & $\begin{array}{r}2.7559 \\
07 \\
51\end{array}$ & & & & 16.4042 & 11.48294 & 4.92126 & 9.843 & 8.2025 & & 0 & 8 & 5 \\
\hline 2 & 15-Jun-12 & -79.45448032 & 43.67519542 & 127 & ACPL & $\begin{array}{r}12.519 \\
6918 \\
15.669\end{array}$ & & & & 30.183728 & 19.68504 & 10.498688 & 31.1695 & 30.8414 & & 0 & 48 & 5 \\
\hline 3 & 15-Jun-12 & -79.45435491 & 43.67517026 & 129 & ACPL & $\begin{array}{r}2998 \\
20.196\end{array}$ & & & & 33.956694 & 24.114174 & 9.84252 & 36.7472 & 34.4505 & & 0 & 68 & 4 \\
\hline 4 & 15-Jun-12 & -79.45431566 & 43.67499905 & 132 & TICO & $\begin{array}{r}8613 \\
18.070\end{array}$ & & & & 37.893702 & 26.082678 & 11.811024 & 44.2935 & 46.5902 & & 0 & 0 & 4 \\
\hline 5 & 15-Jun-12 & -79.45436908 & 43.67486992 & 134 & ACPL & $\begin{array}{r}8759 \\
22.125\end{array}$ & & & & 43.307088 & 32.8084 & 10.498688 & 41.9968 & 43.3092 & & 0 & 3 & 4 \\
\hline 6 & 15-Jun-12 & -79.45429098 & 43.67523978 & 136 & тісо & $\begin{array}{r}9962 \\
13.543\end{array}$ & & & & 45.275592 & 34.776904 & 10.498688 & 47.2464 & 39.372 & & 0 & 0 & 4 \\
\hline 7 & 15-Jun-12 & -79.45429145 & 43.67531603 & 138 & ACPL & $\begin{array}{r}3144 \\
19.251\end{array}$ & & & & 28.543308 & 20.669292 & 7.874016 & 29.529 & 29.529 & & 0 & 3 & 5 \\
\hline 8 & 15-Jun-12 & -79.45413668 & 43.67535441 & 140 & TICO & $\begin{array}{r}9789 \\
20.039\end{array}$ & & & & 32.972442 & 25.098426 & 7.874016 & 41.0125 & 37.0753 & & 0 & 0 & 5 \\
\hline 9 & 15-Jun-12 & -79.45396863 & 43.67537554 & 142 & TICO & $\begin{array}{r}3809 \\
19.685\end{array}$ & & & & 37.401576 & 27.559056 & 9.84252 & 59.7142 & 43.6373 & & 0 & 0 & 4 \\
\hline 10 & 15-Jun-12 & -79.4537883 & 43.67541181 & 144 & ACPL & $\begin{array}{r}05 \\
15.314\end{array}$ & & & & 32.480316 & 23.622048 & 8.858268 & 39.372 & 37.4034 & & 0 & 0 & 4 \\
\hline 11 & 15-Jun-12 & -79.45362658 & 43.67545056 & 146 & ACPL & $\begin{array}{r}9689 \\
13.307\end{array}$ & & & & 37.401576 & 28.051182 & 9.350394 & 30.8414 & 29.8571 & & 0 & 23 & 4 \\
\hline 12 & 15-Jun-12 & -79.45348402 & 43.67549485 & 148 & ACPL & $\begin{array}{r}0938 \\
12.165\end{array}$ & & & & 31.496064 & 23.622048 & 7.874016 & 30.8414 & 27.8885 & & 0 & 3 & 5 \\
\hline 13 & 15-Jun-12 & -79.45334907 & 43.67552645 & 150 & TICO & $\begin{array}{r}3609 \\
10.944\end{array}$ & & & & 24.934384 & 17.388452 & 7.545932 & 23.6232 & 22.967 & & 18 & 0 & 5 \\
\hline 14 & 15-Jun-12 & -79.45422195 & 43.67519011 & 152 & ACPL & $\begin{array}{r}8878 \\
13.700\end{array}$ & & & & 23.293964 & 18.700788 & 4.593176 & 28.8728 & 20.0141 & & 0 & 0 & 4 \\
\hline 15 & 15-Jun-12 & -79.4541435 & 43.6750763 & 155 & ACPL & $\begin{array}{r}7948 \\
18.110\end{array}$ & & & & 19.028872 & 11.48294 & 7.545932 & 29.529 & 25.9199 & & 0 & 0 & 4 \\
\hline 16 & 15-Jun-12 & -79.45413024 & 43.67526967 & 158 & TICO & $\begin{array}{r}246 \\
19133\end{array}$ & & & & 41.994752 & 28.871392 & 13.12336 & 28.2166 & 27.5604 & & 0 & 0 & 5 \\
\hline 17 & 15-Jun-12 & -79.45402161 & 43.67530003 & 161 & тісо & $\begin{array}{r}8686 \\
19.133\end{array}$ & & & & 24.114174 & 16.732284 & 7.38189 & 25.2637 & 21.6546 & & 0 & 0 & 5 \\
\hline 19 & 15-Jun-12 & -79.4534559 & 43.67538872 & 167 & TICO & $\begin{array}{r}8686 \\
17874\end{array}$ & & & & 24.6063 & 16.732284 & 7.874016 & 27.8885 & 24.9356 & & 0 & 0 & 5 \\
\hline 20 & 15-Jun-12 & -79.45369074 & 43.67518802 & 170 & FRPE & $\begin{array}{r}0254 \\
22.047\end{array}$ & 12.637 & 16.771 & & 39.37008 & 28.543308 & 10.826772 & 40.6844 & 34.4505 & & 0 & 0 & 5 \\
\hline 21 & 15-Jun-12 & -79.45358045 & 43.67514438 & 173 & TICO & $\begin{array}{r}256 \\
5.2362\end{array}$ & 8021 & 6626 & & 27.06693 & 20.177166 & 6.889764 & 23.9513 & 26.248 & & 0 & 3 & 5 \\
\hline 22 & 15-Jun-12 & -79.4535767 & 43.67502287 & 176 & ACSA1 & $\begin{array}{r}233 \\
12.007\end{array}$ & & & & 30.019686 & 22.14567 & 7.874016 & 16.405 & 14.7645 & & 0 & 0 & 5 \\
\hline 23 & 15-Jun-12 & -79.45344122 & 43.67507437 & 179 & ACSA1 & $\begin{array}{r}8805 \\
11.141\end{array}$ & & & & 37.893702 & 23.622048 & 14.271654 & 26.248 & 27.2323 & & 0 & 0 & 5 \\
\hline 24 & 15-Jun-12 & -79.45350633 & 43.67498492 & 182 & QURU & $\begin{array}{r}7383 \\
24.055\end{array}$ & & & & 25.590552 & 18.700788 & 6.889764 & 27.8885 & 29.8571 & & 0 & 0 & 5 \\
\hline 25 & 15-Jun-12 & -79.45350527 & 43.67488771 & 185 & ACPL & $\begin{array}{r}1311 \\
21.299\end{array}$ & & & & 46.587928 & 28.871392 & 17.716536 & 48.5588 & 48.2307 & & 8 & 13 & 4 \\
\hline 26 & 15-Jun-12 & -79.45367097 & 43.67491489 & 188 & ACPL & $\begin{array}{r}2241 \\
17.716 \\
545\end{array}$ & & & & 37.893702 & 25.098426 & 12.795276 & 39.7001 & 46.5902 & & 23 & 0 & 3 \\
\hline
\end{tabular}




\begin{tabular}{|c|c|c|c|c|c|c|c|c|c|c|c|c|c|}
\hline 29 & 15-Jun-12 & -79.45286485 & 43.67561461 & 197 & ACPL & $\begin{array}{r}21.811 \\
0354 \\
22.795\end{array}$ & 42.65092 & 28.215224 & 14.435696 & 32.81 & 40.6844 & 0 & 23 \\
\hline 30 & 15-Jun-12 & -79.45270784 & 43.67565489 & 200 & ACPL & $\begin{array}{r}2879 \\
11.220\end{array}$ & 47.900264 & 30.839896 & 17.060368 & 47.5745 & 55.1208 & 0 & 8 \\
\hline 31 & 15-Jun-12 & -79.45256009 & 43.67568558 & 203 & ACPL & $\begin{array}{r}4785 \\
12.913\end{array}$ & 31.003938 & 18.208662 & 12.795276 & 27.8885 & 28.8728 & 0 & 28 \\
\hline 32 & 15-Jun-12 & -79.45240788 & 43.67571449 & 206 & GLTR & $\begin{array}{r}3928 \\
17.716\end{array}$ & 34.44882 & 22.637796 & 11.811024 & 31.1695 & 32.81 & 0 & 0 \\
\hline 36 & 15-Jun-12 & -79.4541553 & 43.6745958 & 218 & PIST & $\begin{array}{r}545 \\
15.826\end{array}$ & 38.877954 & 31.003938 & 7.874016 & 22.3108 & 28.2166 & 0 & 0 \\
\hline 37 & 15-Jun-12 & -79.45409984 & 43.6745871 & 221 & PIST & $\begin{array}{r}7802 \\
13.464\end{array}$ & 40.846458 & 29.035434 & 11.811024 & 22.3108 & 22.3108 & 0 & 0 \\
\hline 38 & 15-Jun-12 & -79.45414391 & 43.67457709 & 224 & PIST & $\begin{array}{r}5742 \\
15.905\end{array}$ & 42.322836 & 25.590552 & 16.732284 & 14.7645 & 17.7174 & 0 & 0 \\
\hline 39 & 15-Jun-12 & -79.4541909 & 43.67455984 & 227 & PIST & $\begin{array}{r}5204 \\
15.354\end{array}$ & 31.98819 & 21.653544 & 10.334646 & 21.3265 & 20.3422 & 0 & 0 \\
\hline 40 & 15-Jun-12 & -79.45417401 & 43.67450662 & 231 & PIST & $\begin{array}{r}339 \\
12.204\end{array}$ & 30.019686 & 23.129922 & 6.889764 & 15.7488 & 21.6546 & 0 & 13 \\
\hline 41 & 15-Jun-12 & -79.45411633 & 43.67451379 & 234 & PIST & $\begin{array}{r}731 \\
13.385\end{array}$ & 31.496064 & 19.192914 & 12.30315 & 14.7645 & 17.3893 & 0 & 0 \\
\hline 42 & 15-Jun-12 & -79.45407257 & 43.67451187 & 237 & PIST & $\begin{array}{r}834 \\
9.3700\end{array}$ & 34.940946 & 23.700788 & 11.240158 & 14.7645 & 20.9984 & 0 & 18 \\
\hline 43 & 15-Jun-12 & -79.4541481 & 43.67448507 & 240 & PIST & $\begin{array}{r}838 \\
9.0944\end{array}$ & 25.590552 & 15.091864 & 10.498688 & 16.405 & 14.4364 & 0 & 3 \\
\hline 44 & 15-Jun-12 & -79.45411787 & 43.6744893 & 243 & PIST & $\begin{array}{r}931 \\
34.881\end{array}$ & 24.6063 & 14.107612 & 10.498688 & 15.0926 & 20.3422 & 0 & 0 \\
\hline 45 & 15-Jun-12 & -79.45411315 & 43.67446009 & 246 & FRPE & $\begin{array}{r}9086 \\
22.086\end{array}$ & 53.805776 & 30.839896 & 22.96588 & 75.463 & 60.6985 & 0 & 18 \\
\hline 46 & 15-Jun-12 & -79.45391909 & 43.6746244 & 249 & ACSA1 & $\begin{array}{r}6261 \\
26.377\end{array}$ & 38.385828 & 28.051182 & 10.334646 & 54.1365 & 48.8869 & 0 & 3 \\
\hline 47 & 15-Jun-12 & -79.45383085 & 43.67458809 & 252 & ACPL & $\begin{array}{r}967 \\
25.629\end{array}$ & 49.868768 & 39.37008 & 10.498688 & 58.4018 & 61.3547 & 0 & 0 \\
\hline 48 & 15-Jun-12 & -79.45354184 & 43.67462923 & 255 & ACPL & $\begin{array}{r}9351 \\
31.220\end{array}$ & 53.805776 & 42.65092 & 11.154856 & 55.4489 & 41.0125 & 0 & 0 \\
\hline 49 & 15-Jun-12 & -79.45337072 & 43.67465341 & 258 & ACSA1 & $\begin{array}{r}4893 \\
25275\end{array}$ & 45.93176 & 37.401576 & 8.530184 & 62.6671 & 61.6828 & 0 & 0 \\
\hline 50 & 15-Jun-12 & -79.45367625 & 43.67436472 & 261 & PLAC1 & $\begin{array}{r}6042 \\
22.795\end{array}$ & 66.929136 & 52.49344 & 14.435696 & 59.058 & 49.215 & 0 & 0 \\
\hline 51 & 15-Jun-12 & -79.45379799 & 43.67430379 & 263 & ACPL & $\begin{array}{r}2879 \\
26.574\end{array}$ & 49.2126 & 40.682416 & 8.530184 & 55.777 & 65.62 & 0 & 0 \\
\hline 52 & 15-Jun-12 & -79.45365486 & 43.6741805 & 265 & ACSA1 & $\begin{array}{r}8175 \\
19.685\end{array}$ & 51.837272 & 45.275592 & 6.56168 & 65.62 & 68.901 & 0 & 0 \\
\hline 53 & 15-Jun-12 & -79.45343051 & 43.67411678 & 267 & ACPL & $\begin{array}{r}05 \\
3.5433\end{array}$ & 50.524936 & 41.338584 & 9.186352 & 39.372 & 36.091 & 0 & 0 \\
\hline 55 & 15-Jun-12 & -79.45385808 & 43.67420221 & 271 & PIRE & $\begin{array}{r}09 \\
4.3307\end{array}$ & 14.76378 & 12.30315 & 2.46063 & 7.8744 & 7.8744 & 0 & 0 \\
\hline 56 & 15-Jun-12 & -79.45383595 & 43.67419906 & 274 & PIST & $\begin{array}{r}11 \\
4.1338\end{array}$ & 15.58399 & 13.779528 & 1.804462 & 12.7959 & 12.7959 & 0 & 0 \\
\hline 57 & 15-Jun-12 & -79.45386187 & 43.6742582 & 277 & PIST & $\begin{array}{r}605 \\
3.1496\end{array}$ & 11.646982 & 11.154856 & 0.492126 & 10.8273 & 10.8273 & 0 & 0 \\
\hline 58 & 15-Jun-12 & -79.45384139 & 43.6742418 & 279 & PIST & $\begin{array}{r}08 \\
3.5433\end{array}$ & 11.646982 & 11.154856 & 0.492126 & 8.2025 & 9.1868 & 0 & 0 \\
\hline 59 & 15-Jun-12 & -79.45387812 & 43.67423566 & 281 & PIST & $\begin{array}{r}09 \\
16.535\end{array}$ & 16.4042 & 14.271654 & 2.132546 & 11.1554 & 11.1554 & 0 & 0 \\
\hline 62 & 15-Jun-12 & -79.45193 & 43.67582962 & 285 & ACPL & $\begin{array}{r}442 \\
12.007\end{array}$ & 30.183728 & 18.372704 & 11.811024 & 41.6687 & 44.2935 & 0 & 0 \\
\hline $\begin{array}{l}63 \\
64\end{array}$ & $\begin{array}{l}15 \text {-Jun-12 } \\
15 \text {-Jun-12 }\end{array}$ & $\begin{array}{l}-79.45181029 \\
-79.45168016\end{array}$ & $\begin{array}{l}43.67586213 \\
43.67589356\end{array}$ & $\begin{array}{l}287 \\
289\end{array}$ & ACPL & $\begin{array}{r}8805 \\
16.535 \\
442\end{array}$ & $\begin{array}{l}21.653544 \\
33.956694\end{array}$ & $\begin{array}{l}11.811024 \\
26.082678\end{array}$ & $\begin{array}{r}9.84252 \\
7.874016\end{array}$ & $\begin{array}{l}23.9513 \\
35.1067\end{array}$ & $\begin{array}{l}21.3265 \\
33.7943\end{array}$ & 0 & 0 \\
\hline
\end{tabular}




\begin{tabular}{|c|c|c|c|c|c|c|c|c|c|c|c|c|c|}
\hline 65 & 15-Jun-12 & -79.45172742 & 43.67583352 & 291 & PIPU & $\begin{array}{r}4.7244 \\
12 \\
4.7244\end{array}$ & 17.388452 & 13.545912 & 3.84254 & 10.4992 & 9.843 & 0 & 0 \\
\hline 66 & 15-Jun-12 & -79.45165644 & 43.67585057 & 292 & PIPU & $\begin{array}{r}12 \\
12 \\
4.7244\end{array}$ & 21.32546 & 18.04462 & 3.28084 & 13.4521 & 13.124 & 0 & 0 \\
\hline 67 & 15-Jun-12 & -79.45159204 & 43.67586582 & 293 & PSME & $\begin{array}{r}12 \\
12 \\
4.7244\end{array}$ & 21.32546 & 18.04462 & 3.28084 & 13.4521 & 13.124 & 0 & 0 \\
\hline 68 & 17-Jun-12 & -79.45153824 & 43.67587552 & 294 & PSME & $\begin{array}{r}12 \\
12 \\
4.7244\end{array}$ & 21.32546 & 18.04462 & 3.28084 & 13.4521 & 13.124 & 0 & 0 \\
\hline 69 & 17-Jun-12 & -79.45149618 & 43.67588537 & 295 & PSME & $\begin{array}{r}12 \\
12 \\
8.0708\end{array}$ & 21.32546 & 18.04462 & 3.28084 & 13.4521 & 13.124 & 0 & 0 \\
\hline 70 & 17-Jun-12 & -79.45159526 & 43.67589335 & 298 & $\mathrm{AM}$ & $\begin{array}{r}705 \\
12.165\end{array}$ & 29.035434 & 20.669292 & 8.366142 & 18.0455 & 17.0612 & 0 & 0 \\
\hline 71 & 17-Jun-12 & -79.45144623 & 43.67594822 & 300 & $\mathrm{ACPL}$ & $\begin{array}{r}3609 \\
4.1338\end{array}$ & 31.496064 & 23.622048 & 7.874016 & 31.8257 & 27.5604 & 0 & 38 \\
\hline 72 & 17-Jun-12 & -79.45129398 & 43.6759765 & 302 & GLTR & $\begin{array}{r}605 \\
3.7007\end{array}$ & 19.68504 & 11.811024 & 7.874016 & 12.7959 & 17.3893 & 0 & 0 \\
\hline 73 & 17-Jun-12 & -79.4512467 & 43.67598629 & 304 & GLTR & $\begin{array}{r}894 \\
35433\end{array}$ & 18.700788 & 11.318898 & 7.38189 & 12.4678 & 15.4207 & 0 & 0 \\
\hline 74 & 17-Jun-12 & -79.45119013 & 43.67600164 & 306 & GLTR & $\begin{array}{r}09 \\
12.874\end{array}$ & 18.700788 & 11.811024 & 6.889764 & 13.124 & 12.1397 & 0 & 0 \\
\hline 75 & 17-Jun-12 & -79.45121591 & 43.67586261 & 308 & GLTR & $\begin{array}{r}0227 \\
2.7559\end{array}$ & 41.338584 & 31.98819 & 9.350394 & 45.2778 & 44.6216 & 0 & 0 \\
\hline 76 & 17-Jun-12 & -79.45111482 & 43.67567921 & 310 & GLTR & $\begin{array}{r}07 \\
3.1496\end{array}$ & 18.700788 & 13.451444 & 5.249344 & 11.4835 & 14.7645 & 0 & 0 \\
\hline 77 & 17-Jun-12 & -79.451078 & 43.67563794 & 313 & ACRU & $\begin{array}{r}.140 \\
08 \\
3.1496\end{array}$ & 17.060368 & 10.826772 & 6.233596 & 11.1554 & 9.843 & 0 & 0 \\
\hline 78 & 17-Jun-12 & -79.45104263 & 43.675591 & 315 & ACRU & $\begin{array}{r}08 \\
2.6771\end{array}$ & 15.419948 & 10.498688 & 4.92126 & 11.8116 & 10.4992 & 0 & 0 \\
\hline 79 & 17-Jun-12 & -79.45088237 & 43.67552436 & 317 & QURU & $\begin{array}{r}668 \\
14.921\end{array}$ & 13.779528 & 8.2021 & 5.577428 & 6.8901 & 7.8744 & 0 & 0 \\
\hline 80 & 17-Jun-12 & -79.45091716 & 43.67544139 & 319 & QUMA1 & $\begin{array}{r}2679 \\
9,0944\end{array}$ & 51.181104 & 40.682416 & 10.498688 & 19.0298 & 21.9827 & 0 & 0 \\
\hline 81 & 17-Jun-12 & -79.45089732 & 43.67540036 & 321 & QUMA1 & $\begin{array}{r}931 \\
2.9133\end{array}$ & 36.08924 & 26.902888 & 9.186352 & 13.7802 & 14.4364 & 0 & 0 \\
\hline 82 & 17-Jun-12 & -79.45079534 & 43.67530227 & 323 & QURU & $\begin{array}{r}874 \\
29.606\end{array}$ & 19.356956 & 14.107612 & 5.249344 & 7.8744 & 11.4835 & 0 & 0 \\
\hline 83 & 17-Jun-12 & -79.45073915 & 43.67515075 & 325 & TICO & $\begin{array}{r}3152 \\
15.039\end{array}$ & 38.713912 & 28.871392 & 9.84252 & 32.1538 & 33.7943 & 0 & 0 \\
\hline 84 & 17-Jun-12 & -79.45069724 & 43.67505348 & 327 & GLTR & $\begin{array}{r}3782 \\
21.850\end{array}$ & 42.65092 & 30.183728 & 12.467192 & 34.1224 & 36.091 & 0 & 0 \\
\hline 85 & 17-Jun-12 & -79.4506569 & 43.67494579 & 329 & TICO & $\begin{array}{r}4055 \\
22.362\end{array}$ & 50.524936 & 38.713912 & 11.811024 & 29.529 & 31.8257 & 0 & 0 \\
\hline 86 & 17-Jun-12 & -79.45062275 & 43.67485147 & 331 & GLTR & $\begin{array}{r}2168 \\
22.755\end{array}$ & 57.4147 & 45.11155 & 12.30315 & 55.777 & 62.339 & 0 & 0 \\
\hline 87 & 17-Jun-12 & -79.45056977 & 43.67472749 & 333 & TICO & $\begin{array}{r}9178 \\
17.913\end{array}$ & 45.93176 & 35.26903 & 10.66273 & 36.091 & 36.091 & 0 & 0 \\
\hline 88 & 17-Jun-12 & -79.45052959 & 43.67461412 & 335 & GLTR & $\begin{array}{r}3955 \\
14.645\end{array}$ & 40.19029 & 29.52756 & 10.66273 & 49.215 & 45.934 & 0 & 0 \\
\hline 89 & 17-Jun-12 & -79.45094542 & 43.67449556 & 337 & ACPL & $\begin{array}{r}6772 \\
13.464\end{array}$ & 36.08924 & 26.24672 & 9.84252 & 29.529 & 32.81 & 0 & 0 \\
\hline 90 & 17-Jun-12 & -79.4509026 & 43.67443335 & 339 & GLTR & $\begin{array}{r}5742 \\
12.401\end{array}$ & 33.464568 & 22.309712 & 11.154856 & 44.2935 & 42.653 & 0 & 0 \\
\hline 91 & 17-Jun-12 & -79.45118831 & 43.67444765 & 341 & GLTR & $\begin{array}{r}5815 \\
16.929\end{array}$ & 24.278216 & 19.68504 & 4.593176 & 32.81 & 42.653 & 0 & 0 \\
\hline 92 & 17-Jun-12 & -79.45120639 & 43.67435403 & 343 & ACRU & $\begin{array}{r}143 \\
22.440\end{array}$ & 38.713912 & 30.839896 & 7.874016 & 32.81 & 32.81 & 0 & 0 \\
\hline 93 & 17-Jun-12 & -79.45135851 & 43.67438169 & 345 & ACPL & $\begin{array}{r}957 \\
23.622\end{array}$ & 45.93176 & 37.401576 & 8.530184 & 42.653 & 42.653 & 0 & 0 \\
\hline
\end{tabular}




\begin{tabular}{|c|c|c|c|c|c|c|c|c|c|c|c|c|c|}
\hline 95 & 17-Jun-12 & -79.45095897 & 43.67422268 & 350 & GLTR & $\begin{array}{r}24.803 \\
163\end{array}$ & 38.713912 & 32.8084 & 5.905512 & 39.372 & 55.777 & 0 & 0 \\
\hline 96 & 17-Jun-12 & -79.45102759 & 43.67414492 & 352 & GLTR & $\begin{array}{r}16.141 \\
741 \\
22.440\end{array}$ & 44.619424 & 36.745408 & 7.874016 & 45.934 & 45.934 & 0 & 0 \\
\hline 97 & 17-Jun-12 & -79.45049484 & 43.67449229 & 354 & TICO & $\begin{array}{r}957 \\
21.259\end{array}$ & 32.152232 & 22.309712 & 9.84252 & 42.653 & 42.653 & 0 & 0 \\
\hline 98 & 17-Jun-12 & -79.45046045 & 43.67440744 & 357 & TICO & $\begin{array}{r}854 \\
7.4803\end{array}$ & 43.307088 & 30.183728 & 13.12336 & 39.372 & 39.372 & 0 & 0 \\
\hline 99 & 17-Jun-12 & -79.45044102 & 43.67435029 & 359 & ACRU & $\begin{array}{r}19 \\
13.385\end{array}$ & 25.9842528 & 20.0787408 & 5.905512 & 19.686 & 24.6075 & 0 & 0 \\
\hline 100 & 17-Jun-12 & -79.45041646 & 43.67428928 & 361 & FRPE & $\begin{array}{r}834 \\
17.322\end{array}$ & 41.994752 & 33.464568 & 8.530184 & 32.81 & 42.653 & 0 & 0 \\
\hline 101 & 17-Jun-12 & -79.45038838 & 43.67421305 & 363 & ACPL & $\begin{array}{r}844 \\
19.685\end{array}$ & 41.994752 & 32.8084 & 9.186352 & 42.653 & 41.0125 & 0 & 0 \\
\hline 102 & 17-Jun-12 & -79.4503617 & 43.67413305 & 365 & GLTR & $\begin{array}{r}05 \\
12.204\end{array}$ & 49.2126 & 40.682416 & 8.530184 & 52.496 & 50.8555 & 0 & 0 \\
\hline 103 & 17-Jun-12 & -79.45032702 & 43.67405957 & 367 & ACPL & $\begin{array}{r}731 \\
12.204\end{array}$ & 34.776904 & 26.902888 & 7.874016 & 22.967 & 24.6075 & 0 & 0 \\
\hline 104 & 17-Jun-12 & -79.45148771 & 43.67438629 & 369 & GLTR & $\begin{array}{r}731 \\
21.653\end{array}$ & 39.37008 & 25.590552 & 13.779528 & 36.091 & 42.653 & 0 & 0 \\
\hline 105 & 17-Jun-12 & -79.45157676 & 43.67432681 & 371 & тісо & $\begin{array}{r}1.053 \\
555 \\
27.559\end{array}$ & 49.2126 & 34.120736 & 15.091864 & 27.8885 & 32.81 & 0 & 0 \\
\hline 106 & 17-Jun-12 & -79.45175716 & 43.67432167 & 373 & ACPL & $\begin{array}{r}07 \\
20.078\end{array}$ & 50.524936 & 43.963256 & 6.56168 & 59.058 & 45.934 & 0 & 0 \\
\hline 107 & 17-Jun-12 & -79.45186628 & 43.67424351 & 375 & TICO & $\begin{array}{r}751 \\
32.677\end{array}$ & 51.181104 & 42.65092 & 8.530184 & 36.091 & 36.091 & 0 & 0 \\
\hline 108 & 17-Jun-12 & -79.45186103 & 43.67414294 & 377 & TICO & $\begin{array}{r}183 \\
18.503\end{array}$ & 52.49344 & 44.619424 & 7.874016 & 59.058 & 75.463 & 0 & 0 \\
\hline 109 & 17-Jun-12 & -79.45207388 & 43.67424727 & 379 & ACPL & $\begin{array}{r}947 \\
19.291\end{array}$ & 42.65092 & 32.152232 & 10.498688 & 39.372 & 36.091 & 0 & 0 \\
\hline 110 & 17-Jun-12 & -79.45215686 & 43.6741697 & 381 & ACPL & $\begin{array}{r}349 \\
11.023\end{array}$ & 50.524936 & 42.65092 & 7.874016 & 42.653 & 49.215 & 0 & 0 \\
\hline 111 & 17-Jun-12 & -79.45213631 & 43.67512133 & 384 & TICO & $\begin{array}{r}628 \\
16.929\end{array}$ & 23.622048 & 15.091864 & 8.530184 & 19.686 & 19.686 & 0 & 0 \\
\hline 112 & 17-Jun-12 & -79.45218517 & 43.67520258 & 386 & FRPE & $\begin{array}{r}143 \\
22.047\end{array}$ & 40.682416 & 26.24672 & 14.435696 & 49.215 & 42.653 & 0 & 0 \\
\hline 113 & 17-Jun-12 & -79.45325853 & 43.67455722 & 390 & ACPL & $\begin{array}{r}256 \\
19.685\end{array}$ & 45.93176 & 37.401576 & 8.530184 & 42.653 & 24.2794 & 33 & 0 \\
\hline 114 & 17-Jun-12 & -79.45314127 & 43.67444376 & 392 & ACPL & $\begin{array}{r}05 \\
14.566\end{array}$ & 40.026248 & 29.52756 & 10.498688 & 32.81 & 36.091 & 28 & 28 \\
\hline 115 & 17-Jun-12 & -79.4504038 & 43.67401984 & 395 & TICO & $\begin{array}{r}937 \\
20.866\end{array}$ & 47.900264 & 39.37008 & 8.530184 & 36.091 & 32.81 & 0 & 0 \\
\hline 116 & 17-Jun-12 & -79.45050685 & 43.67397478 & 397 & GLTR & $\begin{array}{r}153 \\
16.141\end{array}$ & 47.244096 & 40.026248 & 7.217848 & 59.058 & 52.496 & 0 & 0 \\
\hline 117 & 17-Jun-12 & -79.45029236 & 43.67398515 & 399 & ACPL & $\begin{array}{r}741 \\
13.385\end{array}$ & 45.93176 & 36.08924 & 9.84252 & 21.3265 & 21.3265 & 0 & 0 \\
\hline 118 & 17-Jun-12 & -79.45025804 & 43.67389746 & 401 & ACPL & $\begin{array}{r}834 \\
16.535\end{array}$ & 36.08924 & 28.871392 & 7.217848 & 22.967 & 22.967 & 0 & 0 \\
\hline 119 & 17-Jun-12 & -79.45030484 & 43.67385542 & 403 & TICO & $\begin{array}{r}442 \\
14.566\end{array}$ & 50.524936 & 43.307088 & 7.217848 & 22.967 & 22.967 & 0 & 0 \\
\hline 120 & 17-Jun-12 & -79.45051644 & 43.6738052 & 405 & TICO & $\begin{array}{r}937 \\
16.535\end{array}$ & 41.994752 & 35.433072 & 6.56168 & 26.248 & 24.6075 & 0 & 0 \\
\hline 121 & 23-Jun-12 & -79.45023016 & 43.67381364 & 407 & ACPL & $\begin{array}{r}442 \\
15.354\end{array}$ & 45.275592 & 39.37008 & 5.905512 & 26.248 & 26.248 & 0 & 0 \\
\hline 122 & 23-Jun-12 & -79.45018091 & 43.67374755 & 409 & ACPL & $\begin{array}{r}339 \\
17.322\end{array}$ & 42.65092 & 32.8084 & 9.84252 & 22.967 & 29.529 & 0 & 0 \\
\hline 123 & 23-Jun-12 & -79.4501624 & 43.67370559 & 411 & ACPL & $\begin{array}{r}844 \\
12.598\end{array}$ & 50.196852 & 35.433072 & 14.76378 & 32.81 & 37.7315 & 0 & 0 \\
\hline 124 & 23-Jun-12 & -79.45013765 & 43.67365216 & 413 & FRPE & 432 & 50.524936 & 39.37008 & 11.154856 & 42.653 & 32.81 & 0 & 3 \\
\hline
\end{tabular}




\begin{tabular}{|c|c|c|c|c|c|c|c|c|c|c|c|c|c|}
\hline 125 & 23-Jun-12 & -79.450118 & 43.67360354 & 416 & ACPL & $\begin{array}{r}12.598 \\
432 \\
13.385\end{array}$ & 40.682416 & 26.24672 & 14.435696 & 27.8885 & 29.529 & 23 & 0 \\
\hline 126 & 23-Jun-12 & -79.45009209 & 43.6735444 & 418 & FRPE & $\begin{array}{r}834 \\
34.251\end{array}$ & 53.805776 & 39.37008 & 14.435696 & 36.091 & 36.091 & 0 & 38 \\
\hline 128 & 23-Jun-12 & -79.45003078 & 43.67338903 & 422 & QUAL & $\begin{array}{r}987 \\
29.921\end{array}$ & 85.30184 & 62.33596 & 22.96588 & 59.058 & 68.901 & 0 & 0 \\
\hline 129 & 23-Jun-12 & -79.45025123 & 43.67345175 & 425 & ACPL & $\begin{array}{r}276 \\
4.3307\end{array}$ & 55.77428 & 45.93176 & 9.84252 & 62.339 & 59.058 & 0 & 0 \\
\hline 130 & 23-Jun-12 & -79.45041356 & 43.67353928 & 427 & MA2 & $\begin{array}{r}11 \\
20.472\end{array}$ & 15.419948 & 12.467192 & 2.952756 & 10.8273 & 9.843 & 0 & 0 \\
\hline 131 & 23-Jun-12 & -79.45058803 & 43.67351036 & 429 & ACPL & $\begin{array}{r}452 \\
18.503\end{array}$ & 45.93176 & 32.8084 & 13.12336 & 49.215 & 32.81 & 0 & 0 \\
\hline 132 & 23-Jun-12 & -79.45058356 & 43.673735 & 431 & GLTR & $\begin{array}{r}947 \\
11.811\end{array}$ & 50.524936 & 39.37008 & 11.154856 & 52.496 & 52.496 & 0 & 0 \\
\hline 133 & 23-Jun-12 & -79.45061427 & 43.67386152 & 433 & ACPL & $\begin{array}{r}03 \\
16.929\end{array}$ & 26.574804 & 16.732284 & 9.84252 & 22.967 & 22.967 & 13 & 0 \\
\hline 135 & 23-Jun-12 & -79.45088169 & 43.67387557 & 437 & GLTR & $\begin{array}{r}143 \\
12.204\end{array}$ & 47.244096 & 30.839896 & 16.4042 & 36.091 & 49.215 & 0 & 0 \\
\hline 137 & 23-Jun-12 & -79.45095568 & 43.67399509 & 441 & TICO & $\begin{array}{r}731 \\
2.7559\end{array}$ & 36.08924 & 26.24672 & 9.84252 & 26.248 & 22.967 & 0 & 0 \\
\hline 138 & 23-Jun-12 & -79.45106395 & 43.67405155 & 443 & GLTR & $\begin{array}{r}07 \\
2.3622\end{array}$ & 15.091864 & 7.545932 & 7.545932 & 11.4835 & 9.843 & 33 & 0 \\
\hline 139 & 23-Jun-12 & -79.45118933 & 43.6740523 & 445 & GLTR & $\begin{array}{r}06 \\
11.811\end{array}$ & 14.76378 & 8.2021 & 6.56168 & 13.124 & 13.124 & 28 & 0 \\
\hline 140 & 23-Jun-12 & -79.45102197 & 43.67385567 & 447 & ACPL & $\begin{array}{r}03 \\
14.960\end{array}$ & 34.120736 & 24.278216 & 9.84252 & 26.248 & 26.248 & 0 & 0 \\
\hline 141 & 23-Jun-12 & -79.4511741 & 43.67383213 & 449 & GLTR & $\begin{array}{r}638 \\
30.314\end{array}$ & 39.37008 & 26.24672 & 13.12336 & 43.6373 & 42.653 & 0 & 0 \\
\hline 142 & 23-Jun-12 & -79.45127294 & 43.67389984 & 451 & QUMA1 & $\begin{array}{r}977 \\
20.078\end{array}$ & 73.8189 & 62.33596 & 11.48294 & 59.058 & 65.62 & 0 & 0 \\
\hline 143 & 23-Jun-12 & -79.45133057 & 43.67399543 & 453 & TICO & $\begin{array}{r}751 \\
19.685\end{array}$ & 50.524936 & 40.026248 & 10.498688 & 42.653 & 42.653 & 0 & 0 \\
\hline 144 & 23-Jun-12 & -79.45140065 & 43.67406369 & 455 & ACPL & $\begin{array}{r}05 \\
12.598\end{array}$ & 39.37008 & 30.183728 & 9.186352 & 49.215 & 41.0125 & 18 & 0 \\
\hline 145 & 23-Jun-12 & -79.45143793 & 43.67398551 & 457 & ACPL & $\begin{array}{r}432 \\
27.165\end{array}$ & 30.839896 & 24.278216 & 6.56168 & 32.81 & 36.091 & 38 & 13 \\
\hline 146 & 23-Jun-12 & -79.45150271 & 43.67390485 & 459 & QURU & $\begin{array}{r}369 \\
14.173\end{array}$ & 56.430448 & 47.900264 & 8.530184 & 59.058 & 55.777 & 0 & 0 \\
\hline 147 & 23-Jun-12 & -79.45153105 & 43.67376775 & 461 & PLAC1 & $\begin{array}{r}236 \\
20.866\end{array}$ & 49.2126 & 39.37008 & 9.84252 & 45.934 & 52.496 & 0 & 0 \\
\hline 148 & 23-Jun-12 & -79.4515568 & 43.67368087 & 464 & FRNI & $\begin{array}{r}153 \\
17.322\end{array}$ & 57.086616 & 47.900264 & 9.186352 & 55.777 & 45.934 & 3 & 0 \\
\hline 149 & 23-Jun-12 & -79.45164515 & 43.67359769 & 466 & ACPL & $\begin{array}{r}844 \\
25.984\end{array}$ & 40.026248 & 32.8084 & 7.217848 & 45.934 & 49.215 & 0 & 0 \\
\hline 150 & 23-Jun-12 & -79.45175408 & 43.67388265 & 468 & QURU & $\begin{array}{r}266 \\
27.952\end{array}$ & 58.398952 & 47.244096 & 11.154856 & 45.934 & 62.339 & 0 & 0 \\
\hline 151 & 23-Jun-12 & -79.45173502 & 43.67391273 & 470 & QUAL & $\begin{array}{r}771 \\
18.897\end{array}$ & 72.17848 & 47.57218 & 24.6063 & 49.215 & 59.058 & 13 & 3 \\
\hline 152 & 23-Jun-12 & -79.45191247 & 43.67397108 & 472 & ACPL & $\begin{array}{r}648 \\
18.897\end{array}$ & 52.49344 & 41.994752 & 10.498688 & 52.496 & 45.934 & 0 & 0 \\
\hline 153 & 23-Jun-12 & -79.45204024 & 43.67403159 & 474 & TICO & $\begin{array}{r}648 \\
28.740\end{array}$ & 55.77428 & 41.338584 & 14.435696 & 42.653 & 36.091 & 0 & 0 \\
\hline 154 & 23-Jun-12 & -79.45213978 & 43.67397036 & 476 & QUMA1 & $\begin{array}{r}173 \\
18.503\end{array}$ & 67.585304 & 57.742784 & 9.84252 & 75.463 & 52.496 & 0 & 0 \\
\hline 155 & 23-Jun-12 & -79.45213304 & 43.67408025 & 478 & ACPL & $\begin{array}{r}947 \\
15.354\end{array}$ & 55.118112 & 42.65092 & 12.467192 & 42.653 & 45.934 & 0 & 33 \\
\hline $\begin{array}{l}156 \\
157\end{array}$ & 26-Jun-12 & -79.4519039 & 43.67379651 & 480 & ACPL & $\begin{array}{r}339 \\
26.377 \\
067\end{array}$ & 32.152232 & 24.934384 & 7.217848 & 36.091 & 29.529 & 13 & 8 \\
\hline
\end{tabular}




\begin{tabular}{|c|c|c|c|c|c|c|c|c|c|c|c|c|c|}
\hline 158 & 26-Jun-12 & -79.4519596 & 43.67361143 & 484 & QUAL & $\begin{array}{r}34.645 \\
688\end{array}$ & 78.74016 & 62.33596 & 16.4042 & 82.025 & 75.463 & 0 & 0 \\
\hline 159 & 26-Jun-12 & -79.45208641 & 43.67350601 & 486 & ACPL & $\begin{array}{r}22.440 \\
957 \\
\end{array}$ & 47.900264 & 35.433072 & 12.467192 & 49.215 & 45.934 & 0 & 0 \\
\hline 160 & 26-Jun-12 & -79.45222125 & 43.67359601 & 488 & ACPL & $\begin{array}{r}555 \\
29.527\end{array}$ & 40.682416 & 33.464568 & 7.217848 & 62.339 & 55.777 & 0 & 0 \\
\hline 161 & 26-Jun-12 & -79.45222446 & 43.67387765 & 490 & QUAL & $\begin{array}{r}575 \\
24.409\end{array}$ & 67.585304 & 55.77428 & 11.811024 & 75.463 & 62.339 & 23 & 0 \\
\hline 162 & 26-Jun-12 & -79.45236042 & 43.6738226 & 492 & QUMA1 & $\begin{array}{r}462 \\
31.496\end{array}$ & 73.5236244 & 51.3779544 & 22.14567 & 59.058 & 65.62 & 8 & 0 \\
\hline 163 & 26-Jun-12 & -79.45241375 & 43.67372946 & 495 & QUMA1 & $\begin{array}{r}08 \\
22.834\end{array}$ & 82.021 & 70.209976 & 11.811024 & 65.62 & 68.901 & 0 & 0 \\
\hline 164 & 26-Jun-12 & -79.45227471 & 43.67375223 & 497 & ACPL & $\begin{array}{r}658 \\
22.834\end{array}$ & 59.05512 & 49.2126 & 9.84252 & 52.496 & 55.777 & 0 & 0 \\
\hline 165 & 26-Jun-12 & -79.45258822 & 43.67400583 & 499 & ACPL & $\begin{array}{r}658 \\
28.740\end{array}$ & 45.275592 & 36.08924 & 9.186352 & 67.2605 & 59.058 & 0 & 0 \\
\hline 166 & 26-Jun-12 & -79.45257959 & 43.67383315 & 501 & QUMA1 & $\begin{array}{r}173 \\
20.472\end{array}$ & 68.89764 & 53.149608 & 15.748032 & 62.339 & 65.62 & 28 & 0 \\
\hline 167 & 26-Jun-12 & -79.4527859 & 43.67388714 & 503 & ACPL & $\begin{array}{r}4.47 \\
452 \\
27.165\end{array}$ & 48.556432 & 40.026248 & 8.530184 & 39.372 & 42.653 & 8 & 0 \\
\hline 168 & 26-Jun-12 & -79.45296496 & 43.67403558 & 505 & TICO & $\begin{array}{r}369 \\
25.196\end{array}$ & 47.244096 & 38.057744 & 9.186352 & 55.777 & 42.653 & 0 & 0 \\
\hline 169 & 26-Jun-12 & -79.45312504 & 43.67380451 & 507 & ACSA1 & $\begin{array}{r}864 \\
2.5590\end{array}$ & 73.490816 & 58.398952 & 15.091864 & 65.62 & 62.339 & 0 & 0 \\
\hline 170 & 26-Jun-12 & -79.45333243 & 43.67386705 & 513 & LITU & $\begin{array}{r}565 \\
23.622\end{array}$ & 18.04462 & 10.170604 & 7.874016 & 9.843 & 13.124 & 0 & 0 \\
\hline 171 & 26-Jun-12 & -79.45293534 & 43.67376496 & 511 & ACSA1 & $\begin{array}{r}06 \\
06 \\
17.716\end{array}$ & 63.648296 & 52.49344 & 11.154856 & 65.62 & 45.934 & 18 & 0 \\
\hline 172 & 26-Jun-12 & -79.45300972 & 43.67366642 & 515 & GLTR & $\begin{array}{r}545 \\
16.535\end{array}$ & 41.338584 & 30.183728 & 11.154856 & 47.5745 & 47.5745 & 13 & 0 \\
\hline 173 & 26-Jun-12 & -79.45284824 & 43.67364717 & 517 & PLOC & $\begin{array}{r}442 \\
20.078\end{array}$ & 55.118112 & 46.587928 & 8.530184 & 45.934 & 45.934 & 0 & 0 \\
\hline 174 & 26-Jun-12 & -79.45298698 & 43.67358552 & 519 & ACSA2 & $\begin{array}{r}751 \\
20.472\end{array}$ & 55.118112 & 46.587928 & 8.530184 & 45.934 & 45.934 & 0 & 0 \\
\hline 175 & 26-Jun-12 & -79.45288483 & 43.67349407 & 521 & TICO & $\begin{array}{r}452 \\
20.866\end{array}$ & 41.994752 & 32.8084 & 9.186352 & 39.372 & 36.091 & 0 & 0 \\
\hline 176 & 26-Jun-12 & -79.45277931 & 43.67343196 & 523 & ACPL & $\begin{array}{r}0.000 \\
153 \\
24.015\end{array}$ & 42.65092 & 36.745408 & 5.905512 & 45.934 & 41.0125 & 13 & 13 \\
\hline 177 & 26-Jun-12 & -79.45264043 & 43.67334664 & 525 & TICO & $\begin{array}{r}761 \\
18.307\end{array}$ & 33.464568 & 22.309712 & 11.154856 & 32.81 & 39.372 & 0 & 0 \\
\hline 178 & 26-Jun-12 & -79.45253443 & 43.67330349 & 527 & ACPL & $\begin{array}{r}0965 \\
21.259\end{array}$ & 49.868768 & 32.8084 & 17.060368 & 45.934 & 45.934 & 3 & 0 \\
\hline 179 & 26-Jun-12 & -79.45257086 & 43.67320728 & 529 & ACPL & $\begin{array}{r}854 \\
19.685\end{array}$ & 34.776904 & 28.215224 & 6.56168 & 49.215 & 39.372 & 0 & 0 \\
\hline 180 & 26-Jun-12 & -79.45230437 & 43.67330986 & 531 & ACPL & $\begin{array}{r}05 \\
3.1496\end{array}$ & 36.745408 & 26.902888 & 9.84252 & 45.934 & 49.215 & 28 & 0 \\
\hline 181 & 26-Jun-12 & -79.45241572 & 43.6731957 & 533 & TIAM & $\begin{array}{r}08 \\
18.110\end{array}$ & 14.435696 & 8.2021 & 6.233596 & 13.124 & 11.4835 & 0 & 0 \\
\hline 182 & 26-Jun-12 & -79.45235535 & 43.67310481 & 535 & CASP & $\begin{array}{r}246 \\
23.622\end{array}$ & 32.152232 & 18.372704 & 13.779528 & 32.81 & 36.091 & 33 & 18 \\
\hline 183 & 26-Jun-12 & -79.45226011 & 43.67310067 & 537 & ACSA1 & $\begin{array}{r}06 \\
20.866\end{array}$ & 46.587928 & 34.120736 & 12.467192 & 54.1365 & 49.215 & 43 & 23 \\
\hline 184 & 26-Jun-12 & -79.45235803 & 43.67300055 & 540 & ACPL & $\begin{array}{r}153 \\
19.685\end{array}$ & 41.994752 & 31.496064 & 10.498688 & 45.934 & 36.091 & 13 & 0 \\
\hline 185 & 26-Jun-12 & -79.45208494 & 43.67285179 & 542 & ACPL & $\begin{array}{r}05 \\
19.291\end{array}$ & 43.963256 & 33.464568 & 10.498688 & 45.934 & 39.372 & 0 & 0 \\
\hline 186 & 26-Jun-12 & -79.45156896 & 43.67310648 & 544 & GLTR & $\begin{array}{r}349 \\
14.566\end{array}$ & 48.556432 & 38.057744 & 10.498688 & 49.215 & 65.62 & 0 & 0 \\
\hline 187 & 26-Jun-12 & -79.451518 & 43.67305649 & 546 & GLTR & 937 & 36.745408 & 26.902888 & 9.84252 & 29.529 & 52.496 & 0 & 0 \\
\hline
\end{tabular}




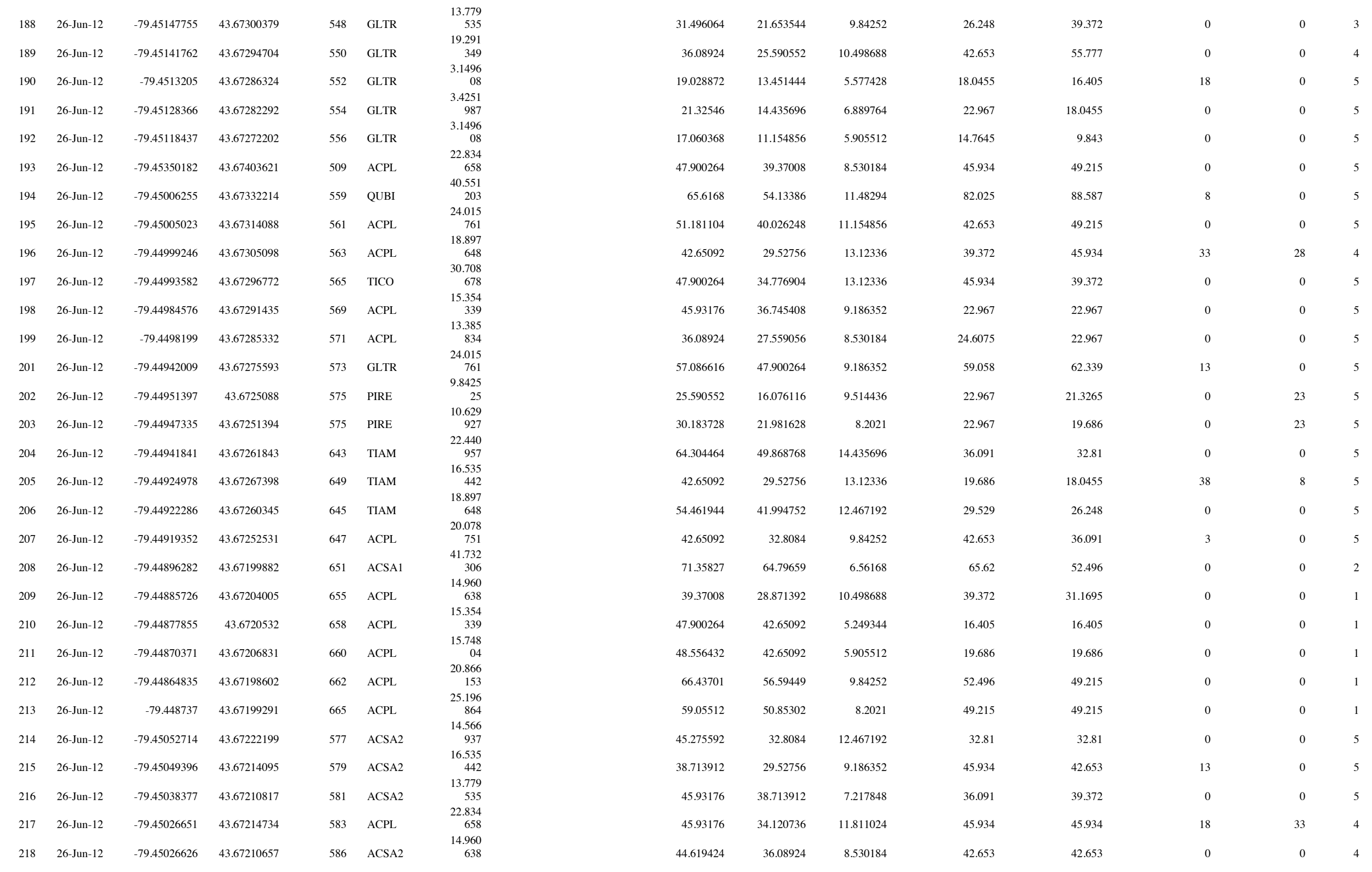




\begin{tabular}{|c|c|c|c|c|c|c|}
\hline 219 & 26-Jun-12 & -79.45025321 & 43.6720552 & 588 & ACSA2 & $\begin{array}{r}21.653 \\
555\end{array}$ \\
\hline & & & & & & 13.779 \\
\hline 220 & 26-Jun-12 & -79.44998344 & 43.67208188 & 590 & GLTR & 535 \\
\hline 221 & 28-Jun-12 & -79.45009651 & 43.67210427 & 593 & TICO & $\begin{array}{r}20.472 \\
452\end{array}$ \\
\hline & 20-7uा-12 & & & & & 17.322 \\
\hline 222 & 28-Jun-12 & -79.45011281 & 43.67218129 & 595 & TIAM & 844 \\
\hline 223 & 28-Jun-12 & -79.4500814 & 43.67228516 & 598 & TIAM & $\begin{array}{r}20.866 \\
153 \\
1\end{array}$ \\
\hline 224 & 28-Jun-12 & -79.45000685 & 43.67218744 & 600 & ACPL & 741 \\
\hline 225 & 28-Jun-12 & -79.44990868 & 43.67229703 & 603 & ACPL & $\begin{array}{r}19.685 \\
05 \\
10.629\end{array}$ \\
\hline 226 & 28-Jun-12 & -79.44981414 & 43.67246831 & 605 & ACSA2 & $\begin{array}{r}927 \\
9566\end{array}$ \\
\hline 227 & 28-Jun-12 & -79.44978662 & 43.67237028 & 607 & PIRE & $\begin{array}{r}937 \\
15354\end{array}$ \\
\hline 228 & 28-Jun-12 & -79.44978966 & 43.67230301 & 609 & PIRE & $\begin{array}{r}339 \\
14960\end{array}$ \\
\hline 229 & 28-Jun-12 & -79.44985088 & 43.67230952 & 611 & PIRE & 638 \\
\hline 230 & 28-Jun-12 & -79.44976453 & 43.67221354 & 613 & ACSA2 & $\begin{array}{r}17.716 \\
545 \\
10.236\end{array}$ \\
\hline 231 & 28-Jun-12 & -79.44983232 & 43.672168 & 616 & FRPE & $\begin{array}{r}226 \\
17.716\end{array}$ \\
\hline 232 & 28-Jun-12 & -79.4497329 & 43.67212304 & 618 & ACPL & $\begin{array}{r}545 \\
23.228\end{array}$ \\
\hline 233 & 28-Jun-12 & -79.45123132 & 43.67226756 & 620 & ACPL & $\begin{array}{r}359 \\
21.653\end{array}$ \\
\hline 234 & 28-Jun-12 & -79.45132588 & 43.67234943 & 622 & ACPL & $\begin{array}{r}555 \\
18.897\end{array}$ \\
\hline 235 & 28-Jun-12 & -79.45131264 & 43.67215299 & 624 & ACPL & $\begin{array}{r}648 \\
20.078\end{array}$ \\
\hline 236 & 28-Jun-12 & -79.45139763 & 43.67209915 & 626 & CASP & $\begin{array}{r}751 \\
18.503\end{array}$ \\
\hline 237 & 28-Jun-12 & -79.45130464 & 43.67205807 & 628 & GLTR & $\begin{array}{r}947 \\
3.1496\end{array}$ \\
\hline 238 & 28-Jun-12 & -79.45114755 & 43.67268075 & 631 & GLTR & $\begin{array}{r}08 \\
27559\end{array}$ \\
\hline 239 & 28-Jun-12 & -79.45110427 & 43.67263655 & 633 & GLTR & $\begin{array}{r}07 \\
2.7559\end{array}$ \\
\hline 240 & 28-Jun-12 & -79.45104826 & 43.67257985 & 635 & GLTR & $\begin{array}{r}07 \\
2.7559\end{array}$ \\
\hline 241 & 28-Jun-12 & -79.45100247 & 43.67253183 & 637 & GLTR & $\begin{array}{r}07 \\
2.7559\end{array}$ \\
\hline 242 & 28-Jun-12 & -79.45093988 & 43.67247694 & 639 & GLTR & $\begin{array}{r}07 \\
2.7559\end{array}$ \\
\hline 243 & 28-Jun-12 & -79.45089148 & 43.67242888 & 641 & GLTR & $\begin{array}{r}07 \\
20.472\end{array}$ \\
\hline 244 & 28-Jun-12 & -79.45156221 & 43.67240383 & 668 & ACPL & $\begin{array}{r}452 \\
20.866\end{array}$ \\
\hline 245 & 28-Jun-12 & -79.45154287 & 43.67224144 & 670 & ACSA2 & $\begin{array}{r}153 \\
24015\end{array}$ \\
\hline 246 & 28-Jun-12 & -79.45111035 & 43.67189236 & 978,979 & FRPE & $\begin{array}{r}761 \\
20.472\end{array}$ \\
\hline 247 & 28-Jun-12 & -79.45098595 & 43.67175225 & 980,981 & GLTR & $\begin{array}{r}452 \\
25.196\end{array}$ \\
\hline 248 & 28-Jun-12 & -79.45096279 & 43.67163722 & 982,983 & ACPL & 864 \\
\hline
\end{tabular}

\begin{tabular}{rrrrr}
51.837272 & 41.338584 & 10.498688 & 45.934 & 49.215 \\
46.587928 & 38.713912 & 7.874016 & 45.934 & 42.653 \\
48.556432 & 40.682416 & 7.874016 & 42.653 & 42.653 \\
41.338584 & 31.496064 & 9.84252 & 36.091 & 39.372 \\
55.118112 & 45.93176 & 9.186352 & 39.372 & 36.091 \\
47.244096 & 40.026248 & 7.217848 & 42.653 & 39.372 \\
41.338584 & 34.120736 & 7.217848 & 55.777 & 52.496 \\
36.08924 & 26.24672 & 9.84252 & 36.091 & 36.091 \\
30.183728 & 19.68504 & 10.498688 & 29.529 & 32.81 \\
32.152232 & 19.68504 & 12.467192 & 32.81 & 26.248 \\
39.37008 & 22.96588 & 16.4042 & 36.091 & 26.248 \\
47.900264 & 37.401576 & 10.498688 & 36.091 & 39.372 \\
51.837272 & 38.713912 & 13.12336 & 45.934 & 45.934 \\
41.338584 & 30.183728 & 11.154856 & 16.405 & 16.405 \\
49.868768 & 40.026248 & 9.84252 & 45.934 & 49.215 \\
46.587928 & 36.745408 & 9.84252 & 26.248 & 29.529 \\
49.2126 & 35.433072 & 13.779528 & 42.653 & 36.091 \\
47.900264 & 44.619424 & 3.28084 & 39.372 & 42.653 \\
43.963256 & 31.496064 & 12.467192 & 45.934 & 42.653 \\
18.700788 & 11.154856 & 7.545932 & 16.405 & 13.124 \\
16.4042 & 11.48294 & 4.92126 & 13.124 & 16.405 \\
\hline 13.12336 & 8.2021 & 4.92126 & 13.124 & 13.124 \\
16.4042 & 13.12336 & 3.28084 & 16.405 & 16.405 \\
19.68504 & 14.76378 & 4.92126 & 13.124 & 13.124 \\
12.795276 & 9.514436 & 3.28084 & 16.405 & 16.405 \\
39.37008 & 29.52756 & 9.84252 & 45.934 & 42.653 \\
37.401576 & 30.183728 & 7.217848 & 49.215 & 49.215 \\
65.6168 & 54.95407 & 10.66273 & 65.62 & 78.744 \\
47.900264 & 36.745408 & 11.154856 & 55.777 & 55.777 \\
49.2126 & 37.72966 & 11.48294 & 39.372 & 45.934
\end{tabular}

\begin{tabular}{|c|c|}
\hline 13 & 0 \\
\hline 0 & 0 \\
\hline 0 & 0 \\
\hline 0 & 0 \\
\hline 0 & 0 \\
\hline 0 & 0 \\
\hline 3 & 0 \\
\hline 43 & 28 \\
\hline 33 & 23 \\
\hline 0 & 38 \\
\hline 0 & 33 \\
\hline 28 & 63 \\
\hline 28 & 0 \\
\hline 0 & 0 \\
\hline 0 & 0 \\
\hline 0 & 0 \\
\hline 0 & 0 \\
\hline 23 & 23 \\
\hline 13 & 0 \\
\hline 0 & 0 \\
\hline 0 & 0 \\
\hline 0 & 0 \\
\hline 0 & 0 \\
\hline 0 & 0 \\
\hline 13 & 0 \\
\hline 13 & 0 \\
\hline 0 & 0 \\
\hline 23 & 0 \\
\hline 13 & 0 \\
\hline 0 & 0 \\
\hline
\end{tabular}




\begin{tabular}{|c|c|c|c|c|c|c|}
\hline 249 & 28-Jun-12 & -79.4508444 & 43.67161854 & 984,985 & GLTR & $\begin{array}{r}22.440 \\
957\end{array}$ \\
\hline 250 & 28-Jun-12 & -79.45069865 & 43.67169905 & 986,987 & ACPL & $\begin{array}{r}22.834 \\
658 \\
6.2992\end{array}$ \\
\hline 251 & 28-Jun-12 & -79.45066127 & 43.67147669 & 988,989 & PINI & $\begin{array}{r}16 \\
18897\end{array}$ \\
\hline 252 & 28-Jun-12 & -79.45057217 & 43.67153806 & 990,991 & GLTR & 648 \\
\hline 253 & 28-Jun-12 & -79.45063878 & 43.67133511 & 992,993 & ACPL & $\begin{array}{r}16.535 \\
442 \\
12.598\end{array}$ \\
\hline 254 & 28-Jun-12 & -79.45084565 & 43.67141756 & 994,995 & PIRE & 432 \\
\hline 255 & 28-Jun-12 & -79.45086452 & 43.67139506 & 998,999 & PIRE & $\begin{array}{r}937 \\
18.110\end{array}$ \\
\hline 256 & 28-Jun-12 & -79.45089181 & 43.67134992 & $\begin{array}{l}996,997 \\
1000,\end{array}$ & PIRE & $\begin{array}{r}246 \\
14.173\end{array}$ \\
\hline 257 & 28-Jun-12 & -79.45081938 & 43.67137264 & $\begin{array}{l}1001 \\
1002\end{array}$ & ACPL & $\begin{array}{r}236 \\
14566\end{array}$ \\
\hline 258 & 28-Jun-12 & -79.45086259 & 43.67136849 & 1003 & PIRE & $\begin{array}{r}937 \\
9803\end{array}$ \\
\hline 259 & 28-Jun-12 & -79.45091117 & 43.67146017 & $\begin{array}{l}1004, \\
1005\end{array}$ & PIRE & $\begin{array}{r}18.503 \\
947\end{array}$ \\
\hline 260 & 28-Jun-12 & -79.45095578 & 43.67140199 & $\begin{array}{l}1006, \\
1007 \\
1043\end{array}$ & PIRE & $\begin{array}{r}13.385 \\
834 \\
16.535\end{array}$ \\
\hline 261 & 28-Jun-12 & -79.45099496 & 43.67135132 & $\begin{array}{l}1044 \\
1045,\end{array}$ & ACPL & $\begin{array}{r}442 \\
12.598\end{array}$ \\
\hline 262 & 28-Jun-12 & -79.45101139 & 43.6714236 & $\begin{array}{l}1046 \\
1447\end{array}$ & PIRE & $\begin{array}{r}432 \\
16141\end{array}$ \\
\hline 263 & 02-Jul-12 & -79.4509989 & 43.67145187 & 1048 & PIRE & $\begin{array}{r}741 \\
24.409\end{array}$ \\
\hline 264 & 02-Jul-12 & -79.45109294 & 43.6714522 & 1100 & ACPL & $\begin{array}{r}462 \\
18110\end{array}$ \\
\hline 265 & 02-Jul-12 & -79.45114487 & 43.67136283 & $\begin{array}{l}1102 \\
1103,\end{array}$ & ACPL & $\begin{array}{r}246 \\
19.291\end{array}$ \\
\hline 266 & 02-Jul-12 & -79.45070334 & 43.67126298 & $\begin{array}{l}1104 \\
1105\end{array}$ & ACPL & $\begin{array}{r}349 \\
18897\end{array}$ \\
\hline 267 & 02-Jul-12 & -79.45042794 & 43.67130571 & $\begin{array}{l}1106 \\
1106 \\
1107\end{array}$ & ACPL & $\begin{array}{r}648 \\
68.740\end{array}$ \\
\hline 268 & 02-Jul-12 & -79.45051539 & 43.67166339 & $\begin{array}{l}1108 \\
1109\end{array}$ & ACPL & $\begin{array}{r}173 \\
20.078\end{array}$ \\
\hline 269 & 02-Jul-12 & -79.45044999 & 43.67151459 & 1110 & PIRE & $\begin{array}{r}751 \\
23622\end{array}$ \\
\hline 270 & 02-Jul-12 & -79.45043643 & 43.67183867 & $\begin{array}{l}1112 \\
1113\end{array}$ & ACPL & $\begin{array}{r}06 \\
18.897\end{array}$ \\
\hline 271 & 02-Jul-12 & -79.45027855 & 43.67183178 & 1114 & ACPL & $\begin{array}{r}648 \\
27165\end{array}$ \\
\hline 272 & 02-Jul-12 & -79.45014254 & 43.67183847 & $\begin{array}{l}1115, \\
1116 \\
1117\end{array}$ & CASP & $\begin{array}{r}27.165 \\
369 \\
25.196\end{array}$ \\
\hline 273 & 02-Jul-12 & -79.45007931 & 43.67170678 & $\begin{array}{l}1118 \\
1119\end{array}$ & ACPL & $\begin{array}{r}864 \\
14.960\end{array}$ \\
\hline 274 & 02-Jul-12 & -79.44987791 & 43.67171637 & $\begin{array}{l}1120 \\
1121,\end{array}$ & FRPE & $\begin{array}{r}638 \\
25.590\end{array}$ \\
\hline 275 & 02-Jul-12 & -79.45022153 & 43.67196659 & $\begin{array}{l}1122 \\
1123, \\
1124,\end{array}$ & ACSA2 & $\begin{array}{r}565 \\
20.866\end{array}$ \\
\hline 276 & 02-Jul-12 & -79.45008495 & 43.67199508 & 1125 & TICO & $\begin{array}{r}153 \\
26377\end{array}$ \\
\hline 277 & 02-Jul-12 & -79.44982426 & 43.67187208 & $\begin{array}{l}1127 \\
1128,\end{array}$ & ACPL & $\begin{array}{r}967 \\
11.811\end{array}$ \\
\hline 278 & 02-Jul-12 & -79.44968433 & 43.67187872 & 1129 & PIRE & 03 \\
\hline
\end{tabular}

\begin{tabular}{|c|c|c|c|c|c|c|}
\hline 50.03281 & 37.72966 & 12.30315 & 65.62 & 55.777 & 0 & 0 \\
\hline 43.963256 & 36.745408 & 7.217848 & 59.058 & 49.215 & 0 & 0 \\
\hline 25.590552 & 23.622048 & 1.968504 & 19.686 & 16.405 & 0 & 0 \\
\hline 48.556432 & 40.682416 & 7.874016 & 55.777 & 52.496 & 0 & 0 \\
\hline 38.057744 & 19.68504 & 18.372704 & 49.215 & 45.934 & 0 & 0 \\
\hline 35.433072 & 19.028872 & 16.4042 & 29.529 & 39.372 & 13 & 0 \\
\hline 27.559056 & 14.435696 & 13.12336 & 22.967 & 19.686 & 13 & 53 \\
\hline 43.307088 & 22.309712 & 20.997376 & 45.934 & 29.529 & 18 & 28 \\
\hline 35.433072 & 26.309212 & 9.12386 & 36.091 & 29.529 & 3 & 3 \\
\hline 40.026248 & 21.653544 & 18.372704 & 22.967 & 16.405 & 0 & 13 \\
\hline 30.183728 & 15.748032 & 14.435696 & 36.091 & 16.405 & 0 & 78 \\
\hline 49.2126 & 26.24672 & 22.96588 & 22.967 & 22.967 & 0 & 68 \\
\hline 42.322836 & 38.385828 & 3.937008 & 39.372 & 39.372 & 0 & 0 \\
\hline 49.2126 & 32.8084 & 16.4042 & 22.967 & 22.967 & 0 & 0 \\
\hline 55.77428 & 41.994752 & 13.779528 & 29.529 & 26.248 & 0 & 33 \\
\hline 51.837272 & 38.057744 & 13.779528 & 42.653 & 42.653 & 0 & 0 \\
\hline 33.464568 & 26.902888 & 6.56168 & 42.653 & 39.372 & 28 & 13 \\
\hline 39.37008 & 30.183728 & 9.186352 & 36.091 & 39.372 & 8 & 0 \\
\hline 49.2126 & 40.026248 & 9.186352 & 39.372 & 42.653 & 0 & 0 \\
\hline 50.524936 & 38.057744 & 12.467192 & 59.058 & 55.777 & 0 & 0 \\
\hline 39.37008 & 32.152232 & 7.217848 & 39.372 & 32.81 & 0 & 28 \\
\hline 49.2126 & 39.37008 & 9.84252 & 49.215 & 49.215 & 0 & 0 \\
\hline 29.52756 & 24.278216 & 5.249344 & 55.777 & 45.934 & 0 & 0 \\
\hline 50.524936 & 42.65092 & 7.874016 & 52.496 & 42.653 & 0 & 0 \\
\hline 55.77428 & 47.57218 & 8.2021 & 59.058 & 49.215 & 0 & 0 \\
\hline 41.338584 & 31.496064 & 9.84252 & 42.653 & 42.653 & 13 & 0 \\
\hline 56.430448 & 45.93176 & 10.498688 & 55.777 & 45.934 & 0 & 0 \\
\hline 48.556432 & 41.338584 & 7.217848 & 49.215 & 42.653 & 0 & 0 \\
\hline 58.398952 & 46.587928 & 11.811024 & 52.496 & 55.777 & 0 & 0 \\
\hline 29.52756 & 24.934384 & 4.593176 & 19.686 & 19.686 & 18 & 13 \\
\hline
\end{tabular}




\begin{tabular}{|c|c|c|c|c|c|c|}
\hline 279 & 02-Jul-12 & -79.44967447 & 43.67195728 & $\begin{array}{l}1130, \\
1131\end{array}$ & AEHI & $\begin{array}{r}25.590 \\
565\end{array}$ \\
\hline 280 & 02-Jul-12 & -79.44961653 & 43.6720769 & 3 & PIRE & $\begin{array}{r}236 \\
15.354\end{array}$ \\
\hline 281 & 02-Jul-12 & -79.44963085 & 43.67202779 & 4 & PIRE & $\begin{array}{r}339 \\
17.716\end{array}$ \\
\hline 282 & 02-Jul-12 & -79.44971051 & 43.67202887 & 5 & FRNI & $\begin{array}{r}545 \\
14.566\end{array}$ \\
\hline 283 & 02-Jul-12 & -79.44975185 & 43.67164071 & 7 & CASP & $\begin{array}{r}937 \\
5.9055\end{array}$ \\
\hline 284 & 02-Jul-12 & -79.44994051 & 43.67161861 & 9 & PIST & $\begin{array}{r}15 \\
23.228\end{array}$ \\
\hline 285 & 02-Jul-12 & -79.4499923 & 43.67153493 & 11 & TICO & $\begin{array}{r}359 \\
16.535\end{array}$ \\
\hline 286 & 02-Jul-12 & -79.44987107 & 43.67147451 & 13 & FRNI & $\begin{array}{r}442 \\
18.110\end{array}$ \\
\hline 287 & 02-Jul-12 & -79.44983706 & 43.67142569 & 15 & ACPL & $\begin{array}{r}246 \\
8.6614\end{array}$ \\
\hline 288 & 02-Jul-12 & -79.4501043 & 43.67154783 & 17 & PIST & $\begin{array}{r}22 \\
23.622\end{array}$ \\
\hline 289 & 02-Jul-12 & -79.45019332 & 43.67148931 & 19 & FRPE & $\begin{array}{r}06 \\
5.9055\end{array}$ \\
\hline 290 & 02-Jul-12 & -79.45031264 & 43.67142076 & 21 & QUMA1 & $\begin{array}{r}15 \\
5.9055\end{array}$ \\
\hline 291 & 02-Jul-12 & -79.45018665 & 43.67139346 & 23 & PIST & $\begin{array}{r}15 \\
6.6929\end{array}$ \\
\hline 292 & 02-Jul-12 & -79.44999395 & 43.67142023 & 25 & QUMA1 & $\begin{array}{r}17 \\
19.685\end{array}$ \\
\hline 294 & 02-Jul-12 & -79.4494209 & 43.67150727 & 28 & PLAC1 & $\begin{array}{r}05 \\
28.346\end{array}$ \\
\hline 295 & 02-Jul-12 & -79.44950237 & 43.67158992 & 30 & GYDI & $\begin{array}{r}472 \\
27.559\end{array}$ \\
\hline 296 & 02-Jul-12 & -79.44965992 & 43.67150767 & 32 & TICO & $\begin{array}{r}07 \\
27.952\end{array}$ \\
\hline 297 & 02-Jul-12 & -79.44982158 & 43.67157054 & 34 & ACPL & $\begin{array}{r}771 \\
22.047\end{array}$ \\
\hline 298 & 02-Jul-12 & -79.44980577 & 43.67152482 & 36 & ACPL & $\begin{array}{r}256 \\
16.141\end{array}$ \\
\hline 299 & 02-Jul-12 & -79.44970822 & 43.67155952 & 38 & ACPL & $\begin{array}{r}741 \\
25.590\end{array}$ \\
\hline 300 & 02-Jul-12 & -79.44932422 & 43.67160931 & 40 & AEHI & $\begin{array}{r}565 \\
18.897\end{array}$ \\
\hline 301 & 02-Jul-12 & -79.44920198 & 43.67153749 & 42 & PLAC1 & $\begin{array}{r}648 \\
22.440\end{array}$ \\
\hline 302 & 02-Jul-12 & -79.44910797 & 43.67163766 & 44 & ACPL & $\begin{array}{r}957 \\
19.291\end{array}$ \\
\hline 303 & 02-Jul-12 & -79.44892823 & 43.6716684 & 46 & ACPL & $\begin{array}{r}349 \\
20.472\end{array}$ \\
\hline 304 & 02-Jul-12 & -79.44897805 & 43.6716103 & 48 & PLAC1 & $\begin{array}{r}452 \\
25.196\end{array}$ \\
\hline 305 & 02-Jul-12 & -79.44880974 & 43.67160327 & 50 & PLAC1 & $\begin{array}{r}864 \\
3.9370\end{array}$ \\
\hline 306 & 02-Jul-12 & -79.44891565 & 43.67159902 & 52 & FRPE & $\begin{array}{r}1 \\
3.5433\end{array}$ \\
\hline 307 & $02-J u l-1$ & -79.44876076 & 43.67162821 & 54 & ALEX1 & $\begin{array}{r}09 \\
3.1496\end{array}$ \\
\hline 308 & $02-$ & 4878528 & 43.67 & 56 & ALEX1 & $\begin{array}{r}08 \\
3.9370\end{array}$ \\
\hline 309 & 02-Jul-12 & -79.44881093 & 43.67165828 & 58 & ALEX1 & 1 \\
\hline
\end{tabular}

\begin{tabular}{|c|c|c|c|c|}
\hline 55.77428 & 45.93176 & 9.84252 & 52.496 & 49.215 \\
\hline 36.08924 & 26.24672 & 9.84252 & 26.248 & 36.091 \\
\hline 42.65092 & 26.24672 & 16.4042 & 32.81 & 32.81 \\
\hline 55.77428 & 45.93176 & 9.84252 & 32.81 & 45.934 \\
\hline 42.65092 & 32.8084 & 9.84252 & 22.967 & 29.529 \\
\hline 26.24672 & 22.96588 & 3.28084 & 16.405 & 16.405 \\
\hline 49.2126 & 42.65092 & 6.56168 & 49.215 & 49.215 \\
\hline 45.93176 & 39.37008 & 6.56168 & 32.81 & 32.81 \\
\hline 44.619424 & 36.08924 & 8.530184 & 39.372 & 42.653 \\
\hline 40.682416 & 37.401576 & 3.28084 & 29.529 & 22.967 \\
\hline 61.679792 & 53.149608 & 8.530184 & 49.215 & 55.777 \\
\hline 27.88714 & 21.32546 & 6.56168 & 13.124 & 14.7645 \\
\hline 19.356956 & 17.060368 & 2.296588 & 13.124 & 11.4835 \\
\hline 20.013124 & 17.388452 & 2.624672 & 13.124 & 16.405 \\
\hline 43.963256 & 36.08924 & 7.874016 & 32.81 & 39.372 \\
\hline 85.30184 & 63.97638 & 21.32546 & 72.182 & 75.463 \\
\hline 55.77428 & 46.75197 & 9.02231 & 59.058 & 45.934 \\
\hline 56.430448 & 49.2126 & 7.217848 & 65.62 & 65.62 \\
\hline 68.89764 & 61.679792 & 7.217848 & 62.339 & 62.339 \\
\hline 19.68504 & 11.811024 & 7.874016 & 32.81 & 32.81 \\
\hline 53.805776 & 50.524936 & 3.28084 & 42.653 & 45.934 \\
\hline 61.679792 & 52.49344 & 9.186352 & 49.215 & 49.215 \\
\hline 68.89764 & 65.6168 & 3.28084 & 62.339 & 65.62 \\
\hline 61.8766424 & 56.59449 & 5.2821524 & 52.496 & 49.215 \\
\hline 57.742784 & 44.619424 & 13.12336 & 45.934 & 49.215 \\
\hline 51.181104 & 43.963256 & 7.217848 & 59.058 & 52.496 \\
\hline 21.653544 & 14.9606304 & 6.6929136 & 14.7645 & 14.7645 \\
\hline 22.309712 & 11.154856 & 11.154856 & 19.686 & 13.124 \\
\hline 37.073492 & 28.871392 & 8.2021 & 6.562 & 6.562 \\
\hline 26.902888 & 20.341208 & 6.56168 & 9.843 & 6.562 \\
\hline
\end{tabular}

\begin{tabular}{|c|c|}
\hline 0 & 0 \\
\hline 8 & 0 \\
\hline 8 & 0 \\
\hline 0 & 0 \\
\hline 0 & 0 \\
\hline 0 & 0 \\
\hline 0 & 0 \\
\hline 0 & 0 \\
\hline 0 & 58 \\
\hline 0 & 0 \\
\hline 23 & 0 \\
\hline 0 & 0 \\
\hline 0 & 0 \\
\hline 0 & 0 \\
\hline 0 & 0 \\
\hline 33 & 18 \\
\hline 0 & 0 \\
\hline 0 & 0 \\
\hline 0 & 0 \\
\hline 0 & 0 \\
\hline 33 & 0 \\
\hline 0 & 23 \\
\hline 0 & 8 \\
\hline 0 & 13 \\
\hline 0 & 0 \\
\hline 0 & 33 \\
\hline 0 & 28 \\
\hline 18 & 0 \\
\hline 3 & 0 \\
\hline 0 & 88 \\
\hline
\end{tabular}




\begin{tabular}{|c|c|c|c|c|c|c|c|c|c|c|c|c|c|c|c|c|}
\hline 310 & 02-Jul-12 & -79.44875902 & 43.67164525 & 60 & ALEX1 & $\begin{array}{r}4.5275 \\
615 \\
10.629\end{array}$ & & & & 35.761156 & 25.918636 & 9.84252 & 16.405 & 13.124 & 0 & 73 \\
\hline 311 & 02-Jul-12 & -79.44869228 & 43.67165003 & 62 & $\mathrm{ACNE}$ & 927 & & & & 49.868768 & 33.464568 & 16.4042 & 26.248 & 42.653 & 0 & 63 \\
\hline 312 & 02-Jul-12 & -79.44873811 & 43.67169616 & 64 & ACNE & $\begin{array}{r}3.5433 \\
09 \\
33622\end{array}$ & $\begin{array}{r}3.9370 \\
1\end{array}$ & $\begin{array}{r}3.1496 \\
08\end{array}$ & & 34.776904 & 28.215224 & 6.56168 & 19.686 & 26.248 & 18 & 0 \\
\hline 313 & 02-Jul-12 & -79.448669924 & 43.6716317 & 66 & $\mathrm{ACNE}$ & $\begin{array}{r}.526 \\
06 \\
3.5433\end{array}$ & & & & 18.04462 & 11.811024 & 6.233596 & 6.562 & 9.843 & 0 & 0 \\
\hline 314 & 02-Jul-12 & -79.44859762 & 43.67162315 & 68 & JUNI & $\begin{array}{r}09 \\
3.9370\end{array}$ & & & & 28.543308 & 22.96588 & 5.577428 & 9.843 & 9.843 & 13 & 13 \\
\hline 315 & 02-Jul-12 & -79.4485737 & 43.67163894 & 70 & ALEX1 & $\begin{array}{r}1 \\
3.9370\end{array}$ & & & & 24.934384 & 17.716536 & 7.217848 & 19.686 & 16.405 & 0 & 18 \\
\hline 316 & 02-Jul-12 & -79.44853897 & 43.67166881 & 72 & ALEX1 & $\begin{array}{r}1 \\
18.464\end{array}$ & & & & 23.950132 & 16.076116 & 7.874016 & 13.124 & 16.405 & 0 & 18 \\
\hline 317 & 02-Jul-12 & -79.4487083 & 43.67189012 & 74 & ALEX1 & $\begin{array}{r}5769 \\
5.5118\end{array}$ & & & & 54.13386 & 44.29134 & 9.84252 & 39.372 & 59.058 & 0 & 0 \\
\hline 318 & 02-Jul-12 & -79.4494019 & 43.67178861 & 76 & JUNI & $\begin{array}{r}14 \\
7.4803\end{array}$ & & & & 35.433072 & 23.950132 & 11.48294 & 26.248 & 26.248 & 0 & 33 \\
\hline 319 & 02-Jul-12 & -79.44934929 & 43.67175186 & 78 & JUNI & $\begin{array}{r}19 \\
6.2992\end{array}$ & & & & 48.884516 & 39.041996 & 9.84252 & 26.248 & 26.248 & 0 & 0 \\
\hline 320 & 02-Jul-12 & -79.44931149 & 43.67174851 & 80 & ALEX1 & $\begin{array}{r}16 \\
5.5118\end{array}$ & & & & 26.574804 & 24.6063 & 1.968504 & 16.405 & 19.686 & 0 & 0 \\
\hline 321 & 02-Jul-12 & -79.44927161 & 43.67167401 & 82 & ALEX1 & $\begin{array}{r}14 \\
5.5118\end{array}$ & & & & 25.9842528 & 21.5551188 & 4.429134 & 16.405 & 9.843 & 0 & 0 \\
\hline 322 & 02-Jul-12 & -79.44926264 & 43.6717687 & 84 & JUNI & $\begin{array}{r}14 \\
3.5433\end{array}$ & & & & 38.877954 & 32.972442 & 5.905512 & 19.686 & 32.81 & 0 & 98 \\
\hline 323 & 02-Jul-12 & -79.44926534 & 43.6717147 & 86 & ALEX1 & $\begin{array}{r}09 \\
14566\end{array}$ & & & & 22.0472448 & 17.9133864 & 4.1338584 & 14.7645 & 13.124 & 0 & 0 \\
\hline 324 & 02-Jul-12 & -79.44930998 & 43.67180727 & 88 & ACPL & $\begin{array}{r}937 \\
3.1496\end{array}$ & & & & 47.408138 & 37.9265104 & 9.4816276 & 42.653 & 39.372 & 0 & 83 \\
\hline 325 & 02-Jul-12 & -79.44920189 & 43.67164273 & 90 & ALEX1 & $\begin{array}{r}08 \\
23622\end{array}$ & & & & 20.997376 & 14.107612 & 6.889764 & 13.124 & 13.124 & 0 & 13 \\
\hline 326 & 02-Jul-12 & -79.44920746 & 43.67167978 & 92 & ULPU & $\begin{array}{r}06 \\
06 \\
14.173\end{array}$ & & & & 33.464568 & 26.574804 & 6.889764 & 13.124 & 13.124 & 0 & 13 \\
\hline 327 & 02-Jul-12 & -79.44921495 & 43.67169315 & 94 & FRPE & $\begin{array}{r}236 \\
2.3622\end{array}$ & & & & 45.767718 & 36.90945 & 8.858268 & 42.653 & 36.091 & 0 & 33 \\
\hline 328 & 02-Jul-12 & -79.44914822 & 43.67169794 & 96 & JUNI & $\begin{array}{r}06 \\
3.5433\end{array}$ & & & & 23.293964 & 15.091864 & 8.2021 & 13.124 & 13.124 & 0 & 43 \\
\hline 329 & 02-Jul-12 & -79.44916953 & 43.67173236 & 98 & ALEX1 & $\begin{array}{r}09 \\
3.5433\end{array}$ & & & & 47.244096 & 34.8425208 & 12.4015752 & 14.7645 & 9.843 & 48 & 0 \\
\hline 330 & 02-Jul-12 & -79.44916652 & 43.67179869 & 100 & ALEX1 & $\begin{array}{r}09 \\
3.1496\end{array}$ & & & & 38.4842532 & 29.5603684 & 8.9238848 & 16.405 & 9.843 & 33 & 0 \\
\hline 331 & 02-Jul-12 & -79.44917977 & 43.67179128 & 102 & ALEX1 & $\begin{array}{r}08 \\
3.1496\end{array}$ & & & & 35.433072 & 27.559056 & 7.874016 & 13.124 & 9.843 & 23 & 68 \\
\hline 332 & 02-Jul-12 & -79.44914952 & 43.6717994 & 104 & $\mathrm{ACNE}$ & $\begin{array}{r}08 \\
2.7559\end{array}$ & & & & 40.354332 & 26.082678 & 14.271654 & 13.124 & 13.124 & 13 & 63 \\
\hline 333 & 02-Jul-12 & -79.44909922 & 43.67182527 & 106 & ALEX1 & $\begin{array}{r}07 \\
5.1181\end{array}$ & & & & 26.24672 & 21.32546 & 4.92126 & 9.843 & 9.843 & 0 & 0 \\
\hline 334 & 04-Jul-12 & -79.44908722 & 43.67183459 & 108 & FRPE & $\begin{array}{r}13 \\
3.1496\end{array}$ & & & & 32.8084 & 24.6063 & 8.2021 & 19.686 & 19.686 & 13 & 18 \\
\hline 335 & 04-Jul-12 & -79.44911043 & 43.67184628 & 110 & ALEX1 & $\begin{array}{r}08 \\
3.1496\end{array}$ & & & & 33.792652 & 28.871392 & 4.92126 & 11.4835 & 13.124 & 13 & 33 \\
\hline 336 & 04-Jul-12 & -79.44911203 & 43.67173347 & 112 & ALEX1 & $\begin{array}{r}08 \\
3.1496\end{array}$ & 2.3622 & 1.1811 & 0.7874 & 33.792652 & 27.559056 & 6.233596 & 13.124 & 9.843 & 23 & 33 \\
\hline 337 & 04-Jul-12 & -79.44912734 & 43.6717479 & 114 & QUMA1 & $\begin{array}{r}08 \\
4.3307\end{array}$ & 06 & 03 & 02 & 29.52756 & 24.6063 & 4.92126 & 11.4835 & 16.405 & 23 & 83 \\
\hline 338 & 04-Jul-12 & -79.44908632 & 43.67176821 & 116 & FRPE & $\begin{array}{r}11 \\
4.7244\end{array}$ & & & & 33.464568 & 28.543308 & 4.92126 & 16.405 & 19.686 & 23 & 83 \\
\hline 339 & 04-Jul-12 & -79.44906681 & 43.6717651 & 118 & ALEX1 & 12 & & & & 30.839896 & 17.716536 & 13.12336 & 13.124 & 16.405 & 38 & 63 \\
\hline
\end{tabular}




\begin{tabular}{|c|c|c|c|c|c|c|c|c|}
\hline 340 & 04-Jul-12 & -79.44900313 & 43.67170166 & 120 & JUNI & $\begin{array}{r}4.3307 \\
11\end{array}$ & $\begin{array}{r}1.9685 \\
05\end{array}$ & \\
\hline & & & & & & 3.9370 & 1.9685 & \\
\hline 341 & 04-Jul-12 & $-19.44895 / 14$ & 43.67171241 & 122 & ALEX1 & 1 & 05 & \\
\hline 342 & 04-Jul-12 & -79.44902 & 43.67175688 & 124 & ACNE & 12 & & \\
\hline & & & & & & 3.1496 & & \\
\hline 343 & 04-Jul-12 & -79.44897122 & 43.67177423 & 126 & ALEX1 & 08 & & \\
\hline 344 & 04-Jul-12 & -79.44896242 & 43.67176083 & 128 & ACPL & $\begin{array}{r}15.354 \\
339\end{array}$ & & \\
\hline 345 & 04-Jul-12 & -79.44899519 & 43.67185799 & 132 & ACPL & $\begin{array}{r}7.4803 \\
19\end{array}$ & $\begin{array}{r}5.5118 \\
14\end{array}$ & \\
\hline & & & & & & 4.7244 & & \\
\hline 346 & 04-Jul-12 & -79.44891601 & 43.67188915 & 134 & ULPU & $\begin{array}{r}12 \\
2.7559\end{array}$ & & \\
\hline 347 & 04-Jul-12 & -79.44894285 & 43.67181082 & 136 & ALEX1 & 07 & & \\
\hline 348 & 04-Jul-12 & -79.44891849 & 43.67174222 & 138 & ULPU & $\begin{array}{r}5.9055 \\
15 \\
70.66\end{array}$ & & \\
\hline 349 & 04-Jul-12 & -79.44892538 & 43.6717281 & 140 & ULPU & $\begin{array}{r}18 \\
6.2992\end{array}$ & & \\
\hline 350 & 04-Jul-12 & -79.44887839 & 43.67177771 & 142 & ULPU & $\begin{array}{r}16 \\
3.1496\end{array}$ & & \\
\hline 351 & 04-Jul-12 & -79.4488699 & 43.67180319 & 144 & ACPL & $\begin{array}{r}08 \\
35433\end{array}$ & & \\
\hline 352 & 04-Jul-12 & -79.4487412 & 43.67182989 & 146 & ACPL & 09 & & \\
\hline 353 & 04-Jul-12 & -79.44875948 & 43.67183014 & 148 & ACNE & & $\begin{array}{r}1.5748 \\
04\end{array}$ & $\begin{array}{r}1.5748 \\
04\end{array}$ \\
\hline 354 & 04-Jul-12 & -79.44878963 & 43.67182581 & 150 & FRPE & $\begin{array}{r}.1496 \\
08 \\
6.6929\end{array}$ & & \\
\hline 355 & 04-Jul-12 & -79.44875889 & 43.67185288 & 152 & PIST & 17 & & \\
\hline 356 & 04-Jul-12 & -79.44876254 & 43.67186336 & 154 & FRNI & $\begin{array}{r}.1496 \\
08\end{array}$ & & \\
\hline 357 & 04-Jul-12 & -79.44874895 & 43.67188404 & 156 & QUBI & $\begin{array}{r}41.732 \\
306\end{array}$ & & \\
\hline & & & & & & 10.236 & & \\
\hline 358 & 04-Jul-12 & -79.44881209 & 43.67186688 & 158 & PIRE & 226 & & \\
\hline & & & & & & 10.236 & & \\
\hline 359 & 04-Jul-12 & -79.44884986 & 43.67187119 & 160 & PIRE & 226 & & \\
\hline 360 & 04-Jul-12 & -79.44887295 & 43.67188762 & 162 & PIRE & $\begin{array}{r}10.629 \\
927\end{array}$ & & \\
\hline 361 & 04-Jul-12 & -79.44880734 & 43.67169615 & 164 & PIRE & $\begin{array}{r}14.960 \\
638 \\
630\end{array}$ & & \\
\hline 362 & 04-Jul-12 & -79.4484649 & 43.67170478 & 166 & PIRE & 143 & & \\
\hline 363 & 04-Jul-12 & -79.44852008 & 43.67169225 & 168 & PIRE & $\begin{array}{r}927 \\
47244\end{array}$ & & \\
\hline 364 & 04-Jul-12 & -79.44866435 & 43.67166956 & 170 & QURU & $\begin{array}{r}12 \\
39370\end{array}$ & & \\
\hline 365 & 04-Jul-12 & -79.44857507 & 43.67168731 & 672,673 & ACFR & $\begin{array}{r}1 \\
3.9370\end{array}$ & & \\
\hline 366 & 04-Jul-12 & -79.44861966 & 43.67168033 & 674,677 & QURU & $\begin{array}{r}1 \\
4.3307\end{array}$ & & \\
\hline 367 & 04-Jul-12 & -79.44859843 & 43.67191586 & 678,679 & ACFR & 11 & & \\
\hline 368 & 04-Jul-12 & -79.44854556 & 43.67192041 & $\begin{array}{l}680,681 \\
682,683\end{array}$ & ACFR & $\begin{array}{r}.1181 \\
13 \\
2.7559\end{array}$ & & \\
\hline 369 & 04-Jul-12 & -79.44851781 & 43.67192242 & $\begin{array}{l}682,683, \\
684\end{array}$ & PIST & $\begin{array}{r}2.7559 \\
07\end{array}$ & & \\
\hline
\end{tabular}

\begin{tabular}{|c|c|c|c|c|c|c|}
\hline 19.68504 & 14.76378 & 4.92126 & 13.124 & 13.124 & 0 & 38 \\
\hline 36.08924 & 30.511812 & 5.577428 & 16.405 & 14.7645 & 0 & 43 \\
\hline 30.511812 & 23.950132 & 6.56168 & 22.967 & 22.967 & 33 & 48 \\
\hline 21.981628 & 15.419948 & 6.56168 & 19.686 & 16.405 & 0 & 0 \\
\hline 48.556432 & 38.057744 & 10.498688 & 26.248 & 39.372 & 18 & 0 \\
\hline 48.556432 & 38.057744 & 10.498688 & 19.686 & 29.529 & 0 & 0 \\
\hline 30.019686 & 21.161418 & 8.858268 & 19.686 & 22.967 & 0 & 0 \\
\hline 22.96588 & 13.12336 & 9.84252 & 9.843 & 8.2025 & 0 & 38 \\
\hline 35.104988 & 26.902888 & 8.2021 & 21.3265 & 14.7645 & 0 & 43 \\
\hline 34.44882 & 24.6063 & 9.84252 & 17.3893 & 19.0298 & 0 & 0 \\
\hline 35.433072 & 29.199476 & 6.233596 & 16.7331 & 14.1083 & 0 & 0 \\
\hline 22.96588 & 16.1391 & 6.8267 & 10.8273 & 10.4992 & 0 & 18 \\
\hline 21.32546 & 18.6063 & 2.71916 & 10.4992 & 13.124 & 0 & 0 \\
\hline 32.152232 & 25.590552 & 6.56168 & 21.3265 & 26.248 & 0 & 28 \\
\hline 31.16798 & 21.32546 & 9.84252 & 8.2025 & 6.562 & 0 & 68 \\
\hline 32.8084 & 26.24672 & 6.56168 & 13.124 & 13.124 & 0 & 0 \\
\hline 27.230972 & 19.68504 & 7.545932 & 11.4835 & 13.124 & 0 & 13 \\
\hline 98.4252 & 68.89764 & 29.52756 & 82.025 & 82.025 & 0 & 0 \\
\hline 43.963256 & 27.559056 & 16.4042 & 18.0455 & 22.967 & 13 & 13 \\
\hline 43.307088 & 33.464568 & 9.84252 & 19.686 & 26.248 & 8 & 13 \\
\hline 40.026248 & 26.24672 & 13.779528 & 16.405 & 26.248 & 13 & 68 \\
\hline 49.868768 & 28.215224 & 21.653544 & 22.967 & 42.653 & 13 & 73 \\
\hline 51.181104 & 36.08924 & 15.091864 & 26.248 & 36.091 & 13 & 38 \\
\hline 40.682416 & 27.559056 & 13.12336 & 19.686 & 19.686 & 8 & 48 \\
\hline 24.278216 & 22.96588 & 1.312336 & 18.3736 & 16.405 & 13 & 43 \\
\hline 23.950132 & 20.669292 & 3.28084 & 13.124 & 18.7017 & 0 & 0 \\
\hline 25.262468 & 20.013124 & 5.249344 & 15.7488 & 13.124 & 0 & 0 \\
\hline 30.511812 & 22.14567 & 8.366142 & 12.1397 & 10.8273 & 0 & 0 \\
\hline 30.019686 & 20.669292 & 9.350394 & 13.124 & 12.4678 & 0 & 0 \\
\hline 15.748032 & 14.435696 & 1.312336 & 8.8587 & 9.1868 & 0 & 0 \\
\hline
\end{tabular}




\begin{tabular}{|c|c|c|c|c|c|c|c|c|}
\hline 370 & 04-Jul-12 & -79.44860579 & 43.67191165 & $\begin{array}{l}686,687, \\
688\end{array}$ & PIST & $\begin{array}{r}3.5433 \\
09\end{array}$ & & \\
\hline & & & & & & 3.9370 & & \\
\hline 371 & 04-Jul-12 & -79.44862204 & 43.67189512 & 689,690 & PIST & 1 & & \\
\hline 372 & 04-Jul-12 & -79.44853635 & 43.67189396 & 691,692 & QURU & $\begin{array}{r}3.9370 \\
1\end{array}$ & & \\
\hline 373 & & & & & OUPH & 4.3307 & & \\
\hline 3/3 & 04-Jul-12 & -79.44851192 & 43.67189506 & 693,694 & QURU & 11 & & \\
\hline 374 & 04-Jul-12 & -79.44849614 & 43.67189341 & 695,696 & GYDI & $\begin{array}{r}3.5433 \\
09\end{array}$ & & \\
\hline 375 & 04-Jul-12 & -79.44864658 & 43.67191508 & 697,698 & ACPL & $\begin{array}{r}0.930 \\
1 \\
5.1181\end{array}$ & & \\
\hline 376 & 04-Jul-12 & -79.44870554 & 43.67190439 & 699,700 & ACFR & $\begin{array}{r}13 \\
7.8740\end{array}$ & & \\
\hline 377 & 04-Jul-12 & -79.44869258 & 43.6718956 & 702,703 & ACFR & $\begin{array}{r}2 \\
5.1181\end{array}$ & & \\
\hline 378 & 04-Jul-12 & -79.44869227 & 43.67188219 & 704,705 & QURU & $\begin{array}{r}13 \\
4.7244\end{array}$ & & \\
\hline 379 & 04-Jul-12 & -79.44865487 & 43.67190035 & 706,707 & QURU & $\begin{array}{r}12 \\
4.7244\end{array}$ & & \\
\hline 380 & 04-Jul-12 & -79.44878247 & 43.67170824 & 708,709 & ACFR & $\begin{array}{r}12 \\
39370\end{array}$ & & \\
\hline 381 & 04-Jul-12 & -79.44875327 & 43.6717155 & 710,711 & ACSA1 & $\begin{array}{r}1 \\
7.0866\end{array}$ & & \\
\hline 382 & 04-Jul-12 & -79.44870843 & 43.67171537 & 712,713 & ACFR & $\begin{array}{r}18 \\
6.6929\end{array}$ & & \\
\hline 383 & 04-Jul-12 & -79.44861764 & 43.67173329 & 714,715 & ACFR & $\begin{array}{r}17 \\
4.7244\end{array}$ & & \\
\hline 384 & 04-Jul-12 & -79.44852004 & 43.6717334 & $\begin{array}{l}716,717 \\
718,719\end{array}$ & ACSA 1 & $\begin{array}{r}12 \\
3.1496\end{array}$ & 3.1496 & 2.3622 \\
\hline 385 & 04-Jul-12 & -79.44850523 & 43.67174516 & & ACSA1 & $\begin{array}{r}08 \\
0.7244\end{array}$ & 08 & 06 \\
\hline 386 & 04-Jul-12 & -79.44866829 & 43.6717378 & 721,722 & PIST & 12 & & \\
\hline 387 & 04-Jul-12 & -79.44868592 & 43.67174474 & $\begin{array}{l}723,724 \\
75.527\end{array}$ & ACFR & $\begin{array}{r}4.7244 \\
12\end{array}$ & $\begin{array}{r}4.7244 \\
12\end{array}$ & $\begin{array}{r}4.7244 \\
12\end{array}$ \\
\hline 388 & 04-Jul-12 & -79.44877776 & 43.67173737 & $\begin{array}{l}725,726, \\
727\end{array}$ & ACSA2 & $\begin{array}{r}2.4015 \\
761 \\
4.3307\end{array}$ & & \\
\hline 389 & 04-Jul-12 & -79.44878588 & 43.67175519 & 728,729 & QURU & $\begin{array}{r}11 \\
2.7559\end{array}$ & & \\
\hline 390 & 04-Jul-12 & -79.44877333 & 43.67178135 & 730,731 & ACFR & 07 & & \\
\hline 391 & 04-Jul-12 & -79.44875657 & 43.67179213 & $\begin{array}{l}732,733, \\
734 \\
732.733\end{array}$ & ACNE & $\begin{array}{r}5.1181 \\
13 \\
5955\end{array}$ & & \\
\hline 392 & 04-Jul-12 & -79.4487363 & 43.67175978 & 734 & PIST & $\begin{array}{r}5.9055 \\
15 \\
4.7244\end{array}$ & & \\
\hline 393 & 04-Jul-12 & -79.4487183 & 43.67179304 & 735,736 & ACNE & $\begin{array}{r}12 \\
12 \\
3.9370\end{array}$ & & \\
\hline 394 & 04-Jul-12 & -79.44869012 & 43.67181181 & 737,739 & QURU & $\begin{array}{r}1 \\
3.5433\end{array}$ & & \\
\hline 395 & 07-Jul-12 & -79.44870267 & 43.67183687 & 740,741 & ACSA 1 & $\begin{array}{r}09 \\
3.1496\end{array}$ & & \\
\hline 396 & 07-Jul-12 & -79.44863907 & 43.6718226 & 742,743 & QUMA1 & 08 & & \\
\hline 397 & 07-Jul-12 & -79.44864746 & 43.67185526 & 744,745 & ACSA1 & $\begin{array}{r}3.5433 \\
09\end{array}$ & $\begin{array}{r}3.5433 \\
09\end{array}$ & \\
\hline 398 & 07-Jul-12 & -79.44858852 & 43.67183962 & $\begin{array}{l}746,747, \\
748\end{array}$ & ACSA1 & $\begin{array}{r}3.5433 \\
09\end{array}$ & $\begin{array}{r}2.3622 \\
06\end{array}$ & $\begin{array}{r}1.1811 \\
03\end{array}$ \\
\hline 399 & 07-Jul-12 & -79.44855377 & 43.67178076 & 749,750 & QURU & $\begin{array}{r}4.7244 \\
12\end{array}$ & & \\
\hline
\end{tabular}

\begin{tabular}{|c|c|c|c|c|c|c|}
\hline 15.748032 & 12.467192 & 3.28084 & 9.843 & 9.843 & 0 & 0 \\
\hline 19.68504 & 16.732284 & 2.952756 & 9.843 & 10.4992 & 0 & 0 \\
\hline 18.700788 & 12.795276 & 5.905512 & 12.1397 & 13.124 & 0 & 0 \\
\hline 20.669292 & 17.060368 & 3.608924 & 13.124 & 12.4678 & 0 & 0 \\
\hline 25.590552 & 19.192914 & 6.397638 & 14.1083 & 13.124 & 0 & 0 \\
\hline 11.154856 & 9.186352 & 1.968504 & 7.2182 & 7.8744 & 0 & 0 \\
\hline 34.44882 & 27.06693 & 7.38189 & 15.7488 & 13.124 & 0 & 0 \\
\hline 42.322836 & 34.940946 & 7.38189 & 20.0141 & 20.0141 & 0 & 0 \\
\hline 26.902888 & 21.653544 & 5.249344 & 16.0769 & 19.0298 & 0 & 0 \\
\hline 22.637796 & 17.716536 & 4.92126 & 14.1083 & 15.0926 & 0 & 0 \\
\hline 29.52756 & 23.622048 & 5.905512 & 16.405 & 15.7488 & 0 & 0 \\
\hline 28.871392 & 21.32546 & 7.545932 & 12.4678 & 17.7174 & 0 & 0 \\
\hline 45.275592 & 32.972442 & 12.30315 & 21.3265 & 20.9984 & 0 & 0 \\
\hline 41.83071 & 31.98819 & 9.84252 & 19.3579 & 17.7174 & 0 & 0 \\
\hline 29.52756 & 24.6063 & 4.92126 & 13.124 & 12.1397 & 0 & 0 \\
\hline 26.24672 & 22.96588 & 3.28084 & 19.0298 & 17.7174 & 0 & 0 \\
\hline 21.32546 & 18.04462 & 3.28084 & 13.124 & 12.1397 & 0 & 13 \\
\hline 31.824148 & 25.262468 & 6.56168 & 21.3265 & 28.5447 & 0 & 0 \\
\hline 18.700788 & 14.107612 & 4.593176 & 8.5306 & 9.1868 & 38 & 0 \\
\hline 19.028872 & 15.748032 & 3.28084 & 10.1711 & 15.0926 & 18 & 0 \\
\hline 15.748032 & 9.186352 & 6.56168 & 13.4521 & 10.1711 & 0 & 0 \\
\hline 28.215224 & 16.732284 & 11.48294 & 22.6389 & 18.7017 & 13 & 0 \\
\hline 22.637796 & 17.716536 & 4.92126 & 13.124 & 16.405 & 0 & 0 \\
\hline 13.12336 & 11.48294 & 1.64042 & 19.686 & 17.0612 & 0 & 0 \\
\hline 13.451444 & 9.186352 & 4.265092 & 14.4364 & 13.124 & 0 & 0 \\
\hline 31.824148 & 27.230972 & 4.593176 & 13.7802 & 13.124 & 0 & 0 \\
\hline 19.028872 & 12.139108 & 6.889764 & 10.4992 & 11.4835 & 0 & 0 \\
\hline 32.152232 & 20.341208 & 11.811024 & 14.7645 & 14.1083 & 0 & 0 \\
\hline 21.981628 & 15.748032 & 6.233596 & 11.8116 & 13.7802 & 0 & 0 \\
\hline 23.950132 & 16.732284 & 7.217848 & 11.1554 & 17.7174 & 0 & 0 \\
\hline
\end{tabular}




\begin{tabular}{|c|c|c|c|c|c|c|c|}
\hline 400 & 07-Jul-12 & -79.44962956 & 43.67188309 & 751,752 & ALEX1 & $\begin{array}{r}3.9370 \\
1\end{array}$ & \\
\hline & & & & & & 4.3307 & \\
\hline 401 & 07-Jul-12 & -79.44963423 & 43.67185456 & 753,754 & GYDI & 11 & \\
\hline 402 & 07-Jul-12 & -79.44962271 & 43.67184297 & 755,756 & ACFR & $\begin{array}{r}5.1181 \\
13\end{array}$ & \\
\hline & & & & & & 3.1496 & \\
\hline 403 & 07-Jul-12 & -79.44960919 & 43.67183278 & 757,758 & ALEX1 & 08 & \\
\hline 404 & 07-Jul-12 & -79.44959182 & 43.67181897 & 759,760 & ACSA2 & $\begin{array}{r}2.5590 \\
565 \\
50055\end{array}$ & \\
\hline 405 & 07-Jul-12 & -79.44957526 & 43.67181231 & 761,762 & ACFR & $\begin{array}{r}5.9055 \\
15\end{array}$ & \\
\hline & & & 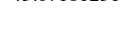 & (1) & & 3.9370 & \\
\hline 406 & 07-Jul-12 & -79.44955053 & 43.67170191 & 763,764 & QUMA1 & 1 & \\
\hline 407 & 07-Jul-12 & -79.44959518 & 43.67180329 & 765,766 & QURU & 1 & \\
\hline 408 & 07-Jul-12 & -79.44956596 & 43.67159992 & 767768 & AIAL & $\begin{array}{r}5.1181 \\
13 \\
4.3307\end{array}$ & \\
\hline 409 & 07-Jul-12 & -79.44953331 & 43.67160591 & 769,770 & QURU & 11 & \\
\hline 410 & 07-Jul-12 & -79.44954763 & 43.67162326 & 771,772 & ACFR & $\begin{array}{r}3.1496 \\
08 \\
5.433\end{array}$ & \\
\hline 411 & 07-Jul-12 & -79.44949725 & 43.67162972 & 773,774 & ACFR & 09 & \\
\hline & & & & 775, 776, & & 5.9055 & \\
\hline 412 & 07-Jul-12 & -79.44948336 & 43.67163382 & & ACFR & 15 & \\
\hline 413 & 07-Jul-12 & -79.44945369 & 43.67163914 & $\begin{array}{l}778,779, \\
780 \\
781,782,\end{array}$ & ALEX1 & $\begin{array}{r}2.3622 \\
06 \\
06\end{array}$ & \\
\hline 414 & 07-Jul-12 & -79.44945335 & 43.67161412 & 783 & ACFR & 07 & \\
\hline 415 & 07-Jul-12 & -79.44944989 & 43.67167196 & 784,785 & $\mathrm{ACNE}$ & 06 & \\
\hline 416 & 07-Jul-12 & -79.44940061 & 43.67163556 & 786,787 & PIST & $\begin{array}{r}13 \\
2.3622\end{array}$ & \\
\hline 417 & 07-Jul-12 & -79.44939625 & 43.67165194 & 786,787 & $\mathrm{ACPL}$ & 06 & \\
\hline 418 & 07-Jul-12 & -79.44940073 & 43.67166915 & 788,789 & PIST & $\begin{array}{r}.1181 \\
13 \\
5.9055\end{array}$ & \\
\hline 419 & 07-Jul-12 & -79.44940101 & 43.67169631 & 788,789 & ACNE & $\begin{array}{r}15 \\
35433\end{array}$ & \\
\hline 420 & 07-Jul-12 & -79.44948092 & 43.67169025 & 790,791 & PIST & & \\
\hline 421 & 07-Jul-12 & -79.4494746 & 43.67174448 & 792,793 & QURU & $\begin{array}{r}4.3307 \\
11 \\
11\end{array}$ & $\begin{array}{r}2.3622 \\
06\end{array}$ \\
\hline 422 & 07-Jul-12 & -79.44944329 & 43.67173691 & 794,795 & QURU & $\begin{array}{r}3.9370 \\
1\end{array}$ & \\
\hline 423 & 07-Jul-12 & -79.44951832 & 43.67176723 & 796,797 & GYDI & $\begin{array}{r}3.5433 \\
09 \\
9.4488\end{array}$ & \\
\hline 424 & 07-Jul-12 & -79.45379011 & 43.67413524 & 798,799 & ULGL & $\begin{array}{r}24 \\
3.5433\end{array}$ & \\
\hline 425 & 07-Jul-12 & -79.45375566 & 43.67411113 & 800,801 & ACFR & $\begin{array}{r}09 \\
27559\end{array}$ & \\
\hline 426 & 07-Jul-12 & -79.45368585 & 43.67404928 & 802,803 & ACFR & $\begin{array}{r}07 \\
3.5433\end{array}$ & \\
\hline 427 & 07-Jul-12 & -79.45366749 & 43.67403267 & 804,805 & QUMA1 & $\begin{array}{r}09 \\
5433\end{array}$ & \\
\hline $428-2$ & 07-Jul-12 & -79.45364779 & 43.67401968 & 806,807 & QURU & $\begin{array}{r}09 \\
3.5433\end{array}$ & \\
\hline 429 & 07-Jul-12 & -79.45362709 & 43.67399667 & 808,809 & ACFR & 09 & \\
\hline
\end{tabular}

\begin{tabular}{|c|c|c|c|c|c|c|}
\hline 24.278216 & 17.716536 & 6.56168 & 13.7802 & 11.8116 & 0 & 0 \\
\hline 25.590552 & 18.372704 & 7.217848 & 13.4521 & 13.124 & 0 & 0 \\
\hline 32.480316 & 27.559056 & 4.92126 & 15.7488 & 12.7959 & 13 & 0 \\
\hline 26.902888 & 18.04462 & 8.858268 & 9.5149 & 10.8273 & 0 & 0 \\
\hline 20.997376 & 13.451444 & 7.545932 & 7.5463 & 11.1554 & 0 & 0 \\
\hline 42.65092 & 34.776904 & 7.874016 & 14.1083 & 13.124 & 0 & 0 \\
\hline 18.372704 & 13.779528 & 4.593176 & 11.8116 & 11.8116 & 0 & 0 \\
\hline 18.700788 & 14.435696 & 4.265092 & 13.124 & 13.124 & 0 & 0 \\
\hline 21.653544 & 20.669292 & 0.984252 & 19.686 & 22.967 & 0 & 0 \\
\hline 16.076116 & 13.779528 & 2.296588 & 6.8901 & 10.8273 & 0 & 0 \\
\hline 17.388452 & 14.435696 & 2.952756 & 13.124 & 13.124 & 3 & 0 \\
\hline 25.262468 & 21.981628 & 3.28084 & 9.843 & 13.124 & 0 & 0 \\
\hline 33.464568 & 27.559056 & 5.905512 & 13.124 & 16.405 & 23 & 0 \\
\hline 8.530184 & 4.92126 & 3.608924 & 9.843 & 9.843 & 0 & 0 \\
\hline 17.388452 & 15.091864 & 2.296588 & 9.843 & 7.8744 & 28 & 0 \\
\hline 15.419948 & 12.139108 & 3.28084 & 9.843 & 5.9058 & 13 & 0 \\
\hline 21.653544 & 18.700788 & 2.952756 & 14.1083 & 13.7802 & 18 & 0 \\
\hline 21.653544 & 18.700788 & 2.952756 & 6.562 & 4.9215 & 18 & 0 \\
\hline 19.028872 & 15.748032 & 3.28084 & 14.4364 & 14.7645 & 8 & 0 \\
\hline 24.278216 & 23.293964 & 0.984252 & 17.3893 & 18.7017 & 8 & 0 \\
\hline 20.669292 & 16.732284 & 3.937008 & 11.1554 & 13.4521 & 0 & 0 \\
\hline 19.028872 & 17.388452 & 1.64042 & 17.3893 & 17.7174 & 0 & 0 \\
\hline 16.076116 & 10.826772 & 5.249344 & 19.3579 & 13.7802 & 0 & 18 \\
\hline 21.32546 & 11.154856 & 10.170604 & 9.5149 & 12.1397 & 0 & 8 \\
\hline 23.293964 & 22.96588 & 0.328084 & 22.3108 & 19.3579 & 0 & 0 \\
\hline 12.467192 & 9.84252 & 2.624672 & 6.562 & 8.8587 & 0 & 38 \\
\hline 16.076116 & 13.451444 & 2.624672 & 7.8744 & 6.562 & 0 & 28 \\
\hline 15.091864 & 14.435696 & 0.656168 & 8.5306 & 9.5149 & 0 & 0 \\
\hline 15.091864 & 11.48294 & 3.608924 & 10.8273 & 12.7959 & 0 & 13 \\
\hline 16.4042 & 11.811024 & 4.593176 & 9.1868 & 8.2025 & 0 & 13 \\
\hline
\end{tabular}




\begin{tabular}{|c|c|c|c|c|c|c|c|c|}
\hline 430 & 07-Jul-12 & -79.45359363 & 43.67398258 & 810,811 & QURU & $\begin{array}{r}3.5433 \\
09\end{array}$ & & \\
\hline 431 & 07-Jul-12 & -79.4535842 & 43.67395972 & 812,813 & GYDI & $\begin{array}{r}3.5433 \\
09\end{array}$ & & \\
\hline & & & & & & 3.1496 & & \\
\hline 432 & 07-Jul-12 & -79.45347811 & 43.67389647 & 814,816 & ACFR & 08 & & \\
\hline 433 & 07-Jul-12 & -79.45338687 & 43.6737916 & 815,817 & PIST & $\begin{array}{r}5.5118 \\
14\end{array}$ & & \\
\hline 434 & 07-Jul-12 & -79.45342581 & 43.67383576 & 820,821 & PIST & $\begin{array}{r}4.3307 \\
11\end{array}$ & & \\
\hline 435 & 07-Jul-12 & -79.45339717 & 43.67378083 & 818,819 & $\mathrm{AM}$ & $\begin{array}{r}3.1496 \\
08\end{array}$ & $\begin{array}{r}1.5748 \\
04\end{array}$ & \\
\hline & (7) Jur-12 & 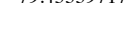 & 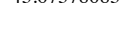 & , & & 2.3622 & 1.5748 & \\
\hline 436 & 07-Jul-12 & -79.45335358 & 43.67377115 & 818,819 & AM & $\begin{array}{r}06 \\
24015\end{array}$ & 04 & \\
\hline 437 & 07-Jul-12 & -79.45331605 & 43.67372064 & 822,823 & FRPE & $\begin{array}{r}761 \\
35433\end{array}$ & & \\
\hline 438 & 07-Jul-12 & -79.4532892 & 43.67369301 & 824,825 & QURU & 09 & & \\
\hline 439 & 07-Jul-12 & -79.4532353 & 43.67364591 & 826,827 & FRPE & $\begin{array}{r}3.1496 \\
08 \\
08\end{array}$ & $\begin{array}{r}2.7559 \\
07\end{array}$ & \\
\hline 440 & 07-Jul-12 & -79.45322813 & 43.67368127 & 828,830 & QURU & $\begin{array}{r}.5435 \\
09 \\
3.9370\end{array}$ & & \\
\hline 441 & 07-Jul-12 & -79.45318532 & 43.6736416 & 829,831 & GYDI & $\begin{array}{r}1 \\
3.5433\end{array}$ & & \\
\hline 442 & 07-Jul-12 & -79.45318609 & 43.67361161 & 832,833 & FRPE & $\begin{array}{r}09 \\
4.7244\end{array}$ & & \\
\hline 443 & 07-Jul-12 & -79.45316052 & 43.67358308 & 832,833 & ACFR & $\begin{array}{r}12 \\
5.1181\end{array}$ & & \\
\hline 444 & 07-Jul-12 & -79.45314658 & 43.67358926 & 834,836 & ACFR & 13 & & \\
\hline 445 & 09-Jul-12 & -79.45313672 & 43.67363185 & 835,837 & ACFR & $\begin{array}{r}3.5433 \\
09\end{array}$ & $\begin{array}{r}1.9685 \\
05\end{array}$ & $\begin{array}{r}1.9685 \\
05\end{array}$ \\
\hline 446 & 09-Jul-12 & -79.45312593 & 43.67356443 & 838,839 & ALEX1 & $\begin{array}{r}3.5433 \\
09 \\
3.1496\end{array}$ & & \\
\hline 447 & 09-Jul-12 & -79.45309345 & 43.67356127 & 840,841 & AM & $\begin{array}{r}08 \\
35433\end{array}$ & & \\
\hline 448 & 09-Jul-12 & -79.45311137 & 43.67354606 & 842,843 & FRPE & $\begin{array}{r}09 \\
2.7559\end{array}$ & & \\
\hline 449 & 09-Jul-12 & -79.45303936 & 43.67352144 & 844,845 & PIST & $\begin{array}{r}07 \\
3.1496\end{array}$ & & \\
\hline 450 & 09-Jul-12 & -79.45301562 & 43.6735193 & 846,847 & FRPE & $\begin{array}{r}08 \\
3.5433\end{array}$ & & \\
\hline 451 & 09-Jul-12 & -79.45307876 & 43.67349925 & 848,849 & ULGL & $\begin{array}{r}09 \\
2.7559\end{array}$ & & \\
\hline 452 & 09-Jul-12 & -79.4530772 & 43.67351105 & 850,851 & BEPA & $\begin{array}{r}07 \\
35433\end{array}$ & & \\
\hline 453 & 09-Jul-12 & -79.45309174 & 43.67348124 & 852,853 & PIST & $\begin{array}{r}09 \\
3.1496\end{array}$ & & \\
\hline 454 & 09-Jul-12 & -79.45303483 & 43.67345411 & $\begin{array}{l}854,855 \\
856,857\end{array}$ & PIST & $\begin{array}{r}08 \\
3.1496\end{array}$ & & \\
\hline 455 & 09-Jul-12 & -79.45300562 & 43.67342099 & 858 & FRPE & $\begin{array}{r}08 \\
3.1496\end{array}$ & & \\
\hline 456 & 09-Jul-12 & -79.45302882 & 43.67349312 & 859,860 & FRNI & $\begin{array}{r}08 \\
3.5433\end{array}$ & & \\
\hline 457 & 09-Jul-12 & -79.4529787 & 43.67344517 & 861 & FRPE & 09 & & \\
\hline 458 & 09-Jul-12 & -79.45294631 & 43.67343837 & 862 & ALEX1 & $\begin{array}{r}3.1496 \\
08 \\
3.1496\end{array}$ & & \\
\hline 459 & 09-Jul-12 & -79.45290217 & 43.67340141 & 863 & ACNE & 08 & & \\
\hline
\end{tabular}

\begin{tabular}{|c|c|c|c|c|}
\hline 16.4042 & 11.811024 & 4.593176 & 15.4207 & 13.7802 \\
\hline 21.653544 & 14.76378 & 6.889764 & 9.843 & 12.1397 \\
\hline 21.32546 & 13.779528 & 7.545932 & 13.124 & 9.843 \\
\hline 21.32546 & 17.060368 & 4.265092 & 13.7802 & 12.7959 \\
\hline 21.32546 & 17.060368 & 4.265092 & 9.843 & 11.4835 \\
\hline 22.637796 & 18.372704 & 4.265092 & 9.5149 & 10.8273 \\
\hline 22.637796 & 18.372704 & 4.265092 & 9.5149 & 10.8273 \\
\hline 14.76378 & 10.170604 & 4.593176 & 10.4992 & 9.5149 \\
\hline 14.435696 & 12.139108 & 2.296588 & 11.1554 & 9.843 \\
\hline 23.950132 & 21.32546 & 2.624672 & 15.0926 & 14.4364 \\
\hline 16.076116 & 13.779528 & 2.296588 & 11.4835 & 11.4835 \\
\hline 20.997376 & 15.748032 & 5.249344 & 12.7959 & 12.7959 \\
\hline 22.309712 & 17.716536 & 4.593176 & 9.5149 & 7.2182 \\
\hline 27.559056 & 24.934384 & 2.624672 & 12.4678 & 13.124 \\
\hline 26.902888 & 25.262468 & 1.64042 & 13.124 & 13.4521 \\
\hline 18.700788 & 16.076116 & 2.624672 & 10.8273 & 15.7488 \\
\hline 19.028872 & 16.4042 & 2.624672 & 10.4992 & 12.4678 \\
\hline 18.372704 & 17.060368 & 1.312336 & 11.8116 & 9.843 \\
\hline 20.997376 & 18.04462 & 2.952756 & 10.4992 & 11.8116 \\
\hline 11.811024 & 10.826772 & 0.984252 & 6.8901 & 6.2339 \\
\hline 15.419948 & 12.795276 & 2.624672 & 9.5149 & 9.843 \\
\hline 20.013124 & 16.732284 & 3.28084 & 12.1397 & 11.1554 \\
\hline 15.419948 & 13.12336 & 2.296588 & 9.843 & 9.1868 \\
\hline 11.811024 & 10.170604 & 1.64042 & 5.2496 & 5.5777 \\
\hline 10.498688 & 9.514436 & 0.984252 & 5.2496 & 6.562 \\
\hline 22.637796 & 20.341208 & 2.296588 & 9.1868 & 6.2339 \\
\hline 22.96588 & 19.68504 & 3.28084 & 7.8744 & 8.8587 \\
\hline 27.88714 & 22.96588 & 4.92126 & 8.8587 & 15.7488 \\
\hline 23.293964 & 17.388452 & 5.905512 & 13.124 & 12.1397 \\
\hline 16.732284 & 8.858268 & 7.874016 & 15.7488 & 8.8587 \\
\hline
\end{tabular}

\begin{tabular}{|c|c|}
\hline 0 & 23 \\
\hline 0 & 0 \\
\hline 0 & 0 \\
\hline 0 & 0 \\
\hline 0 & 0 \\
\hline 0 & 0 \\
\hline 0 & 0 \\
\hline 0 & 0 \\
\hline 0 & 0 \\
\hline 0 & 0 \\
\hline 13 & 13 \\
\hline 0 & 0 \\
\hline 0 & 0 \\
\hline 0 & 0 \\
\hline 8 & 0 \\
\hline 38 & 0 \\
\hline 0 & 0 \\
\hline 0 & 0 \\
\hline 0 & 0 \\
\hline 0 & 0 \\
\hline 0 & 0 \\
\hline 0 & 13 \\
\hline 0 & 0 \\
\hline 0 & 18 \\
\hline 0 & 13 \\
\hline 0 & 0 \\
\hline 0 & 0 \\
\hline 0 & 0 \\
\hline 0 & 0 \\
\hline 0 & 0 \\
\hline
\end{tabular}




\begin{tabular}{|c|c|c|c|c|c|c|c|}
\hline \multirow[t]{2}{*}{460} & 09-Jul-12 & -79.45295808 & 43.67337034 & 864,865 & TICO & $\begin{array}{r}3.1496 \\
08\end{array}$ & $\begin{array}{r}2.7559 \\
07\end{array}$ \\
\hline & & & & & & & \\
\hline \multirow[t]{2}{*}{461} & 09-Jul-12 & -79.45287809 & 43.67334889 & 866,867 & ACSA2 & 07 & \\
\hline & & & & & & 3.5433 & 3.1496 \\
\hline 462 & 09-Jul-12 & -79.45285287 & 43.67330483 & 868 & TIAM & 09 & 08 \\
\hline \multirow{2}{*}{463} & 09-Jul-12 & -79.45283075 & 43.67328678 & 868 & ACNE & 5.5118 & \\
\hline & & & & & & 4.3307 & \\
\hline \multirow[t]{2}{*}{464} & 09-Jul-12 & -79.45280274 & 43.6732782 & 869 & FRPE & 11 & \\
\hline & & & & & & 3.5433 & \\
\hline \multirow[t]{2}{*}{465} & 09-Jul-12 & -79.45281821 & 43.67326202 & 869 & FRPE & 09 & \\
\hline & & & & & & 5.5118 & \\
\hline \multirow{2}{*}{466} & 09-Jul-12 & -79.45275187 & 43.67328024 & 870 & JUNI & 14 & \\
\hline & & & & & & 2.3622 & \\
\hline \multirow{2}{*}{467} & 09-Jul-12 & -79.4528079 & 43.67322363 & 871 & QURU & 06 & \\
\hline & 09-Jul-12 & -79.45278547 & 43.67321786 & $\begin{array}{l}872,873, \\
874\end{array}$ & GYDI & $\begin{array}{r}3.5433 \\
09\end{array}$ & \\
\hline 468 & s & 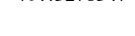 & 45.0752180 & 872, 873, & & 2.7559 & \\
\hline \multirow[t]{2}{*}{469} & 09-Jul-12 & -79.4527592 & 43.67321477 & & JUNI & 07 & \\
\hline & 09-Jul-1 & 79.4527014 & 43.6731 & 876 & $\mathrm{OU}$ & 3.1496 & \\
\hline 470 & s. & 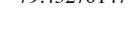 & 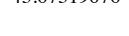 & 年 & porvo & 3.5433 & \\
\hline \multirow[t]{2}{*}{471} & 09-Jul-12 & -79.4527152 & 43.67316909 & 877,878 & QUMA1 & 09 & \\
\hline & 09-Jul- & 7045271106 & 4367314856 & 870 & PIST & 4.3307 & \\
\hline 472 & (0) & 0 & 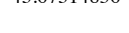 & (1) & PIST & 11 & \\
\hline \multirow[t]{2}{*}{473} & 09-Jul-12 & -79.45265636 & 43.67311502 & 880 & QURU & 08 & \\
\hline & & & & & & 6.2992 & \\
\hline \multirow[t]{2}{*}{474} & 09-Jul-12 & -79.45262612 & 43.67312007 & 881 & JUNI & 16 & \\
\hline & & & & & & 3.9370 & \\
\hline 475 & 09-Jul-12 & -79.45265749 & 43.67307132 & 882 & PIST & 1 & \\
\hline \multirow{2}{*}{476} & 09-Jul-12 & -79.45264038 & 43.67307792 & 884 & JUNI & $\begin{array}{r}2.3622 \\
06\end{array}$ & \\
\hline & & 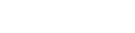 & 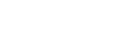 & 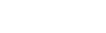 & . & 4.7244 & \\
\hline \multirow{2}{*}{477} & 09-Jul-12 & -79.45264687 & 43.67307246 & 885 & ACSA1 & 12 & 06 \\
\hline & & & & & & 3.1496 & \\
\hline \multirow[t]{2}{*}{478} & 09-Jul-12 & -79.45263572 & 43.6730345 & 886 & TICO & & \\
\hline & & & & & & 4.3307 & \\
\hline 479 & 09-Jul-12 & -79.4526065 & 43.67302589 & 888 & ТICO & 11 & \\
\hline 480 & 09-Jul-12 & -79.45257489 & 43.67302217 & 889,890 & PIST & $\begin{array}{r}7.8740 \\
2\end{array}$ & \\
\hline & & & & & & 3.9370 & \\
\hline 481 & 09-Jul-12 & -79.45253281 & 43.67298544 & 892,893 & JUNI & 1 & \\
\hline 482 & 09-Jul-12 & -79.45250405 & 43.67295875 & 894 & ALEX1 & $\begin{array}{r}3.9370 \\
1\end{array}$ & \\
\hline & & & & & & 4.7244 & \\
\hline 483 & 09-Jul-12 & -79.45245782 & 43.67290717 & 895 & ALEX1 & 12 & \\
\hline & & & & & & 3.5433 & \\
\hline 484 & 09-Jul-12 & -79.4523444 & 43.67282674 & 896 & ALEXI & 09 & \\
\hline 485 & 09-Jul-12 & -79.45238963 & 43.672829 & 897 & JUNI & $\begin{array}{r}. .1539 \\
07\end{array}$ & \\
\hline & & the & & & & 3.9370 & \\
\hline 486 & 09-Jul-12 & -79.45234315 & 43.67278727 & 898 & ACSA1 & 1 & \\
\hline & & & & & & 2.3622 & \\
\hline 487 & 09-Jul- & -79.45224082 & 43.67280397 & 900,901 & ACNE & 06 & \\
\hline 488 & 09-Jul-12 & -7945229897 & 43.67274394 & & & 3.9370 & \\
\hline (700 & O9-Juा-12 & -19.4529091 & 43.01274394 & 800, & ACNDE & 2.7559 & \\
\hline 489 & 09-Jul-12 & -79.4522566 & 43.67271871 & 899 & TICO & 07 & \\
\hline
\end{tabular}

\begin{tabular}{|c|c|c|c|c|}
\hline 16.732284 & 14.107612 & 2.624672 & 9.1868 & 10.1711 \\
\hline 17.060368 & 14.76378 & 2.296588 & 10.4992 & 9.5149 \\
\hline 22.96588 & 22.309712 & 0.656168 & 9.843 & 13.124 \\
\hline 22.96588 & 22.309712 & 0.656168 & 14.1083 & 16.0769 \\
\hline 24.6063 & 24.6063 & 0 & 11.1554 & 16.405 \\
\hline 24.6063 & 24.6063 & 0 & 11.1554 & 16.405 \\
\hline 32.152232 & 27.559056 & 4.593176 & 17.0612 & 16.0769 \\
\hline 21.653544 & 17.060368 & 4.593176 & 10.1711 & 10.4992 \\
\hline 21.32546 & 13.12336 & 8.2021 & 13.7802 & 12.7959 \\
\hline 13.12336 & 8.858268 & 4.265092 & 11.1554 & 9.843 \\
\hline 15.419948 & 14.435696 & 0.984252 & 10.8273 & 9.1868 \\
\hline 22.309712 & 21.653544 & 0.656168 & 8.2025 & 11.1554 \\
\hline 17.060368 & 15.748032 & 1.312336 & 14.4364 & 10.8273 \\
\hline 20.997376 & 17.060368 & 3.937008 & 10.8273 & 14.1083 \\
\hline 41.666668 & 37.073492 & 4.593176 & 20.3422 & 21.3265 \\
\hline 20.341208 & 17.388452 & 2.952756 & 8.8587 & 7.2182 \\
\hline 15.091864 & 13.451444 & 1.64042 & 9.843 & 11.1554 \\
\hline 22.309712 & 21.32546 & 0.984252 & 18.7017 & 14.1083 \\
\hline 19.356956 & 13.12336 & 6.233596 & 9.1868 & 9.5149 \\
\hline 20.669292 & 16.076116 & 4.593176 & 9.843 & 10.8273 \\
\hline 27.88714 & 25.918636 & 1.968504 & 16.0769 & 14.7645 \\
\hline 25.918636 & 17.388452 & 8.530184 & 15.7488 & 17.3893 \\
\hline 22.96588 & 16.732284 & 6.233596 & 10.1711 & 13.7802 \\
\hline 35.104988 & 30.511812 & 4.593176 & 16.405 & 15.7488 \\
\hline 27.230972 & 20.997376 & 6.233596 & 12.1397 & 11.8116 \\
\hline 21.32546 & 14.76378 & 6.56168 & 5.9058 & 12.4678 \\
\hline 30.511812 & 23.950132 & 6.56168 & 8.8587 & 9.5149 \\
\hline 14.76378 & 7.545932 & 7.217848 & 13.4521 & 8.2025 \\
\hline 20.997376 & 13.779528 & 7.217848 & 15.4207 & 9.843 \\
\hline 24.278216 & 13.779528 & 10.498688 & 10.4992 & 7.5463 \\
\hline
\end{tabular}

\begin{tabular}{|c|c|}
\hline 18 & 3 \\
\hline 0 & 0 \\
\hline 0 & 0 \\
\hline 0 & 0 \\
\hline 0 & 0 \\
\hline 0 & 0 \\
\hline 0 & 0 \\
\hline 0 & 0 \\
\hline 0 & 0 \\
\hline 13 & 0 \\
\hline 0 & 0 \\
\hline 0 & 0 \\
\hline 28 & 0 \\
\hline 13 & 0 \\
\hline 0 & 0 \\
\hline 8 & 0 \\
\hline 0 & 0 \\
\hline 0 & 0 \\
\hline 0 & 0 \\
\hline 13 & 0 \\
\hline 0 & 0 \\
\hline 0 & 0 \\
\hline 13 & 0 \\
\hline 13 & 0 \\
\hline 23 & 0 \\
\hline 23 & 0 \\
\hline 13 & 0 \\
\hline 33 & 0 \\
\hline 33 & 0 \\
\hline 18 & 0 \\
\hline
\end{tabular}




\begin{tabular}{|c|c|c|c|c|c|c|c|c|}
\hline 490 & 09-Jul-12 & -79.45224595 & 43.67269227 & 902,903 & FRPE & $\begin{array}{r}5.5118 \\
14\end{array}$ & & \\
\hline & & & & & & 3.1496 & & \\
\hline \multirow[t]{2}{*}{491} & 09-Jul-12 & -79.45220605 & 43.67265885 & 904 & AIAL & 08 & & \\
\hline & & & & & & 5.9055 & & \\
\hline \multirow[t]{2}{*}{492} & 09-Jul-12 & -79.45217537 & 43.67261899 & 905,906 & AIAL & 15 & & \\
\hline & & & & & & 3.1496 & & \\
\hline \multirow[t]{2}{*}{493} & 09-Jul-12 & -79.45215119 & 43.67259072 & 907 & AIAL & 08 & & \\
\hline & & & & & & 3.9370 & & \\
\hline 494 & (y-jul-12 & -19.45211279 & $43.6 / 258691$ & 908,909 & FRPE & $\begin{array}{r}1 \\
5.5118\end{array}$ & & \\
\hline 495 & 12-Jul-12 & -79.45210394 & 43.67257616 & 910,911 & ACNE & 14 & & \\
\hline \multirow[t]{2}{*}{496} & 12-Jul-12 & -79.45210009 & 43.67257268 & 912,913 & AIAL & $\begin{array}{r}3.5433 \\
09\end{array}$ & & \\
\hline & & & & & & 3.5433 & & \\
\hline 497 & 12-Jul-12 & -79.45203089 & 43.67251348 & 914,915 & JUNI & 09 & & \\
\hline \multirow[t]{2}{*}{498} & 12-Jul-12 & -79.45206338 & 43.67248269 & 916,917 & FRNI & $\begin{array}{r}3.5433 \\
09\end{array}$ & & \\
\hline & & & & & & 5.1181 & & \\
\hline 499 & 12-Jul-12 & -79.45203903 & 43.67246099 & 918,919 & FRPE & 13 & & \\
\hline \multirow[t]{2}{*}{501} & 12-Jul-12 & -79.45193953 & 43.67236759 & 922,923 & QURU & $\begin{array}{r}2.7559 \\
07\end{array}$ & & \\
\hline & & & & 924,925, & & 4.7244 & & \\
\hline \multirow[t]{2}{*}{502} & 12-Jul-12 & -79.45190855 & 43.67233923 & & PIST & 12 & & \\
\hline & & & & & & 3.5433 & & \\
\hline \multirow{2}{*}{503} & 12-Jul-12 & -79.45188185 & 43.67232079 & 927 & PIST & 09 & & \\
\hline & & & & & & 2.4803 & & \\
\hline \multirow[t]{2}{*}{504} & 12-Jul-12 & -79.45186891 & 43.67229596 & 928 & JUNI & 163 & & \\
\hline & & & & & & 3.1496 & & \\
\hline \multirow{2}{*}{505} & 12-Jul-12 & -79.45181961 & 43.67227556 & 929 & FRPE & 08 & & \\
\hline & & & & & & 4.3307 & 4.3307 & 3.9370 \\
\hline \multirow{2}{*}{506} & 12-Jul-12 & -79.45182976 & 43.67223296 & 930,931 & ACNE & 11 & 11 & \\
\hline & & & & 932,933, & & 5.9055 & 5.5118 & 4.3307 \\
\hline 507 & 12-Jul-12 & -79.45177821 & 43.67221254 & 934 & ACNE & 15 & 14 & 11 \\
\hline \multirow[t]{2}{*}{508} & 12-Jul-12 & -79.45167043 & 43.67217656 & 936,937 & FRPE & $\begin{array}{r}5.5118 \\
14\end{array}$ & & \\
\hline & & & & & & 3.1496 & & \\
\hline \multirow[t]{2}{*}{509} & 12-Jul-12 & -79.45160153 & 43.67212632 & 938,939 & JUNI & 08 & & \\
\hline & & & & 940, 941, & & 3.1496 & & \\
\hline \multirow[t]{2}{*}{510} & 12-Jul-12 & -79.45166861 & 43.67207134 & & QURU & 08 & & \\
\hline & & & & 943,944 & & 3.9370 & & \\
\hline 511 & 12-Jul-12 & -79.45163243 & 43.67206921 & 945 & PIST & 1 & & \\
\hline 512 & 12-Jul-12 & -79.45160472 & 43.6720902 & 946,947 & ALEX1 & 5.1181 & & \\
\hline & & 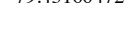 & 43.0720902 & 940,941 & ALEX1 & $\begin{array}{r}13 \\
51181\end{array}$ & & \\
\hline 513 & 12-Jul-12 & -79.45153072 & 43.67215002 & 948,949 & ALEX1 & 13 & & \\
\hline & & & & 950,951, & & 7.4803 & & \\
\hline 514 & 12-Jul-12 & -79.45154565 & 43.67209762 & 952 & JUNI & 19 & & \\
\hline 515 & 12 Jul 12 & $45150 \mathrm{0}>\mathrm{s}$ & 71070 & & TICO & 3.9370 & & \\
\hline & 12-Ju1-1L & 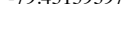 & 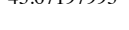 & 955.956 & 1100 & 1 & & \\
\hline 516 & 12-Jul-12 & -79.45156509 & 43.67195817 & 957 & QUMA1 & $\begin{array}{r}.5 .353 \\
09\end{array}$ & & \\
\hline & & & & & & 2.5590 & & \\
\hline 517 & 12-Jul-12 & -79.45153549 & 43.67196434 & 958,959 & QUMA1 & 565 & & \\
\hline & & & & 961, 962, & & 3.5433 & & \\
\hline 510 & $12-\mathrm{Jul}-12$ & -19.43133498 & $43.0 / 198400$ & & JUNI & (9) & & \\
\hline 519 & 12-Jul-12 & -79.45147618 & 43.67198306 & 964 & PIST & 1 & & \\
\hline & $12-\mathrm{Jul}-12$ & 9511 & 43.67202316 & 963 & & 3.9370 & & \\
\hline
\end{tabular}

\begin{tabular}{|c|c|c|c|c|}
\hline 26.574804 & 21.653544 & 4.92126 & 16.405 & 12.4678 \\
\hline 15.091864 & 12.139108 & 2.952756 & 10.4992 & 13.124 \\
\hline 15.748032 & 8.858268 & 6.889764 & 16.0769 & 15.7488 \\
\hline 15.748032 & 8.2021 & 7.545932 & 17.7174 & 19.686 \\
\hline 27.88714 & 14.76378 & 13.12336 & 11.4835 & 10.4992 \\
\hline 34.44882 & 29.199476 & 5.249344 & 9.843 & 16.7331 \\
\hline 15.748032 & 11.811024 & 3.937008 & 14.4364 & 7.8744 \\
\hline 25.590552 & 15.091864 & 10.498688 & 10.1711 & 5.9058 \\
\hline 23.622048 & 12.795276 & 10.826772 & 10.8273 & 10.4992 \\
\hline 31.496064 & 22.96588 & 8.530184 & 13.124 & 18.0455 \\
\hline 23.293964 & 19.68504 & 3.608924 & 10.8273 & 10.8273 \\
\hline 17.388452 & 14.107612 & 3.28084 & 9.5149 & 10.8273 \\
\hline 13.451444 & 11.154856 & 2.296588 & 7.5463 & 9.1868 \\
\hline 20.341208 & 13.12336 & 7.217848 & 7.5463 & 10.4992 \\
\hline 22.637796 & 15.748032 & 6.889764 & 8.2025 & 6.562 \\
\hline 28.543308 & 24.6063 & 3.937008 & 20.3422 & 20.3422 \\
\hline 37.401576 & 28.215224 & 9.186352 & 17.7174 & 28.5447 \\
\hline 22.637796 & 17.388452 & 5.249344 & 12.1397 & 12.7959 \\
\hline 24.6063 & 15.419948 & 9.186352 & 11.8116 & 20.0141 \\
\hline 20.341208 & 14.76378 & 5.577428 & 11.4835 & 11.4835 \\
\hline 17.060368 & 13.779528 & 3.28084 & 13.124 & 14.7645 \\
\hline 29.855644 & 22.637796 & 7.217848 & 11.1554 & 13.124 \\
\hline 29.52756 & 25.918636 & 3.608924 & 10.4992 & 14.4364 \\
\hline 26.902888 & 20.997376 & 5.905512 & 19.3579 & 19.0298 \\
\hline 17.716536 & 11.48294 & 6.233596 & 10.8273 & 11.8116 \\
\hline 18.372704 & 17.060368 & 1.312336 & 12.1397 & 12.7959 \\
\hline 19.356956 & 15.748032 & 3.608924 & 6.562 & 10.8273 \\
\hline 19.68504 & 12.139108 & 7.545932 & 11.8116 & 11.1554 \\
\hline 16.732284 & 10.826772 & 5.905512 & 6.8901 & 9.1868 \\
\hline 25.918636 & 17.716536 & 8.2021 & 13.124 & 10.4992 \\
\hline
\end{tabular}

\begin{tabular}{|c|c|}
\hline 13 & 0 \\
\hline 23 & 13 \\
\hline 23 & 0 \\
\hline 23 & 0 \\
\hline 18 & 0 \\
\hline 0 & 0 \\
\hline 0 & 0 \\
\hline 0 & 0 \\
\hline 13 & 0 \\
\hline 8 & 0 \\
\hline 0 & 0 \\
\hline 33 & 0 \\
\hline 23 & 0 \\
\hline 13 & 0 \\
\hline 33 & 0 \\
\hline 23 & 0 \\
\hline 8 & 0 \\
\hline 13 & 0 \\
\hline 13 & 0 \\
\hline 0 & 0 \\
\hline 0 & 0 \\
\hline 0 & 0 \\
\hline 0 & 0 \\
\hline 0 & 0 \\
\hline 0 & 0 \\
\hline 0 & 0 \\
\hline 0 & 0 \\
\hline 0 & 0 \\
\hline 0 & 0 \\
\hline 0 & 0 \\
\hline
\end{tabular}




\begin{tabular}{|c|c|c|c|c|c|c|}
\hline 521 & 12-Jul-12 & -79.45146371 & 43.67201549 & $\begin{array}{l}966,967, \\
968\end{array}$ & TICO & $\begin{array}{r}3.9370 \\
1 \\
2.5590\end{array}$ \\
\hline 522 & 12-Jul-12 & -79.45143468 & 43.67198009 & 969,970 & JUNI & $\begin{array}{r}565 \\
3.496\end{array}$ \\
\hline 523 & 12-Jul-12 & -79.45143311 & 43.67197644 & 971,972 & PIST & $\begin{array}{r}08 \\
3.9370\end{array}$ \\
\hline 524 & 12-Jul-12 & -79.45145864 & 43.67195385 & 973,974 & TICO & $\begin{array}{r}1 \\
4.3307\end{array}$ \\
\hline 525 & 12-Jul-12 & -79.45145864 & 43.67195385 & $\begin{array}{l}975,976 \\
1009,\end{array}$ & TICO & $\begin{array}{r}11 \\
22.440\end{array}$ \\
\hline 526 & 12-Jul-12 & -79.45148232 & 43.67193848 & $\begin{array}{l}1010 \\
1011 .\end{array}$ & JUNI & $\begin{array}{r}957 \\
2.7559\end{array}$ \\
\hline 527 & 12-Jul-12 & -79.45151077 & 43.67193162 & $\begin{array}{l}1012 \\
1013,\end{array}$ & ACNE & $\begin{array}{r}07 \\
3.1496\end{array}$ \\
\hline 528 & 16-Jul-12 & -79.45155656 & 43.67189723 & 1014 & ACNE & $\begin{array}{r}08 \\
5.5118\end{array}$ \\
\hline 529 & 16-Jul-12 & -79.45155198 & 43.67188147 & 1016, & ALEX1 & $\begin{array}{r}14 \\
3.9370\end{array}$ \\
\hline 530 & 16-Jul-12 & -79.45151263 & 43.67185921 & $\begin{array}{l}1017 \\
1018, \\
1019,\end{array}$ & FRPE & $\begin{array}{r}1 \\
2.7559\end{array}$ \\
\hline 531 & 16-Jul-12 & -79.45148674 & 43.67183109 & 1020 & QUBI & $\begin{array}{r}07 \\
3.9370\end{array}$ \\
\hline 532 & 16-Jul-12 & -79.45145363 & 43.6718898 & 1023 & FRPE & $\begin{array}{r}1 \\
3.5433\end{array}$ \\
\hline 533 & 16-Jul-12 & -79.45144594 & 43.67186555 & $\begin{array}{l}1024 \\
1025\end{array}$ & FRPE & $\begin{array}{r}09 \\
3.9370\end{array}$ \\
\hline 534 & 16-Jul-12 & -79.45141486 & 43.6719098 & $\begin{array}{l}1026 \\
1027,\end{array}$ & $\mathrm{ACNE}$ & $\begin{array}{r}1 \\
3.1496\end{array}$ \\
\hline 535 & 16-Jul-12 & -79.45138293 & 43.67192264 & $\begin{array}{l}1028 \\
1029 .\end{array}$ & FRPE & $\begin{array}{r}08 \\
3.1496\end{array}$ \\
\hline 536 & 16-Jul-12 & -79.45135131 & 43.67192342 & $\begin{array}{l}1030 \\
1031,\end{array}$ & CASP & $\begin{array}{r}08 \\
2.3622\end{array}$ \\
\hline 537 & 16-Jul-12 & -79.45135131 & 43.67192342 & $\begin{array}{l}1032 \\
1033,\end{array}$ & CASP & $\begin{array}{r}06 \\
4.3307\end{array}$ \\
\hline 538 & 16-Jul-12 & -79.45136191 & 43.67189942 & 1034 & QUBI & $\begin{array}{r}11 \\
3.5433\end{array}$ \\
\hline 539 & 16-Jul-12 & -79.45139945 & 43.6718625 & 1036, & ACNE & $\begin{array}{r}09 \\
9.8425\end{array}$ \\
\hline 540 & 16-Jul-12 & -79.45139915 & 43.67180938 & $\begin{array}{l}1037 \\
1038 \\
1039,104\end{array}$ & PIRE & $\begin{array}{r}25 \\
27.952\end{array}$ \\
\hline 541 & 16-Jul-12 & -79.45138702 & 43.67182853 & $\begin{array}{l}0 \\
1041,\end{array}$ & JUNI & $\begin{array}{r}771 \\
11.417\end{array}$ \\
\hline 542 & 16-Jul-12 & -79.45136981 & 43.67178604 & $\begin{array}{l}1042 \\
1049,\end{array}$ & PIRE & $\begin{array}{r}329 \\
19.291\end{array}$ \\
\hline 543 & 16-Jul-12 & -79.45136218 & 43.67175938 & $\begin{array}{l}1050 \\
1051\end{array}$ & FRPE & $\begin{array}{r}349 \\
14566\end{array}$ \\
\hline 544 & 16-Jul-12 & -79.45133678 & 43.67177714 & $\begin{array}{l}1052 \\
1053,\end{array}$ & PINI & $\begin{array}{r}937 \\
14.960\end{array}$ \\
\hline 545 & 16-Jul-12 & -79.45132234 & 43.67175643 & $\begin{array}{l}1054 \\
1055\end{array}$ & PINI & $\begin{array}{r}638 \\
13.779\end{array}$ \\
\hline 546 & 16-Jul-12 & -79.45130094 & 43.67174768 & $\begin{array}{l}1056 \\
1057\end{array}$ & PINI & $\begin{array}{r}535 \\
12.992\end{array}$ \\
\hline 547 & 16-Jul-12 & -79.45130811 & 43.67179245 & $\begin{array}{l}1058 \\
1059\end{array}$ & PINI & $\begin{array}{r}133 \\
11.023\end{array}$ \\
\hline 548 & 16-Jul-12 & -79.45130811 & 43.67179245 & $\begin{array}{l}1060 \\
1061,\end{array}$ & PINI & $\begin{array}{r}628 \\
24.015\end{array}$ \\
\hline 54 & 16-Jul-12 & -79.45129136 & 43.67179 & 1062 & FRNI & 761 \\
\hline
\end{tabular}

\begin{tabular}{|c|c|c|c|c|c|c|}
\hline 20.669292 & 18.04462 & 2.624672 & 8.8587 & 13.4521 & 0 & 0 \\
\hline 19.028872 & 14.826572 & 4.2023 & 10.8273 & 6.8901 & 0 & 0 \\
\hline 15.419948 & 10.170604 & 5.249344 & 9.843 & 8.5306 & 0 & 0 \\
\hline 18.04462 & 14.76378 & 3.28084 & 16.405 & 10.4992 & 0 & 0 \\
\hline 11.811024 & 10.498688 & 1.312336 & 12.7959 & 16.0769 & 0 & 0 \\
\hline 72.17848 & 60.367456 & 11.811024 & 51.5117 & 43.6373 & 0 & 0 \\
\hline 11.811024 & 11.811024 & 0 & 13.4521 & 10.8273 & 8 & 0 \\
\hline 20.013124 & 20.013124 & 0 & 13.124 & 13.124 & 0 & 0 \\
\hline 20.341208 & 11.48294 & 8.858268 & 13.7802 & 11.8116 & 23 & 0 \\
\hline 26.902888 & 20.669292 & 6.233596 & 15.0926 & 14.7645 & 0 & 0 \\
\hline 18.04462 & 11.811024 & 6.233596 & 13.7802 & 11.1554 & 23 & 28 \\
\hline 31.003938 & 16.240158 & 14.76378 & 12.7959 & 11.8116 & 0 & 0 \\
\hline 35.433072 & 25.590552 & 9.84252 & 14.7645 & 12.7959 & 0 & 0 \\
\hline 34.44882 & 24.278216 & 10.170604 & 24.6075 & 16.405 & 0 & 0 \\
\hline 23.622048 & 21.653544 & 1.968504 & 12.7959 & 7.8744 & 33 & 0 \\
\hline 20.997376 & 16.4042 & 4.593176 & 11.8116 & 13.7802 & 0 & 18 \\
\hline 10.498688 & 5.905512 & 4.593176 & 14.1083 & 13.124 & 23 & 0 \\
\hline 27.06693 & 22.14567 & 4.92126 & 12.7959 & 12.1397 & 38 & 0 \\
\hline 22.309712 & 17.060368 & 5.249344 & 17.3893 & 14.7645 & 0 & 0 \\
\hline 33.464568 & 25.590552 & 7.874016 & 23.6232 & 24.2794 & 33 & 18 \\
\hline 63.15617 & 52.49344 & 10.66273 & 65.2919 & 80.3845 & 0 & 0 \\
\hline 42.322836 & 33.464568 & 8.858268 & 24.6075 & 20.3422 & 23 & 13 \\
\hline 64.79659 & 51.67323 & 13.12336 & 55.777 & 43.3092 & 8 & 0 \\
\hline 49.868768 & 35.433072 & 14.435696 & 26.248 & 27.8885 & 0 & 78 \\
\hline 52.49344 & 38.057744 & 14.435696 & 23.6232 & 34.4505 & 0 & 73 \\
\hline 43.963256 & 32.8084 & 11.154856 & 19.3579 & 24.2794 & 0 & 83 \\
\hline 40.682416 & 28.215224 & 12.467192 & 22.3108 & 20.6703 & 0 & 83 \\
\hline 49.868768 & 29.52756 & 20.341208 & 21.6546 & 19.3579 & 23 & 68 \\
\hline 47.900264 & 37.401576 & 10.498688 & 47.2464 & 43.9654 & 0 & 38 \\
\hline
\end{tabular}




\begin{tabular}{|c|c|c|c|c|c|c|}
\hline 550 & 16-Jul-12 & -79.45131238 & 43.67182028 & $\begin{array}{l}1063, \\
1064\end{array}$ & ALEX1 & $\begin{array}{r}2.7559 \\
07\end{array}$ \\
\hline 551 & 16-Jul-12 & -79.45131001 & 43.67184801 & $\begin{array}{l}1065, \\
1066\end{array}$ & BEAL & $\begin{array}{r}5.5118 \\
14\end{array}$ \\
\hline & & & & 1067, & & 2.3622 \\
\hline 552 & 16-Jul-12 & -79.45122479 & 43.67179857 & 1068 & ACPL & 06 \\
\hline 553 & 16-Jul-12 & -79.45126511 & 43.6718474 & $\begin{array}{l}1070, \\
1071\end{array}$ & ALEX1 & $\begin{array}{r}2.7559 \\
07\end{array}$ \\
\hline 554 & 16-Jul-12 & -79.45124249 & 43.67182174 & $\begin{array}{l}1072, \\
1073 \\
1074\end{array}$ & ALEX1 & $\begin{array}{r}2.7559 \\
07 \\
70866\end{array}$ \\
\hline 555 & 16-Jul-12 & -79.45122682 & 43.67178411 & 1075 & BEAL & 18 \\
\hline 556 & 16-Jul-12 & -79.45127708 & 43.6717703 & $\begin{array}{l}1074, \\
1075\end{array}$ & BEAL & $\begin{array}{r}5.5118 \\
14 \\
2.3622\end{array}$ \\
\hline 557 & 16-Jul-12 & -79.4511945 & 43.67174745 & 1076 & BEAL & $\begin{array}{r}06 \\
55118\end{array}$ \\
\hline 558 & 16-Jul-12 & -79.45125299 & 43.67167218 & 1077 & BEAL & $\begin{array}{r}14 \\
43307\end{array}$ \\
\hline 559 & 16-Jul-12 & -79.45123641 & 43.67173474 & 1078 & QUMA1 & $\begin{array}{r}11 \\
3.9370\end{array}$ \\
\hline 560 & 16-Jul-12 & -79.45125369 & 43.67170962 & 1080 & BEAL & $\begin{array}{r}1 \\
4.3307\end{array}$ \\
\hline 561 & 16-Jul-12 & -79.45130327 & 43.67165717 & 1081 & QUMA1 & $\begin{array}{r}11 \\
2.5196\end{array}$ \\
\hline 562 & 16-Jul-12 & -79.45129928 & 43.67161848 & 1082 & ALEX1 & 864 \\
\hline 563 & 16-Jul-12 & -79.4512065 & 43.67166914 & 1083 & FRNI & $\begin{array}{r}2.7559 \\
07 \\
31496\end{array}$ \\
\hline 564 & 16-Jul-12 & -79.45121099 & 43.67168852 & $\begin{array}{l}1085 \\
1086\end{array}$ & FRNI & $\begin{array}{r}08 \\
08 \\
16.141\end{array}$ \\
\hline 565 & 16-Jul-12 & -79.45118219 & 43.67170865 & 1087 & CASP & $\begin{array}{r}741 \\
24015\end{array}$ \\
\hline 566 & 16-Jul-12 & -79.45114847 & 43.6717263 & 1089 & BEAL & $\begin{array}{r}761 \\
29527\end{array}$ \\
\hline 567 & 16-Jul-12 & -79.45114263 & 43.67169483 & $\begin{array}{l}1091 \\
1092,\end{array}$ & FRPE & 575 \\
\hline 568 & 16-Jul-12 & -79.45114987 & 43.67167199 & $\begin{array}{l}1093, \\
1094 \\
1092,109\end{array}$ & BEAL & $\begin{array}{r}3.5433 \\
09 \\
4.7244\end{array}$ \\
\hline 569 & 16-Jul-12 & -79.45114193 & 43.6716574 & $\begin{array}{l}3,1094 \\
1095\end{array}$ & BEAL & $\begin{array}{r}12 \\
24.015\end{array}$ \\
\hline 570 & 16-Jul-12 & -79.45113059 & 43.67165474 & 1096 & ACPL & $\begin{array}{r}761 \\
16141\end{array}$ \\
\hline 571 & 21-Jul-12 & -79.45111375 & 43.6716688 & $\begin{array}{l}1098 \\
1099\end{array}$ & CASP & $\begin{array}{r}741 \\
20.078\end{array}$ \\
\hline 572 & 21-Jul-12 & -79.45109061 & 43.67164825 & $\begin{array}{l}1100 \\
1132\end{array}$ & ACSA1 & $\begin{array}{r}751 \\
24409\end{array}$ \\
\hline 573 & 21-Jul-12 & -79.45107121 & 43.67162626 & 1133 & ULPU & $\begin{array}{r}462 \\
2803\end{array}$ \\
\hline 574 & 21-Jul-12 & -79.45116906 & 43.67163724 & $\begin{array}{l}1135 \\
1136,\end{array}$ & ULPU & $\begin{array}{r}163 \\
3.0708\end{array}$ \\
\hline 575 & 21-Jul-12 & -79.45118982 & 43.67160613 & 1137 & ULPU & $\begin{array}{r}678 \\
31102\end{array}$ \\
\hline 576 & 21-Jul-12 & -79.45121461 & 43.67161251 & $\begin{array}{l}1139 \\
1140,\end{array}$ & ACSA1 & $\begin{array}{r}379 \\
26771\end{array}$ \\
\hline 577 & 21-Jul-12 & -79.45124401 & 43.67163343 & 1141 & FRNI & 668 \\
\hline 578 & 21-Jul-12 & -79.45113853 & 43.67159578 & $\begin{array}{l}1142, \\
1144,\end{array}$ & FRNI & $\begin{array}{r}08 \\
2.4015\end{array}$ \\
\hline 579 & 21-Jul-12 & -79.45112652 & 43.67161011 & 1145 & FRPE & 761 \\
\hline
\end{tabular}

$\begin{array}{rrrrr}28.215224 & 22.309712 & 5.905512 & 13.4521 & 13.7802 \\ 43.307088 & 31.98819 & 11.318898 & 17.7174 & 14.1083 \\ 22.96588 & 13.779528 & 9.186352 & 10.1711 & 10.4992 \\ 34.44882 & 27.559056 & 6.889764 & 10.8273 & 13.4521 \\ 34.44882 & 26.082678 & 8.366142 & 8.2025 & 9.1868 \\ 40.846458 & 29.52756 & 11.318898 & 22.6389 & 15.7488 \\ 32.480316 & 16.240158 & 16.240158 & 18.0455 & 12.1397 \\ 21.981628 & 16.4042 & 5.577428 & 6.562 & 8.2025 \\ 31.16798 & 20.669292 & 10.498688 & 15.7488 & 13.124 \\ 22.96588 & 14.435696 & 8.530184 & 9.1868 & 9.5149 \\ 27.230972 & 22.637796 & 4.593176 & 13.4521 & 14.1083 \\ 35.433072 & 20.669292 & 14.76378 & 11.1554 & 8.2025 \\ 30.511812 & 16.240158 & 14.271654 & 10.4992 & 7.8744 \\ 28.051182 & 19.192914 & 8.858268 & 7.8744 & 7.5463 \\ 38.385828 & 17.22441 & 21.161418 & 10.8273 & 10.1711 \\ 57.742784 & 41.338584 & 16.4042 & 38.7158 & 30.8414 \\ 15.748032 & 12.139108 & 3.608924 & 14.4364 & 15.0926 \\ 33.792652 & 19.028872 & 14.76378 & 14.7645 & 12.1397 \\ 30.839896 & 21.32546 & 9.514436 & 11.4835 & 14.4364 \\ 29.855644 & 20.997376 & 8.858268 & 17.3893 & 13.7802 \\ 51.67323 & 43.47113 & 8.2021 & 43.3092 & 42.9811 \\ 61.023624 & 45.275592 & 15.748032 & 37.0753 & 24.9356 \\ 57.086616 & 35.925198 & 21.161418 & 42.3249 & 47.5745 \\ 23.129922 & 17.716536 & 5.413386 & 9.1868 & 10.4992 \\ 23.129922 & 18.208662 & 4.92126 & 8.2025 & 7.8744 \\ 28.215224 & 20.341208 & 7.874016 & 13.7802 & 13.4521 \\ 104.98688 & 92.68373 & 12.30315 & 77.4316 & 69.8853 \\ 31.496064 & 20.669292 & 10.826772 & 10.8273 & 8.8587 \\ 30.839896 & 19.68504 & 11.154856 & 14.7645 & 11.8116 \\ 23.950132 & 15.091864 & 8.858268 & 11.8116 & 9.1868\end{array}$




\begin{tabular}{|c|c|c|c|c|c|c|c|}
\hline 580 & 21-Jul-12 & -79.45111447 & 43.67162564 & 1147 & FRPE & $\begin{array}{r}2.4015 \\
761\end{array}$ & \\
\hline & 21-5ur-12 & & & 1148 & & 4.7244 & \\
\hline 581 & 21-Jul-12 & -79.45100453 & 43.67156741 & 1149 & ULPU & 12 & \\
\hline 582 & 21-Jul-12 & -79.45106063 & 43.67158507 & $\begin{array}{l}1150, \\
1151\end{array}$ & FRPE & $\begin{array}{r}4.1338 \\
605\end{array}$ & \\
\hline & & & & 1152, & & 5.1181 & \\
\hline 583 & 21-Jul-12 & -79.45103681 & 43.67154128 & 1153 & FRPE & 13 & \\
\hline 584 & 21-Jul-12 & -79.45101905 & 43.67152052 & $\begin{array}{l}1154, \\
1155\end{array}$ & FRPE & $\begin{array}{r}3.9370 \\
1\end{array}$ & \\
\hline 585 & $21-\mathrm{JuL}-12$ & -7945101462 & 4367149873 & 1156, & ALEX1 & $\begin{array}{r}3.1496 \\
08\end{array}$ & \\
\hline & 21-5ur-12 & & 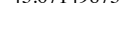 & & & 8.6614 & \\
\hline 586 & 21-Jul-12 & -79.44873352 & 43.67244502 & 1186 & JUNI & 22 & \\
\hline 587 & 21-Jul-12 & -79.44870511 & 43.67240639 & 1185 & JUNI & $\begin{array}{r}1.0800 \\
18\end{array}$ & $\begin{array}{r}5.018 \\
14\end{array}$ \\
\hline 588 & 21-Jul-12 & -79.448691 & 43.67238307 & 1184 & ACPL & $\begin{array}{r}2.3622 \\
06\end{array}$ & \\
\hline & & & & & & 2.6771 & \\
\hline 589 & 21-Jul-12 & -79.44868291 & 43.67236429 & 1183 & ACPL & 668 & \\
\hline 590 & 21-Jul-12 & -79.44868364 & 43.67233584 & 1182 & ACPL & $\begin{array}{r}3.3464 \\
585\end{array}$ & \\
\hline 591 & 21-Jul-12 & -79.44868304 & 43.67231181 & 1181 & JUNI & $\begin{array}{r}7.0866 \\
18 \\
1755\end{array}$ & \\
\hline 592 & 21-Jul-12 & -79.44866864 & 43.67230006 & 1180 & $\mathrm{ACPL}$ & 07 & \\
\hline 593 & 21-Jul-12 & -79.4486458 & 43.67228285 & 1179 & ACPL & $\begin{array}{r}3.5433 \\
09 \\
2.4409\end{array}$ & \\
\hline 594 & 21-Jul-12 & -79.44867542 & 43.67227436 & 1178 & JUNI & $\begin{array}{r}462 \\
4307\end{array}$ & \\
\hline 595 & 21-Jul-12 & -79.44868058 & 43.67226464 & 1177 & JUNI & $\begin{array}{r}11 \\
35433\end{array}$ & \\
\hline 596 & 21-Jul-12 & -79.44867255 & 43.67224319 & 1176 & JUNI & $\begin{array}{r}5.433 \\
09\end{array}$ & \\
\hline 597 & 21-Jul-12 & -79.44861673 & 43.67222197 & 1175 & $\mathrm{AM}$ & $\begin{array}{r}4.1338 \\
605 \\
3.0708\end{array}$ & \\
\hline 598 & 21-Jul-12 & -79.44862946 & 43.67220347 & 1174 & ACPL & 678 & \\
\hline 599 & $\begin{array}{l}\text { 21-Jul-12 } \\
\text { 13-Aug- }\end{array}$ & -79.44862752 & 43.67218388 & 1174 & ACPL & $\begin{array}{r}.1 .1308 \\
605 \\
2.9527\end{array}$ & \\
\hline 600 & & -79.44864698 & 43.67218948 & 1174 & ACPL & 575 & \\
\hline 601 & $\begin{array}{r}\text { 13-Aug- } \\
12\end{array}$ & -79.44861013 & 43.6721454 & 1173 & ACPL & $\begin{array}{r}3.1496 \\
08\end{array}$ & \\
\hline 602 & $\begin{array}{r}\text { 13-Aug- } \\
12\end{array}$ & -79.44859281 & 43.67210425 & 1172 & ACPL & $\begin{array}{r}4.3307 \\
11\end{array}$ & \\
\hline & 13-Aug- & & & & & 3.5433 & \\
\hline 603 & & -79.4485757 & 43.6720551 & 1171 & ACPL & 09 & \\
\hline & 13-Aug- & & & & & 3.3464 & \\
\hline & & -19.44858817 & $43.0 / 20463 /$ & $11 / 0$ & ACPL & 585 & \\
\hline 605 & $\begin{array}{r}\text { 13-Aug- } \\
12\end{array}$ & -79.44856994 & 43.67204079 & 1169 & ACPL & $\begin{array}{r}2.6771 \\
668\end{array}$ & \\
\hline & 13-Aug- & & & & & 2.4803 & \\
\hline 606 & 12 & -79.44855131 & 43.67205032 & 1168 & ACPL & 163 & \\
\hline & 13-Aug- & & & & & 2.5196 & \\
\hline 607 & & -79.44859732 & 43.67202426 & 1167 & ACPL & 864 & \\
\hline 608 & $\begin{array}{r}\text { 13-Aug- } \\
12\end{array}$ & -79.44861061 & 43.67203156 & 1166 & ACPL & $\begin{array}{r}3.1496 \\
08\end{array}$ & \\
\hline & 13-Aug- & & & & & 55118 & \\
\hline 609 & 12 & -79.44854198 & 43.67198438 & 1162 & ULGL & 14 & \\
\hline
\end{tabular}

\begin{tabular}{|c|c|c|c|c|}
\hline 24.6063 & 12.795276 & 11.811024 & 9.843 & 8.5306 \\
\hline 29.855644 & 18.04462 & 11.811024 & 14.1083 & 16.0769 \\
\hline 24.278216 & 13.451444 & 10.826772 & 11.8116 & 11.4835 \\
\hline 35.104988 & 20.997376 & 14.107612 & 12.4678 & 17.3893 \\
\hline 27.06693 & 18.208662 & 8.858268 & 14.1083 & 14.4364 \\
\hline 16.732284 & 12.30315 & 4.429134 & 12.1397 & 17.0612 \\
\hline 29.52756 & 21.653544 & 7.874016 & 21.9827 & 21.9827 \\
\hline 33.464568 & 26.902888 & 6.56168 & 19.686 & 22.967 \\
\hline 19.68504 & 13.12336 & 6.56168 & 8.8587 & 10.8273 \\
\hline 22.309712 & 15.748032 & 6.56168 & 12.1397 & 10.8273 \\
\hline 20.997376 & 15.091864 & 5.905512 & 6.562 & 8.5306 \\
\hline 32.8084 & 27.559056 & 5.249344 & 13.124 & 16.0769 \\
\hline 19.028872 & 13.12336 & 5.905512 & 6.8901 & 13.4521 \\
\hline 16.4042 & 11.154856 & 5.249344 & 12.7959 & 10.8273 \\
\hline 21.653544 & 15.091864 & 6.56168 & 7.2182 & 6.562 \\
\hline 25.590552 & 22.309712 & 3.28084 & 10.1711 & 11.4835 \\
\hline 19.68504 & 13.779528 & 5.905512 & 10.4992 & 12.4678 \\
\hline 19.028872 & 13.779528 & 5.249344 & 13.7802 & 9.843 \\
\hline 24.278216 & 17.716536 & 6.56168 & 11.1554 & 12.7959 \\
\hline 23.622048 & 16.4042 & 7.217848 & 9.1868 & 15.0926 \\
\hline 17.716536 & 13.12336 & 4.593176 & 6.562 & 8.2025 \\
\hline 22.96588 & 15.748032 & 7.217848 & 9.1868 & 9.843 \\
\hline 27.559056 & 21.653544 & 5.905512 & 10.8273 & 14.1083 \\
\hline 22.96588 & 16.4042 & 6.56168 & 6.8901 & 13.124 \\
\hline 27.559056 & 16.4042 & 11.154856 & 10.1711 & 8.2025 \\
\hline 28.215224 & 20.997376 & 7.217848 & 7.2182 & 6.562 \\
\hline 24.278216 & 19.68504 & 4.593176 & 6.8901 & 6.2339 \\
\hline 17.060368 & 9.84252 & 7.217848 & 10.1711 & 16.0769 \\
\hline 18.372704 & 6.56168 & 11.811024 & 8.2025 & 8.5306 \\
\hline 25.590552 & 17.716536 & 7.874016 & 7.5463 & 9.1868 \\
\hline
\end{tabular}

\begin{tabular}{|c|c|}
\hline 0 & 68 \\
\hline 0 & 0 \\
\hline 33 & 0 \\
\hline 0 & 0 \\
\hline 0 & 28 \\
\hline 0 & 0 \\
\hline 0 & 0 \\
\hline 0 & 0 \\
\hline 0 & 0 \\
\hline 0 & 0 \\
\hline 13 & 0 \\
\hline 0 & 0 \\
\hline 0 & 0 \\
\hline 0 & 0 \\
\hline 0 & 0 \\
\hline 0 & 0 \\
\hline 0 & 0 \\
\hline 0 & 28 \\
\hline 0 & 18 \\
\hline 0 & 18 \\
\hline 0 & 18 \\
\hline 18 & 13 \\
\hline 18 & 13 \\
\hline 18 & 13 \\
\hline 18 & 13 \\
\hline 18 & 13 \\
\hline 18 & 13 \\
\hline 28 & 0 \\
\hline 0 & 0 \\
\hline 0 & 0 \\
\hline
\end{tabular}




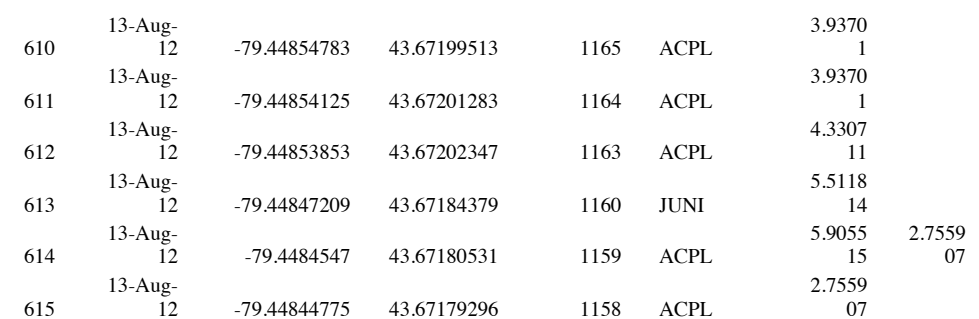

$\begin{array}{rrrrrrrr}22.96588 & 15.748032 & 7.217848 & 13.7802 & 13.124 & 18 & 8 & 3 \\ 28.871392 & 22.309712 & 6.56168 & 10.8273 & 8.5306 & 18 & 0 & 3 \\ 25.590552 & 18.372704 & 7.217848 & 6.8901 & 7.2182 & 23 & 13 & 3 \\ 22.96588 & 12.467192 & 10.498688 & 17.0612 & 16.7331 & 0 & 0 & 3 \\ 22.309712 & 12.467192 & 9.84252 & 14.1083 & 15.4207 & 0 & 0 & 4 \\ 17.716536 & 9.84252 & 7.874016 & 5.9058 & 12.1397 & 13 & 8 & 3\end{array}$


Appendix B: Individual Tree Characteristics (i-Tree Eco)

\begin{tabular}{|c|c|c|c|c|c|c|c|c|c|c|}
\hline Tree ID & Species Name & $\begin{array}{l}\text { DBH } \\
(\mathrm{cm})\end{array}$ & $\begin{array}{l}\text { Height } \\
\text { (m) }\end{array}$ & $\begin{array}{l}\text { Ground Area } \\
\text { (m2) }\end{array}$ & Tree Condition & $\begin{array}{l}\text { Leaf Area } \\
\text { (m2) }\end{array}$ & $\begin{array}{l}\text { Leaf Biomass } \\
(\mathrm{kg})\end{array}$ & $\begin{array}{l}\text { Leaf Area } \\
\text { Index }\end{array}$ & $\begin{array}{l}\text { Carbon } \\
\text { Storage (kg) }\end{array}$ & $\begin{array}{l}\text { Gross Carbon } \\
\text { Seq }(k g / y r)\end{array}$ \\
\hline 1 & Silver maple & 7.1 & 5 & 5.9 & Good & 23.87 & 1.26 & 4.04 & 7.7 & 1.08 \\
\hline 2 & Norway maple & 31.8 & 9.2 & 70.1 & Poor & 446.3 & 24.09 & 6.36 & 215.73 & 6.24 \\
\hline 3 & Norway maple & 39.9 & 10.4 & 92.5 & Critical & 559.1 & 30.18 & 6.05 & 362.28 & 4.61 \\
\hline 4 & Littleleaf linden & 51.3 & 11.6 & 150.4 & Excellent & 527.35 & 39.5 & 3.51 & 432.47 & 10.68 \\
\hline 5 & Norway maple & 46 & 13.2 & 133 & Good & 552.79 & 29.84 & 4.16 & 514.45 & 13.49 \\
\hline 6 & Littleleaf linden & 56.1 & 13.8 & 136.8 & Excellent & 537.57 & 40.27 & 3.93 & 534.58 & 12.06 \\
\hline 7 & Norway maple & 34.3 & 8.7 & 63.5 & Good & 424.06 & 22.89 & 6.68 & 253.17 & 8.98 \\
\hline 8 & Littleleaf linden & 49 & 10.1 & 111 & Excellent & 580.25 & 43.46 & 5.23 & 388.4 & 10.04 \\
\hline 9 & Littleleaf linden & 50.8 & 11.4 & 195 & Excellent & 604.59 & 45.29 & 3.1 & 422.44 & 10.53 \\
\hline 10 & Norway maple & 50 & 9.9 & 107.6 & Excellent & 573.91 & 30.98 & 5.33 & 593.4 & 14.51 \\
\hline 11 & Norway maple & 38.9 & 11.4 & 67 & Fair & 527.72 & 28.48 & 7.88 & 347.66 & 10.8 \\
\hline 12 & Norway maple & 33.8 & 9.6 & 63.1 & Good & 456.36 & 24.63 & 7.24 & 248.8 & 8.92 \\
\hline 13 & Littleleaf linden & 31 & 7.6 & 39.6 & Excellent & 205.74 & 15.41 & 5.19 & 131.69 & 5.41 \\
\hline 14 & Norway maple & 27.7 & 7.1 & 43.4 & Excellent & 288.19 & 15.55 & 6.63 & 153.54 & 6.76 \\
\hline 15 & Norway maple & 34.8 & 5.8 & 56 & Excellent & 232.62 & 12.56 & 4.16 & 248.35 & 8.82 \\
\hline 16 & Littleleaf linden & 46 & 12.8 & 56.8 & Excellent & 496.19 & 37.17 & 8.74 & 333.84 & 9.21 \\
\hline 17 & Littleleaf linden & 48.5 & 7.3 & 40.3 & Excellent & 248.3 & 18.6 & 6.16 & 378.97 & 9.9 \\
\hline 19 & Littleleaf linden & 48.5 & 7.5 & 50.9 & Excellent & 312.26 & 23.39 & 6.14 & 378.97 & 9.9 \\
\hline 20 & Green ash & 45.5 & 12 & 103.2 & Excellent & 446.97 & 29.15 & 4.33 & 236.31 & 5.58 \\
\hline 21 & Littleleaf linden & 77.3 & 8.3 & 46 & Good & 320.44 & 24 & 6.97 & 1135.07 & 18.57 \\
\hline 22 & Silver maple & 13.2 & 9.1 & 17.8 & Excellent & 112.42 & 5.92 & 6.33 & 36.65 & 2.74 \\
\hline 23 & Silver maple & 30.5 & 11.6 & 52 & Excellent & 298.93 & 15.73 & 5.75 & 184.08 & 6.23 \\
\hline 24 & Northern red oak & 28.2 & 7.8 & 60.9 & Excellent & 261.45 & 20.83 & 4.29 & 174.12 & 8.11 \\
\hline 25 & Norway maple & 61.2 & 14.2 & 170.9 & Fair & 754.82 & 40.74 & 4.42 & 974.46 & 19.32 \\
\hline 26 & Norway maple & 54.1 & 11.6 & 135.5 & Excellent & 385.83 & 20.82 & 2.85 & 720.15 & 16.23 \\
\hline 27 & Norway maple & 45 & 13.4 & 72.4 & Good & 541.65 & 29.23 & 7.48 & 491.31 & 13.15 \\
\hline 29 & Norway maple & 55.4 & 13 & 98.3 & Fair & 592.82 & 32 & 6.03 & 771.37 & 16.91 \\
\hline 30 & Norway maple & 57.9 & 14.6 & 192 & Good & 921.72 & 49.75 & 4.8 & 866.69 & 18.1 \\
\hline 31 & Norway maple & 28.4 & 9.4 & 58.9 & Poor & 373.61 & 20.17 & 6.35 & 170.42 & 5.47 \\
\hline 32 & Honeylocust & 32.8 & 10.5 & 74.7 & Excellent & 148.91 & 15.59 & 1.99 & 226.97 & 9.01 \\
\hline 36 & Eastern white pine & 45 & 11.9 & 46.7 & Excellent & 257.77 & 16.58 & 5.52 & 251.05 & 7.09 \\
\hline 37 & Eastern white pine & 40.1 & 12.4 & 36.3 & Excellent & 201.67 & 12.97 & 5.56 & 190.8 & 6.04 \\
\hline
\end{tabular}




$\begin{array}{llrr}38 & \text { Eastern white pine } & 34.3 & 12.9 \\ 39 & \text { Eastern white pine } & 40.4 & 9.8 \\ 40 & \text { Eastern white pine } & 39.1 & 9.1 \\ 41 & \text { Eastern white pine } & 31 & 9.6 \\ 42 & \text { Eastern white pine } & 34 & 10.6 \\ 43 & \text { Eastern white pine } & 23.9 & 7.8 \\ 44 & \text { Eastern white pine } & 23.1 & 7.5 \\ 45 & \text { Green ash } & 88.6 & 16.4 \\ 46 & \text { Silver maple } & 56.1 & 11.7 \\ 47 & \text { Norway maple } & 67.1 & 15.2 \\ 48 & \text { Norway maple } & 65 & 16.4 \\ 49 & \text { Silver maple } & 79.2 & 14 \\ 50 & \text { London plane } & 64.3 & 20.4 \\ 51 & \text { Norway maple } & 57.9 & 15 \\ 52 & \text { Silver maple } & 67.6 & 15.8 \\ 53 & \text { Norway maple } & 50 & 15.4 \\ 55 & \text { Red pine } & 8.9 & 4.5 \\ 56 & \text { Eastern white pine } & 10.9 & 4.8 \\ 57 & \text { Eastern white pine } & 10.4 & 3.5 \\ 58 & \text { Eastern white pine } & 7.9 & 3.5 \\ 59 & \text { Eastern white pine } & 8.9 & 5 \\ 62 & \text { Norway maple } & 41.9 & 9.2 \\ 63 & \text { Norway maple } & 30.5 & 6.6 \\ 64 & \text { Norway maple } & 41.9 & 10.4 \\ 65 & \text { Blue spruce } & 11.9 & 5.3 \\ 66 & \text { Blue spruce } & 11.9 & 6.5 \\ 67 & \text { Douglas fir } & 11.9 & 6.5 \\ 68 & \text { Douglas fir } & 11.9 & 6.5 \\ 69 & \text { Douglas fir } & 11.9 & 6.5 \\ 70 & \text { serviceberry spp } & 20.6 & 8.8 \\ 71 & \text { Norway maple } & 31 & 9.6 \\ 72 & \text { Honeylocust } & 10.4 & 6 \\ 73 & \text { Honeylocust } & 9.4 & 5.7 \\ 74 & \text { Honeylocust } & 8.9 & 5.7 \\ 75 & \text { Honeylocust } & 32.8 & 12.6 \\ 76 & \text { Honeylocust } & 7.1 & 5.7 \\ 77 \text { Red maple } & 7.9 & 5.2\end{array}$

$\begin{aligned} 19.1 & \text { Excellent } \\ 31.6 & \text { Excellent } \\ 25.5 & \text { Fair } \\ 18.9 & \text { Excellent } \\ 23.4 & \text { Fair } \\ 17.3 & \text { Good } \\ 22.9 & \text { Excellent } \\ 338.4 & \text { Fair } \\ 193.5 & \text { Good } \\ 261.8 & \text { Excellent } \\ 169.5 & \text { Excellent } \\ 282.3 & \text { Excellent } \\ 213.6 & \text { Excellent } \\ 268.8 & \text { Excellent } \\ 330.5 & \text { Excellent } \\ 103.7 & \text { Excellent } \\ 4.6 & \text { Excellent } \\ 12 & \text { Excellent } \\ 8.5 & \text { Excellent } \\ 5.5 & \text { Excellent } \\ 9.2 & \text { Excellent } \\ 134.9 & \text { Excellent } \\ 37.3 & \text { Excellent } \\ 86.8 & \text { Excellent } \\ 7.6 & \text { Excellent } \\ 12.9 & \text { Excellent } \\ 12.9 & \text { Excellent } \\ 12.9 & \text { Excellent } \\ 12.9 & \text { Excellent } \\ 22.6 & \text { Excellent } \\ 64.4 & \text { Poor } \\ 16.6 & \text { Excellent } \\ 14.1 & \text { Excellent } \\ 11.6 & \text { Excellent } \\ 147.1 & \text { Excellent } \\ 12.5 & \text { Excellent } \\ & \end{aligned}$

\begin{tabular}{|c|c|c|}
\hline 105.18 & 6.76 & 5.49 \\
\hline 144.99 & 9.32 & 4.59 \\
\hline 124.25 & 7.99 & 4.87 \\
\hline 64.45 & 4.14 & 3.41 \\
\hline 117.09 & 7.53 & 5.01 \\
\hline 58.97 & 3.79 & 3.41 \\
\hline 77.9 & 5.01 & 3.41 \\
\hline 778.29 & 50.76 & 2.3 \\
\hline 445.11 & 23.43 & 2.3 \\
\hline 1518.46 & 81.96 & 5.8 \\
\hline 1152.72 & 62.22 & 6.8 \\
\hline 1016.26 & 53.49 & 3.6 \\
\hline 1601.68 & 73.57 & 7.5 \\
\hline 1218.12 & 65.75 & 4.53 \\
\hline 1454.13 & 76.53 & 4.4 \\
\hline 746.68 & 40.3 & 7.2 \\
\hline 18.35 & 2.7 & 4.03 \\
\hline 48.85 & 3.14 & 4.09 \\
\hline 29.87 & 1.92 & 3.51 \\
\hline 20.47 & 1.32 & 3.71 \\
\hline 31.19 & 2.01 & 3.41 \\
\hline 626.41 & 33.81 & 4.64 \\
\hline 188.67 & 10.18 & 5.06 \\
\hline 563.41 & 30.41 & 6.49 \\
\hline 52.47 & 8.9 & 6.91 \\
\hline 106.79 & 18.12 & 8.27 \\
\hline 106.79 & 16.72 & 8.27 \\
\hline 106.79 & 16.72 & 8.27 \\
\hline 106.79 & 16.72 & 8.27 \\
\hline 90.77 & 6.88 & 4.02 \\
\hline 462.46 & 24.96 & 7.19 \\
\hline 23.68 & 2.48 & 1.42 \\
\hline 19.55 & 2.05 & 1.39 \\
\hline 16.79 & 1.76 & 1.45 \\
\hline 154.2 & 16.15 & 1.05 \\
\hline 20.01 & 2.09 & 1.6 \\
\hline 28.97 & 1.95 & 3.6 \\
\hline
\end{tabular}

$\begin{array}{rr}129.47 & 4.83 \\ 192.2 & 6.09 \\ 177.62 & 5.82 \\ 100.84 & 4.19 \\ 127.52 & 4.78 \\ 54.24 & 2.9 \\ 50.74 & 2.77 \\ 942.93 & 12.18 \\ 523.52 & 10.52 \\ 1203.03 & 21.78 \\ 1138.27 & 21.15 \\ 1091.81 & 16.07 \\ 1192.82 & 24.01 \\ 870.51 & 18.16 \\ 923.23 & 15.07 \\ 635.71 & 15.25 \\ 9.78 & 1.24 \\ 9.18 & 0.97 \\ 7.82 & 0.91 \\ 4.11 & 0.62 \\ 5.61 & 0.73 \\ 397.19 & 11.57 \\ 188.02 & 7.56 \\ 404.06 & 11.71 \\ 21.52 & 1.85 \\ 25.21 & 1.85 \\ 11.29 & 0.46 \\ 11.29 & 0.46 \\ 11.29 & 0.46 \\ 73.98 & 4.68 \\ 205.97 & 6.09 \\ 14.26 & 1.8 \\ 11.14 & 1.45 \\ 9.77 & 91 \\ 230.27 & 5.78 \\ 8.39 & \end{array}$




$\begin{array}{rlrr}78 & \text { Red maple } & 7.9 & 4.7 \\ 79 & \text { Northern red oak } & 6.9 & 4.2 \\ 80 & \text { Bur oak } & 37.8 & 15.6 \\ 81 & \text { Bur oak } & 23.1 & 11 \\ 82 & \text { Northern red oak } & 7.4 & 5.9 \\ 83 & \text { Littleleaf linden } & 75.2 & 11.8 \\ 84 & \text { Honeylocust } & 38.1 & 13 \\ 85 & \text { Littleleaf linden } & 55.6 & 15.4 \\ 86 & \text { Honeylocust } & 56.9 & 17.5 \\ 87 & \text { Littleleaf linden } & 57.9 & 14 \\ 88 & \text { Honeylocust } & 45.5 & 12.3 \\ 89 & \text { Norway maple } & 37.1 & 11 \\ 90 & \text { Honeylocust } & 34.3 & 10.2 \\ 91 & \text { Honeylocust } & 31.5 & 7.4 \\ 92 & \text { Red maple } & 42.9 & 11.8 \\ 93 & \text { Norway maple } & 56.9 & 14 \\ 94 & \text { Silver maple } & 59.9 & 14 \\ 95 & \text { Honeylocust } & 63 & 11.8 \\ 96 & \text { Honeylocust } & 40.9 & 13.6 \\ 97 & \text { Littleleaf linden } & 56.9 & 9.8 \\ 98 & \text { Littleleaf linden } & 54.1 & 13.2 \\ 99 & \text { Red maple } & 19.1 & 7.9 \\ 100 & \text { Green ash } & 34 & 12.8 \\ 101 & \text { Norway maple } & 43.9 & 12.8 \\ 102 & \text { Honeylocust } & 50 & 15 \\ 103 & \text { Norway maple } & 31 & 10.6 \\ 104 & \text { Honeylocust } & 31 & 12 \\ 105 & \text { Littleleaf linden } & 55.1 & 15 \\ 106 & \text { Norway maple } & 70.1 & 15.4 \\ 107 & \text { Littleleaf linden } & 51.1 & 15.6 \\ 108 & \text { Littleleaf linden } & 83.1 & 16 \\ 109 & \text { Norway maple } & 47 & 13 \\ 110 & \text { Norway maple } & 49 & 15.4 \\ 111 & \text { Littleleaf linden } & 27.9 & 7.2 \\ 112 & \text { Green ash } & 42.9 & 12.4 \\ 113 & \text { Norway maple } & 55.9 & 14 \\ 114 & \text { Norway maple } & 50 & 12.2\end{array}$

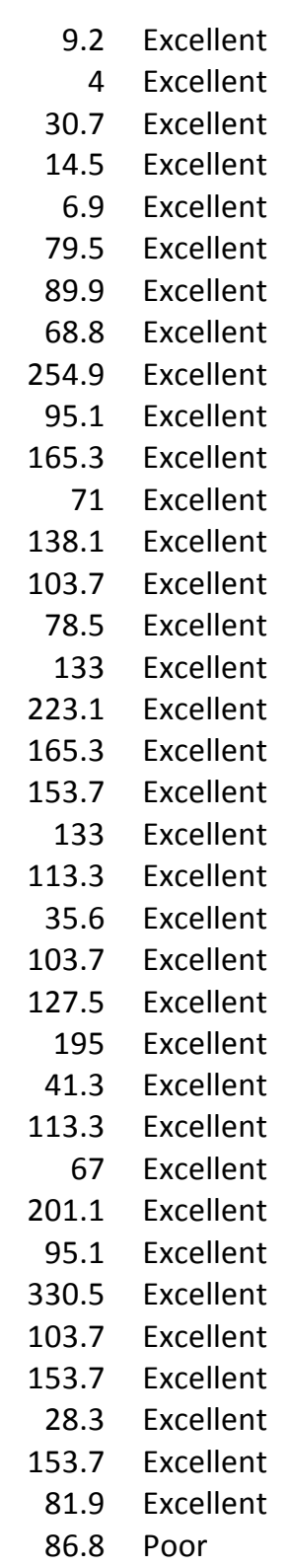

\begin{tabular}{|c|c|}
\hline 2.11 & 3.43 \\
\hline 1.03 & 3.22 \\
\hline 16.34 & 5.4 \\
\hline 9.65 & 6.74 \\
\hline 2.28 & 4.17 \\
\hline 43.08 & 7.24 \\
\hline 18.96 & 2.01 \\
\hline 51.38 & 9.97 \\
\hline 50.7 & 1.9 \\
\hline 48.01 & 6.74 \\
\hline 24.24 & 1.4 \\
\hline 28.16 & 7.35 \\
\hline 17.72 & 1.23 \\
\hline 17.41 & 1.6 \\
\hline 30.04 & 5.68 \\
\hline 29.49 & 4.11 \\
\hline 51.67 & 4.4 \\
\hline 29.43 & 1.7 \\
\hline 14.79 & 0.92 \\
\hline 42.52 & 4.27 \\
\hline 44.48 & 5.24 \\
\hline 9.67 & 4.03 \\
\hline 30.35 & 4.49 \\
\hline 30.67 & 4.46 \\
\hline 38.8 & 1.9 \\
\hline 13.79 & 6.18 \\
\hline 18.31 & 1.54 \\
\hline 45.83 & 9.13 \\
\hline 69.47 & 6.4 \\
\hline 52.71 & 7.4 \\
\hline 143.58 & 5.8 \\
\hline 33.08 & 5.91 \\
\hline 41.74 & 5.03 \\
\hline 12.09 & 5.7 \\
\hline 25.4 & 2.53 \\
\hline 24.3 & 5.5 \\
\hline 23.05 & 4.92 \\
\hline
\end{tabular}

\begin{tabular}{|c|c|}
\hline 8.39 & 1.41 \\
\hline 5.61 & 1.12 \\
\hline 325.81 & 11.57 \\
\hline 95.33 & 5.58 \\
\hline 6.68 & 1.24 \\
\hline 1064.75 & 17.9 \\
\hline 330.63 & 11.25 \\
\hline 523.24 & 11.91 \\
\hline 880.93 & 20.06 \\
\hline 575.37 & 12.57 \\
\hline 501.98 & 14.36 \\
\hline 311.99 & 10.15 \\
\hline 252.51 & 9.58 \\
\hline 201.92 & 8.38 \\
\hline 463.15 & 13.73 \\
\hline 828.03 & 17.63 \\
\hline 680.51 & 12.53 \\
\hline 1094.99 & 22.72 \\
\hline 392.74 & 12.45 \\
\hline 551.85 & 12.28 \\
\hline 490.06 & 11.47 \\
\hline 67.81 & 4.58 \\
\hline 153.27 & 4.61 \\
\hline 463.68 & 12.72 \\
\hline 640.51 & 16.61 \\
\hline 209.53 & 8.13 \\
\hline 200.86 & 8.4 \\
\hline 512.04 & 11.76 \\
\hline 1328.84 & 23.03 \\
\hline 427.43 & 10.61 \\
\hline 1346.63 & 20.48 \\
\hline 538.35 & 13.83 \\
\hline 607.96 & 14.88 \\
\hline 103.16 & 4.7 \\
\hline 220.48 & 5.44 \\
\hline 795.97 & 17.24 \\
\hline 611.38 & 11.25 \\
\hline
\end{tabular}




\begin{tabular}{|c|c|c|c|c|c|c|c|c|c|c|}
\hline 115 & Littleleaf linden & 37.1 & 14.6 & 86.8 & Excellent & 625.3 & 46.84 & 7.2 & 201.13 & 6.89 \\
\hline 116 & Honeylocust & 53.1 & 14.4 & 227.2 & Excellent & 386.22 & 40.44 & 1.7 & 735.47 & 18 \\
\hline 117 & Norway maple & 40.9 & 14 & 33.1 & Excellent & 475.2 & 25.65 & 14.35 & 402.83 & 11.79 \\
\hline 118 & Norway maple & 34 & 11 & 38.6 & Excellent & 387.39 & 20.91 & 10.04 & 258.72 & 9.15 \\
\hline 119 & Littleleaf linden & 41.9 & 15.4 & 38.6 & Excellent & 339.67 & 25.44 & 8.8 & 268.38 & 8.12 \\
\hline 120 & Littleleaf linden & 37.1 & 12.8 & 47.1 & Excellent & 555.53 & 41.61 & 11.8 & 201.13 & 6.89 \\
\hline 121 & Norway maple & 41.9 & 13.8 & 50.1 & Excellent & 395.69 & 21.36 & 7.9 & 423.86 & 12.13 \\
\hline 122 & Norway maple & 39.1 & 13 & 50.1 & Excellent & 344.66 & 18.6 & 6.88 & 360.89 & 11.07 \\
\hline 123 & Norway maple & 43.9 & 15.3 & 90.9 & Excellent & 471.52 & 25.45 & 5.19 & 478.88 & 13.02 \\
\hline 124 & Green ash & 32 & 15.4 & 103.7 & Good & 385.42 & 25.14 & 3.72 & 161.36 & 5.03 \\
\hline 125 & Norway maple & 32 & 12.4 & 60.1 & Excellent & 258.76 & 13.97 & 4.31 & 231.38 & 8.64 \\
\hline 126 & Green ash & 34 & 16.4 & 95.1 & Poor & 386.36 & 25.2 & 4.06 & 188.72 & 4.2 \\
\hline 128 & White oak & 87.1 & 26 & 298.9 & Excellent & 826.79 & 60.14 & 2.77 & 2891.61 & 44.63 \\
\hline 129 & Norway maple & 75.9 & 17 & 268.8 & Excellent & 1720.59 & 92.87 & 6.4 & 1608.87 & 25.71 \\
\hline 130 & apple spp & 10.9 & 4.7 & 7.7 & Excellent & 34.84 & 3 & 4.5 & 15.65 & 1.89 \\
\hline 131 & Norway maple & 52.1 & 14 & 122.7 & Excellent & 580.47 & 31.33 & 4.73 & 681.97 & 15.81 \\
\hline 132 & Honeylocust & 47 & 15.4 & 201.1 & Excellent & 341.89 & 35.8 & 1.7 & 552.45 & 15.23 \\
\hline 133 & Norway maple & 30 & 8.1 & 38.6 & Excellent & 207.72 & 11.21 & 5.38 & 186.4 & 7.56 \\
\hline 135 & Honeylocust & 42.9 & 14.4 & 133 & Excellent & 167.09 & 17.5 & 1.26 & 442.87 & 13.37 \\
\hline 137 & Littleleaf linden & 31 & 11 & 44.2 & Excellent & 386.32 & 28.94 & 8.75 & 131.69 & 5.41 \\
\hline 138 & Honeylocust & 7.1 & 4.6 & 8.4 & Excellent & 6.43 & 0.67 & 0.77 & 5.66 & 1.06 \\
\hline 139 & Honeylocust & 6.1 & 4.5 & 12.5 & Excellent & 10.4 & 1.09 & 0.83 & 3.93 & 0.86 \\
\hline 140 & Norway maple & 30 & 10.4 & 50.1 & Excellent & 395.69 & 21.36 & 7.9 & 194.16 & 7.79 \\
\hline 141 & Honeylocust & 38.1 & 12 & 135.5 & Excellent & 167.72 & 17.56 & 1.24 & 328.58 & 11.2 \\
\hline 142 & Bur oak & 77 & 22.5 & 283.2 & Excellent & 1189.45 & 117.38 & 4.2 & 1910.95 & 33.18 \\
\hline 143 & Littleleaf linden & 51.1 & 15.4 & 133 & Excellent & 669.31 & 50.14 & 5.03 & 427.43 & 10.61 \\
\hline 144 & Norway maple & 50 & 12 & 148.4 & Excellent & 422.59 & 22.81 & 2.85 & 609.96 & 14.8 \\
\hline 145 & Norway maple & 32 & 9.4 & 86.8 & Fair & 257.52 & 13.9 & 2.97 & 220.22 & 8.33 \\
\hline 146 & Northern red oak & 69.1 & 17.2 & 240.4 & Excellent & 1033.74 & 82.37 & 4.3 & 1536.42 & 28.98 \\
\hline 147 & London plane & 36.1 & 15 & 176.6 & Excellent & 1201.05 & 55.17 & 6.8 & 293.79 & 10.52 \\
\hline 148 & Black ash & 53.1 & 17.4 & 189 & Excellent & 880.18 & 52.39 & 4.66 & 571.25 & 13.27 \\
\hline 149 & Norway maple & 43.9 & 12.2 & 165.3 & Excellent & 958.88 & 51.75 & 5.8 & 459.9 & 12.64 \\
\hline 150 & Northern red oak & 66 & 17.8 & 213.6 & Excellent & 982.37 & 78.28 & 4.6 & 1376.9 & 27.17 \\
\hline 151 & White oak & 71.1 & 22 & 213.6 & Good & 594.54 & 43.25 & 2.78 & 1737.62 & 32.89 \\
\hline 152 & Norway maple & 48 & 16 & 176.6 & Excellent & 1201.05 & 64.82 & 6.8 & 585.14 & 14.58 \\
\hline 153 & Littleleaf linden & 48 & 17 & 113.3 & Excellent & 592.51 & 44.38 & 5.23 & 369.68 & 9.76 \\
\hline 154 & Bur oak & 72.9 & 20.6 & 298.9 & Excellent & 966.06 & 95.34 & 3.23 & 1669.28 & 30.61 \\
\hline
\end{tabular}




$\begin{array}{llrr}155 & \text { Norway maple } & 47 & 16.8 \\ 156 & \text { Norway maple } & 39.1 & 9.8 \\ 157 & \text { Littleleaf linden } & 67.1 & 17.4 \\ 158 & \text { White oak } & 87.9 & 24 \\ 159 & \text { Norway maple } & 56.9 & 14.6 \\ 160 & \text { Norway maple } & 55.1 & 12.4 \\ 161 & \text { White oak } & 74.9 & 20.6 \\ 162 & \text { Bur oak } & 62 & 22.4 \\ 163 & \text { Bur oak } & 80 & 25 \\ 164 & \text { Norway maple } & 57.9 & 18 \\ 165 & \text { Norway maple } & 57.9 & 13.8 \\ 166 & \text { Bur oak } & 72.9 & 21 \\ 167 & \text { Norway maple } & 52.1 & 14.8 \\ 168 & \text { Littleleaf linden } & 69.1 & 14.4 \\ 169 & \text { Silver maple } & 64 & 22.4 \\ 170 & \text { Tulip tree } & 6.6 & 5.5 \\ 171 & \text { Silver maple } & 59.9 & 19.4 \\ 172 & \text { Honeylocust } & 45 & 12.6 \\ 173 & \text { American sycamore } & 41.9 & 16.8 \\ 174 & \text { Sugar maple } & 51.1 & 16.8 \\ 175 & \text { Littleleaf linden } & 52.1 & 12.8 \\ 176 & \text { Norway maple } & 53.1 & 13 \\ 177 & \text { Littleleaf linden } & 61 & 10.2 \\ 178 & \text { Norway maple } & 46.5 & 15.2 \\ 179 & \text { Norway maple } & 54.1 & 10.6 \\ 180 & \text { Norway maple } & 50 & 11.2 \\ & \text { American } & & \\ 181 & \text { basswood } & 7.9 & 4.4 \\ 182 & \text { Northern catalpa } & 46 & 9.8 \\ 183 & \text { Silver maple } & 59.9 & 14.2 \\ 184 & \text { Norway maple } & 53.1 & 12.8 \\ 185 & \text { Norway maple } & 50 & 13.4 \\ 186 & \text { Honeylocust } & 49 & 14.8 \\ 187 & \text { Honeylocust } & 37.1 & 11.2 \\ 188 & \text { Honeylocust } & 35.1 & 9.6 \\ 189 & \text { Honeylocust } & 49 & 11 \\ 190 & \text { Honeylocust } & 7.9 & 5.8\end{array}$

\begin{tabular}{|c|c|}
\hline 143.2 & Poor \\
\hline 78.5 & Good \\
\hline 213.6 & Excellent \\
\hline 451.9 & Excellent \\
\hline 165.3 & Excellent \\
\hline 254.9 & Excellent \\
\hline 346.4 & Excellent \\
\hline 283.2 & Excellent \\
\hline 330.5 & Excellent \\
\hline 213.6 & Excellent \\
\hline 291.4 & Excellent \\
\hline 298.9 & Excellent \\
\hline 122.7 & Excellent \\
\hline 176.6 & Excellent \\
\hline 298.9 & Excellent \\
\hline 9.6 & Excellent \\
\hline 227.2 & Excellent \\
\hline 165.3 & Excellent \\
\hline 153.7 & Excellent \\
\hline 153.7 & Excellent \\
\hline 103.7 & Excellent \\
\hline 138.1 & Fair \\
\hline 95.1 & Excellent \\
\hline 153.7 & Excellent \\
\hline 143.2 & Excellent \\
\hline 165.3 & Excellent \\
\hline 11 & Excellent \\
\hline 86.8 & Fair \\
\hline 195 & Fair \\
\hline 122.7 & Excellent \\
\hline 133 & Excellent \\
\hline 240.4 & Excellent \\
\hline 122.7 & Excellent \\
\hline 78.5 & Excellent \\
\hline 176.6 & Excellent \\
\hline 21.6 & Excellent \\
\hline
\end{tabular}

\begin{tabular}{|c|c|c|}
\hline 741.89 & 40.04 & 5.18 \\
\hline 342.97 & 18.51 & 4.37 \\
\hline 1452.19 & 108.78 & 6.8 \\
\hline 1182.42 & 86.01 & 2.62 \\
\hline 749.08 & 40.43 & 4.53 \\
\hline 1027.32 & 55.45 & 4.03 \\
\hline 826.82 & 60.15 & 2.39 \\
\hline 616.14 & 60.81 & 2.18 \\
\hline 1388.03 & 136.98 & 4.2 \\
\hline 1452.19 & 78.38 & 6.8 \\
\hline 1398.93 & 75.5 & 4.8 \\
\hline 817.71 & 80.7 & 2.74 \\
\hline 584.64 & 31.55 & 4.77 \\
\hline 1130.4 & 84.67 & 6.4 \\
\hline 1524.23 & 80.22 & 5.1 \\
\hline 47.78 & 2.82 & 4.95 \\
\hline 950.11 & 50.01 & 4.18 \\
\hline 223.34 & 23.39 & 1.35 \\
\hline 1152.94 & 55.86 & 7.5 \\
\hline 647.14 & 38.98 & 4.21 \\
\hline 477.09 & 35.74 & 4.6 \\
\hline 425.93 & 22.99 & 3.08 \\
\hline 551.13 & 41.28 & 5.8 \\
\hline 472.8 & 25.52 & 3.08 \\
\hline 536.58 & 28.96 & 3.75 \\
\hline 571.36 & 30.84 & 3.46 \\
\hline 42.61 & 1.24 & 3.86 \\
\hline 169.05 & 10.29 & 1.95 \\
\hline 489.14 & 25.74 & 2.51 \\
\hline 504.28 & 27.22 & 4.11 \\
\hline 551.8 & 29.78 & 4.15 \\
\hline 408.69 & 42.79 & 1.7 \\
\hline 191.31 & 20.03 & 1.56 \\
\hline 142.17 & 14.89 & 1.81 \\
\hline 158.96 & 16.65 & 0.9 \\
\hline 27.61 & 2.89 & 1.28 \\
\hline
\end{tabular}

\begin{tabular}{|c|c|}
\hline 563.88 & 10.86 \\
\hline 344.38 & 10.7 \\
\hline 812.98 & 15.33 \\
\hline 2955.5 & 45.22 \\
\hline 833.75 & 17.72 \\
\hline 758.1 & 16.73 \\
\hline 1980.76 & 35.58 \\
\hline 1113.87 & 24.05 \\
\hline 2105.19 & 35.15 \\
\hline 899.09 & 18.59 \\
\hline 859.01 & 17.99 \\
\hline 1669.28 & 30.61 \\
\hline 688.62 & 15.93 \\
\hline 872.28 & 15.96 \\
\hline 1132.94 & 18.37 \\
\hline 4.07 & 0.83 \\
\hline 896.95 & 15.7 \\
\hline 489.59 & 14.16 \\
\hline 424.01 & 13.06 \\
\hline 802.79 & 19.46 \\
\hline 447.76 & 10.89 \\
\hline 703.2 & 16.06 \\
\hline 649.34 & 13.48 \\
\hline 540.38 & 13.93 \\
\hline 711.67 & 16.09 \\
\hline 603.53 & 14.69 \\
\hline 5.21 & 0.87 \\
\hline 508.44 & 14.44 \\
\hline 689.29 & 12.66 \\
\hline 701.39 & 16.03 \\
\hline 620.75 & 14.99 \\
\hline 609.32 & 16.12 \\
\hline 306.44 & 10.74 \\
\hline 265.03 & 9.85 \\
\hline 597.11 & 15.89 \\
\hline 7.36 & 1.23 \\
\hline
\end{tabular}




\begin{tabular}{|c|c|c|c|c|c|c|c|c|c|c|}
\hline 191 & Honeylocust & 8.6 & 6.5 & 30.7 & Excellent & 51.08 & 5.35 & 1.67 & 9.25 & 1.41 \\
\hline 192 & Honeylocust & 7.9 & 5.2 & 11 & Excellent & 15.48 & 1.62 & 1.4 & 7.28 & 1.22 \\
\hline 193 & Norway maple & 57.9 & 14.6 & 165.3 & Excellent & 1058.07 & 57.11 & 6.4 & 866.69 & 18.1 \\
\hline 194 & Swamp white oak & 103.1 & 20 & 530.9 & Excellent & 1367.62 & 134.97 & 2.58 & 4488.5 & 52.32 \\
\hline 195 & Norway maple & 61 & 15.6 & 153.7 & Excellent & 1045.33 & 56.42 & 6.8 & 980.32 & 19.43 \\
\hline 196 & Norway maple & 48 & 13 & 133 & Poor & 373.4 & 20.15 & 2.81 & 564.13 & 10.77 \\
\hline 197 & Littleleaf linden & 78 & 14.6 & 133 & Excellent & 549.98 & 41.2 & 4.13 & 1160.42 & 18.8 \\
\hline 198 & Norway maple & 39.1 & 14 & 38.6 & Excellent & 529.22 & 28.56 & 13.71 & 365.8 & 11.18 \\
\hline 199 & Norway maple & 34 & 11 & 41.3 & Excellent & 386.52 & 20.86 & 9.35 & 258.72 & 9.15 \\
\hline 201 & Honeylocust & 61 & 17.4 & 268.8 & Excellent & 444.4 & 46.53 & 1.65 & 1038.26 & 22.09 \\
\hline 202 & Red pine & 24.9 & 7.8 & 35.6 & Fair & 160.74 & 23.64 & 4.51 & 100.68 & 4.52 \\
\hline 203 & $\begin{array}{l}\text { Red pine } \\
\text { American }\end{array}$ & 26.9 & 9.2 & 33.1 & Fair & 192.85 & 28.36 & 5.83 & 120.46 & 5 \\
\hline 204 & $\begin{array}{l}\text { basswood } \\
\text { American }\end{array}$ & 56.9 & 19.6 & 86.8 & Excellent & 668.73 & 19.52 & 7.7 & 551.85 & 12.28 \\
\hline 205 & $\begin{array}{l}\text { basswood } \\
\text { American }\end{array}$ & 41.9 & 13 & 26.1 & Good & 186.56 & 5.45 & 7.16 & 268.38 & 8.12 \\
\hline 206 & basswood & 48 & 16.6 & 56.8 & Excellent & 448.7 & 13.1 & 7.9 & 369.68 & 9.76 \\
\hline 207 & Norway maple & 51.1 & 13 & 113.3 & Excellent & 583.14 & 31.47 & 5.15 & 645.53 & 15.31 \\
\hline 208 & Silver maple & 105.9 & 21.8 & 254.9 & Excellent & 1035.49 & 54.5 & 4.06 & 2593.92 & 27.63 \\
\hline 209 & Norway maple & 38.1 & 12 & 90.9 & Excellent & 296.58 & 16.01 & 3.26 & 335.94 & 10.61 \\
\hline 210 & Norway maple & 39.1 & 14.6 & 19.6 & Excellent & 64.02 & 3.46 & 3.26 & 368.83 & 11.25 \\
\hline 211 & Norway maple & 39.9 & 14.8 & 28.3 & Excellent & 92.37 & 4.99 & 3.26 & 385.66 & 11.54 \\
\hline 212 & Norway maple & 53.1 & 20.2 & 189 & Excellent & 616.64 & 33.28 & 3.26 & 762.25 & 17.04 \\
\hline 213 & Norway maple & 64 & 18 & 176.6 & Excellent & 576.14 & 31.1 & 3.26 & 1117.75 & 21 \\
\hline 214 & Sugar maple & 37.1 & 13.8 & 78.5 & Excellent & 490.47 & 29.55 & 6.25 & 384.31 & 12.86 \\
\hline 215 & Sugar maple & 41.9 & 11.8 & 143.2 & Excellent & 368.44 & 22.2 & 2.57 & 509.45 & 15.06 \\
\hline 216 & Sugar maple & 35.1 & 14 & 103.7 & Excellent & 514.33 & 30.98 & 4.96 & 337.51 & 11.95 \\
\hline 217 & Norway maple & 57.9 & 14 & 153.7 & Poor & 394.8 & 21.31 & 2.57 & 860.79 & 13.67 \\
\hline 218 & Sugar maple & 38.1 & 13.6 & 133 & Excellent & 436.02 & 26.27 & 3.28 & 409 & 13.31 \\
\hline 219 & Sugar maple & 55.1 & 15.8 & 165.3 & Excellent & 591.1 & 35.61 & 3.58 & 957.74 & 21.49 \\
\hline 220 & Honeylocust & 35.1 & 14.2 & 143.2 & Excellent & 151.5 & 15.86 & 1.06 & 273.17 & 10.07 \\
\hline 221 & $\begin{array}{l}\text { Littleleaf linden } \\
\text { American }\end{array}$ & 52.1 & 14.8 & 133 & Excellent & 944.57 & 70.75 & 7.1 & 447.76 & 10.89 \\
\hline 222 & $\begin{array}{l}\text { basswood } \\
\text { American }\end{array}$ & 43.9 & 12.6 & 103.7 & Excellent & 473.8 & 13.83 & 4.57 & 300.08 & 8.66 \\
\hline 223 & basswood & 53.1 & 16.8 & 103.7 & Excellent & 767.42 & 22.41 & 7.4 & 468.64 & 11.18 \\
\hline
\end{tabular}




\begin{tabular}{|c|c|c|c|c|c|c|c|c|c|c|}
\hline 224 & Norway maple & 40.9 & 14.4 & 122.7 & Excellent & 635.48 & 34.3 & 5.18 & 404.96 & 11.84 \\
\hline 225 & Norway maple & 50 & 12.6 & 213.6 & Excellent & 994.32 & 53.67 & 4.66 & 614.44 & 14.88 \\
\hline 226 & Sugar maple & 26.9 & 11 & 95.1 & Poor & 261.86 & 15.77 & 2.75 & 183.77 & 6.44 \\
\hline 227 & Red pine & 37.1 & 9.2 & 71 & Fair & 194.43 & 28.59 & 2.74 & 238.03 & 7.51 \\
\hline 228 & Red pine & 39.1 & 9.8 & 63.5 & Poor & 311.2 & 45.76 & 4.9 & 274.24 & 6.09 \\
\hline 229 & Red pine & 38.1 & 12 & 71 & Poor & 303.11 & 44.57 & 4.27 & 258.85 & 5.89 \\
\hline 230 & Sugar maple & 45 & 14.6 & 103.7 & Critical & 288.44 & 17.38 & 2.78 & 598.9 & 6.9 \\
\hline 231 & Green ash & 25.9 & 15.8 & 153.7 & Excellent & 249.31 & 16.26 & 1.62 & 115.57 & 4.37 \\
\hline 232 & Norway maple & 45 & 12.6 & 19.6 & Excellent & 251.43 & 13.57 & 12.81 & 486.05 & 13.05 \\
\hline 233 & Norway maple & 58.9 & 15.2 & 165.3 & Excellent & 1058.07 & 57.11 & 6.4 & 906.38 & 18.58 \\
\hline 234 & Norway maple & 55.1 & 14.2 & 56.8 & Excellent & 625.99 & 33.79 & 11.02 & 774.29 & 16.99 \\
\hline 235 & Norway maple & 48 & 15 & 113.3 & Excellent & 608.1 & 32.82 & 5.37 & 578.14 & 14.45 \\
\hline 236 & Northern catalpa & 51.1 & 14.6 & 122.7 & Fair & 340 & 20.7 & 2.77 & 670.66 & 17.05 \\
\hline 237 & Honeylocust & 47 & 13.4 & 143.2 & Excellent & 137.63 & 14.41 & 0.96 & 546.64 & 15.11 \\
\hline 238 & Honeylocust & 7.9 & 5.7 & 16 & Excellent & 21.98 & 2.3 & 1.38 & 7.34 & 1.23 \\
\hline 239 & Honeylocust & 7.1 & 5 & 16 & Excellent & 22.37 & 2.34 & 1.4 & 5.7 & 1.07 \\
\hline 240 & Honeylocust & 7.1 & 4 & 12.5 & Excellent & 14.45 & 1.51 & 1.15 & 5.59 & 1.05 \\
\hline 241 & Honeylocust & 7.1 & 5 & 19.6 & Excellent & 30.06 & 3.15 & 1.53 & 5.7 & 1.07 \\
\hline 242 & Honeylocust & 7.1 & 6 & 12.5 & Excellent & 21.67 & 2.27 & 1.73 & 5.82 & 1.08 \\
\hline 243 & Honeylocust & 7.1 & 3.9 & 19.6 & Excellent & 21.52 & 2.25 & 1.1 & 5.58 & 1.05 \\
\hline 244 & Norway maple & 52.1 & 12 & 143.2 & Excellent & 462.91 & 24.98 & 3.23 & 665.72 & 15.54 \\
\hline 245 & Sugar maple & 53.1 & 11.4 & 176.6 & Excellent & 671.17 & 40.43 & 3.8 & 878.33 & 20.47 \\
\hline 246 & Green ash & 61 & 20 & 380.4 & Excellent & 1405.81 & 91.69 & 3.7 & 593.69 & 10.12 \\
\hline 247 & Honeylocust & 52.1 & 14.6 & 227.2 & Excellent & 336.01 & 35.18 & 1.48 & 703 & 17.53 \\
\hline 248 & Norway maple & 64 & 15 & 133 & Excellent & 545.92 & 29.47 & 4.1 & 1083.89 & 20.53 \\
\hline 249 & Honeylocust & 56.9 & 15.2 & 268.8 & Excellent & 376.38 & 39.41 & 1.4 & 871.7 & 19.91 \\
\hline 250 & Norway maple & 57.9 & 13.4 & 213.6 & Excellent & 1238.63 & 66.85 & 5.8 & 855.15 & 17.93 \\
\hline 251 & Austrian pine & 16 & 7.8 & 23.6 & Excellent & 155.19 & 14.96 & 6.56 & 26 & 1.47 \\
\hline 252 & Honeylocust & 48 & 14.8 & 213.6 & Excellent & 405.76 & 42.49 & 1.9 & 579.6 & 15.66 \\
\hline 253 & Norway maple & 41.9 & 11.6 & 165.3 & Excellent & 512.5 & 27.66 & 3.1 & 411.35 & 11.86 \\
\hline 254 & Red pine & 32 & 10.8 & 86.8 & Excellent & 330.64 & 48.62 & 3.81 & 181.34 & 6.22 \\
\hline 255 & Red pine & 37.1 & 8.4 & 33.1 & Critical & 109.53 & 16.11 & 3.31 & 233.04 & 3.14 \\
\hline 256 & Red pine & 46 & 13.2 & 103.7 & Poor & 347.91 & 51.16 & 3.35 & 390.52 & 7.49 \\
\hline 257 & Norway maple & 36.1 & 10.8 & 78.5 & Good & 529.2 & 28.56 & 6.74 & 292.65 & 9.79 \\
\hline 258 & Red pine & 37.1 & 12.2 & 28.3 & Fair & 130.6 & 19.21 & 4.61 & 234.28 & 7.51 \\
\hline 259 & Red pine & 47 & 9.2 & 50.1 & Dying & 197.53 & 29.05 & 3.94 & 400.61 & 1.51 \\
\hline 260 & Red pine & 34 & 15 & 38.6 & Critical & 196.37 & 28.88 & 5.09 & 197.86 & 2.81 \\
\hline
\end{tabular}




\begin{tabular}{|c|c|c|c|c|c|c|c|c|c|c|}
\hline 261 & Norway maple & 41.9 & 12.9 & 113.3 & Excellent & 492.99 & 26.61 & 4.35 & 418.69 & 12.02 \\
\hline 262 & Red pine & 32 & 15 & 38.6 & Excellent & 131.53 & 19.34 & 3.41 & 169.62 & 6.22 \\
\hline 263 & Red pine & 40.9 & 17 & 56.8 & Poor & 193.54 & 28.46 & 3.41 & 294.65 & 6.45 \\
\hline 264 & Norway maple & 62 & 15.8 & 133 & Excellent & 545.5 & 29.44 & 4.1 & 1018.38 & 19.86 \\
\hline 265 & Norway maple & 46 & 10.2 & 122.7 & Fair & 415.19 & 22.41 & 3.38 & 494.27 & 13.11 \\
\hline 266 & Norway maple & 49 & 12 & 103.7 & Excellent & 554.6 & 29.93 & 5.35 & 583.09 & 14.43 \\
\hline 267 & Norway maple & 48 & 15 & 122.7 & Excellent & 870.86 & 47 & 7.1 & 578.14 & 14.45 \\
\hline 268 & Norway maple & 72.9 & 15.4 & 240.4 & Excellent & 1394.35 & 75.26 & 5.8 & 1448.03 & 24.17 \\
\hline 269 & Red pine & 51.1 & 12 & 95.1 & Poor & 464.87 & 68.36 & 4.89 & 497.42 & 8.56 \\
\hline 270 & Norway maple & 59.9 & 15 & 176.6 & Excellent & 1130.4 & 61.01 & 6.4 & 938.75 & 18.95 \\
\hline 271 & Norway maple & 48 & 9 & 189 & Excellent & 601.33 & 32.46 & 3.18 & 534.59 & 13.66 \\
\hline 272 & Northern catalpa & 69.1 & 15.4 & 165.3 & Excellent & 562.1 & 34.22 & 3.4 & 1388.94 & 26.19 \\
\hline 273 & Norway maple & 64 & 17 & 213.6 & Excellent & 1452.19 & 78.38 & 6.8 & 1106.57 & 20.84 \\
\hline 274 & Green ash & 38.1 & 12.6 & 133 & Excellent & 339 & 22.11 & 2.55 & 182.66 & 4.99 \\
\hline 275 & Sugar maple & 65 & 17.2 & 189 & Excellent & 1020.82 & 61.5 & 5.4 & 1401.66 & 26.64 \\
\hline 276 & Littleleaf linden & 53.1 & 14.8 & 153.7 & Excellent & 1045.33 & 78.3 & 6.8 & 468.64 & 11.18 \\
\hline 277 & Norway maple & 67.1 & 17.8 & 213.6 & Excellent & 1452.19 & 78.38 & 6.8 & 1234.49 & 22.19 \\
\hline 278 & Red pine & 30 & 9 & 28.3 & Fair & 79.13 & 11.64 & 2.79 & 144.03 & 5.73 \\
\hline 279 & Horsechestnut & 65 & 17 & 189 & Excellent & 1285.48 & 89.89 & 6.8 & 1209.42 & 24.16 \\
\hline 280 & Red pine & 36.1 & 11 & 71 & Excellent & 291.65 & 42.89 & 4.11 & 229.83 & 7.25 \\
\hline 281 & Red pine & 39.1 & 13 & 78.5 & Excellent & 311.57 & 45.82 & 3.97 & 274.26 & 8.04 \\
\hline 282 & Black ash & 45 & 17 & 113.3 & Excellent & 449.58 & 26.76 & 3.97 & 389.93 & 10.71 \\
\hline 283 & Northern catalpa & 37.1 & 13 & 50.1 & Excellent & 187.33 & 11.41 & 3.74 & 310.01 & 10.83 \\
\hline 284 & Eastern white pine & 15 & 8 & 19.6 & Excellent & 127.8 & 8.22 & 6.51 & 20.34 & 1.51 \\
\hline 285 & Littleleaf linden & 58.9 & 15 & 176.6 & Excellent & 1201.05 & 89.97 & 6.8 & 599.46 & 12.87 \\
\hline 286 & Black ash & 41.9 & 14 & 78.5 & Excellent & 494.39 & 29.43 & 6.3 & 331.84 & 9.78 \\
\hline 287 & Norway maple & 46 & 13.6 & 122.7 & Critical & 582.62 & 31.45 & 4.75 & 517.07 & 5.66 \\
\hline 288 & Eastern white pine & 22.1 & 12.4 & 50.1 & Excellent & 458.51 & 29.49 & 9.15 & 55.5 & 2.6 \\
\hline 289 & Green ash & 59.9 & 18.8 & 201.1 & Excellent & 820.74 & 53.53 & 4.08 & 548.18 & 9.56 \\
\hline 290 & Bur oak & 15 & 8.5 & 14.1 & Excellent & 68.56 & 6.77 & 4.86 & 32.37 & 2.95 \\
\hline 291 & Eastern white pine & 15 & 5.9 & 11 & Excellent & 56.13 & 3.61 & 5.08 & 18.49 & 1.51 \\
\hline 292 & Bur oak & 17 & 6.1 & 16 & Excellent & 60.7 & 5.99 & 3.8 & 44.45 & 3.55 \\
\hline 294 & $\begin{array}{l}\text { London plane } \\
\text { Kentucky }\end{array}$ & 50 & 13.4 & 95.1 & Excellent & 666.53 & 30.62 & 7.01 & 635.29 & 16.51 \\
\hline 295 & coffeetree & 71.9 & 26 & 397.4 & Fair & 1624.2 & 121.62 & 4.09 & 1592.41 & 28.55 \\
\hline 296 & Littleleaf linden & 70.1 & 17 & 201.1 & Excellent & 1011.79 & 75.79 & 5.03 & 902.83 & 16.28 \\
\hline 297 & Norway maple & 71.1 & 17.2 & 314 & Excellent & 2009.59 & 108.46 & 6.4 & 1395.68 & 23.74 \\
\hline
\end{tabular}




\begin{tabular}{|c|c|c|c|c|c|c|c|c|c|c|}
\hline 298 & Norway maple & 55.9 & 21 & 283.2 & Excellent & 1467.26 & 79.19 & 5.18 & 857.97 & 18.22 \\
\hline 299 & Norway maple & 40.9 & 6 & 78.5 & Excellent & 271.99 & 14.68 & 3.46 & 357.31 & 10.82 \\
\hline 300 & Horsechestnut & 65 & 16.4 & 143.2 & Excellent & 501.86 & 35.1 & 3.5 & 1206.25 & 24.11 \\
\hline 301 & London plane & 48 & 18.8 & 176.6 & Fair & 973.86 & 44.73 & 5.51 & 591.6 & 15.89 \\
\hline 302 & Norway maple & 56.9 & 21 & 298.9 & Good & 2121.97 & 114.53 & 7.1 & 891.95 & 18.62 \\
\hline 303 & Norway maple & 49 & 18.9 & 189 & Fair & 988.87 & 53.37 & 5.23 & 632.64 & 15.32 \\
\hline 304 & London plane & 52.1 & 17.6 & 165.3 & Excellent & 870.22 & 39.97 & 5.26 & 713.44 & 17.72 \\
\hline 305 & London plane & 64 & 15.6 & 227.2 & Poor & 1544.89 & 70.96 & 6.8 & 1157.6 & 17.85 \\
\hline 306 & Green ash & 9.9 & 6.6 & 16 & Poor & 55.97 & 3.65 & 3.5 & 11.06 & 0.83 \\
\hline 307 & Red Ash & 8.9 & 6.8 & 19.6 & Excellent & 50.4 & 3.77 & 2.57 & 11.46 & 1.47 \\
\hline 308 & Red Ash & 7.9 & 11.3 & 3.2 & Excellent & 18.11 & 1.36 & 5.7 & 8.6 & 1.32 \\
\hline 309 & Red Ash & 9.9 & 8.2 & 4.9 & Dying & 22.01 & 1.65 & 4.49 & 13.76 & 0.25 \\
\hline 310 & Red Ash & 11.4 & 10.9 & 16 & Critical & 87.89 & 6.58 & 5.5 & 21.62 & 0.88 \\
\hline 311 & Boxelder & 26.9 & 15.2 & 86.8 & Critical & 408.27 & 37.35 & 4.7 & 166.76 & 3.03 \\
\hline 312 & Boxelder & 15.5 & 10.6 & 38.6 & Excellent & 183.7 & 16.8 & 4.76 & 46.91 & 3.57 \\
\hline 313 & Boxelder & 6.1 & 5.5 & 4.9 & Excellent & 14.73 & 1.35 & 3 & 5.51 & 1.09 \\
\hline 314 & Black walnut & 8.9 & 8.7 & 7 & Fair & 64.84 & 5.2 & 9.25 & 10.25 & 1.5 \\
\hline 315 & Red Ash & 9.9 & 7.6 & 23.6 & Fair & 91.32 & 6.84 & 3.86 & 15.72 & 1.71 \\
\hline 316 & Red Ash & 9.9 & 7.3 & 16 & Fair & 59.24 & 4.44 & 3.71 & 14.71 & 1.71 \\
\hline 317 & Red Ash & 47 & 16.5 & 176.6 & Excellent & 900.79 & 67.45 & 5.1 & 582.62 & 15.29 \\
\hline 318 & Black walnut & 14 & 10.8 & 50.1 & Poor & 463.62 & 37.16 & 9.26 & 30.29 & 2.11 \\
\hline 319 & Black walnut & 19.1 & 14.9 & 50.1 & Excellent & 476.07 & 38.15 & 9.5 & 65.23 & 4.39 \\
\hline 320 & Red Ash & 16 & 8.1 & 23.6 & Excellent & 115.96 & 8.68 & 4.9 & 43.94 & 3.29 \\
\hline 321 & Red Ash & 14 & 7.9 & 12.5 & Excellent & 59.21 & 4.43 & 4.73 & 31.07 & 2.73 \\
\hline 322 & Black walnut & 14 & 11.9 & 50.1 & Dying & 626.49 & 50.21 & 12.51 & 30.66 & 0.41 \\
\hline 323 & Red Ash & 8.9 & 6.7 & 14.1 & Excellent & 56.41 & 4.22 & 4 & 11.62 & 1.47 \\
\hline 324 & Norway maple & 37.1 & 14.4 & 122.7 & Dying & 491.95 & 26.55 & 4.01 & 327.95 & 1.57 \\
\hline 325 & Red Ash & 7.9 & 6.4 & 12.5 & Fair & 52.93 & 3.96 & 4.23 & 9.02 & 1.24 \\
\hline 326 & Siberian elm & 6.1 & 10.2 & 12.5 & Fair & 122.18 & 8.32 & 9.76 & 3.39 & 0.76 \\
\hline 327 & Green ash & 36.1 & 14 & 113.3 & Poor & 459.95 & 30 & 4.06 & 181.72 & 3.9 \\
\hline 328 & Black walnut & 6.1 & 7.1 & 12.5 & Poor & 87.14 & 6.98 & 6.96 & 4.15 & 0.67 \\
\hline 329 & Red Ash & 8.9 & 14.4 & 11 & Excellent & 15.84 & 1.19 & 1.43 & 11.59 & 1.6 \\
\hline 330 & Red Ash & 8.9 & 11.7 & 12.5 & Excellent & 23.15 & 1.73 & 1.85 & 11.41 & 1.55 \\
\hline 331 & Red Ash & 7.9 & 10.8 & 9.6 & Critical & 20.5 & 1.54 & 2.12 & 8.61 & 0.54 \\
\hline 332 & Boxelder & 7.9 & 12.3 & 12.5 & Critical & 32.71 & 2.99 & 2.61 & 11.95 & 0.72 \\
\hline 333 & Red Ash & 7.1 & 8 & 7 & Excellent & 19.34 & 1.45 & 2.76 & 6.61 & 1.11 \\
\hline 334 & Green ash & 13 & 10 & 28.3 & Fair & 67.16 & 4.38 & 2.37 & 24.56 & 1.84 \\
\hline
\end{tabular}




\begin{tabular}{|c|c|c|c|}
\hline 335 & Red Ash & 7.9 & 10.3 \\
\hline 336 & Red Ash & 7.9 & 10.3 \\
\hline 337 & Bur oak & 10.6 & 9 \\
\hline 338 & Green ash & 10.9 & 10.2 \\
\hline 339 & Red Ash & 11.9 & 9.4 \\
\hline 340 & Black walnut & 12 & 6 \\
\hline 341 & Red Ash & 11.1 & 11 \\
\hline 342 & Boxelder & 11.9 & 9.3 \\
\hline 343 & Red Ash & 7.9 & 6.7 \\
\hline 344 & Norway maple & 39.1 & 14.8 \\
\hline 345 & Norway maple & 23.6 & 14.8 \\
\hline 346 & Siberian elm & 11.9 & 9.1 \\
\hline 347 & Red Ash & 7.1 & 7 \\
\hline 348 & Siberian elm & 15 & 10.7 \\
\hline 349 & Siberian elm & 18 & 10.5 \\
\hline 350 & Siberian elm & 16 & 10.8 \\
\hline 351 & Norway maple & 7.9 & 7 \\
\hline 352 & Norway maple & 8.9 & 6.5 \\
\hline 353 & Boxelder & 20.9 & 9.8 \\
\hline 354 & Green ash & 7.9 & 9.5 \\
\hline 355 & Eastern white pine & 17 & 10 \\
\hline 356 & Black ash & 7.9 & 8.3 \\
\hline 357 & Swamp white oak & 105.9 & 30 \\
\hline 358 & Red pine & 25.9 & 13.4 \\
\hline 359 & Red pine & 25.9 & 13.2 \\
\hline 360 & Red pine & 26.9 & 12.2 \\
\hline 361 & Red pine & 38.1 & 15.2 \\
\hline 362 & Red pine & 42.9 & 15.6 \\
\hline 363 & Red pine & 26.9 & 12.4 \\
\hline 364 & Northern red oak & 11.9 & 7.4 \\
\hline 365 & Freeman maple & 9.9 & 7.3 \\
\hline 366 & Northern red oak & 9.9 & 7.7 \\
\hline 367 & Freeman maple & 10.9 & 9.3 \\
\hline 368 & Freeman maple & 13 & 9.1 \\
\hline 369 & Eastern white pine & 7.1 & 4.8 \\
\hline 370 & Eastern white pine & 8.9 & 4.8 \\
\hline 371 & Eastern white pine & 9.9 & 6 \\
\hline
\end{tabular}

$\begin{aligned} 11 & \text { Poor } \\ 9.6 & \text { Poor } \\ 14.1 & \text { Dying } \\ 23.6 & \text { Dying } \\ 16 & \text { Critical } \\ 12.5 & \text { Poor } \\ 17.8 & \text { Poor } \\ 38.6 & \text { Poor } \\ 23.6 & \text { Excellent } \\ 78.5 & \text { Excellent } \\ 44.2 & \text { Excellent } \\ 33.1 & \text { Excellent } \\ 5.9 & \text { Poor } \\ 23.6 & \text { Poor } \\ 24.2 & \text { Excellent } \\ 17.3 & \text { Excellent } \\ 8.4 & \text { Fair } \\ 10.2 & \text { Excellent } \\ 41.3 & \text { Poor } \\ 4 & \text { Critical } \\ 12.5 & \text { Excellent } \\ 11 & \text { Fair } \\ 490.6 & \text { Excellent } \\ 30.7 & \text { Fair } \\ 38.6 & \text { Fair } \\ 33.1 & \text { Critical } \\ 78.5 & \text { Critical } \\ 71 & \text { Poor } \\ 28.3 & \text { Poor } \\ 22.1 & \text { Poor } \\ 18.4 & \text { Excellent } \\ 15.1 & \text { Excellent } \\ 9.6 & \text { Excellent } \\ 12 & \text { Excellent } \\ 5.9 & \text { Excellent } \\ 7 & \text { Excellent } \\ 7.6 & \text { Excellent }\end{aligned}$

$\begin{array}{rrr}26.5 & 1.98 & 2.4 \\ 20.5 & 1.54 & 2.12 \\ 25.67 & 2.53 & 1.82 \\ 49.62 & 3.24 & 2.1 \\ 27.34 & 2.05 & 1.71 \\ 46.39 & 3.72 & 3.7 \\ 48.99 & 3.67 & 2.76 \\ 77.66 & 7.1 & 2.01 \\ 65.23 & 4.88 & 2.76 \\ 209.97 & 11.33 & 2.67 \\ 369.3 & 19.93 & 8.36 \\ 207.9 & 14.16 & 6.28 \\ 16.31 & 1.22 & 2.76 \\ 69 & 4.7 & 2.92 \\ 128.5 & 8.75 & 5.32 \\ 117.31 & 7.99 & 6.78 \\ 27.25 & 1.47 & 3.26 \\ 33.14 & 1.79 & 3.26 \\ 124.12 & 11.35 & 3 \\ 17.18 & 1.12 & 4.3 \\ 75.82 & 4.88 & 6.05 \\ 45.79 & 2.73 & 4.15 \\ 1864.37 & 183.99 & 3.8 \\ 146.51 & 21.55 & 4.78 \\ 221.41 & 32.56 & 5.74 \\ 149.85 & 22.04 & 4.53 \\ 301.13 & 44.28 & 3.84 \\ 317.42 & 46.68 & 4.47 \\ 144.91 & 21.31 & 5.12 \\ 79.66 & 6.35 & 3.61 \\ 126.11 & 7.1 & 6.84 \\ 78.12 & 6.22 & 5.16 \\ 81.81 & 8.48 \\ 87.43 & & 7.31 \\ 29.26 & 4.95 \\ 28.79 & 4.11 \\ 40.94 & 5.39\end{array}$

\begin{tabular}{|c|c|}
\hline 8.73 & 0.98 \\
\hline 8.55 & 0.98 \\
\hline 13.69 & 0.26 \\
\hline 18.76 & 0.24 \\
\hline 21.43 & 0.92 \\
\hline 20.12 & 1.65 \\
\hline 19.34 & 1.56 \\
\hline 26.19 & 1.95 \\
\hline 9.43 & 1.25 \\
\hline 369.89 & 11.27 \\
\hline 125.42 & 6.22 \\
\hline 17.02 & 1.88 \\
\hline 6.41 & 0.82 \\
\hline 29.36 & 1.94 \\
\hline 45.78 & 3.32 \\
\hline 34.37 & 2.81 \\
\hline 10.09 & 1.53 \\
\hline 12.82 & 1.73 \\
\hline 87.66 & 3.79 \\
\hline 10.2 & 0.51 \\
\hline 25.15 & 1.8 \\
\hline 7.12 & 1.16 \\
\hline 4925.81 & 47.54 \\
\hline 108.56 & 4.76 \\
\hline 112.97 & 4.76 \\
\hline 117.93 & 2.08 \\
\hline 258.73 & 3.25 \\
\hline 335.1 & 6.86 \\
\hline 117.64 & 3.79 \\
\hline 21.58 & 1.82 \\
\hline 16.61 & 2 \\
\hline 13.72 & 1.86 \\
\hline 21.69 & 2.34 \\
\hline 31.03 & 2.83 \\
\hline 3.55 & 0.54 \\
\hline 5.55 & 0.73 \\
\hline 7.3 & 0.85 \\
\hline
\end{tabular}




\begin{tabular}{|c|c|c|c|}
\hline 372 & Northern red oak & 9.9 & 5.7 \\
\hline 373 & Northern red oak & 10.9 & 6.3 \\
\hline 374 & $\begin{array}{l}\text { Kentucky } \\
\text { coffeetree }\end{array}$ & 8.9 & 78 \\
\hline 375 & Norway maple & 9.9 & 3.4 \\
\hline 376 & Freeman maple & 13 & 10.5 \\
\hline 377 & Freeman maple & 20.1 & 12.9 \\
\hline 378 & Northern red oak & 13 & 8.2 \\
\hline 379 & Northern red oak & 11.9 & 6.9 \\
\hline 380 & Freeman maple & 11.9 & 9 \\
\hline 381 & Silver maple & 9.9 & 8.8 \\
\hline 382 & Freeman maple & 18 & 13.8 \\
\hline 383 & Freeman maple & 17 & 12.7 \\
\hline 384 & Silver maple & 11.9 & 9 \\
\hline 385 & Silver maple & 12.7 & 8 \\
\hline 386 & Eastern white pine & 11.9 & 6.5 \\
\hline 387 & Freeman maple & 20.7 & 9.7 \\
\hline 388 & Sugar maple & 6.1 & 5.7 \\
\hline 389 & Northern red oak & 10.9 & 5.8 \\
\hline 390 & Freeman maple & 7.1 & 4.8 \\
\hline 391 & Boxelder & 13 & 8.6 \\
\hline 392 & Eastern white pine & 15 & 6.9 \\
\hline 393 & Boxelder & 11.9 & 4 \\
\hline 394 & Northern red oak & 9.9 & 4.1 \\
\hline 395 & Silver maple & 8.9 & 9.7 \\
\hline 396 & Bur oak & 7.9 & 5.8 \\
\hline 397 & Silver maple & 12.6 & 9.8 \\
\hline 398 & Silver maple & 11.2 & 6.7 \\
\hline 399 & Northern red oak & 11.9 & 7.3 \\
\hline 400 & Red Ash & 9.9 & 7.4 \\
\hline & Kentucky & & \\
\hline 401 & coffeetree & 10.9 & 7.8 \\
\hline 402 & Freeman maple & 13 & 9.9 \\
\hline 403 & Red Ash & 7.9 & 8.2 \\
\hline 404 & Sugar maple & 6.6 & 6.4 \\
\hline 405 & Freeman maple & 15 & 13 \\
\hline 406 & Bur oak & 9.9 & 5.6 \\
\hline
\end{tabular}

$\begin{aligned} 11.6 & \text { Excellent } \\ 12 & \text { Excellent } \\ & \\ 13.5 & \text { Excellent } \\ 4.1 & \text { Excellent } \\ 15.1 & \text { Excellent } \\ 29.2 & \text { Excellent } \\ 22.6 & \text { Excellent } \\ 15.6 & \text { Excellent } \\ 18.9 & \text { Excellent } \\ 16.6 & \text { Excellent } \\ 32.8 & \text { Excellent } \\ 25 & \text { Excellent } \\ 11.6 & \text { Excellent } \\ 24.7 & \text { Excellent } \\ 11.6 & \text { Fair } \\ 45.2 & \text { Excellent } \\ 5.8 & \text { Excellent } \\ 11.6 & \text { Excellent } \\ 10.2 & \text { Excellent } \\ 31.3 & \text { Excellent } \\ 16 & \text { Excellent } \\ 24.7 & \text { Excellent } \\ 13.9 & \text { Excellent } \\ 13.3 & \text { Excellent } \\ 8.8 & \text { Excellent } \\ 15.1 & \text { Excellent } \\ 12 & \text { Excellent } \\ 15.1 & \text { Excellent } \\ 12 & \text { Excellent } \\ 10.5 & \text { Excellent } \\ & \text { Excellent } \\ 12.9 & \text { Excellent } \\ 14.9 & \text { Excellent } \\ & \end{aligned}$

\begin{tabular}{|c|c|c|}
\hline 39.82 & 3.17 & 3.44 \\
\hline 53.47 & 4.26 & 4.47 \\
\hline 89.56 & 6.71 & 6.64 \\
\hline 21.03 & 1.14 & 5.12 \\
\hline 154.02 & 8.67 & 10.18 \\
\hline 368.58 & 20.74 & 12.63 \\
\hline 89.27 & 7.11 & 3.95 \\
\hline 54.65 & 4.35 & 3.51 \\
\hline 103.96 & 5.85 & 5.5 \\
\hline 73.83 & 3.89 & 4.44 \\
\hline 231.12 & 13.01 & 7.05 \\
\hline 182.37 & 10.26 & 7.3 \\
\hline 62.43 & 3.29 & 5.39 \\
\hline 111.45 & 5.87 & 4.51 \\
\hline 61.77 & 3.97 & 5.33 \\
\hline 234.58 & 13.2 & 5.19 \\
\hline 14.31 & 0.86 & 2.48 \\
\hline 31.7 & 2.53 & 2.74 \\
\hline 36.87 & 2.08 & 3.63 \\
\hline 114.59 & 10.48 & 3.66 \\
\hline 67.18 & 4.32 & 4.2 \\
\hline 88.76 & 8.12 & 3.59 \\
\hline 37.89 & 3.02 & 2.73 \\
\hline 77.86 & 4.1 & 5.85 \\
\hline 26.16 & 2.58 & 2.96 \\
\hline 65.2 & 3.43 & 4.31 \\
\hline 55.3 & 2.91 & 4.63 \\
\hline 38.66 & 3.08 & 2.55 \\
\hline 63.52 & 4.76 & 5.31 \\
\hline 82.2 & 6.15 & 6.37 \\
\hline 137.39 & 7.73 & 9.21 \\
\hline 45.64 & 3.42 & 6.01 \\
\hline 24.55 & 1.48 & 3.81 \\
\hline 143.43 & 8.07 & 10.63 \\
\hline 32.83 & 3.24 & 3.23 \\
\hline
\end{tabular}

\begin{tabular}{|c|c|}
\hline 13.72 & 1.86 \\
\hline 17.39 & 2.14 \\
\hline 10.11 & 1.49 \\
\hline 14.39 & 1.8 \\
\hline 32.12 & 2.91 \\
\hline 85.65 & 5.01 \\
\hline 26.32 & 2.71 \\
\hline 21.58 & 2.42 \\
\hline 25.97 & 2.57 \\
\hline 21.81 & 2.15 \\
\hline 69.52 & 4.49 \\
\hline 60.2 & 4.13 \\
\hline 30.44 & 2.5 \\
\hline 30.56 & 2.39 \\
\hline 11.41 & 1.1 \\
\hline 85.68 & 4.94 \\
\hline 6 & 1.28 \\
\hline 17.39 & 2.14 \\
\hline 7.43 & 1.27 \\
\hline 30.58 & 2.8 \\
\hline 18.78 & 1.51 \\
\hline 22.19 & 2.29 \\
\hline 13.72 & 1.86 \\
\hline 19.69 & 2.14 \\
\hline 6.51 & 1.16 \\
\hline 35.79 & 2.79 \\
\hline 21.32 & 1.9 \\
\hline 21.58 & 2.42 \\
\hline 14.85 & 1.71 \\
\hline 16.38 & 1.96 \\
\hline 31.65 & 2.88 \\
\hline 9.04 & 1.27 \\
\hline 7.21 & 1.41 \\
\hline 46.31 & 3.59 \\
\hline 11.54 & 1.61 \\
\hline
\end{tabular}




\begin{tabular}{|c|c|c|c|c|c|c|c|c|c|c|}
\hline 407 & Northern red oak & 9.9 & 5.7 & 12.5 & Excellent & 47.1 & 3.75 & 3.76 & 13.72 & 1.86 \\
\hline 408 & Tree of heaven & 13 & 6.6 & 33.1 & Excellent & 186.02 & 13.93 & 5.62 & 24.1 & 2.44 \\
\hline 409 & Northern red oak & 10.9 & 4.9 & 5.8 & Excellent & 19.7 & 1.57 & 3.41 & 17.39 & 2.14 \\
\hline 410 & Freeman maple & 7.9 & 5.3 & 12.5 & Excellent & 60.13 & 3.38 & 4.8 & 9.45 & 1.45 \\
\hline 411 & Freeman maple & 8.9 & 7.7 & 9.6 & Excellent & 81.28 & 4.57 & 8.42 & 13.37 & 1.78 \\
\hline 412 & Freeman maple & 15 & 10.2 & 16 & Excellent & 127.86 & 7.2 & 8 & 43.47 & 3.42 \\
\hline 413 & Red Ash & 6.1 & 2.6 & 7 & Excellent & 17.58 & 1.32 & 2.51 & 4.29 & 0.84 \\
\hline 414 & Freeman maple & 7.1 & 5.3 & 5.8 & Excellent & 25.58 & 1.44 & 4.43 & 7.59 & 1.29 \\
\hline 415 & Boxelder & 6.1 & 4.7 & 4.6 & Excellent & 16.61 & 1.52 & 3.65 & 5.31 & 1.06 \\
\hline 416 & Eastern white pine & 13 & 6.6 & 14.1 & Excellent & 50.83 & 3.27 & 3.61 & 13.28 & 1.23 \\
\hline 417 & Norway maple & 6.1 & 6.6 & 2.4 & Excellent & 10.64 & 0.57 & 4.49 & 5.79 & 1.13 \\
\hline 418 & Eastern white pine & 13 & 5.8 & 15.6 & Excellent & 56.32 & 3.62 & 3.62 & 13.43 & 1.23 \\
\hline 419 & Boxelder & 15 & 7.4 & 23.6 & Excellent & 115.18 & 10.54 & 4.87 & 40.5 & 3.24 \\
\hline 420 & Eastern white pine & 8.9 & 6.3 & 11 & Excellent & 55.08 & 3.54 & 4.99 & 6.23 & 0.73 \\
\hline 421 & Northern red oak & 12.5 & 5.8 & 22.6 & Excellent & 77.24 & 6.15 & 3.42 & 24.17 & 2.58 \\
\hline 422 & $\begin{array}{l}\text { Northern red oak } \\
\text { Kentucky }\end{array}$ & 9.9 & 4.9 & 20.1 & Fair & 60.99 & 4.86 & 3.03 & 13.72 & 1.86 \\
\hline 423 & coffeetree & 8.9 & 6.5 & 8.5 & Good & 36.49 & 2.73 & 4.29 & 9.9 & 1.46 \\
\hline 424 & Wych elm & 23.9 & 7.1 & 31.6 & Excellent & 229.55 & 15.63 & 7.27 & 89.74 & 4.88 \\
\hline 425 & Freeman maple & 8.9 & 3.8 & 4.3 & Poor & 16.59 & 0.93 & 3.84 & 11.54 & 1.2 \\
\hline 426 & Freeman maple & 7.1 & 4.9 & 3.8 & Poor & 17.79 & 1 & 4.7 & 7.47 & 0.96 \\
\hline 427 & Bur oak & 8.9 & 4.6 & 5.9 & Excellent & 22.62 & 2.23 & 3.83 & 8.81 & 1.38 \\
\hline 428 & Northern red oak & 8.9 & 4.6 & 10.2 & Fair & 32.68 & 2.6 & 3.22 & 10.55 & 1.6 \\
\hline 429 & Freeman maple & 8.9 & 5 & 5.5 & Fair & 27.28 & 1.54 & 4.94 & 12.12 & 1.66 \\
\hline 430 & $\begin{array}{l}\text { Northern red oak } \\
\text { Kentucky }\end{array}$ & 8.9 & 5 & 15.6 & Fair & 49.36 & 3.93 & 3.17 & 10.55 & 1.6 \\
\hline 431 & coffeetree & 8.9 & 6.6 & 8.8 & Excellent & 48.01 & 3.59 & 5.44 & 9.92 & 1.47 \\
\hline 432 & Freeman maple & 7.9 & 6.5 & 9.6 & Excellent & 47.76 & 2.69 & 4.95 & 9.9 & 1.5 \\
\hline 433 & Eastern white pine & 14 & 6.5 & 12.9 & Excellent & 63.57 & 4.09 & 4.93 & 16.02 & 1.37 \\
\hline 434 & Eastern white pine & 10.9 & 6.5 & 8.4 & Excellent & 36.65 & 2.36 & 4.39 & 8.86 & 0.97 \\
\hline 435 & serviceberry spp & 8.9 & 6.9 & 7.6 & Excellent & 32.37 & 2.45 & 4.26 & 9.89 & 1.46 \\
\hline 436 & serviceberry spp & 7.3 & 6.9 & 7.6 & Excellent & 32.37 & 2.45 & 4.26 & 6.34 & 1.14 \\
\hline 437 & Green ash & 6.1 & 4.5 & 7.3 & Excellent & 22.73 & 1.48 & 3.11 & 3.54 & 0.58 \\
\hline 438 & Northern red oak & 8.9 & 4.4 & 8 & Excellent & 24.28 & 1.93 & 3.02 & 10.55 & 1.6 \\
\hline 439 & Green ash & 10.6 & 7.3 & 16 & Excellent & 98.92 & 6.45 & 6.19 & 13.51 & 1.25 \\
\hline 440 & Northern red oak & 8.9 & 4.9 & 9.6 & Fair & 31.57 & 2.52 & 3.27 & 10.55 & 1.6 \\
\hline 441 & Kentucky & 9.9 & 6.4 & 12 & Excellent & 65.66 & 4.92 & 5.49 & 12.75 & 1.69 \\
\hline
\end{tabular}


coffeetree

\begin{tabular}{|c|c|c|c|}
\hline 442 & Green ash & 8.9 & 6.8 \\
\hline 443 & Freeman maple & 11.9 & 8.4 \\
\hline 444 & Freeman maple & 13 & 8.2 \\
\hline 445 & Freeman maple & 11.4 & 5.7 \\
\hline 446 & Red Ash & 8.9 & 5.8 \\
\hline 447 & serviceberry spp & 7.9 & 5.6 \\
\hline 448 & Green ash & 8.9 & 6.4 \\
\hline 449 & Eastern white pine & 7.1 & 3.6 \\
\hline 450 & Green ash & 7.9 & 4.7 \\
\hline 451 & Wych elm & 8.9 & 6.1 \\
\hline 452 & Paper birch & 7.1 & 4.7 \\
\hline 453 & Eastern white pine & 8.9 & 3.6 \\
\hline 454 & Eastern white pine & 7.9 & 3.2 \\
\hline 455 & Green ash & 7.9 & 6.9 \\
\hline 456 & Black ash & 7.9 & 7 \\
\hline 457 & Green ash & 8.9 & 8.5 \\
\hline 458 & Red Ash & 7.9 & 7.1 \\
\hline 459 & Boxelder & 7.9 & 5.1 \\
\hline 460 & Littleleaf linden & 10.6 & 5.1 \\
\hline 461 & $\begin{array}{l}\text { Sugar maple } \\
\text { American }\end{array}$ & 7.1 & 5.2 \\
\hline 462 & basswood & 11.9 & 7 \\
\hline 463 & Boxelder & 14 & 7 \\
\hline 464 & Green ash & 10.9 & 7.5 \\
\hline 465 & Green ash & 8.9 & 7.5 \\
\hline 466 & Black walnut & 14 & 9.8 \\
\hline 467 & $\begin{array}{l}\text { Northern red oak } \\
\text { Kentucky }\end{array}$ & 6.1 & 6.6 \\
\hline 468 & coffeetree & 8.9 & 6.5 \\
\hline 469 & Black walnut & 7.1 & 4 \\
\hline 470 & Northern red oak & 7.9 & 4.7 \\
\hline 471 & Bur oak & 8.9 & 6.8 \\
\hline 472 & Eastern white pine & 10.9 & 5.2 \\
\hline 473 & Northern red oak & 7.9 & 6.4 \\
\hline 474 & Black walnut & 16 & 12.7 \\
\hline 475 & Eastern white pine & 9.9 & 6.2 \\
\hline
\end{tabular}

$\begin{aligned} 5.1 & \text { Excellent } \\ 12 & \text { Excellent } \\ 12.9 & \text { Excellent } \\ 12.9 & \text { Excellent } \\ 9.6 & \text { Excellent } \\ 8.5 & \text { Excellent } \\ 9.2 & \text { Excellent } \\ 3.2 & \text { Excellent } \\ 6.9 & \text { Excellent } \\ 9.8 & \text { Fair } \\ 6.6 & \text { Excellent } \\ 2.1 & \text { Fair } \\ 2.5 & \text { Fair } \\ 4.3 & \text { Excellent } \\ 5.1 & \text { Excellent } \\ 11 & \text { Excellent } \\ 11.6 & \text { Excellent } \\ 11 & \text { Excellent } \\ 6.9 & \text { Good } \\ 7.3 & \text { Excellent } \\ & \\ 9.6 & \text { Excellent } \\ 16.6 & \text { Excellent } \\ 13.9 & \text { Excellent } \\ 13.9 & \text { Excellent } \\ 20.1 & \text { Excellent } \\ 7.7 & \text { Excellent } \\ & \\ 12.9 & \text { Excellent } \\ 8.3 & \text { Excellent } \\ 6.9 & \text { Excellent } \\ 11.6 & \text { Excellent } \\ 11.4 & \text { Excellent } \\ 31.6 & \text { Excellent } \\ 4.7 & \text { Excellent }\end{aligned}$

\begin{tabular}{|c|c|c|}
\hline 31.67 & 2.07 & 6.15 \\
\hline 114.86 & 6.46 & 9.61 \\
\hline 113.85 & 6.41 & 8.82 \\
\hline 43.79 & 2.46 & 3.39 \\
\hline 49.17 & 3.68 & 5.1 \\
\hline 32.47 & 2.46 & 3.81 \\
\hline 51.31 & 3.35 & 5.61 \\
\hline 15.26 & 0.98 & 4.8 \\
\hline 29.14 & 1.9 & 4.24 \\
\hline 59.11 & 4.03 & 6.02 \\
\hline 27.25 & 1.91 & 4.14 \\
\hline 11.82 & 0.76 & 5.56 \\
\hline 12.24 & 0.79 & 4.82 \\
\hline 25.71 & 1.68 & 5.94 \\
\hline 29.91 & 1.78 & 5.81 \\
\hline 55.77 & 3.64 & 5.05 \\
\hline 31.96 & 2.39 & 2.76 \\
\hline 33.15 & 3.03 & 3 \\
\hline 26.57 & 1.99 & 3.87 \\
\hline 28.79 & 1.73 & 3.95 \\
\hline 31.48 & 0.92 & 3.26 \\
\hline 49.96 & 4.57 & 3 \\
\hline 37.88 & 2.47 & 2.73 \\
\hline 37.88 & 2.47 & 2.73 \\
\hline 169.99 & 13.62 & 8.45 \\
\hline 28.91 & 2.3 & 3.74 \\
\hline 59.51 & 4.46 & 4.61 \\
\hline 30.27 & 2.43 & 3.76 \\
\hline 24.49 & 1.95 & 3.36 \\
\hline 35.46 & 3.5 & 5.16 \\
\hline 28.42 & 1.83 & 2.45 \\
\hline 35.03 & 2.79 & 3.07 \\
\hline 574.29 & 46.03 & 18.19 \\
\hline 20.26 & 1.3 & 4.34 \\
\hline
\end{tabular}

$\begin{array}{rr}9.43 & 1.04 \\ 25.56 & 2.54 \\ 30.25 & 2.78 \\ 21.42 & 2.27 \\ 11.26 & 1.45 \\ 7.33 & 1.23 \\ 8.97 & 0.99 \\ 3.19 & 0.54 \\ 5.63 & 0.72 \\ 8.39 & 1.26 \\ 5.63 & 1.15 \\ 5.11 & 0.73 \\ 3.9 & 0.62 \\ 7.78 & 0.96 \\ 7.12 & 1.16 \\ 11.39 & 1.24 \\ 8.48 & 1.25 \\ 9.36 & 1.44 \\ 10.52 & 1.29 \\ 8.55 & 1.55 \\ & \\ 13.72 & 1.5 \\ 34.42 & 2.96 \\ 14.48 & 1.3 \\ 10.24 & 1.12 \\ 29.96 & 2.78 \\ 4.22 & 0.95 \\ 9.9 & 1.36 \\ 5.59 & 1.05 \\ 7.85 & 1.36 \\ 8.81 & 1.38 \\ 8.65 & 0.97 \\ 7.85 & \\ 42.49 & \\ 6.77 & \\ & \\ & \\ & \end{array}$




\begin{tabular}{|c|c|c|c|c|c|c|c|c|c|c|}
\hline 476 & Black walnut & 6.1 & 4.6 & 8 & Excellent & 42.15 & 3.38 & 5.24 & 3.94 & 0.86 \\
\hline 477 & Silver maple & 13.4 & 6.8 & 19.6 & Excellent & 85.34 & 4.49 & 4.35 & 29.23 & 2.21 \\
\hline 478 & Littleleaf linden & 7.9 & 5.9 & 6.4 & Excellent & 21.03 & 1.58 & 3.26 & 5.21 & 0.87 \\
\hline 479 & Littleleaf linden & 10.9 & 6.3 & 7.7 & Excellent & 46.19 & 3.46 & 5.97 & 11.26 & 1.34 \\
\hline 480 & Eastern white pine & 20.1 & 8.5 & 17.3 & Excellent & 136.32 & 8.77 & 7.88 & 38.1 & 2.27 \\
\hline 481 & Black walnut & 9.9 & 7.9 & 20.1 & Excellent & 113.91 & 9.13 & 5.67 & 13.04 & 1.72 \\
\hline 482 & Red Ash & 9.9 & 7 & 10.5 & Excellent & 36.11 & 2.7 & 3.44 & 13.95 & 1.7 \\
\hline 483 & Red Ash & 11.9 & 10.7 & 18.9 & Excellent & 106.22 & 7.95 & 5.62 & 24.14 & 2.27 \\
\hline 484 & Red Ash & 8.9 & 8.3 & 10.5 & Excellent & 38.34 & 2.87 & 3.65 & 11.34 & 1.49 \\
\hline 485 & Black walnut & 7.1 & 6.5 & 6.2 & Excellent & 27.55 & 2.21 & 4.46 & 5.87 & 1.09 \\
\hline 486 & Silver maple & 9.9 & 9.3 & 6.2 & Excellent & 24.67 & 1.3 & 3.99 & 22.83 & 2.24 \\
\hline 487 & Boxelder & 6.1 & 4.5 & 8.5 & Excellent & 18.14 & 1.66 & 2.13 & 5.27 & 1.06 \\
\hline 488 & Boxelder & 9.9 & 6.4 & 11.6 & Excellent & 30.34 & 2.78 & 2.62 & 16.11 & 1.95 \\
\hline 489 & Littleleaf linden & 7.1 & 7.4 & 5.9 & Excellent & 23.22 & 1.74 & 3.93 & 4.1 & 0.76 \\
\hline 490 & Green ash & 14 & 8.1 & 15.1 & Excellent & 59.79 & 3.9 & 3.95 & 23.38 & 1.66 \\
\hline 491 & Tree of heaven & 7.9 & 4.6 & 10.2 & Fair & 25.76 & 1.93 & 2.54 & 7.2 & 1.21 \\
\hline 492 & Tree of heaven & 15 & 4.8 & 18.4 & Excellent & 41.46 & 3.1 & 2.25 & 33.28 & 2.92 \\
\hline 493 & Tree of heaven & 7.9 & 4.8 & 25.5 & Excellent & 52.91 & 3.96 & 2.07 & 7.22 & 1.22 \\
\hline 494 & Green ash & 9.9 & 8.5 & 8.8 & Excellent & 26.45 & 1.72 & 3 & 13.66 & 1.34 \\
\hline 495 & Boxelder & 14 & 10.5 & 12.9 & Excellent & 86.36 & 7.9 & 6.69 & 37.69 & 3.17 \\
\hline 496 & Tree of heaven & 8.9 & 4.8 & 9.2 & Excellent & 30.08 & 2.25 & 3.29 & 9.62 & 1.43 \\
\hline 497 & Black walnut & 8.9 & 7.8 & 4.7 & Excellent & 41.66 & 3.34 & 8.92 & 10.11 & 1.49 \\
\hline 498 & Black ash & 8.9 & 7.2 & 8.4 & Excellent & 27.85 & 1.66 & 3.33 & 9.41 & 1.35 \\
\hline 499 & Green ash & 13 & 9.6 & 17.8 & Excellent & 108.77 & 7.09 & 6.13 & 23.74 & 1.78 \\
\hline 501 & Northern red oak & 7.1 & 7.1 & 8.5 & Excellent & 48.5 & 3.86 & 5.7 & 6.13 & 1.18 \\
\hline 502 & Eastern white pine & 11.9 & 5.3 & 7.6 & Excellent & 23.01 & 1.48 & 3.03 & 10.42 & 1.1 \\
\hline 503 & Eastern white pine & 8.9 & 4.1 & 5.1 & Excellent & 13.51 & 0.87 & 2.62 & 5.16 & 0.73 \\
\hline 504 & Black walnut & 6.4 & 6.2 & 5.9 & Excellent & 19.05 & 1.53 & 3.22 & 4.48 & 0.93 \\
\hline 505 & Green ash & 7.9 & 6.9 & 4 & Excellent & 7.3 & 0.48 & 1.83 & 7.78 & 0.96 \\
\hline 506 & Boxelder & 18.3 & 8.7 & 30.1 & Excellent & 124.89 & 11.43 & 4.15 & 64.76 & 4.22 \\
\hline 507 & Boxelder & 23.2 & 11.4 & 38.9 & Excellent & 107.57 & 9.84 & 2.76 & 113.75 & 5.82 \\
\hline 508 & Green ash & 14 & 6.9 & 11.4 & Excellent & 27.04 & 1.76 & 2.37 & 20.39 & 1.47 \\
\hline 509 & Black walnut & 7.9 & 7.5 & 18.4 & Excellent & 84.82 & 6.8 & 4.6 & 7.58 & 1.26 \\
\hline 510 & Northern red oak & 7.9 & 6.2 & 9.6 & Excellent & 31.56 & 2.52 & 3.27 & 7.85 & 1.36 \\
\hline 511 & Eastern white pine & 9.9 & 5.2 & 14.1 & Excellent & 56.7 & 3.65 & 4.02 & 7.71 & 0.85 \\
\hline 512 & Red Ash & 13 & 9.1 & 10.7 & Excellent & 54.56 & 4.09 & 5.11 & 26.51 & 2.49 \\
\hline 513 & Red Ash & 13 & 9 & 11.4 & Excellent & 96.54 & 7.23 & 8.47 & 27.73 & 2.49 \\
\hline
\end{tabular}




\begin{tabular}{|c|c|c|c|}
\hline 514 & Black walnut & 19.1 & 8.2 \\
\hline 515 & Littleleaf linden & 9.9 & 5.4 \\
\hline 516 & Bur oak & 8.9 & 5.6 \\
\hline 517 & Bur oak & 6.6 & 5.9 \\
\hline 518 & Black walnut & 8.9 & 6 \\
\hline 519 & Eastern white pine & 9.9 & 5.1 \\
\hline 520 & Green ash & 9.9 & 7.9 \\
\hline 521 & Littleleaf linden & 9.9 & 6.3 \\
\hline 522 & Black walnut & 6.6 & 5.8 \\
\hline 523 & Eastern white pine & 7.9 & 4.7 \\
\hline 524 & Littleleaf linden & 9.9 & 5.5 \\
\hline 525 & Littleleaf linden & 10.9 & 3.6 \\
\hline 526 & Black walnut & 56.9 & 22 \\
\hline 527 & Boxelder & 7.1 & 3.6 \\
\hline 528 & Boxelder & 7.9 & 6.1 \\
\hline 529 & Red Ash & 14 & 6.2 \\
\hline 530 & Green ash & 9.9 & 8.2 \\
\hline 531 & Swamp white oak & 7.1 & 5.5 \\
\hline 532 & Green ash & 9.9 & 9.4 \\
\hline 533 & Green ash & 8.9 & 10.8 \\
\hline 534 & Boxelder & 9.9 & 10.5 \\
\hline 535 & Green ash & 7.9 & 7.2 \\
\hline 536 & Northern catalpa & 7.9 & 6.4 \\
\hline 537 & Northern catalpa & 6.1 & 3.2 \\
\hline 538 & Swamp white oak & 10.9 & 8.3 \\
\hline 539 & Boxelder & 8.9 & 6.8 \\
\hline 540 & Red pine & 24.9 & 10.2 \\
\hline 541 & Black walnut & 71.1 & 19.3 \\
\hline 542 & Red pine & 29 & 12.9 \\
\hline 543 & Green ash & 49 & 19.8 \\
\hline 544 & Austrian pine & 37.1 & 15.2 \\
\hline 545 & Austrian pine & 38.1 & 16 \\
\hline 546 & Austrian pine & 35.1 & 13.4 \\
\hline 547 & Austrian pine & 33 & 12.4 \\
\hline 548 & Austrian pine & 27.9 & 15.2 \\
\hline 549 & Black ash & 61 & 14.6 \\
\hline 550 & Red Ash & 7.1 & 8.6 \\
\hline
\end{tabular}

$\begin{aligned} 26.9 & \text { Excellent } \\ 9.3 & \text { Excellent } \\ 11.4 & \text { Excellent } \\ 5.5 & \text { Excellent } \\ 9.6 & \text { Excellent } \\ 4.7 & \text { Excellent } \\ 10.2 & \text { Excellent } \\ 9.2 & \text { Excellent } \\ 5.8 & \text { Excellent } \\ 6.2 & \text { Excellent } \\ 13.3 & \text { Excellent } \\ 15.1 & \text { Excellent } \\ 165.3 & \text { Excellent } \\ 10.7 & \text { Excellent } \\ 12.5 & \text { Excellent } \\ 12 & \text { Excellent } \\ 16.2 & \text { Excellent } \\ 11.4 & \text { Poor } \\ 11 & \text { Excellent } \\ 13.9 & \text { Excellent } \\ 30.7 & \text { Excellent } \\ 7.7 & \text { Excellent } \\ 12 & \text { Fair } \\ 13.5 & \text { Excellent } \\ 11.4 & \text { Excellent } \\ 18.9 & \text { Excellent } \\ 42 & \text { Fair } \\ 386.7 & \text { Excellent } \\ 36.9 & \text { Fair } \\ 178.8 & \text { Excellent } \\ 53.6 & \text { Dying } \\ 61.4 & \text { Critical } \\ 34.7 & \text { Dying } \\ 33.7 & \text { Dying } \\ 30.7 & \text { Critical } \\ 151.7 & \text { Poor } \\ 13.5 & \text { Excellent }\end{aligned}$

\begin{tabular}{|c|c|c|}
\hline 170.58 & 13.67 & 6.34 \\
\hline 37.84 & 2.83 & 4.06 \\
\hline 35.76 & 3.53 & 3.14 \\
\hline 13.06 & 1.29 & 2.36 \\
\hline 57.98 & 4.65 & 6.01 \\
\hline 15.91 & 1.02 & 3.41 \\
\hline 41.13 & 2.68 & 4.05 \\
\hline 49.3 & 3.69 & 5.39 \\
\hline 46.84 & 3.75 & 8.1 \\
\hline 22.5 & 1.45 & 3.64 \\
\hline 59.46 & 4.45 & 4.47 \\
\hline 57.9 & 4.34 & 3.83 \\
\hline 1487.91 & 119.24 & 9 \\
\hline 35.83 & 3.28 & 3.35 \\
\hline 37.6 & 3.44 & 3 \\
\hline 25.4 & 1.9 & 2.12 \\
\hline 96.09 & 6.27 & 5.93 \\
\hline 22.68 & 2.24 & 1.99 \\
\hline 30.09 & 1.96 & 2.73 \\
\hline 75.64 & 4.93 & 5.44 \\
\hline 162.88 & 14.9 & 5.31 \\
\hline 14.14 & 0.92 & 1.83 \\
\hline 32.35 & 1.97 & 2.71 \\
\hline 19.01 & 1.16 & 1.41 \\
\hline 16.72 & 1.65 & 1.47 \\
\hline 56.8 & 5.2 & 3 \\
\hline 139.25 & 20.48 & 3.31 \\
\hline 2668.29 & 213.84 & 6.9 \\
\hline 96.92 & 14.25 & 2.62 \\
\hline 871.76 & 56.86 & 4.88 \\
\hline 312.69 & 30.14 & 5.84 \\
\hline 498.17 & 48.01 & 8.12 \\
\hline 318.3 & 30.68 & 9.18 \\
\hline 185.64 & 17.89 & 5.5 \\
\hline 138.17 & 13.32 & 4.51 \\
\hline 368.44 & 21.93 & 2.43 \\
\hline 53.33 & 3.99 & 3.95 \\
\hline
\end{tabular}

$\begin{array}{rr}61.24 & 4.19 \\ 8.95 & 1.18 \\ 8.81 & 1.38 \\ 4.2 & 0.9 \\ 9.82 & 1.45 \\ 6.66 & 0.85 \\ 12.83 & 1.26 \\ 8.95 & 1.18 \\ 4.87 & 0.98 \\ 4.16 & 0.62 \\ 8.95 & 1.18 \\ 11.26 & 1.34 \\ 899.07 & 20.36 \\ 7.03 & 1.22 \\ 9.75 & 1.49 \\ 29.43 & 2.69 \\ 13.24 & 1.3 \\ 5.61 & 0.82 \\ 14.92 & 1.45 \\ 13.91 & 1.49 \\ 18.27 & 2.15 \\ 8.07 & 1.12 \\ 7.44 & 1.24 \\ 3.81 & 0.84 \\ 16.77 & 2.08 \\ 12.96 & 1.74 \\ 99.41 & 4.52 \\ 1512.58 & 27.6 \\ 134.53 & 5.48 \\ 407.39 & 8.43 \\ 165.21 & 0.72 \\ 185.08 & 2.14 \\ 140.97 & 0.65 \\ 116.99 & 0.59 \\ 90.75 & 1.47 \\ 784.94 & 12.05 \\ 7.69 & 1.12 \\ & \end{array}$




\begin{tabular}{|c|c|c|c|c|c|c|c|c|c|c|}
\hline 551 & Yellow birch & 14 & 13.2 & 18.4 & Poor & 118.09 & 4.89 & 6.4 & 32.95 & 2.24 \\
\hline 552 & Norway maple & 6.1 & 7 & 7.7 & Excellent & 21.97 & 1.19 & 2.84 & 5.88 & 1.15 \\
\hline 553 & Red Ash & 7.1 & 10.5 & 10.7 & Dying & 29.48 & 2.21 & 2.76 & 7.18 & 0.16 \\
\hline 554 & Red Ash & 7.1 & 10.5 & 5.5 & Dying & 15.24 & 1.14 & 2.76 & 6.75 & 0.16 \\
\hline 555 & Yellow birch & 18 & 12.4 & 26.9 & Dying & 144.17 & 5.97 & 5.36 & 59.28 & 0.61 \\
\hline 556 & Yellow birch & 14 & 9.9 & 16.6 & Dying & 58.05 & 2.4 & 3.49 & 32.95 & 0.44 \\
\hline 557 & Yellow birch & 6.1 & 6.7 & 4 & Critical & 10.54 & 0.44 & 2.64 & 4.89 & 0.42 \\
\hline 558 & Yellow birch & 14 & 9.5 & 15.1 & Fair & 39.92 & 1.65 & 2.64 & 32.95 & 2.97 \\
\hline 559 & Bur oak & 10.9 & 7 & 6.4 & Excellent & 24.2 & 2.39 & 3.75 & 14.72 & 1.86 \\
\hline 560 & Yellow birch & 9.9 & 8.3 & 13.9 & Excellent & 89.48 & 3.71 & 6.44 & 14.94 & 1.92 \\
\hline 561 & Bur oak & 10.9 & 10.8 & 6.9 & Poor & 25.85 & 2.55 & 3.76 & 14.72 & 1.4 \\
\hline 562 & Red Ash & 6.4 & 9.3 & 6.2 & Poor & 17.04 & 1.28 & 2.76 & 5.26 & 0.73 \\
\hline 563 & Black ash & 8.2 & 8.6 & 4.3 & Fair & 11.96 & 0.71 & 2.76 & 7.8 & 1.22 \\
\hline 564 & Black ash & 7.9 & 11.7 & 8 & Fair & 49.51 & 2.95 & 6.16 & 7.12 & 1.16 \\
\hline 565 & Northern catalpa & 40.9 & 17.6 & 88.4 & Dying & 260.48 & 15.86 & 2.95 & 401.79 & 1.88 \\
\hline 566 & Yellow birch & 6.1 & 4.8 & 16 & Fair & 42.16 & 1.75 & 2.64 & 4.89 & 1.04 \\
\hline 567 & Green ash & 7.6 & 10.3 & 13.3 & Fair & 54.93 & 3.58 & 4.13 & 10.32 & 1.29 \\
\hline 568 & Yellow birch & 8.9 & 9.4 & 12.3 & Excellent & 53.9 & 2.23 & 4.37 & 11.65 & 1.67 \\
\hline 569 & Yellow birch & 11.9 & 9.1 & 17.8 & Excellent & 73.34 & 3.04 & 4.13 & 22.95 & 2.43 \\
\hline 570 & Norway maple & 61 & 15.8 & 135.5 & Fair & 962.35 & 51.94 & 7.1 & 981.91 & 19.45 \\
\hline 571 & Northern catalpa & 40.9 & 18.6 & 70.1 & Excellent & 244.02 & 14.86 & 3.48 & 404.04 & 12.71 \\
\hline 572 & Silver maple & 51.1 & 17.4 & 147.1 & Excellent & 288.04 & 15.16 & 1.96 & 623.83 & 12.74 \\
\hline 573 & Siberian elm & 6.1 & 7 & 7 & Excellent & 46.42 & 3.16 & 6.62 & 3.39 & 0.76 \\
\hline 574 & Siberian elm & 6.4 & 7 & 4.7 & Excellent & 22.59 & 1.54 & 4.84 & 3.74 & 0.8 \\
\hline 575 & Siberian elm & 7.9 & 8.6 & 13.5 & Excellent & 64.88 & 4.42 & 4.81 & 6.27 & 1.07 \\
\hline 576 & Silver maple & 79 & 32 & 396.3 & Excellent & 2259.08 & 118.9 & 5.7 & 2188.13 & 28.23 \\
\hline 577 & Black ash & 6.9 & 9.6 & 7 & Excellent & 25.84 & 1.54 & 3.69 & 5.18 & 0.97 \\
\hline 578 & Black ash & 7.9 & 9.4 & 12.9 & Excellent & 61.2 & 3.64 & 4.74 & 7.12 & 1.16 \\
\hline 579 & Green ash & 6.1 & 7.3 & 8 & Excellent & 30.16 & 1.97 & 3.75 & 5.32 & 0.84 \\
\hline 580 & Green ash & 6.1 & 7.5 & 6.2 & Critical & 21.91 & 1.43 & 3.55 & 5.43 & 0.35 \\
\hline 581 & Siberian elm & 11.9 & 9.1 & 16.6 & Excellent & 71.79 & 4.89 & 4.31 & 17.02 & 1.88 \\
\hline 582 & Green ash & 10.4 & 7.4 & 9.8 & Excellent & 22.53 & 1.47 & 2.29 & 13.23 & 1.25 \\
\hline 583 & Green ash & 13 & 10.7 & 16.2 & Excellent & 70.96 & 4.63 & 4.38 & 26 & 1.94 \\
\hline 584 & Green ash & 9.9 & 8.3 & 14.9 & Poor & 59.05 & 3.85 & 3.96 & 13.33 & 0.99 \\
\hline 585 & Red Ash & 7.9 & 5.1 & 15.6 & Excellent & 58.17 & 4.36 & 3.74 & 9 & 1.22 \\
\hline 586 & Black walnut & 22.1 & 9 & 35.3 & Excellent & 317.37 & 25.43 & 8.99 & 87.79 & 5.17 \\
\hline 587 & Black walnut & 22.8 & 10.2 & 33.1 & Excellent & 377.52 & 30.26 & 11.4 & 95.7 & 5.44 \\
\hline
\end{tabular}




\begin{tabular}{|c|c|c|c|c|c|}
\hline 588 & Norway maple & 6.1 & 6 & 7 & Excellent \\
\hline 589 & Norway maple & 6.9 & 6.8 & 9.6 & Excellent \\
\hline 590 & Norway maple & 8.4 & 6.4 & 4.1 & Excellent \\
\hline 591 & Black walnut & 18 & 10 & 15.6 & Excellent \\
\hline 592 & Norway maple & 7.1 & 5.8 & 7.6 & Excellent \\
\hline 593 & Norway maple & 8.9 & 5 & 10.2 & Excellent \\
\hline 594 & Black walnut & 6.1 & 6.6 & 3.5 & Excellent \\
\hline 595 & Black walnut & 10.9 & 7.8 & 8.5 & Excellent \\
\hline 596 & Black walnut & 8.9 & 6 & 9.6 & Excellent \\
\hline 597 & serviceberry spp & 10.4 & 5.8 & 10.2 & Poor \\
\hline 598 & Norway maple & 7.9 & 7.4 & 10.5 & Fair \\
\hline 599 & Norway maple & 10.4 & 7.2 & 10.7 & Fair \\
\hline 600 & Norway maple & 7.6 & 5.4 & 4 & Fair \\
\hline 601 & Norway maple & 7.9 & 7 & 6.6 & Fair \\
\hline 602 & Norway maple & 10.9 & 8.4 & 11.4 & Fair \\
\hline 603 & Norway maple & 8.9 & 7 & 7.3 & Fair \\
\hline 604 & Norway maple & 8.4 & 8.4 & 6.2 & Fair \\
\hline 605 & Norway maple & 6.9 & 8.6 & 3.5 & Fair \\
\hline 606 & Norway maple & 6.4 & 7.4 & 3.2 & Fair \\
\hline 607 & Norway maple & 6.4 & 5.2 & 12.5 & Excellent \\
\hline 608 & Norway maple & 7.9 & 5.6 & 5.1 & Excellent \\
\hline 609 & Wych elm & 14 & 7.8 & 5.1 & Excellent \\
\hline 610 & Norway maple & 9.9 & 7 & 13.3 & Good \\
\hline 611 & Norway maple & 9.9 & 8.8 & 6.9 & Excellent \\
\hline 612 & Norway maple & 10.9 & 7.8 & 3.7 & Fair \\
\hline 613 & Black walnut & 14 & 7 & 20.8 & Excellent \\
\hline 614 & Norway maple & 16.6 & 6.8 & 16 & Excellent \\
\hline 615 & Norway maple & 7.1 & 5.4 & 5.9 & Good \\
\hline
\end{tabular}

$\begin{array}{rrr}31.54 & 1.7 & 4.5 \\ 46.37 & 2.5 & 4.81 \\ 19.83 & 1.07 & 4.83 \\ 219.17 & 17.56 & 14.09 \\ 33.74 & 1.82 & 4.44 \\ 40.5 & 2.19 & 3.99 \\ 31.77 & 2.55 & 9.15 \\ 97.5 & 7.81 & 11.46 \\ 50.03 & 4.01 & 5.18 \\ 26.55 & 2.01 & 2.61 \\ 54.43 & 2.94 & 5.18 \\ 52.22 & 2.82 & 4.89 \\ 20.3 & 1.1 & 5.08 \\ 27.79 & 1.5 & 4.22 \\ 57.22 & 3.09 & 5.02 \\ 31.03 & 1.68 & 4.25 \\ 27.19 & 1.47 & 4.4 \\ 15.62 & 0.84 & 4.5 \\ 14.23 & 0.77 & 4.48 \\ 33.91 & 1.83 & 2.71 \\ 16.79 & 0.91 & 3.26 \\ 26.59 & 1.81 & 5.16 \\ 50.89 & 2.75 & 3.83 \\ 34.22 & 1.85 & 4.98 \\ 15.58 & 0.84 & 4.24 \\ 99.72 & 7.99 & 4.79 \\ 78.79 & 4.25 & 4.93 \\ 20.65 & 1.11 & 3.49\end{array}$

$\begin{array}{rr}5.64 & 1.11 \\ 7.47 & 1.3 \\ 11.27 & 1.61 \\ 54.76 & 3.93 \\ 7.75 & 1.31 \\ 12.12 & 1.66 \\ 4.11 & 0.89 \\ 16.38 & 1.96 \\ 9.82 & 1.45 \\ 14.22 & 1.35 \\ 10.23 & 1.54 \\ 18.4 & 2.11 \\ 8.84 & 1.4 \\ 10.09 & 1.53 \\ 21.15 & 2.29 \\ 13.05 & 1.75 \\ 12.08 & 1.7 \\ 7.99 & 1.37 \\ 6.51 & 1.22 \\ 5.94 & 1.13 \\ 9.56 & 1.47 \\ 24.81 & 2.33 \\ 16.44 & 1.98 \\ 17.4 & 2.07 \\ 20.77 & 2.26 \\ 28.97 & 2.71 \\ 49.67 & 3.62 \\ 7.62 & 1.3\end{array}$




\section{Appendix C: Species Characteristics (Eco)}

\begin{tabular}{|c|c|c|c|c|c|c|c|c|c|c|c|c|}
\hline Species Name & $\begin{array}{l}\text { Tree } \\
\text { Count }\end{array}$ & $\%$ & $\begin{array}{l}\text { Canopy Cover } \\
\text { (m2) }\end{array}$ & $\%$ & $\begin{array}{l}\text { Leaf Area } \\
\text { (m2) }\end{array}$ & $\%$ & Leaf Biomass (kg) & $\%$ & $\begin{array}{l}\text { Carbon Storage } \\
(\mathrm{kg})\end{array}$ & $\%$ & $\begin{array}{l}\text { Gross Carbon Seq } \\
(\mathrm{kg} / \mathrm{yr})\end{array}$ & $\%$ \\
\hline $\begin{array}{l}\text { American } \\
\text { basswood } \\
\text { American }\end{array}$ & 7 & 1.16 & 397.7 & 0.95 & 2619.3 & 1.4 & 76.5 & 0.61 & 1977.6 & 1.1 & 52.4 & 1.23 \\
\hline sycamore & 1 & 0.17 & 153.7 & 0.37 & 1152.9 & 0.62 & 55.9 & 0.44 & 424 & 0.24 & 13.1 & 0.31 \\
\hline apple spp & 1 & 0.17 & 7.7 & 0.02 & 34.8 & 0.02 & 3 & 0.02 & 15.7 & 0.01 & 1.9 & 0.04 \\
\hline Austrian pine & 6 & 1 & 237.7 & 0.57 & 1608.2 & 0.86 & 155 & 1.23 & 725 & 0.4 & 7 & 0.17 \\
\hline Black ash & 11 & 1.83 & 589.2 & 1.41 & 2444.7 & 1.31 & 145.5 & 1.16 & 2128.8 & 1.18 & 54 & 1.27 \\
\hline Black walnut & 27 & 4.49 & 1026 & 2.45 & 8492.9 & 4.54 & 680.7 & 5.41 & 3068.9 & 1.71 & 101.5 & 2.39 \\
\hline Blue spruce & 2 & 0.33 & 20.5 & 0.05 & 159.3 & 0.09 & 27 & 0.21 & 46.7 & 0.03 & 3.7 & 0.09 \\
\hline Boxelder & 21 & 3.49 & 509.3 & 1.22 & 1919.9 & 1.03 & 175.6 & 1.4 & 772.9 & 0.43 & 50.8 & 1.19 \\
\hline Bur oak & 18 & 3 & 1646.1 & 3.93 & 5611.6 & 3 & 553.8 & 4.4 & 9058.3 & 5.04 & 188.6 & 4.44 \\
\hline Douglas fir & 3 & 0.5 & 38.7 & 0.09 & 320.4 & 0.17 & 50.2 & 0.4 & 33.9 & 0.02 & 1.4 & 0.03 \\
\hline Eastern white pine & 38 & 6.32 & 559.3 & 1.33 & 2847.3 & 1.52 & 183.1 & 1.45 & 1624.9 & 0.9 & 75.6 & 1.78 \\
\hline Freeman maple & 23 & 3.83 & 349.7 & 0.83 & 2564.4 & 1.37 & 144.3 & 1.15 & 706 & 0.39 & 59.8 & 1.41 \\
\hline Green ash & 41 & 6.82 & 2402.1 & 5.73 & 8325.3 & 4.45 & 543 & 4.31 & 4307.4 & 2.39 & 111.4 & 2.62 \\
\hline Honeylocust & 41 & 6.82 & 4581.3 & 10.93 & 6865.2 & 3.67 & 718.9 & 5.71 & 13403.7 & 7.45 & 385.1 & 9.06 \\
\hline $\begin{array}{l}\text { Horsechestnut } \\
\text { Kentucky }\end{array}$ & 2 & 0.33 & 332.2 & 0.79 & 1787.3 & 0.95 & 125 & 0.99 & 2415.7 & 1.34 & 48.3 & 1.14 \\
\hline coffeetree & 7 & 1.16 & 466 & 1.11 & 2005.6 & 1.07 & 150.2 & 1.19 & 1661.4 & 0.92 & 38.1 & 0.9 \\
\hline Littleleaf linden & 41 & 6.82 & 3760.6 & 8.97 & 22143.5 & 11.83 & 1658.7 & 13.18 & 17761.1 & 9.87 & 392.5 & 9.24 \\
\hline London plane & 6 & 1 & 1054.4 & 2.52 & 6858.2 & 3.66 & 315 & 2.5 & 4584.5 & 2.55 & 102.5 & 2.41 \\
\hline Northern catalpa & 8 & 1.33 & 608.9 & 1.45 & 1814.3 & 0.97 & 110.5 & 0.88 & 3695.1 & 2.05 & 85.2 & 2 \\
\hline Northern red oak & 27 & 4.49 & 814.3 & 1.94 & 3333.7 & 1.78 & 265.6 & 2.11 & 3411.8 & 1.9 & 106.9 & 2.52 \\
\hline Norway maple & 128 & 21.3 & 13279.3 & 31.69 & 69689.5 & 37.23 & 3761.4 & 29.88 & 62928.4 & 34.98 & 1469.9 & 34.59 \\
\hline Paper birch & 1 & 0.17 & 6.6 & 0.02 & 27.3 & 0.01 & 1.9 & 0.02 & 5.6 & 0 & 1.2 & 0.03 \\
\hline Red Ash & 37 & 6.16 & 619.9 & 1.48 & 2536.3 & 1.35 & 189.9 & 1.51 & 1093.2 & 0.61 & 65.7 & 1.55 \\
\hline Red maple & 4 & 0.67 & 131.3 & 0.31 & 650.1 & 0.35 & 43.8 & 0.35 & 547.7 & 0.3 & 21.1 & 0.5 \\
\hline Red pine & 26 & 4.33 & 1346.8 & 3.21 & 5483 & 2.93 & 806.3 & 6.41 & 5534.4 & 3.08 & 136.7 & 3.22 \\
\hline serviceberry spp & 5 & 0.83 & 56.5 & 0.13 & 214.5 & 0.11 & 16.3 & 0.13 & 111.8 & 0.06 & 9.9 & 0.23 \\
\hline
\end{tabular}




\begin{tabular}{|c|c|c|c|c|c|c|c|c|c|c|c|c|}
\hline Siberian elm & 9 & 1.5 & 152.5 & 0.36 & 850.6 & 0.45 & 57.9 & 0.46 & 160.3 & 0.09 & 15.2 & 0.36 \\
\hline Silver maple & 21 & 3.49 & 2743.6 & 6.55 & 11434.7 & 6.11 & 601.8 & 4.78 & 11784.2 & 6.55 & 197.9 & 4.66 \\
\hline Sugar maple & 13 & 2.16 & 1361.3 & 3.25 & 5357.4 & 2.86 & 322.7 & 2.56 & 6485.2 & 3.6 & 158.8 & 3.74 \\
\hline Swamp white oak & 4 & 0.67 & 1044.3 & 2.49 & 3271.4 & 1.75 & 322.9 & 2.56 & 9436.7 & 5.25 & 102.8 & 2.42 \\
\hline Tree of heaven & 5 & 0.83 & 96.4 & 0.23 & 336.2 & 0.18 & 25.2 & 0.2 & 81.4 & 0.05 & 9.2 & 0.22 \\
\hline Tulip tree & 1 & 0.17 & 9.6 & 0.02 & 47.8 & 0.03 & 2.8 & 0.02 & 4.1 & 0 & 0.8 & 0.02 \\
\hline White oak & 4 & 0.67 & 1310.8 & 3.13 & 3430.6 & 1.83 & 249.6 & 1.98 & 9565.5 & 5.32 & 158.3 & 3.73 \\
\hline Wych elm & 3 & 0.5 & 46.5 & 0.11 & 315.3 & 0.17 & 21.5 & 0.17 & 122.9 & 0.07 & 8.5 & 0.2 \\
\hline Yellow birch & 9 & 1.5 & 141 & 0.34 & 629.7 & 0.34 & 26.1 & 0.21 & 217.5 & 0.12 & 13.7 & 0.32 \\
\hline TOTAL & 601 & 100 & 41902 & 100 & 187183 & 100 & 12587 & 100 & 179902 & 100 & 4249 & 100 \\
\hline
\end{tabular}


Appendix D: Leaf Area Comparison (Eco v. Streets)

\begin{tabular}{|c|c|c|c|c|c|c|}
\hline Tree ID & Species Name & Leaf Area $\left(m^{2}\right)$ Eco & Leaf Area $\left(\mathrm{m}^{2}\right)$ Streets & CLE & Tree Condition (Eco) & $\mathrm{DBH}(\mathrm{cm})$ \\
\hline 322 & Black walnut & 626.49 & 52 & 5 & Dying & 14 \\
\hline 8 & Littleleaf linden & 580.25 & 268 & 5 & Excellent & 49 \\
\hline 13 & Littleleaf linden & 205.74 & 171 & 5 & Excellent & 31 \\
\hline 16 & Littleleaf linden & 496.19 & 268 & 5 & Excellent & 46 \\
\hline 17 & Littleleaf linden & 248.3 & 268 & 5 & Excellent & 48.5 \\
\hline 19 & Littleleaf linden & 312.26 & 268 & 5 & Excellent & 48.5 \\
\hline 20 & Green ash & 446.97 & 252 & 5 & Excellent & 45.5 \\
\hline 22 & Silver maple & 112.42 & 67 & 5 & Excellent & 13.2 \\
\hline 23 & Silver maple & 298.93 & 268 & 5 & Excellent & 30.5 \\
\hline 24 & Northern red oak & 261.45 & 133 & 5 & Excellent & 28.2 \\
\hline 32 & Honeylocust & 148.91 & 294 & 5 & Excellent & 32.8 \\
\hline 48 & Norway maple & 1152.72 & 430 & 5 & Excellent & 65 \\
\hline 53 & Norway maple & 746.68 & 273 & 5 & Excellent & 50 \\
\hline 62 & Norway maple & 626.41 & 151 & 5 & Excellent & 41.9 \\
\hline 63 & Norway maple & 188.67 & 151 & 5 & Excellent & 30.5 \\
\hline 70 & serviceberry spp & 90.77 & 43 & 5 & Excellent & 20.6 \\
\hline 72 & Honeylocust & 23.68 & 56 & 5 & Excellent & 10.4 \\
\hline 73 & Honeylocust & 19.55 & 56 & 5 & Excellent & 9.4 \\
\hline 74 & Honeylocust & 16.79 & 56 & 5 & Excellent & 8.9 \\
\hline 75 & Honeylocust & 154.2 & 294 & 5 & Excellent & 32.8 \\
\hline 76 & Honeylocust & 20.01 & 294 & 5 & Excellent & 7.1 \\
\hline 78 & Red maple & 31.4 & 74 & 5 & Excellent & 7.9 \\
\hline 79 & Northern red oak & 12.87 & 9 & 5 & Excellent & 6.9 \\
\hline 82 & Northern red oak & 28.62 & 9 & 5 & Excellent & 7.4 \\
\hline 83 & Littleleaf linden & 575.05 & 268 & 5 & Excellent & 75.2 \\
\hline 84 & Honeylocust & 181.09 & 294 & 5 & Excellent & 38.1 \\
\hline 85 & Littleleaf linden & 685.98 & 268 & 5 & Excellent & 55.6 \\
\hline 86 & Honeylocust & 484.23 & 497 & 5 & Excellent & 56.9 \\
\hline 87 & Littleleaf linden & 640.94 & 268 & 5 & Excellent & 57.9 \\
\hline 88 & Honeylocust & 231.45 & 294 & 5 & Excellent & 45.5 \\
\hline 89 & Norway maple & 521.8 & 100 & 5 & Excellent & 37.1 \\
\hline 90 & Honeylocust & 169.19 & 294 & 5 & Excellent & 34.3 \\
\hline 91 & Honeylocust & 166.25 & 294 & 5 & Excellent & 31.5 \\
\hline 93 & Norway maple & 546.34 & 273 & 5 & Excellent & 56.9 \\
\hline
\end{tabular}




$\begin{array}{ll}104 & \text { Honeylocust } \\ 105 & \text { Littleleaf linden } \\ 106 & \text { Norway maple } \\ 108 & \text { Littleleaf linden } \\ 112 & \text { Green ash } \\ 116 & \text { Honeylocust } \\ 117 & \text { Norway maple } \\ 130 & \text { apple spp } \\ 131 & \text { Norway maple } \\ 132 & \text { Honeylocust } \\ 133 & \text { Norway maple } \\ 135 & \text { Honeylocust } \\ 137 & \text { Littleleaf linden } \\ 138 & \text { Honeylocust } \\ 139 & \text { Honeylocust } \\ 140 & \text { Norway maple } \\ 141 & \text { Honeylocust } \\ 142 & \text { Bur oak } \\ 144 & \text { Norway maple } \\ 146 & \text { Northern red oak } \\ 147 & \text { London plane } \\ 149 & \text { Norway maple } \\ 165 & \text { Norway maple } \\ 168 & \text { Littleleaf linden } \\ 169 & \text { Silver maple } \\ 170 & \text { Tulip tree } \\ 173 & \text { American sycamore } \\ 179 & \text { Norway maple } \\ 180 & \text { Norway maple } \\ 181 & \text { American basswood } \\ 184 & \text { Norway maple } \\ 185 & \text { Norway maple } \\ 190 & \text { Honeylocust } \\ 191 & \text { Honeylocust } \\ 192 & \text { Honeylocust } \\ 193 & \text { Norway maple } \\ 194 & \text { Swamp white oak } \\ & \end{array}$

174.85
611.78
1287.12
1916.81
389.38
386.22
475.2
34.84
580.47
341.89
207.72
167.09
386.32
6.43
10.4
395.69
167.72
1189.45
422.59
1033.74
1201.05
958.88
1398.93
1130.4
1524.23
47.78
1152.94
536.58
571.36
42.61
504.28
551.8
27.61
51.08
15.48
1058.07
1367.62

294
268
430
268
252
497
151
19
273
497
64
294
294
2
2
64
294
772
273
557
223
151
273
268
574
14
223
273
273
31
273
273
56

509

\begin{tabular}{|c|c|c|}
\hline 5 & Excellent & 31 \\
\hline 5 & Excellent & 55.1 \\
\hline 5 & Excellent & 70.1 \\
\hline 5 & Excellent & 83.1 \\
\hline 5 & Excellent & 42.9 \\
\hline 5 & Excellent & 53.1 \\
\hline 5 & Excellent & 40.9 \\
\hline 5 & Excellent & 10.9 \\
\hline 5 & Excellent & 52.1 \\
\hline 5 & Excellent & 47 \\
\hline 5 & Excellent & 30 \\
\hline 5 & Excellent & 42.9 \\
\hline 5 & Excellent & 31 \\
\hline 5 & Excellent & 7.1 \\
\hline 5 & Excellent & 6.1 \\
\hline 5 & Excellent & 30 \\
\hline 5 & Excellent & 38.1 \\
\hline 5 & Excellent & 77 \\
\hline 5 & Excellent & 50 \\
\hline 5 & Excellent & 69.1 \\
\hline 5 & Excellent & 36.1 \\
\hline 5 & Excellent & 43.9 \\
\hline 5 & Excellent & 57.9 \\
\hline 5 & Excellent & 69.1 \\
\hline 5 & Excellent & 64 \\
\hline 5 & Excellent & 6.6 \\
\hline 5 & Excellent & 41.9 \\
\hline 5 & Excellent & 54.1 \\
\hline 5 & Excellent & 50 \\
\hline 5 & Excellent & 7.9 \\
\hline 5 & Excellent & 53.1 \\
\hline 5 & Excellent & 50 \\
\hline 5 & Excellent & 7.9 \\
\hline 5 & Excellent & 8.6 \\
\hline 5 & Excellent & 7.9 \\
\hline 5 & Excellent & 57.9 \\
\hline 5 & Excellent & 103.1 \\
\hline
\end{tabular}




$\begin{array}{ll}195 & \text { Norway maple } \\ 197 & \text { Littleleaf linden } \\ 198 & \text { Norway maple } \\ 199 & \text { Norway maple } \\ 201 & \text { Honeylocust } \\ 204 & \text { American basswood } \\ 206 & \text { American basswood } \\ 207 & \text { Norway maple } \\ 214 & \text { Sugar maple } \\ 215 & \text { Sugar maple } \\ 216 & \text { Sugar maple } \\ 220 & \text { Honeylocust } \\ 223 & \text { American basswood } \\ 232 & \text { Norway maple } \\ 233 & \text { Norway maple } \\ 234 & \text { Norway maple } \\ 235 & \text { Norway maple } \\ 238 & \text { Honeylocust } \\ 239 & \text { Honeylocust } \\ 240 & \text { Honeylocust } \\ 241 & \text { Honeylocust } \\ 242 & \text { Honeylocust } \\ 243 & \text { Honeylocust } \\ 244 & \text { Norway maple } \\ 245 & \text { Sugar maple } \\ 251 & \text { Austrian pine } \\ 252 & \text { Honeylocust } \\ 253 & \text { Norway maple } \\ 267 & \text { Norway maple } \\ 268 & \text { Norway maple } \\ 270 & \text { Norway maple } \\ 273 & \text { Norway maple } \\ 276 & \text { Littleleaf linden } \\ 277 & \text { Norway maple } \\ 289 & \text { Green ash } \\ 290 & \text { Bur oak } \\ 294 & \text { London plane } \\ & \end{array}$

1045.33
549.98
529.22
386.52
444.4
668.73
448.7
583.14
490.47
368.44
514.33
151.5
767.42
251.43
1058.07
625.99
608.1
21.98
22.37
14.45
30.06
21.67
21.52
462.91
671.17
155.19
405.76
512.5
870.86
1394.35
1130.4
1452.19
1045.33
1452.19
820.74
68.56
666.53

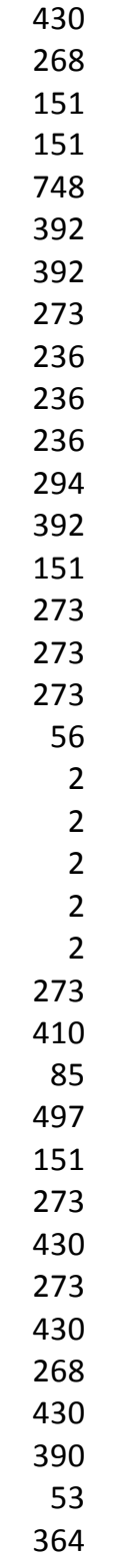

\begin{tabular}{|c|c|c|}
\hline 5 & Excellent & 61 \\
\hline 5 & Excellent & 78 \\
\hline 5 & Excellent & 39.1 \\
\hline 5 & Excellent & 34 \\
\hline 5 & Excellent & 61 \\
\hline 5 & Excellent & 56.9 \\
\hline 5 & Excellent & 48 \\
\hline 5 & Excellent & 51.1 \\
\hline 5 & Excellent & 37.1 \\
\hline 5 & Excellent & 41.9 \\
\hline 5 & Excellent & 35.1 \\
\hline 5 & Excellent & 35.1 \\
\hline 5 & Excellent & 53.1 \\
\hline 5 & Excellent & 45 \\
\hline 5 & Excellent & 58.9 \\
\hline 5 & Excellent & 55.1 \\
\hline 5 & Excellent & 48 \\
\hline 5 & Excellent & 7.9 \\
\hline 5 & Excellent & 7.1 \\
\hline 5 & Excellent & 7.1 \\
\hline 5 & Excellent & 7.1 \\
\hline 5 & Excellent & 7.1 \\
\hline 5 & Excellent & 7.1 \\
\hline 5 & Excellent & 52.1 \\
\hline 5 & Excellent & 53.1 \\
\hline 5 & Excellent & 16 \\
\hline 5 & Excellent & 48 \\
\hline 5 & Excellent & 41.9 \\
\hline 5 & Excellent & 48 \\
\hline 5 & Excellent & 72.9 \\
\hline 5 & Excellent & 59.9 \\
\hline 5 & Excellent & 64 \\
\hline 5 & Excellent & 53.1 \\
\hline 5 & Excellent & 67.1 \\
\hline 5 & Excellent & 59.9 \\
\hline 5 & Excellent & 15 \\
\hline 5 & Excellent & 50 \\
\hline
\end{tabular}




$\begin{array}{llr}357 & \text { Swamp white oak } & 1864.37 \\ 365 & \text { Freeman maple } & 126.11 \\ 366 & \text { Northern red oak } & 78.12 \\ 367 & \text { Freeman maple } & 81.81 \\ 368 & \text { Freeman maple } & 87.43 \\ 369 & \text { Eastern white pine } & 29.26 \\ 370 & \text { Eastern white pine } & 28.79 \\ 371 & \text { Eastern white pine } & 40.94 \\ 372 & \text { Northern red oak } & 39.82 \\ 373 & \text { Northern red oak } & 53.47 \\ 374 & \text { Kentucky coffeetree } & 89.56 \\ 376 & \text { Freeman maple } & 154.02 \\ 377 & \text { Freeman maple } & 368.58 \\ 396 & \text { Bur oak } & 26.16 \\ 401 & \text { Kentucky coffeetree } & 82.2 \\ 402 & \text { Freeman maple } & 137.39 \\ 406 & \text { Bur oak } & 32.83 \\ 411 & \text { Freeman maple } & 81.28 \\ 414 & \text { Freeman maple } & 25.58 \\ 424 & \text { Wych elm } & 229.55 \\ 427 & \text { Bur oak } & 22.62 \\ 431 & \text { Kentucky coffeetree } & 48.01 \\ 432 & \text { Freeman maple } & 47.76 \\ 439 & \text { Green ash } & 23.01 \\ 441 & \text { Kentucky coffeetree } & 46.84 \\ 444 & \text { Freeman maple } & 96.09 \\ 445 & \text { Freeman maple } & \end{array}$

\begin{tabular}{|c|c|c|c|}
\hline 1,009 & 5 & Excellent & 105.9 \\
\hline 67 & 5 & Excellent & 9.9 \\
\hline 60 & 5 & Excellent & 9.9 \\
\hline 67 & 5 & Excellent & 10.9 \\
\hline 67 & 5 & Excellent & 13 \\
\hline 3 & 5 & Excellent & 7.1 \\
\hline 39 & 5 & Excellent & 8.9 \\
\hline 39 & 5 & Excellent & 9.9 \\
\hline 60 & 5 & Excellent & 9.9 \\
\hline 60 & 5 & Excellent & 10.9 \\
\hline 52 & 5 & Excellent & 8.9 \\
\hline 67 & 5 & Excellent & 13 \\
\hline 146 & 5 & Excellent & 20.1 \\
\hline 53 & 5 & Excellent & 7.9 \\
\hline 52 & 5 & Excellent & 10.9 \\
\hline 67 & 5 & Excellent & 13 \\
\hline 53 & 5 & Excellent & 9.9 \\
\hline 67 & 5 & Excellent & 8.9 \\
\hline 4 & 5 & Excellent & 7.1 \\
\hline 159 & 5 & Excellent & 23.9 \\
\hline 53 & 5 & Excellent & 8.9 \\
\hline 52 & 5 & Excellent & 8.9 \\
\hline 74 & 5 & Excellent & 7.9 \\
\hline 62 & 5 & Excellent & 10.6 \\
\hline 52 & 5 & Excellent & 9.9 \\
\hline 74 & 5 & Excellent & 13 \\
\hline 74 & 5 & Excellent & 11.4 \\
\hline 62 & 5 & Excellent & 8.9 \\
\hline 19 & 5 & Excellent & 7.9 \\
\hline 62 & 5 & Excellent & 8.9 \\
\hline 3 & 5 & Excellent & 7.1 \\
\hline 62 & 5 & Excellent & 7.9 \\
\hline 52 & 5 & Excellent & 8.9 \\
\hline 9 & 5 & Excellent & 7.1 \\
\hline 39 & 5 & Excellent & 11.9 \\
\hline 14 & 5 & Excellent & 6.6 \\
\hline 62 & 5 & Excellent & 9.9 \\
\hline
\end{tabular}




\begin{tabular}{|c|c|}
\hline 543 & Green ash \\
\hline 576 & Silver maple \\
\hline 586 & Black walnut \\
\hline 587 & Black walnut \\
\hline 182 & Northern catalpa \\
\hline 183 & Silver maple \\
\hline 202 & Red pine \\
\hline 203 & Red pine \\
\hline 236 & Northern catalpa \\
\hline 422 & Northern red oak \\
\hline 428 & Northern red oak \\
\hline 429 & Freeman maple \\
\hline 430 & Northern red oak \\
\hline 451 & Wych elm \\
\hline 570 & Norway maple \\
\hline 1 & Silver maple \\
\hline 7 & Norway maple \\
\hline 12 & Norway maple \\
\hline 21 & Littleleaf linden \\
\hline 205 & American basswood \\
\hline 423 & Kentucky coffeetree \\
\hline 2 & Norway maple \\
\hline 31 & Norway maple \\
\hline 71 & Norway maple \\
\hline 114 & Norway maple \\
\hline 226 & Sugar maple \\
\hline 327 & Green ash \\
\hline 3 & Norway maple \\
\hline 287 & Norway maple \\
\hline 545 & Austrian pine \\
\hline 546 & Austrian pine \\
\hline 4 & Littleleaf linden \\
\hline 6 & Littleleaf linden \\
\hline 9 & Littleleaf linden \\
\hline 10 & Norway maple \\
\hline 14 & Norway maple \\
\hline 15 & Norway maple \\
\hline
\end{tabular}

871.76
2259.08
317.37
377.52
169.05
489.14
160.74
192.85
340
60.99
32.68
27.28
49.36
59.11
962.35
23.87
424.06
456.36
320.44
186.56
36.49
446.3
373.61
462.46
427.11
261.86
459.95
559.1
582.62
498.17
318.3
527.35
537.57
604.59
573.91
288.19
232.62

390
757
134
134
376
411
85
85
376
60
60
74
60
71
430
4
151
151
268
215
52
151
64
151
273
107
252
151
273
159
159
268
268
268
273

$\begin{array}{llr}5 & \text { Excellent } & 49 \\ 5 & \text { Excellent } & 79 \\ 5 & \text { Excellent } & 22.1 \\ 5 & \text { Excellent } & 22.8 \\ 5 & \text { Fair } & 46 \\ 5 & \text { Fair } & 59.9 \\ 5 & \text { Fair } & 24.9 \\ 5 & \text { Fair } & 26.9 \\ 5 & \text { Fair } & 51.1 \\ 5 & \text { Fair } & 9.9 \\ 5 & \text { Fair } & 8.9 \\ 5 & \text { Fair } & 8.9 \\ 5 & \text { Fair } & 8.9 \\ 5 & \text { Fair } & 8.9 \\ 5 & \text { Fair } & 61 \\ 5 & \text { Good } & 7.1 \\ 5 & \text { Good } & 34.3 \\ 5 & \text { Good } & 33.8 \\ 5 & \text { Good } & 77.3 \\ 5 & \text { Good } & 41.9 \\ 5 & \text { Good } & 8.9 \\ 5 & \text { Poor } & 31.8 \\ 5 & \text { Poor } & 28.4 \\ 5 & \text { Poor } & 31 \\ 5 & \text { Poor } & 50 \\ 5 & \text { Poor } & 26.9 \\ 5 & \text { Poor } & 34.8 \\ 4 & \text { Critical } & \end{array}$




$\begin{aligned} 47 & \text { Norway maple } \\ 49 & \text { Silver maple } \\ 50 & \text { London plane } \\ 52 & \text { Silver maple } \\ 56 & \text { Eastern white pine } \\ 64 & \text { Norway maple } \\ 65 & \text { Blue spruce } \\ 66 & \text { Blue spruce } \\ 67 & \text { Douglas fir } \\ 68 & \text { Douglas fir } \\ 69 & \text { Douglas fir } \\ 77 & \text { Red maple } \\ 80 & \text { Bur oak } \\ 81 & \text { Bur oak } \\ 92 & \text { Red maple } \\ 94 & \text { Silver maple } \\ 95 & \text { Honeylocust } \\ 96 & \text { Honeylocust } \\ 97 & \text { Littleleaf linden } \\ 98 & \text { Littleleaf linden } \\ 100 & \text { Green ash } \\ 101 & \text { Norway maple } \\ 102 & \text { Honeylocust } \\ 107 & \text { Littleleaf linden } \\ 109 & \text { Norway maple } \\ 111 & \text { Littleleaf linden } \\ 113 & \text { Norway maple } \\ 115 & \text { Littleleaf linden } \\ 118 & \text { Norway maple } \\ 119 & \text { Littleleaf linden } \\ 120 & \text { Littleleaf linden } \\ 121 & \text { Norway maple } \\ 129 & \text { Norway maple } \\ 148 & \text { Black ash } \\ 150 & \text { Northern red oak } \\ 152 & \text { Norway maple } \\ 157 & \text { Littleleaf linden } \\ & \end{aligned}$

1518.46
1016.26
1601.68
1454.13
48.85
563.41
52.47
106.79
106.79
106.79
106.79
28.97
165.59
97.76
446.07
981.8
281.05
141.27
567.65
593.8
465.34
568.16
370.56
703.67
612.85
161.41
450.16
625.3
387.39
339.67
555.53
395.69
1720.59
880.18
982.37
1201.05
1452.19

430
757
535
574
39
151
39
39
39
39
39
74
241
122
260
411
748
294
268
268
252
151
497
268
273
90
273
171
151
171
171
151
430
390
557
273
268

\begin{tabular}{|c|c|c|}
\hline 4 & Excellent & 67.1 \\
\hline 4 & Excellent & 79.2 \\
\hline 4 & Excellent & 64.3 \\
\hline 4 & Excellent & 67.6 \\
\hline 4 & Excellent & 10.9 \\
\hline 4 & Excellent & 41.9 \\
\hline 4 & Excellent & 11.9 \\
\hline 4 & Excellent & 11.9 \\
\hline 4 & Excellent & 11.9 \\
\hline 4 & Excellent & 11.9 \\
\hline 4 & Excellent & 11.9 \\
\hline 4 & Excellent & 7.9 \\
\hline 4 & Excellent & 37.8 \\
\hline 4 & Excellent & 23.1 \\
\hline 4 & Excellent & 42.9 \\
\hline 4 & Excellent & 59.9 \\
\hline 4 & Excellent & 63 \\
\hline 4 & Excellent & 40.9 \\
\hline 4 & Excellent & 56.9 \\
\hline 4 & Excellent & 54.1 \\
\hline 4 & Excellent & 34 \\
\hline 4 & Excellent & 43.9 \\
\hline 4 & Excellent & 50 \\
\hline 4 & Excellent & 51.1 \\
\hline 4 & Excellent & 47 \\
\hline 4 & Excellent & 27.9 \\
\hline 4 & Excellent & 55.9 \\
\hline 4 & Excellent & 37.1 \\
\hline 4 & Excellent & 34 \\
\hline 4 & Excellent & 41.9 \\
\hline 4 & Excellent & 37.1 \\
\hline 4 & Excellent & 41.9 \\
\hline 4 & Excellent & 75.9 \\
\hline 4 & Excellent & 53.1 \\
\hline 4 & Excellent & 66 \\
\hline 4 & Excellent & 48 \\
\hline 4 & Excellent & 67.1 \\
\hline
\end{tabular}




$\begin{array}{ll}161 & \text { White oak } \\ 163 & \text { Bur oak } \\ 164 & \text { Norway maple } \\ 166 & \text { Bur oak } \\ 171 & \text { Silver maple } \\ 177 & \text { Littleleaf linden } \\ 178 & \text { Norway maple } \\ 186 & \text { Honeylocust } \\ 189 & \text { Honeylocust } \\ 218 & \text { Sugar maple } \\ 221 & \text { Littleleaf linden } \\ 225 & \text { Norway maple } \\ 231 & \text { Green ash } \\ 237 & \text { Honeylocust } \\ 246 & \text { Green ash } \\ 247 & \text { Honeylocust } \\ 248 & \text { Norway maple } \\ 249 & \text { Honeylocust } \\ 250 & \text { Norway maple } \\ 254 & \text { Red pine } \\ 264 & \text { Norway maple } \\ 266 & \text { Norway maple } \\ 272 & \text { Northern catalpa } \\ 275 & \text { Sugar maple } \\ 279 & \text { Horsechestnut } \\ 284 & \text { Eastern white pine } \\ 285 & \text { Littleleaf linden } \\ 286 & \text { Black ash } \\ 288 & \text { Eastern white pine } \\ 291 & \text { Eastern white pine } \\ 292 & \text { Bur oak } \\ 297 & \text { Norway maple } \\ 308 & \text { Red Ash } \\ 317 & \text { Red Ash } \\ 346 & \text { Siberian elm } \\ 375 & \text { Norway maple } \\ 390 & \text { Freeman maple }\end{array}$

826.82
1388.03
1452.19
817.71
950.11
551.13
472.8
408.69
158.96
436.02
944.57
994.32
249.31
137.63
1405.81
336.01
545.92
376.38
1238.63
330.64
545.5
554.6
562.1
1020.82
1285.48
127.8
1201.05
494.39
458.51
56.13
60.7
2009.59
18.11
900.79
207.9
21.03
36.87

$\begin{array}{r}566 \\ 772 \\ 273 \\ 566 \\ 411 \\ 268 \\ 273 \\ 497 \\ 497 \\ 236 \\ 268 \\ 273 \\ 135 \\ 497 \\ 549 \\ 497 \\ 430 \\ 497 \\ 273 \\ 159 \\ 430 \\ 273 \\ 498 \\ 629 \\ 386 \\ 39 \\ 268 \\ 252 \\ 151 \\ 39 \\ \hline\end{array}$

\begin{tabular}{|c|c|c|}
\hline 4 & Excellent & 74.9 \\
\hline 4 & Excellent & 80 \\
\hline 4 & Excellent & 57.9 \\
\hline 4 & Excellent & 72.9 \\
\hline 4 & Excellent & 59.9 \\
\hline 4 & Excellent & 61 \\
\hline 4 & Excellent & 46.5 \\
\hline 4 & Excellent & 49 \\
\hline 4 & Excellent & 49 \\
\hline 4 & Excellent & 38.1 \\
\hline 4 & Excellent & 52.1 \\
\hline 4 & Excellent & 50 \\
\hline 4 & Excellent & 25.9 \\
\hline 4 & Excellent & 47 \\
\hline 4 & Excellent & 61 \\
\hline 4 & Excellent & 52.1 \\
\hline 4 & Excellent & 64 \\
\hline 4 & Excellent & 56.9 \\
\hline 4 & Excellent & 57.9 \\
\hline 4 & Excellent & 32 \\
\hline 4 & Excellent & 62 \\
\hline 4 & Excellent & 49 \\
\hline 4 & Excellent & 69.1 \\
\hline 4 & Excellent & 65 \\
\hline 4 & Excellent & 65 \\
\hline 4 & Excellent & 15 \\
\hline 4 & Excellent & 58.9 \\
\hline 4 & Excellent & 41.9 \\
\hline 4 & Excellent & 22.1 \\
\hline 4 & Excellent & 15 \\
\hline 4 & Excellent & 17 \\
\hline 4 & Excellent & 71.1 \\
\hline 4 & Excellent & 7.9 \\
\hline 4 & Excellent & 47 \\
\hline 4 & Excellent & 11.9 \\
\hline 4 & Excellent & 9.9 \\
\hline 4 & Excellent & 7.1 \\
\hline
\end{tabular}




$\begin{array}{ll}394 & \text { Northern red oak } \\ 398 & \text { Silver maple } \\ 400 & \text { Red Ash } \\ 403 & \text { Red Ash } \\ 405 & \text { Freeman maple } \\ 407 & \text { Northern red oak } \\ 408 & \text { Tree of heaven } \\ 410 & \text { Freeman maple } \\ 412 & \text { Freeman maple } \\ 413 & \text { Red Ash } \\ 420 & \text { Eastern white pine } \\ 433 & \text { Eastern white pine } \\ 435 & \text { serviceberry spp } \\ 436 & \text { serviceberry spp } \\ 442 & \text { Green ash } \\ 443 & \text { Freeman maple } \\ 452 & \text { Paper birch } \\ 455 & \text { Green ash } \\ 456 & \text { Black ash } \\ 471 & \text { Bur oak } \\ 474 & \text { Black walnut } \\ 479 & \text { Littleleaf linden } \\ 480 & \text { Eastern white pine } \\ 497 & \text { Black walnut } \\ 498 & \text { Black ash } \\ 499 & \text { Green ash } \\ 511 & \text { Eastern white pine } \\ 513 & \text { Red Ash } \\ 518 & \text { Black walnut } \\ 523 & \text { Eastern white pine } \\ 526 & \text { Black walnut } \\ 541 & \text { Black walnut } \\ 559 & \text { Bur oak } \\ 560 & \text { Yellow birch } \\ 571 & \text { Northern catalpa } \\ 572 & \text { Silver maple } \\ 573 & \text { Siberian elm } \\ \end{array}$

37.89
55.3
63.52
45.64
143.43
47.1
186.02
60.13
127.86
17.58
55.08
63.57
32.37
32.37
31.67
114.86
27.25
25.71
29.91
35.46
574.29
46.19
136.32
41.66
27.85
108.77
56.7
96.54
57.98
22.5
1487.91
2668.29
24.2
89.48
244.02
288.04
46.42

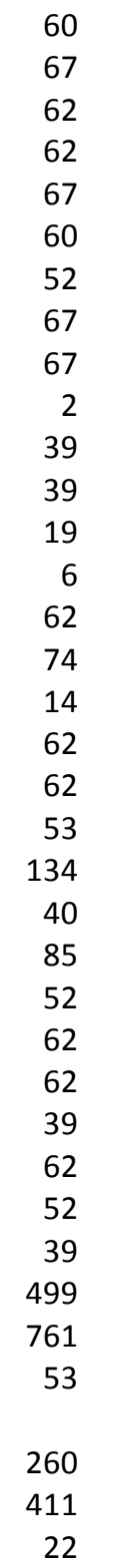

$\begin{array}{llr}4 & \text { Excellent } & 9.9 \\ 4 & \text { Excellent } & 11.2 \\ 4 & \text { Excellent } & 9.9 \\ 4 & \text { Excellent } & 7.9 \\ 4 & \text { Excellent } & 15 \\ 4 & \text { Excellent } & 9.9 \\ 4 & \text { Excellent } & 13 \\ 4 & \text { Excellent } & 7.9 \\ 4 & \text { Excellent } & 15 \\ 4 & \text { Excellent } & 6.1 \\ 4 & \text { Excellent } & 8.9 \\ 4 & \text { Excellent } & 14 \\ 4 & \text { Excellent } & 8.9 \\ 4 & \text { Excellent } & 7.3 \\ 4 & \text { Excellent } & 8.9 \\ 4 & \text { Excellent } & 11.9 \\ 4 & \text { Excellent } & 7.1 \\ 4 & \text { Excellent } & 7.9 \\ 4 & \text { Excellent } & 7.9 \\ 4 & \text { Excellent } & 8.9 \\ 4 & \text { Excellent } & 16 \\ 4 & \text { Excellent } & 10.9 \\ 4 & \text { Excellent } & 20.1 \\ 4 & \text { Excellent } & 8.9 \\ 4 & \text { Excellent } & 8.9 \\ 4 & \text { Excellent } & 13 \\ 4 & \text { Excellent } & 9.9 \\ 4 & \text { Excellent } & 13 \\ 4 & \text { Excellent } & 8.9 \\ 4 & \text { Excellent } & 7.9 \\ 4 & \text { Excellent } & 56.9 \\ 4 & \text { Excellent } & 71.1 \\ 4 & \text { Excellent } & 10.9 \\ 4 & \text { Excellent } & \text { Excellent } \\ 4 & \text { Excellent } & \\ & & 5.9 \\ 4 & \end{array}$




$\begin{aligned} 578 & \text { Black ash } \\ 585 & \text { Red Ash } \\ 591 & \text { Black walnut } \\ 594 & \text { Black walnut } \\ 595 & \text { Black walnut } \\ 614 & \text { Norway maple } \\ 11 & \text { Norway maple } \\ 25 & \text { Norway maple } \\ 29 & \text { Norway maple } \\ 45 & \text { Green ash } \\ 265 & \text { Norway maple } \\ 295 & \text { Kentucky coffeetree } \\ 314 & \text { Black walnut } \\ 325 & \text { Red Ash } \\ 326 & \text { Siberian elm } \\ 386 & \text { Eastern white pine } \\ 440 & \text { Northern red oak } \\ 453 & \text { Eastern white pine } \\ 454 & \text { Eastern white pine } \\ 564 & \text { Black ash } \\ 5 & \text { Norway maple } \\ 27 & \text { Norway maple } \\ 30 & \text { Norway maple } \\ 46 & \text { Silver maple } \\ 151 & \text { White oak } \\ 257 & \text { Norway maple } \\ 302 & \text { Norway maple } \\ 196 & \text { Norway maple } \\ 217 & \text { Norway maple } \\ 228 & \text { Red pine } \\ 256 & \text { Red pine } \\ 269 & \text { Red pine } \\ 305 & \text { London plane } \\ 318 & \text { Black walnut } \\ 328 & \text { Black walnut } \\ & \end{aligned}$

$\begin{array}{r}61.2 \\ 58.17 \\ 219.17 \\ 31.77 \\ 97.5 \\ 78.79 \\ 527.72 \\ 754.82 \\ 592.82 \\ 778.29 \\ 415.19 \\ 1624.2 \\ 64.84 \\ 52.93 \\ 122.18 \\ 61.77 \\ 31.57 \\ 11.82 \\ 12.24 \\ 49.51 \\ 552.79 \\ 541.65 \\ 921.72 \\ 445.11 \\ 594.54 \\ 529.2 \\ 2121.97 \\ 373.4 \\ 394.8 \\ 311.2 \\ 347.91 \\ 464.87 \\ 1544.89 \\ 463.62 \\ 87.14 \\ \hline\end{array}$

62
62
134
14
52
64
151
430
273
729
273
761
52
62
22
39
60
39
39
62
273
151
273
411
566
151
273
273
273
159
245
245
535
52
14

$\begin{array}{llr}4 & \text { Excellent } & 7.9 \\ 4 & \text { Excellent } & 7.9 \\ 4 & \text { Excellent } & 18 \\ 4 & \text { Excellent } & 6.1 \\ 4 & \text { Excellent } & 10.9 \\ 4 & \text { Excellent } & 16.6 \\ 4 & \text { Fair } & 38.9 \\ 4 & \text { Fair } & 61.2 \\ 4 & \text { Fair } & 55.4 \\ 4 & \text { Fair } & 88.6 \\ 4 & \text { Fair } & 46 \\ 4 & \text { Fair } & 71.9 \\ 4 & \text { Fair } & 8.9 \\ 4 & \text { Fair } & 7.9 \\ 4 & \text { Fair } & 6.1 \\ 4 & \text { Fair } & 11.9 \\ 4 & \text { Fair } & 8.9 \\ 4 & \text { Fair } & 8.9 \\ 4 & \text { Fair } & 7.9 \\ 4 & \text { Fair } & 7.9 \\ 4 & \text { Good } & 46 \\ 4 & \text { Good } & 45 \\ 4 & \text { Good } & 57.9 \\ 4 & \text { Good } & 56.1 \\ 4 & \text { Good } & 71.1 \\ 4 & \text { Good } & 36.1 \\ 4 & \text { Good } & 56.9 \\ 4 & \text { Poor } & 6.1 \\ 4 & \text { Poor } & \end{array}$




\section{References}

Akbari, H., Pomerantz, M., \& Taha, H. (2001). Cool surfaces and shade trees to reduce energy use and improve air quality in urban areas. Solar Energy, 70(3), 295-310.

Akbari, H. \& Konopacki, S. (2004). Energy Effects of Heat-Island Reduction Strategies in Toronto, Canada. Energy 29(1):191-210.

Alvey, A. A. (2006). Promoting and preserving biodiversity in the urban forest. Urban Forestry \& Urban Greening, 5(4), 195-201.

Bertin, R. I., Manner, M. E., Larrow, B. F., Cantwell, T. W., \& Berstene, E. M. (2005). Norway maple (acer platanoides) and other non-native trees in urban woodlands of central massachusetts. Journal of the Torrey Botanical Society, 132(2), 225235.

Boyce, J. (1938). Forest pathology. New York \& London: McGraw-Hill.

City of Boston. (2013). Urban forestry. Retrieved August/10, 2013, from http://www.cityofboston.gov/parks/streettrees/

City of Toronto. (2013). Urban forestry. Retrieved July/23, 2013, from http://www.toronto.ca/trees/

Chen, W. Y., \& Jim, C. Y. (2008). Assessment, and valuation of the ecosystem services provided by urban forests. in: Carreiro, M., Y. song and J. wu (eds), Ecology, Planning, and Management of Urban Forests International Perspectives, 53(1).

Dwyer, J.F., Nowak, D.J., Noble, M.H., Sisinni, S.M., (2000). Connecting people with ecosystems in the 21st century, an assessment of our nation's urban forests. General Technical Report, PNW-GTR-490. USDA Forest Service, Pacific Northwest Research Station, Portland OR, p. 483.

Frelich, L. E. (1992). Predicting dimensional relationships for twin cities shade trees. University of Minnesota - Twin Cities

Girod, B., Wiek, A., Mieg, H., \& Hulme, M. (2009). The evolution of the IPCC's emissions scenarios. Environmental Science \& Policy, 12(2), 103-118.

Gómez-Baggethun, E., \& Barton, D. N. (2013). Classifying and valuing ecosystem services for urban planning. Ecological Economics, 86, 235-245. 
Grapentine, L., Rochfort, Q., \& Marsalek, J. (2008). Assessing urban stormwater toxicity: Methodology evolution from point observations to longitudinal profiling. Water Science and Technology, 57(3), 1375.

GreenHere. (2013). GreenHere: Community reforestation and greening initiatives. Retrieved August/10, 2013, from http://www.greenhere.ca/index.html

Groombridge, B., \& Jenkins, M. (2002). World atlas of biodiversity earth's living resources in the 21st century. Berkley, CA: University of California Press.

Hirabayashi, S., Kroll, C., \& Nowak, D. (2012). i-tree eco dry deposition model descriptions. (Model Description No. 1.1). Syracust, NY: The Davey Tree Expert Company.

i-Tree. (2012). What is i-tree? Retrieved June/15, 2013, from http://www.itreetools.org/index.php

Jansson, M., \& Lindgren, T. (2012). A review of the concept 'management' in relation to urban landscapes and green spaces: Toward a holistic understanding. Urban Forestry \& Urban Greening, 11(2), 139-145.

Jim, C. Y., \& Liu, H. T. (2001). Species diversity of three major urban forest types in guangzhou city, china. Forest Ecology and Management, 146(133), 99.

Kenney, A., van Waessenaer, P., \& Satel, A. (2010). Sustainable urban forest management planning using criteria \& indicators. Cities and the Environment, 3(1), August 13, 2010-Poster 16.

Lawrence, A. B., Escobedo, F. J., Staudhammer, C. L., \& Zipperer, W. (2012). Analyzing growth and mortality in a subtropical urban forest ecosystem. Landscape and Urban Planning, 104(1), 85-94.

Martin, N.A., Chappelka, A., Keever, G., Loewenstein, E. (2011). A 100\% Tree inventory using i-Tree Eco protocol: a case study at Auburn University, Alabama, U.S. Arboriculture \& urban forestry, 37 (5), 207-212.

McKinney, M.L., (2006). Urbanization as a major cause of biotic homogenization. Biological Conservation 127, 247-260.

McLean, D., Ryan, J., \& Hurd, A. (2007). Seeing the urban forest through the trees: Building depth through qualitative research. Arboriculture and Urban Forestry, 33(1), 308.

McPherson, E. G., Simpson, J. R., Peper, P. J., Gardner, S. L., Vargas, K. E., Maco, S. E., \& Xiao, Q. (2006). Piedmont community tree guide: Benefits, costs, and strategic planting. ( No. PSW-GTR-200).USDA Forest Service General Technical Report. 
McPherson, G., \& Peper, P. (2012). Urban tree growth modeling. Arboriculture and Urban Forestry, 38(5), 172-180.

McPherson, G., Simpson, J. R., Peper, P. J., Maco, S., \& Xiao, Q. (2005). Municipal forest benefits and costs in five US cities Journal of Forestry, 103(8), 411-416.

McPherson, E. G. (1999). In Simpson J. R., Pacific Southwest Research Station (Eds.), Carbon dioxide reduction through urban forestry: Guidelines for professional and volunteer tree planters. Albany, Calif.: U.S. Dept. of Agriculture, Forest Service, Pacific Southwest Research Station.

Millward, A. A., \& Sabir, S. (2010). Structure of a forested urban park: Implications for strategic management. Journal of Environmental Management, 91(11), 22152224.

Millward, A. A., \& Sabir, S. (2011). Benefits of a forested urban park: What is the value of allan gardens to the city of toronto, canada? Landscape and Urban Planning, 100(3), 177-188.

Morgan, G., 1991. A Strategic Approach to the Planning and Management of Parks and Open Spaces. The Institute of Leisure \& Amenity Management, Berkshire.

Morrison, H. J. (2008). Land cover distribution and change in toronto, ontario, canada from 1985-2005. (Unpublished Master of Spatial Analysis). Ryerson University,

Nakicenovic, N., Alcamo, J., Davis, G., de Vries, B., Fenhann, J., Gaffin, S., Dadi, Z. (2000). Special report on emission scenerios . (Special Report No. 1). Cambridge, United Kingdom: Intergovernmental Panel on Climate Change. . (IPCC Special Report)

Nikoofard, S., Ugursal., V. I., \& Beausoleil-Morrison, I. (2011). Effect of external shading on household energy requirement for heating and cooling in canada. Energy \& Buildings, 43(7), 1627-1635.

Nowak, D. J., Kuroda, M., \& Crane, D. E. (2004). Tree mortality rates and tree population projections in baltimore, maryland, USA. Urban Forestry \& Urban Greening, 2(3), 139-147.

Nowak, D. J., \& Walton, J. (2006). Projected urban growth (2000-2050) and its estimated impact on the US forest resource Journal of Forestry, 103(8), 383.

Nowak, D. J. (2012). Contrasting natural regeneration and tree planting in fourteen north american cities. Urban Forestry \& Urban Greening, 11(4), 374-382. 
Nowak, D. J., \& Crane, D. E. (2002). Carbon storage and sequestration by urban trees in the USA. Environmental Pollution, 116(3), 381-389.

Nowak, D. J., Greenfield, E. J., Hoehn, R. E., \& Lapoint, E. (2013). Carbon storage and sequestration by trees in urban and community areas of the united states. Environmental Pollution, 178(7), 229-236.

Pachauri, R., \& Reisinger, A. (2007). Climate change 2007: Synthesis report. contribution of working groups I, II and III to the fourth assessment report of the intergovernmental panel on climate change. (No. 4). Geneva, Switzerland: Intergovernmental Panel of Climate Change. Retrieved from http://www.ipcc.ch/pdf/assessment-report/ar4/syr/ar4_syr.pdf

Peper, P., McPherson, G., \& Mori, S. (2001). Predictive equations for dimensions and leaf area of coastal southern california street trees. Journal of Arboriculture 27(4): July 2001, 27(4), 169.

Peper, P., McPherson, G., \& Mori, S. (2001b). Equations for predicting diameter, height, crown width and leaf area of san joaquin valley street trees. Journal of Arboriculture 27(4): July 2001, 27(4), 169.

Peper, P. J., \& McPherson, E. G. (2003). Evaluation of four methods for estimating leaf area of isolated trees. Urban Forestry \& Urban Greening, 2(1), 19-29.

Puppim de Oliveira, J. A., Balaban, O., Doll, C. N. H., Moreno-Peñaranda, R., Gasparatos, A., lossifova, D., \& Suwa, A. (2011). Cities and biodiversity: Perspectives and governance challenges for implementing the convention on biological diversity (CBD) at the city level. Biological Conservation, 144(5), 13021313.

Randrup, T. B., \& Persson, B. (2009). Public green spaces in the nordic countries: Development of a new strategic management regime. Urban Forestry \& Urban Greening, 8(1), 31-40.

Roloff, A., Korn, S., \& Gillner, S. (2009). The climate-species-matrix to select tree species for urban habitats considering climate change. Urban Forestry \& Urban Greening, 8(4), 295.

Sawka, M., Millward, A. A., Mckay, J., \& Sarkovich, M. (2013). Growing summer energy conservation through residential tree planting. Landscape and Urban Planning, 113, 1-9.

Semenzato, P., Cattaneo, D., \& Dainese, M. (2011). Growth prediction for five tree species in an italian urban forest. Urban Forestry \& Urban Greening, 10(3), 169176. 
Seto, K. C., Sánchez-Rodríguez, R., \& Fragkias, M. (2010). The new geography of contemporary urbanization and the environment. Annual Review of Environment and Resources, 35(1), 167-194.

Tait, C.J., Daniels, C.B., Hill, R.S., (2005). Changes in species assemblages within the Adelaide metropolitan area, Australia,1836-2002. Ecological Applications 15(2), 346-359.

Troxel, B., Piana, M., Ashton, M. S., \& Murphy-Dunning, C. (2013). Relationships between bole and crown size for young urban trees in the northeastern USA. Urban Forestry \& Urban Greening, 12(2), 144-153.

Webster, C. R., Nelson, K., \& Wangen, S. R. (2005). Stand dynamics of an insular population of an invasive tree, acer platanoides. Forest Ecology and Management, 208(1-3), 85-99.

Welch, J. M. (1994). Street and park trees of boston: A comparison of urban forest structure. Landscape and Urban Planning, 29(2-3), 131-143.

White, M. A., Running, S. W., \& Thornton, P. E. (1999). The impact of growing-season length variability on carbon assimilation and evapotranspiration over 88 years in the eastern US deciduous forest. International Journal of Biometeorology, 42(3), 139-145. 